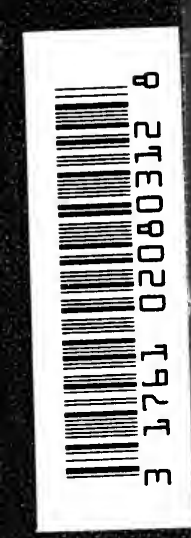




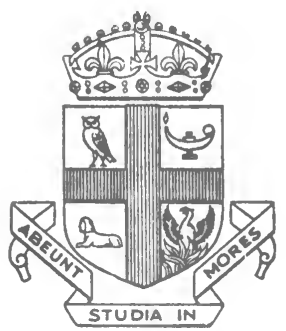

THE LIBRARY

of

VICTORIA UNIVERSITY

Toronto 


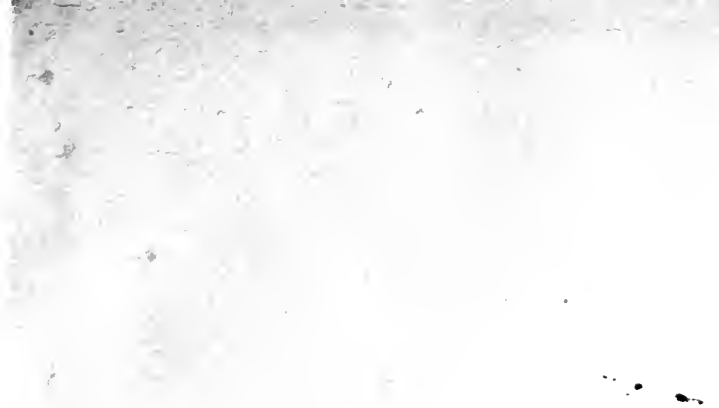

1. $x^{3}$

$=\frac{4}{1}$

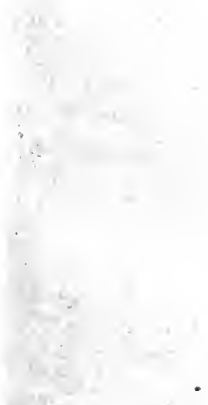





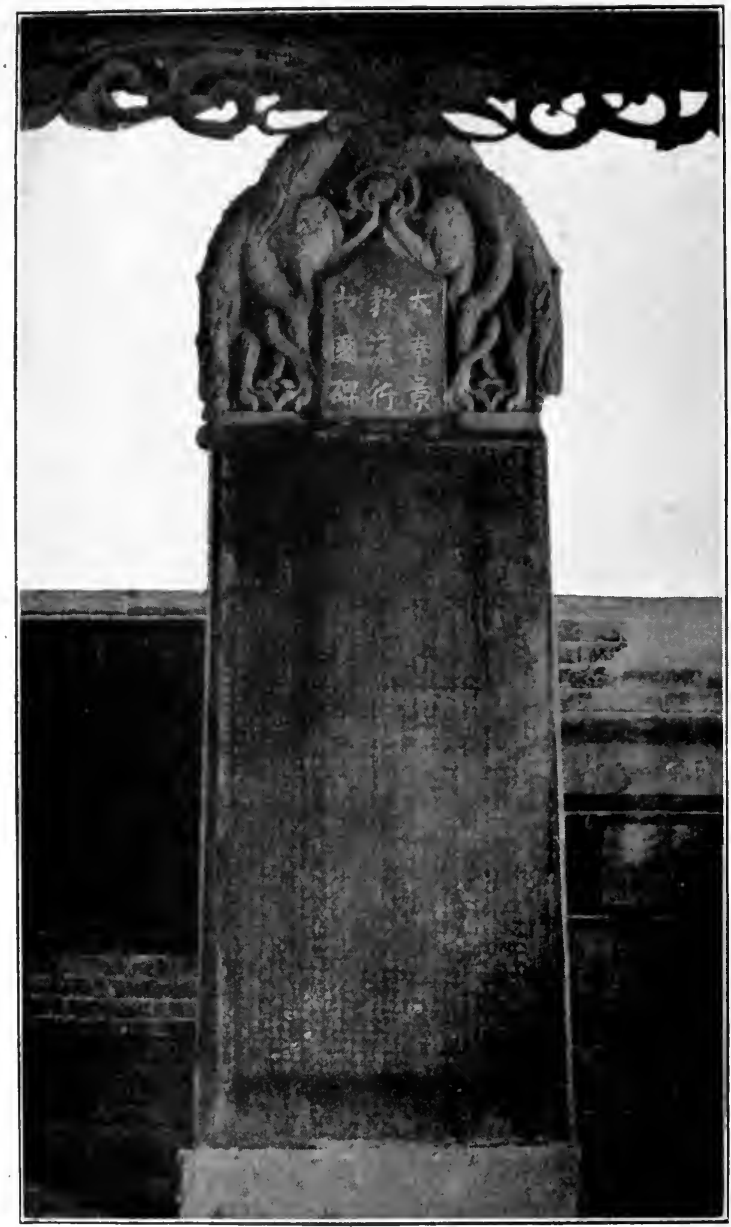

THE "NESTORIAN MONUMENT" IN THE PEI LIN AT IISI-AN $\mathrm{TU}$.

(From Holm's "Nestorian Monument.")

[Frontispiece. 


\title{
THE
}

\section{NESTORIAN MONUMENT IN CHINA}

\author{
BY \\ P. Y. SAEKI \\ PROFESSOR AT THE WASEDA UNIVERSITY \\ TOKYO
}

\begin{abstract}
WITH AN INTRODUCTORY NOTE BY LORD WILLIAM GASCOYNE-CECIL AND
\end{abstract}

A PREFACE BY THE

REV. PROFESSOR A. H. SAYCE

LONDON

SOCIETY FOR PROMOTING C H R IS T A N K OWLED GE NEW YORK AND TORONTO: THE MACMILLAN CO. 


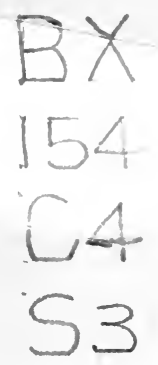

EMMANUEL
First PUblished - igi6
Reprinted -

PRINTED IN GREAT BRITAIN BY

RILLING AND SONS LTD., GUILDFORD AND ESHER 


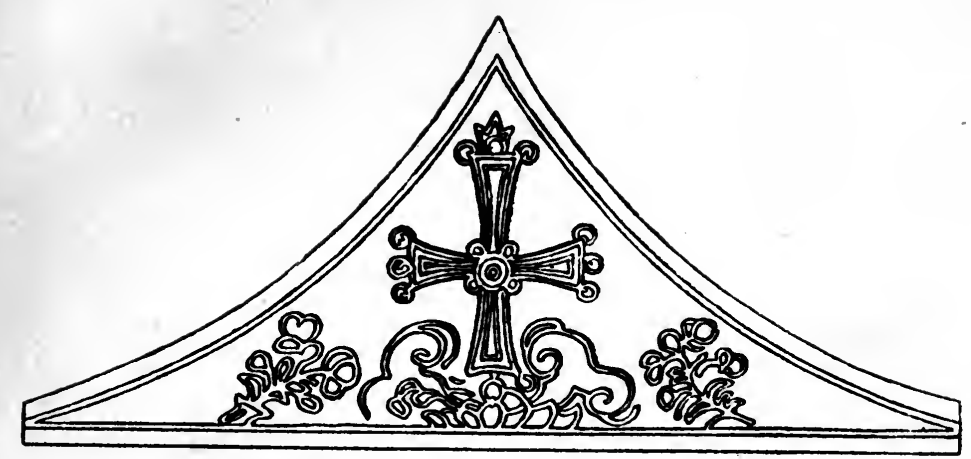

THE CROSS ON THE NESTORIAN MONUMENT. (From Holn's "Nestorian Monument.")

\section{LIST OF ILLUSTRATIONS}

The "Nestorian Monument" in the PEI LIV at Hsi-an Fu (From Holu's "Nestorian Monument.")

TO FACE PAGE Frontispiece

ONe of The Gates of HSI-AN Fu

(From Halm's "Nestorian Monument," p. 30.)

Frontispiece

Japanese fan, showing a Phrygian Cap

$\cdots \quad \cdots \quad \cdots \quad 39$

Pieces of Incense-Wood

$\cdots \quad \cdots \quad \cdots$

$\cdots$

$\cdots \quad 45$

Specimens of the "Honeysuckle" Pattern from Japanese

$\begin{array}{llllll}(1-6) & \text { ANd ChINESE (7-12) BuIldings } & \ldots & \ldots & \ldots & 63\end{array}$

The Cross and Title of the "Nestorian Monument" $\quad \ldots \quad 162$

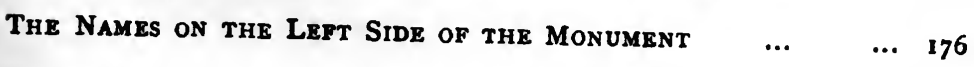

The Names on the Right Side of the Monument $\quad \ldots \quad$.. 180 



\section{INTRODUCTORY NOTE}

IT is with the greatest pleasure that I recommend this book. It opens up a new view of the origin of much of the Far Eastern civilisation. Undoubtedly that civilisation has been largely effected by the Mahayana Buddhism, and that Buddhism has always been acknowledged to have had close relations to Christian teaching, but the exact path whereby some of the Christian atmosphere has permeated Eastern civilisation has never been so clearly traced before. The Western reader, while he must remember that the book is written from an Eastern point of view, will find much to interest him. Apparently the mistake made by the Nestorian preachers was that of being ashamed of their faith, and trying to recommend it merely as a branch of Buddhism. There is always a temptation, and always a danger in Mission work, to soften down the edges of our faith, to represent it as something not so very new, not so very different from what is already known; such a policy may avoid immediate difficulties, but afterwards it tends towards defeat ; the Christianity which has conquered has been that which is urged with distinctness even amounting to harshness. It seems as if the compromising nature of Nestorianism was the reason why, when Buddhism fell, it was entangled in that fall and then forgotten.

Perhaps we may not agree with all the Author says about Nestorianism, but the reader must remember the book is written from an Eastern, not a Western point of view, and 
that Professor Saeki does not write to elucidate an ancient heresy, but to show the influence Christianity had on the Ch'ang-an civilisation.

It is no exaggeration to say that the erudition of the Author has given to the world a work of the greatest importance, which will be valued by all scholars and students, and one which should also prove of great interest to the general reader. 


\section{PREFACE}

Professor SAekI's elaborate and interesting book on "The Nestorian Monument in China," is one of the most important works ever written upon the history of the introduction of Christianity into the Far East, and of the still-abiding influence of that early Christianity in the religious thought of China and Japan. It is the work of a Japanese scholar who, it is needless to say, is able to understand and sympathise with Chinese thought, speech and literature, in a way that no European scholar can ever hope to do, and who at the same time is thoroughly acquainted with the latest results of European scholarship and criticism. The famous monument of the early Christian Church at Hsi-an-fu in Western China has found in him a devoted and enthusiastic interpreter, and for the first time the story it has to tell is fully revealed to us.

Nothing bearing upon the subject has been overlooked, and the book is full of new light as well as of new facts. Indeed, a considerable proportion of the facts contained in it will be new to most of its readers, who will be surprised to learn that there was a time when it seemed possible that Christianity would be the state religion of the Chinese Empire. The most brilliant period in the history of China was that when the country was governed by the T'ang Dynasty (A.D. 618-906), and it was at the beginning of this period that the first Nestorian missionaries arrived in $\mathrm{China}_{2}$ and were favourably received by the government. The Chinese were at the time singularly open to foreign influence; the terra-cotta figurines and the beautiful pottery and porcelain found in the Tang tombs, bear the marks of Hellenistic influence ; cloisonné 
work was introduced from Byzantium, and Arab traders were allowed to settle and build their mosques in the seaport towns. The culture of China was carried to Japan, where the court of the Mikado soon began to rival that of the Chinese emperor in luxury and splendour. Along with this culture went a knowledge, more or less, of Christianity, and on two of the beams from the seventh-century temple of Horyuji in Japan, which are now in the Tokyo Museum, I have copied inscriptions which are in an alphabet belonging to the same class as the Syriac and are accompanied by crosses.

One of the most interesting of Professor Saeki's suggestions is that in the Chinese secret society called Chin-tan Chiao, we have the descendants of the Chinese Nestorians. $\mathrm{He}$ is also successful in pointing out that the "Protestant" Buddhism of Japan is to be ultimately traced to Christian tradition. His book, accordingly, is not only one for the scholar and "general reader," but it is also of special importance to the ecclesiastical historian and to all who are interested in Christian missions in the Far East. It lifts the veil, as it were, from Japanese and, therewith, Chinese Buddhism, and reveals on the one hand the elements common to Christianity and Buddhism, and on the other hand the fundamental religious conceptions which have to be respected and allowed for if Christianity is ever to win over the educated populations of China and Japan.

A. H. SAYCE. 


\section{THE AUTHOR'S PREFACE}

"THE darkest place is the foot of the lamp." The Nestorian Monument in China, famous as it is in the West, is not so well and widely known in the Far East. This is strange enough but can be easily accounted for. It was only in the year 1817 that the Nestorian Inscription itself was for the first time made known to the Japanese. In that year, many books, were imported from China and among them was a book compiled by Wang Ch'ang in 1805 called " A great Collection of Inscriptions on stone and metal," which contained the famous Nestorian Inscription in the sixty-fifth volume. But the sagacious Kondo Seisai was the "Inspector-General of Publication and Imported Books," of Japan at that time. As soon as he read the Nestorian Inscription, he concluded it had something to do with "the Religion of Jesus," which was then strictly forbidden by the Shogun's law, and he consequently declared the whole book by Wang Ch'ang prohibited in Japan.

Thus it came about that nothing had ever been known about this famous Inscription in Japan until the year 1876 , when Dr. Martin's Chinese book called “ $T$ 'ien Tao Su Yüan” ("The Way of Heaven Traced to its Origin"), which contained the Nestorian Inscription, was published by the London Bible and Tract Society with the Japanese reading marks added to the Chinese text. The work was done by the famous Dr. Nakamura Keiu, the translator of Dr. Samuel Smiles's works into Japanese; but as he did not express his views on it, the Inscription still remained unstudied by Japanese scholars at large, and it is only recently 
that fresh attention has been directed to it by two of our learned men-Dr. J. Takakusu, Professor of Sanskrit and Pali at the Imperial University of Tokyo, and Dr. $H$. Kuwabara, Professor of Chinese Classics and Oriental History at the Imperial University of Kyoto.

In the year $1896 \mathrm{Dr}$. Takakusu published a very interesting and valuable article in the well-known Journal Toung Pao. $\mathrm{He}$ had discovered the name Ching-ching, Adam, the Persian priest who composed the Inscription, in the Buddhist Sûtra whilst he was associated with Professor Max Müller in Oxford in translating a certain Chino-Sanskrit work.

More than nineteen years have passed since he wrote this article, and his article, short as it is, speaks volumes as to the genuineness of the stone itself. Every work on the Nestorian Monument in China after 1897 by European as well as American scholars contains some quotations from this article of his. Indeed without reference to his work the study is not complete. But he never pushed his investigation further, or at least he did not publish the result of his investigation as he promised at the end of his T'oung Pao article.

On the other hand, Dr. Kuwabara saw the very stone at the very spot a few years ago. He published his opinion on the stone in the Gei-Bun, the organ belonging to the College of Literature of the Imperial University of Kyoto. As he is so well versed in Chinese literature and history, it goes without saying that his descriptions of the Monument and his observations on the Inscription are very valuable, whilst his bibliography is complete. But to our great disappointment he, too, did not go beyond the external description of the Monument. From the nature of the work he intended to do in his article perhaps he wished to avoid entering into the textual criticism of the Inscription.

Far be it from the author to claim that he has filled the gap left by these two learned friends of his. On the contrary, the author cannot but express his indebtedness to 
them and to their articles, and also to the interesting article "On Kobo Daishi and the Nestorians in China," by the Hon. Mrs. E. A. Gordon, who set up the replica of the Nestorian Monument at the top of Mount Koya-the holy land of Japan, on the 3rd of October, I9II. The author may well say, therefore, that his book, small as it is, contains all the leading thoughts that have been expressed about the Nestorian Monument either by the Japanese or in Japan, and at the same time not a little from valuable hints and suggestions on the Nestorian Stone in the words of such great scholars as Mr. Alexander Wylie, Dr. James Legge, Father H. Havret, Dr. Heller and many others.

Many valuable hints and suggestions also have been received from Dr. D. S. Margoliouth, Professor of the Syriac Language and Literature at Uxford; Mrs. Margoliouth; Mr. Philip Dodge, and others. The author feels an unspeakable debt of gratitude to the Hon. Mrs. E. A. Gordon, the authoress of the "World's Healer," who helped him from beginning to end most disinterestedly. Indeed, but for her kind help and encouragement the work would have been impossible.

Lastly-but not the least-the author expresses his hearty thanks to Professor A. H. Sayce, whose kind words of sympathy and encouragement from time to time helped the author to pass through the field of drudgery and by whose valued intervention the publication of the book in England was secured. It is a great pleasure for any author to have a preface by Professor Sayce to get his book chaperoned in England, where, as we are told, people do not speak to each other unless they are properly introduced. How much more then should the present author appreciate a great service of kindpess rendered to him by the great professor of the English University whose name is so very widely known!

If the book rouses in any way interest on the famous Inscription and serves to encourage the study of the relation 
between Mahayana Buddhism and Nestorianism in China, credit is mainly due to those persons who kindly helped the author directly and indirectly. For the shortcomings and failures of this book the author is alone responsible, and sincerely begs lenient overlooking of them on the ground that this is the first book in which the whole subject has been treated in English by a Japanese.

P. Y. SAEKI.

The Waseda University, Tokyo,

Sept. 15th, 1913. 


\section{THE NESTORIAN MONUMENT IN CHINA}

PART I.

\section{INTRODUCTION.}

THE NESTORIAN Stone with its famous Inscription, which we The

Nestorian. are now about to study, is the means wherewith Monument as to reveal the past relationship between the East material for Worldhistory. and the West which was buried in the clouds of the Dark ages. It furnishes a light by which we may retrace the old route between China and the Roman Orient that has for so leng been obscure Its study-which may be likened to that of the "Rosetta Stone" or "Rock of Behistun "-is destined to throw an abundant light on the character of Chinese civilization in High Asia during the Middle Ages of our Era.

It is by means of this stone that we are enabled to ascertain the reason why we encounter some European elements in the Ch'ang-an civilization - a civilization so exquisitely high as to place even that of Rome in the shade. Through it we can at once grasp the idea of the position held by Assyrian Christianity among,st Buddhists, Confucianists, Taoists, Zoroastrians, and Mohammedans in the seventh, eighth, and ninth centuries A.D.

Studying this inscription carefully we can clearly see how severe the religious struggle for existence was, and in what a difficult position the Nestorian missionaries found themselves, in spite of the favour and recognition they received from the reigning sovereigns of China. In short, it is only by 
studying this Monument that we can decide how far the Ch'ang-an civilization was a Christian one.

"Only a stone!" I hear some one exclaim. Yes! but "the very stones shall cry out" if we men fail to do so. "Only a stone!" but this one has been preserved by the Divine Providence to reveal to us the true condition of the spiritual side of the T'ang Era, which lasted for some three. hundred years (618-907 A.D.).

It is a picture of Chinese thought. It brings to light the background of the Ch'ang-an civilization which influenced the neighbouring countries of High Asia ; and possibly it will illuminate the origin of the Chin-tan Chiao (金丹教), a strong Secret Society, which claims the immense number of I I, 000,000 adherents, and also that of Mohammedans, $21,000,000$ of whom are said to be found in China to-day.*

Besides, the stone is actually the great torch which reveals the nature of the civilization which the Japanese received from the Asiatic Continent as the result of their intercourse with China during the $T$ 'ang Dynasty. Hence the study of the inscription is too important a subject to leave entirely in the hands of archæologists.

It should be studied not only by those who take interest in so-called Missionary work, but by University scholars, as well as by practical statesmen.

China is the greatest problem of the twentieth century, and for those who desire to study China there is no better initiation than the study of this wonderful historic stone!

At present, this famous stone can be seen at Hsi-an-fu The (西安 府), the greatest and most historic city Nestorian Monument, where can it be seen? of all China. The name of no other place in the Far East has been so differently pronounced as that of this ancient capital. It has been spelled Hsi-an; Si-an ; Si-gan; Sengan; Si-ngan ; Hsingan. Even in conservative China the name of the city has experienced 
frequent alteration. It had been Ching-chao yin (京兆尹); Yung-chou (Ching-chao) (雍州)(京光); Shang-tu (Chingchao-fu) (上都)(京兆府). It was during the Ming Dynasty that the city was for the first time denominated Hsi-ani-fu.

Strange to say, the modern prefectural city of Hsi-an-fu -which is the seat of the provincial government-really consists of two district cities-Ch'ang-an hsien and Hsienning hsien-within the same walls, the former occupying the western, the latter the eastern section. This modern Hsi-an-fu is better known in history as Ch'ang-an, the name now applied exclusively to the district in which part of the city stands.

The history of Ch'ang-an is really a history of the Chinese Empire dating from its earliest period. It was already in existence in 2205 B.C., and was known then as "the Wellwatered City" (豐水). It was the capital of the Chou Dynasty (周) (1122-255 B.C.). About twenty miles northwest of the present site another capital was founded by Hsien, King of Chou (周 顯王), under the name of Hsienyang (成陽) in 350 B.C. This was, however, given up in 207 B.C., with the downfall of the Ch'in Dynasty, which had succeeded the Chou in 255 B.c. The famous A-fang-kung (阿房宮), the Chinese “Temple of Bel," stood about halfway between the present sites of Hsien-yang and Hsi-an-fu.

With the rise of the Han Dynasty (漢) in 206 B.C., another new seat of the Imperial Government was founded by Liu Pang (飳邦), the founder of the dynasty, who is commonly known as the Kao-Tsu of Han (漢高祖). The new city, together with its walls and forts, was completed in 190 B.C., and was called Ch'ang-an (長安城) (i.e. Longpeace), and has ever since been known by that name.

When the usurper Wang Mang (王芬) (9 A.D.-25 A.D:) set up his own capital Lo-yang (洛陽), further down the Huang-ho (黃河, the Yellow River) in 12 A.D., and called 
it the "Eastern Capital," the older city, Ch'ang-an, still remained as the "Western Capital."

The founder of the Eastern Han Dynasty again made "the Western Capital" the seat of his government in 24 A.D., and so it remained until 220 A.D., when the Empire was divided into "the Three Kingdoms"-Minor or Shu Han (蜀), Wei (魏) and Wu (吳). Each kingdom, of course, had its own capital in different parts of China, and Ch'ang-an, the ancient capital itself, was abandoned.

But the glory of the old city was soon again to be revived. It was made the capital of all China in 589 A.D., when the Sui Dynasty (隋) began to rule over the reunited country.

In 6r8 A.D., when the $T$ 'ang Dynasty came into power, Ch'ang-an began to realize its most glorious time. It occupled the position in the Asiatic Continent during the seventh, eighth, and ninth centuries which Madrid occupied in Europe during the fourteenth and fifteenth centuries. Its splendour was proverbial for many centuries. In fact, it remained the finest city in the Far East until 960 A.D., when the Sung Dynasty (宋) arose out of the ruins of the T'ang Dynasty and once more changed the capital from Hsi-an-fu to Pienliang (沛梁).

Thus Hsi-an remained the capital of China during five out of nineteen dynasties, or for over ten of the over thirty centuries of its existence. It was the greatest city in the Far East and is the most historic in all China. But the site and size of the city have not been one and the same at all times. The size; especially, has varied with the ups and downs of the reigning dynasty. In its most glorious time it covered about thirty square miles, while in its evil days it occupied only four and a half square miles.

In the book called “Ch'ang-an Topography” (長安志) written by Sung Min-ch'iu (来敏求) in ro79 A.D., he remarks that "the city itself is 13 li (i.e. 5 miles) square." 
$=$ 


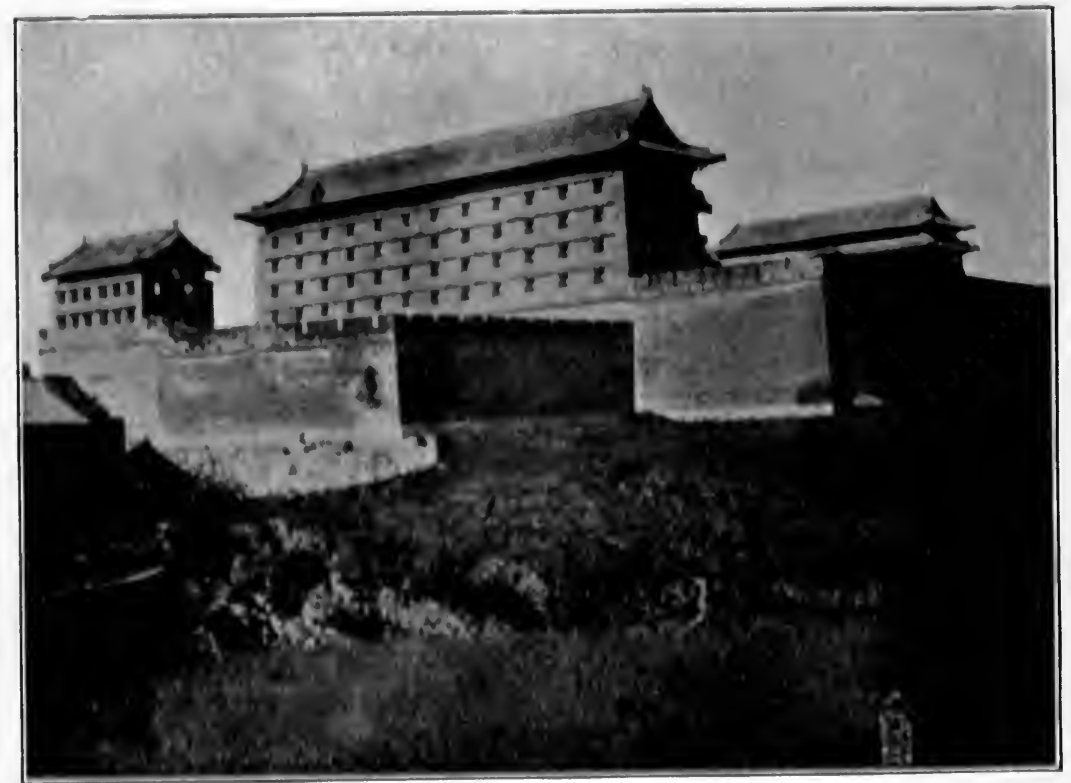

ONE OF THE GATES OF HSI-AN FU.

(Lrom Holm's "Nestorian Monument," p. 30.)

[To firce $p \cdot 5$. 
(長安城東西十三里南北十三里). The number of the postal-station towns of China in the T'ang Era is said to have been 1639 in all. "All the roads lead to Ch'ang-an," and 47 of these postal-station towns were within 100 miles from the Royal city. They were all good, thriving towns when Ch'ang-an was a flourishing capital. But with the downfall of the T'ang Dynasty its glory departed, and the attached towns and suburb-villages declined.

The present city was thus correctly described by Mr. C. F. Hogg, a great authority on Chinese topography :

"Calculating that something more than half an hour's brisk walking will take one through the city from East to west, we are safe in saying that the circumvallation measures certainly not more than ten miles. The city lies in the shape of a parallelogram, the distance between East and West being considerably greater than that of North and South."

Now this is the exact outline of our city of Kyoto in Japan, which, we are told, was laid out after the pattern of that famous capital Ch'ang-an or Hsi-an-ful As Hsi-an was designated with two Chinese characters denoting the "Western capital" or "West pacified," so in old days was Kyoto, which even now is known as the "Western Capital" (Saikyo).

The only difference between Kyoto and Ch'ang-an is that the Chinese capital was surrounded on all sides by immense stone walls some 30 feet high, with towers on the gateways which are much higher still, whilst the ancient Japanese capital was not walled in the same way as the Chinese city, although it had its walls and as many gates as Hsi-an-fu16 outer and 9 inner-each of which bore a similar name to that of those gates in the Chinese capital.

The location of Hsi-an-fu is $109^{\circ} 30^{\prime}$ longitude and $34^{\circ} 17^{\prime}$ North latitude. It stands in the district not far from the 
place where the Wei and the Ching (渭 水. 涇水) flow into the Yellow River. Being the terminus of the great caravan-roads throughout Asia, it was really a reservoir into which anything and everything from those outside countries which were commonly known as "Western Regions" lying beyond the desert and the prairies were gathered and from which, in turn, ampler currents of Oriental history have flowed.

In the eastern part of Hsi-an-fu, which is known as Hsienning (咸 受), there is a place called “Pei-lin”(碑林) which means the "Forest of Tablets," where the Chinese keep not only all the precious stone monuments of the city and its neighbourhood, but also some from other cities. Since October 2, 1907, our famous monument has lain in the Pei-lin, well protected from wind and rain as well as from the mischievous hands of children.

Dr. Kuwabara, Professor of Chinese classics and Oriental What is the Monument like?

History in the Imperial University of Kyoto, who saw the stone standing on its old site in the backyard of the temple ground, and by a fortunate chance witnessed its actual removal to the Pei-lin "Forest of Tablets" for preservation, thus describes it:

"In the autumn of 1907 A.D., intending to make an excursion to Hsi-an-fu and its neighbouring places of renown, we left Peking for Hsi-an on the 3rd of September. After spending sixteen days on the way, we finally reached Hsi-an$\mathrm{fu}$ on the Igth of the same month. And spending a week in the ancient capital for sight-seeing and investigating many things in connection with our historical studies there, we finally went to the Chin-shêng-ssŭ (金勝 寺), the Buddhist temple, behind which the famous Nestorian Stone stood.

"This Chin-shêng-ssŭ temple stands at a place a little more than a mile outside the Western Gate of the city. Ch'ung-shêng-ssŭ (崇聖寺) was the name by which the temple was known in the tenth and twelfth centuries, whilst 
Ch'ung-jên-ssŭ (崇仁寺) was the name given to it during the Ming Dynasty (1368-1664 A.D.) as well as in the Manchu Dynasty (1662-I9II). But Chin-shêng-ssŭ (金勝寺) is the common name for it.

"The building was burned down in 1862 A.D. during the Mohammedan trouble and nothing left but a heap of ruins. The old site and the remaining stones of the temple, however. speak volumes for its former glory, the site itself covering more than two acres of ground.

"The present temple is quite new, being recently built, and is very poor and unworthy indeed. But behind this temple there is a ruined stone gateway built in 1584 A.D., inscribed with the four Chinese characters Ch'i-yüan-chênching (祇園戛境), which means ' the best of the Garden that was dedicated to Sakyamuni.'

"Not far from this ruin and standing almost opposite it, there are several monuments erected during the Ch'ĉng-hua (1404-1487) and Chia-ching (1522-1566) periods of the Ming Dynasty. They all record the past history of the temple.

"Behind the stone gateway and to the North of it we see, some sixty yards ahead, five comparatively large stones standing in a row. The second monument from the East is the famous Nestorian Stone! The rest are all monuments that were set up after 1738 A.D.

- "The Nestorian Monument has no shelter. It is not protected at all from wind and rain as well as against mischievous human hands. Two days after we saw this famous Monument, we left the city for a week's trip to the northern part of the country. We returned to the city again on the $4^{\text {th }}$ of October. On entering the Western Gate that day, we met a body of coolies carrying a big foundation stone shaped like a tortoise towards the centre of the city. The stone was not unfamiliar to us, but we were in a hurry to return to our hotel, and did not stop to make any enquiries about it. 
"That night, however, we had a visit from a Japanese professor in connection with the Hsi-an-fu school. He told us that there had been a rumour that a certain foreigner had arrived in the city and had tried to buy the famous stone for a sum of 3,000 taels in order that he might sell it to the British Museum, and that this rumour had so startled the Governor of the Province of Shenshi, that he had ordered the Nestorian Monument to be carried to the Pei-lin, Forest of Tablets, and forbidden any one without the permission of the proper authorities even to take a rubbing of it.

"Hearing this, we concluded that the tortoise-shaped foundation stone we had seen being carried into the city through the Western Gate a few hours before must have been the very stone, and we finally decided to visit the back yard of the Chin-shêng-ssŭ temple the following morning, that is to say, on the 5th of October. We did so, and found (as we expected) that the stone had gone from its old site where it had stood for so many years ever since its excavation in 1623 A.D.

"We were rather glad to find this, because the stone thus carried into the Pei-lin is now under the protection of the Chinese authorities. We left Hsi-an-fu on the gth of October for Peking. In the afternoon of the I2th of the same month, we halted at Fu-shui-chên (數水鎮), and there we chanced to observe a very large cart passing by. It was, no doubt, constructed with a special purpose to carry something very heavy.

"It was drawn by seven or eight horses, which had very great (unspeakable) difficulty with the weight of their heavy load, owing to the bad state of the road after the rain. On enquiring what it might be, the chief coolie replied that they were carrying a Monument newly made at Hsi-an-fu down to Chêng-chou (鄭 州). Then we could not but remember what we had seen and heard at Hsi-an-fu!

"We were curious enough to wish to peep at this 
Monument. But owing to the incessant rain which had previously fallen, the road was too muddy to examine it, even if the stone had not ben so well packed that there was no telling whether it was even a newly made one, as the coolie professed it to be, or not!

"With much regret we left the stone and the coolies; and arrived at Peking on the 20th of October. In January, 1908, we received a letter from our friend and fellow-traveller Prof. T. Uno, together with a copy of 'the Han-kow Daily News,' in which we found that the foreigner referred to above was no other than Dr. Frits Holm, a Danish journalist; and that our visit to Hsi-an-fu was at the very time when Dr. Frits Holm was doing his best to get the replica after failing to purchase the original stone."

It will interest our readers to compare Prof. KuwaThe Replica bara's account of the stone and its replica of the Monument in with Dr. Frits Holm's own description. He New York. says :-

"On the Ioth of June, 1907, I first visited the restingplace of the unique Monument. I went out alone on horseback through the West Gate, traversed the western suburb, and, having passed some military barracks outside the western suburb gate, had no difficulty in finding the old Buddhist temple, on the premises of which the stone is situated. A large brick entrance in ruin and some remnants of a decayed loess wall show the former large extent of the temple. But to-day we only find a comparatively modern centre building which is more of a farm-house than of a temple. Behind this farm temple is a piece of ground where a large stone arch and several memorial slabs are situated. In a row of five stones, the Ching-chiao-pei (i.e. the Luminous Religion Monument) is the fourth, counting towards the East (Prof. Kuwabara says 'the second counting from the East'). Like most stones of a similar kind it stands on the back of a clumsily worked stone-tortoise, but nothing is left of 
a protecting shed, and nothing indicates, as some authors most wrongly. assert, that the stone and its neighbours, which do not even stand in a straight line, have ever been built into a brick wall. But there is no trace of any niche around the tablet, nor of any later wooden shed, and the 74 years old chief Priest, who has been constantly on the spot for over 50 years, only remembers the stone standing free and frank and lonely-looking apart from the ramshackle of 1891 .

"The Monument is ten feet high, its weight being two tons. The difficulties in connection with the transport of the original or a replica were consequently appalling, as it would be necessary to transport the stone on a specially constructed cart over 350 miles to the nearest railway station, Chêng-chou (奂讯州).

"I may briefly mention that I did everything in my power to obtain the original by applying to the local authorities in an indirect manner, etc.; but although the Chinese do not care more to-day for the stone than for any ordinary brick, they at once got suspicious; and I might as well have endeavoured to lift the Rosetta Stone out of the British Museum, or take the Moabite Stone from the Louvre, as to carry away the Ching-chiao-pei from Hsi-an!

"I shall not dwell here on the almost insurmountable difficulties the officials and even some of the foreign missionaries laid in my way when I decided to confine my efforts to obtain and carry home to Europe or America a replica of the venerable Tablet. Suffice it to say that both the local, the transport, and, eventually, the Customs' difficulties were all overcome in due course, and after eleven months on Chinese soil, I was able to leave Shanghai on the last day of February, 1908, bound for New York.

"This replica is one of the most beautiful pieces of Chinese workmanship I have ever seen. In the first place, there is not a measure, not a character, not a detail that 
differs from the original Tablet-even the weight is the same. In the second place, this piece of art was executed by four native stone-cutters in eleven days, including polishing after the huge slabs had been brought from the Fu-p'ing quarries to Hsi-an. In the third place, the Chinese artisans have been able to accomplish the miracle of carving the Cross and chiselling the Syriac characters, which they did not of course know, to absolute perfection.

"On the 16th of June, 1908, in accordance with the arrangement with Sir Purdon Clarke, Director, the replica was deposited in the Metropolitan Museum of Art in the City of New York, as a loan.

"Although the replica is not yet the property of the Museum, there is a probability that it will never leave its new abode again; but the fact should not be overlooked that all the museums and universities of the world can now be supplied, if so desired, with plaster casts of the Nestorian tablet, casts which would not be more accurate had they been taken from the original itself."

In 1909, when Prof. Y. Okakura went to New York, he examined Mr. Holm's replica in the Central Museum and found, to his satisfaction, that it was a very good replica indeed.

So much for the first replica that was made. Now let us Another say a few words about the "second replica in the Replica in world" which stands to-day at the top of Mt. Japan. Koya-the Holy Land of Japan.

To explain why the replica was set up there on the 21st of September, 1911, we must ask the reader to accompany us from Hsi-an-fu to Mt. Koya, where the famous Kobo Daishi, "the Great Teacher of the Law," opened the monastery of Kongo-buji in the year 816 A.D.

This famous monastery belongs to a sect known as Shingonshu (黄言宗), which means the “True-WordReligion." 
Being numerically the strongest in Japan-the membership of this Buddhist sect numbering a little over $17,538,000$ (the Shinshu sect has 13,325,619)-the erection of this replica is very full of promise, for every year half a million Pilgrims of all ages and classes and from all parts of Japan climb the Holy Mountain to visit the tomb of Kobo Daishi in the Okunc-in, so that the stone is sure to speak aloud and strongly in God's due time!

It was dedicated, with full Buddhist ceremonial, on Sunday, Oct. 3 rd, I9II, and is an exact copy of the original stone. It stands just within the entrance to the wonderful cemetery of the Okuno-in, where tens of thousands of the Japanese, from Emperors to peasants, have been laid to rest in expectation of the Coming of Miroku-the expected Messiah of the Buddhists-during the 1100 years since their beloved and venerated saint Kobo Daishi returned from Ch'ang-an, where he is supposed to have seen that "Speaking Stone" which the Nestorian Monks had erected there only 23 years before his arrival.

The Nestorian Tablet is just over 9 feet in height by The Descrip. $3 \frac{1}{3}$ feet in width, and a little under a foot thick. tlon of the It was no doubt hewn out of the celebrated stone Original

Stone. quarries of Fu-p'ing-hsien.

"The material is a black, sub-granular oolitic limestone (with small oolites scattered through it), probably dating from the Carboniferous formation of some 15 or 20 millions of years ago."

The figure-head decoration of the Tablet consists of an immense pearl between two creatures called "Kumbhira," which Dr. Eitel describes as "a monster with the body of a fish, but shaped like a snake and carrying pearls in its tail "; but others say that it was a four-footed crocodile, over 20 feet long.

Now "pear:" is called "hoshu " or "tama" in Japanese, and in Sanscrit chindamani-the incarnation of all the 
principles of prayer.* But here we are sure that the pearl symbol has the regular Nestorian significance. We read in the "East Syrian Daily Offices," by Arthur John Maclean :-

"O illustrious martyr, Mar Sergius! A pearl without flaw. A light hath shone in thy soul: thou hast bought it with thy blood, and become rich thereby" (p. 46).

"The Athletes saw a pearl without flaw on the top of Golgotha " (p. 48).

"And, as by a bridge, they crossed the sea of the world by the Cross. To Eden (the high pearl), which is their dwelling" (p. 124).

"My mind wondered at the blessed company of athletes, the famous martyrs. How they despised and scorned this world and its desires. In the glorious brightness of the pearl which is at the head of the Cross. With piercing eyes they looked and saw it. And desired to seize it."

This "Kumbhira" design at the head of the stone is thoroughly Buddhistic. It is a Hindoo idea which the Nestorian Missionaries adopted ; and that this "Kumbhira" design was quite common at the time may easily be seen from a monument at Seoul in Korea, which has been well illustrated in Vol. I. of Mrs. Bird-Bishop's "Korea."

The ceiling in the former Throne-room in Keum-chyong displays a similar device. Between Pingyang and Chinnampo the Japanese discovered some dolmens with interesting frescoes said to date back to the fourth or fifth century. A fine copy of such fresco may be seen at the Museum in Seoul with the same design.

* "In any world where there is not known

The Law of Buddha, which is the Pearl of good qualities,

There I pray that all (Bodhisattvas) shall be born

And show (the people) the Law of Buddha, just like Buddha Himself."

The quotation is from the Jodo-ron, or "Pure Land Sastra," i.e. the Amitayussutropadesa, translated by Bodhiruki in the 6th century A.D., and Don-ran compiled a commentary on this Sastra; and upon this work, according to Dr. Nanjio, the theology of Doshaku and Zendo was built (sce the Introduction, XXV., "A short History of the Twelve Japanese Buddhist Sects," by Bunyo Nanjio, M.A. Oxon.). 
In the centre of the figure-head right under the Pearl is the apex of a triangle, which forms a canopy over nine clearly carved large Chinese characters arranged vertically in three lines which form the "Titular Heading" of the stone. Their literal meaning is "The Monument Commemorating the Propagation of the Ta-ch'in Luminous Religion in the Middle Kingdom."

Observing narrowly this roof-shaped, triangular form, we cannot but be struck by the unique and most suggestive symbolic signs, viz. the Cross, the Cloud, the Lotus-flower and two branches of a tree or grass-which may be taken either for a myrtle-branch, or a lily-the one a regular Buddhistic emblem, and the other a familiar Christian symbol.

The Cross on the stone is said to be not very clear now, and must almost be searched for before it is found. But in the rubbing of the inscription it comes out quite clearly.

The form of the Cross is said, by one authority, to be a copy from memory of the Roman Papal Cross of the sixth century; but it somewhat resembles that on St. Thomas's tomb at Meliapor in S. India, and like it, bursts into fleurs de lys at each point, just as Père Somedo describes. Be that as it may, the Cross symbol is quite sufficient to prove that the stone itself is a Christian monument !

Beneath the Cross-i.e. supporting the Cross, there is the Cloud, which the Chinese describes as a "Flying-cloud" (飛雲) or “White-cloud” (白雲). This is the characteristic symbol of Taoists as well as of Mohammedans in China.

Beneath this Cloud there lies a Lotus-flower (蓮 室), the characteristic emblem of Buddhists. The design was doubtless used to denote that the "Three Religions are One."

Then comes the inscription (which consists of one thousand nine hundred Chinese characters and about fifty 
Syriac words), besides some seventy Syriac names in rows on the narrow sides of the stone with the corresponding Chinese characters which denote the Chinese synonyms or phonetics for the Syriac names.

These Syriac names alone supply a unique key whereby to discover the old sounds of the Chinese characters in the T'ang Era.

In the text there are three or four Syriac words, such as "Satan," " Messiah,"-"Eloah," as well as Sanscrit words, such as "Sphatica," "Dasa"; and even one Persian word to denote "Sunday," the first day of the week, "Yaksambun" (耀森文), besides a great many more Buddhist and Taoist expressions, and still more extensive quotations from the Chinese Classics.

This is a very important question, but so far it has not Where was been made clear. There are three or four different the Stone first dis. covered? theories as to the exact spot where the Nestorian stone was excavated in the early part of the 17th century.

The first theory, started by Martini and others, insists that the stone was first dug out at an old town called San-yüan (三原) which is located 90 li (i.e. 35 miles) to the North of Hsi-an-fu, and which is the native place of the well-known Chinese Christian and High Official, Dr. Philippe Wang (王洪激的.

But this opinion cannot be so readily accepted, since Pere Trigault and his party who were in San-yüan in 162E A.D. do not maintain this view.

Trigault was ordered in April of 1625 by Pire Emmanuel Diaz (jr.), who had been appointed Superior of the Society of Jesus in 1623 , to make every effort to have a house built outside the Metropolis Hsi-an-fú. But Trigault had scarcely arrived at San-yüan when he fell sick and was laid in bed for five months.

By the time-Trigault recovered from his illness, Dr. Philippe 
Wang had begun cautiously to suggest Trigault's plan to the Viceroy and some other mandarins in Hsi-an-fu : and finally he visited the metropolis together with Trigault some time in November, 1625.

If the stone had been in San-yuian (三原), these two men should have been the first eye-witnesses to bear testimony on this point. But neither of them gives any testimony in favour of the theory. On the contrary, Trigault says in his diary, as we are told: "This year, 1625, outside the country-town of Chou-chih, which was ten leagues away from the metropolis, a stone was discovered, on which the Chinese and Chaldean writings were inscribed. By these writings we can be sure that the Law of our Lord was preached to the Chinese a long time ago."

The second theory says that the stone was found in the suburb of Hsi-an-fu. This was asserted by Lin Lai-chai (林來架), a great Chinese authority on "Metal and Stone writings." He says :

“A devout child of Tsou Ching-ch'ang (制静長), Governor of Hsi-an-fu, died rather suddenly. The grave for the child was dug in the South of the Ch'ung-jên-ssŭ (崇仁寺) (a Buddhist temple in the Western suburb of Hsi-an-fu). The workmen lighted on a stone which had been buried several feet deep in the ground. This stone proved to be the Nestorian Monument !"

Now, the south side of the Ch'ung-jên-ssur is in the western suburb of Hsi-an-fu. The distance from the City gate is about one mile and a half.

If we were to accept this second theory, we might safely conclude that the stone had been originally erected in the precincts of the first Nestorian monastery which was built in 638 A.D., for the Ch'ung-jên-ssŭ itself is very close to the ancient site of I-ning Ward (義覃坊).

But this theory, too, cannot be accepted as so many authorities are against it. 
The third theory says that the stone was found at a certain place not far from Chou-chih (蓝厔縣). Now, Chou-chih is 160 li (i.e. about 65 miles) south-west of Hsi-anfu, whilst the place where the stone was discovered is said to be 30 miles from the capital.

Père Havret, author of " La Stèle Chrétienne de Si-nganfou," concludes as follows :

It is not at San-yuian nor in the suburbs of Hsi-an, but at or near Chou-chih-a place 30 miles from Hsi-an-fu, that the stone was actually found!

In support of this theory, Père Havret quotes some very rare works on the stone, and very precious documents preserved only at Rome. The great names of Kircher, Trigault, Bartoli, Thomas Ignace Dunyn-Szpot, and Antoine de Gouvea, who bear testimony in favour of this theory are enough to strengthen it.

But here comes in the fourth theory which insists on the stone being found in the neighbourhood of Hsi-an-fu and which we must harmonize with the third theory. The theory was that of Emanuel Diaz and Alvarez Semedo. The former wrote a book on the Nestorian Inscription in 164I A.D., whilst the Tatter went up to Chang-an to examine the stone by himself in 1628 A.D. It is moreover strongly supported by the writings of the two most famous Chinese Christians of the time, Dr. Leon Li (李之落) and Dr. Paul Hsü (徐光啓); and it was to the former that the first rubbing of the Nestorian Inscription was sent by Chang Kêng-yü (張展虜), who lived in Ch'i-yang (忮陽) 50 li east of Fênghsiang-fu (鳳翔 府), which is situated 165 li (i.e. 70 miles) north-west of Chou-chih in 1625, whilst Chang Kêng-yui himself does not say that he saw it at Chou-chih as alleged by some writers.

On the 12 th of June, 1625, Dr. Leon Li writes :

"During my residence in retirement between Ling and Chu (i.e. Hang-chou) Mr. Chang Kéng-yü, a native of Ch'i-yang, 
who is one of our best friends, sent me a rubbing of an inscription of the T'ang Era, saying : 'recently in Ch'ang-an, they dug out a stone bearing the title, 'The Monument Commemorating the Propagation of the Luminous Religion in the Middle Kingdom.' We have never heard of the name before. But is this not the same Western Holy Teaching that has been preached by Matteo Ricci ?" etc.

In 1627, Dr. Paul Hsü (徐㳣熙), a high official of the Chinese Government, wrote a book called "Iron Cross" (鉠十字) in which he vindicated the Christian Faith. He says :

"In Ch'ang-an, they dug out 'The Monument Commemorating the Propagation of the Luminous Religion in the Middle Kingdom." "

In his book called " A Critical Study on the Nestorian Inscription"(唐景教碑頌正淕), Emanuel Diaz says : "Originally the stone was discovered in the third year of the T'ien-ch'i Period (天 砶三年) (i.e. 1623 A.D.) at the base of a ruined wall in Kuan-chung (關 中) (i.e. Hsi-an district) while the workmen were digging the ground by an official command."

The "Kuan-chung" of Emanuel Diaz, as every one knows, is nothing but the classical name for Ch'ang-an and its neighbourhood. Of course it includes the western suburb of the modern Ch'ang-an and in wider sense it even includes Chouchih itself-which once formed the westernmost end of the Ch'ang-an district.

We think it entirely wrong to say that the stone was discovered in Hsi-an-fu, because it was actually unearthed in 1623 at a certain spot thirty miles west of Hsi-an-fu as insisted on by those who hold the fourth theory; whilst on the other hand we deem it equally wrong to insist that the stone was discovered at Chou-chih, because it was actually excavated at a spot thirty miles east of Chou-chih, as is equally alleged by those who maintain the third theory.

In fine we may conclude that the stone was discovered 
at a certain spot just between Hsi-an-fu and Chou-chiha few miles nearer to Hsi-an-fu than to Chou-chih. After all, Alvarez Semedo was not wrong in saying that the stone was discovered in the western neighbourhood of Hsi-an-fu. .

We are told by Alvarez Semedo, as well as by Père Havret, that the Governor of the Hsi-an Prefecture hastened to the spot where the stone had been discovered and paid homage to this ancient relic by making a most profound and solemn bow to it, and ordered the transportation of the stone to the outside yard of the Taoist temple in the western surburb of Hsi-an.

Long as the distance is and heavy as the stone was, the transportation of the Monument to the western suburb of Hsi-an by the Tsao-Ho (泉 河) and then by the Wei-Ho (渭河) may have not been so difficult a matter; the stone was carried there and stood there until 1907.

It was in 1625 A.D. that the existence of the stone When was attracted the attention of the Roman Catholic the Stone discovered? missionaries in the Far East, who then made it known to the Christian world in Europe.

Although there are three different theories about the date of its discovery, so far no one has ascertained what it was exactly ; but it is generally supposed to have been discovered in 1625 A.D.

First of all, Emanuel Diaz in his book published in 1644 A.D., fixed the date of its discovery as 1623 A.D.

But many authorities agree in saying that it was discovered in 1625 A.D., since Nicholas Trigault who visited Hsi-an-fu in I625 A.D. saw the stone in the back yard of Chin-shêng-ssŭ in October of that year, and says that it was discovered in 1625 A.D.

Dr. Léon $\mathrm{Li}$, as we have remarked already, wrote on the 12th of June, 1625, using the word "recently." So there may be some who would insist that the stone was discovered in 
the early months of 1625 A.D. But it must have taken at least a few months for the rubbing sent by Chang Kêng-yü to reach $\mathrm{Dr}$. Léon $\mathrm{Li}$; for the one was residing in about 130 miles west of Hsi-an-fu and the other was in the neighbourhood of Hang-chou-fu, at Che-kiang.

If Chang Kêng-yü himself had seen the stone at Chou-chih, as stated by Mr. Moule, there would be no difficulty in fixing the date as well as the place of its discovery. But so far we fail to find any positive testimony to prove what these writers say.

On the contrary, we think that Chang Kêng-yü could not have seen the stone in the eastern neighbourhood of Chouchih for several reasons. For instance, granting that the stone was actually found at Chou-chih, it must have been some time before the news of the discovery of the stone reached him in his home at the foot of $\mathrm{Ch}^{\prime} \mathrm{i}$-shan, which is 70 miles away from Chou-chih. How much more so if the stone was actually discovered 35 miles away from Chou-chih105 miles away from his home! We think, therefore, that the news of the discovery of the Nestorian Stone spread much morely quickly after, not before, its removal to Hsi-an-fu by the end of 1624 or in the early part of 1625 A.D.

So Chang Kêng-yü must have heard of the stone very early in 1625 , and if he saw the stone we think it was at the western suburb of Hsi-an-fu-but not at Chou-chih : and it must have been some time in March or April that he got his rubbings made to send one copy of them to Dr. Léon $\mathrm{Li}$ in Hang-chou.

Mr. Ch'ien (錢大肵), a Chinese authority on "The Inscriptions on Stone and Metal," tried to fix the date of its discovery between A.D. 1573 and 1620 .

Judging, therefore, from the evidence, it must have been, beyond doubt, already discovered and removed to Hsi-an-fu as early as 1625 A.D. So it is quite safe to say that it was 
discovered sometime early in 1625 A.D. if we cannot accept Emmanuel Diaz's theory of 1623 !*

Anyhow it must have been discovered before March in 1625 A.D., although not earlier than 1620 A.D., for in that year the famous Jules Aleni, one of the most energetic of the Jesuit missionaries, visited Shen-si. Had the stone been already exhumed, he would certainly have heard of it. We think that his complete ignorance of the stone must have been due to the fact that it had not then been discovered.

The exact circumstances under which the stone was How was it discovered are not known, and we are still in the discovered? dark as to who actually did discover it.

A great authority on Chinese archæology says that some workmen found it when digging a grave in the suburb of Ch'ang-an wherein to bury the child of a town official, and that the people of Ch'ang-an at that time believed the discovery to be due to the guidance of the departed spirit of this child, who was a most earnest little Buddhist! Another authority says that a farmer when ploughing, happened to light on the stone. Mr. Moule says :

"Early in the year 1625, perhaps about the beginning of March, trenches were being dug for the foundations of some building near the district town of Chou-chih, thirty or forty miles to the west or south-west of the city of Hsi-an, when the workmen came upon a great slab of stone buried several feet beneath the surface of the ground."

Differing as these three accounts do, all agree on one point, viz. that the Nestorian Monument was dug out of the ground. It had been buried. no doubt, for a long, long time.

* The best attested dates and facts make it at least possible that the stone was discovered in March, 1625. There are six statements that the stone was found in 1625. One of these is certainly, and another probably, by . Trigault himself, who spent the greater part of 1625 at or near Hsi-an. Trigault had been specially ordered to examine the stone, so his evidence is likely to be good. He died in 1628 or 1629 , so his evidence must be very nearly contemporary-one statement is : hoc anno r625 inventi. (The author is indebted to Mr. A. C. Moulc for these useful informations.) 
One advantage this monument enjoys over other old monuments in China is its perfect state of preservation-due to its having been so long buried. Had it stood above the ground all these II3O years, it would not have been in its present condition, and the writing upon it would not have been so legible!

Important as the question is, nothing definite in regard Where was to it has ever yet been made out. But the fact the Stone that the stone was discovered buried in the 781 A.D.? ground between Hsi-an and Chou-chih naturally suggests two theories.

One is that the stone might have been erected in Chouchih instead of Hsi-an. Mr. Moule says :

"The fact that the original church at the capital seems, as we shall see, to have survived that edict (of A.D. 845) is thus an argument in favour of the first erection and discovery of the monument at Chou-chih rather than, as some early authorities state, at Hsi-an itself" (p. 79, "Journal of the North-China Branch of the Royal Asiatic Society," Vol. XLI., Shanghai, 1910).

In order to decide whether or not this new theory is right, we have to describe to a certain extent the state of things at Chou-chih in 78I A.D. as well as we possibly can.

Chou-chih itself is sixty-five miles west of Hsi-an-fu and its old name was Chou-nan (周 南), but ever since 206 B.C. it has kept the name of Chou-chih (警厔). According to an authoritative Chinese dictionary, the Chîng-tzü-t'ung, "Chou" means " mountain-corner" and "chih" means "river-bend."

The name describes the town which occupies the headland of the delta formed by the Wei-ho and the Tsao-ho. It was noted for its beautiful scenery-both land and water.

The famous Liu Tsung-yüan (770-819 A.D.), was the Governor of Hsi-an from 803 to 806 A.D., and among his many writings we have found two masterpieces of Chinese classical literature. The one is called "The Inscription on 
the Wall of the Post-town Hall " (䁺使舘壁記) dated 804 A.D., and the other "On the Completion of the New Banqueting Hall at Chou-chih" (盆屋縣新食堂記) dated 802 A.D.

In the former he says: "Between Cliang-an and Chou-chilh there are eleven stages. Their military stronghold is Yangchou (洋州). Their military post is known by the name of Hua-yang (華 謁).” In the latter, he describes this banqueting hall, which is nothing else than a sort of English club in the heart of China in 802 A.D. The writings themselves throw an abundant sidelight upon the social life of China in the beginning of the ninth century. So we give here a full translation of the originals.

We are perfectly aware that the original is a perfect specimen of prose literature-a gem of Chinese literary composition, whilst the translation, however good and faithful it may be, is like a "broken piece of a tile" as the Chinese have it. Literary translation is something like looking at a beautiful embroidery from the wrong side!

"In the year 802 A.D., the banqueting hall was completed at Chou-chih. It stands on the right side of the town hall. Since the first outbreak of the rebellion (i.e. that of General An Lu-shan in 755-756 A.D., followed by that of General Shih Ssŭming in 759 A.D.), the western district (西 效) of the Imperial city became an important strategic point in the defence of the capital ; and Chou-chih was made outpost headquarters of the Imperial army for twenty-six years. The inhabitants could not remain there: they all fled for their safety from friend and foe. So when the army left the town at last there remained nothing but ruin and desolation! The town was really unfit for human habitation for another nineteen years.

"There was no town life in Chou-chih for a great many years, and in consequence the Chou-chih people had very little occasion to meet together for a long, long time !

"Very recently, however, the town officials were able to 
restore the order and grandeur of Chou-chih. Already they have restored the broken bridges and ruined country roads. They have built warehouses and granaries ; they have rebuilt the school-houses.

"Saving odds and ends out of these public building and construction expenses, one of the town officials succeeded in adding to the town buildings this large and beautiful banqueting hall. The dining-room itself measures twentytwo feet long from south to north with proportionate width. The surrounding verandas are imposing, whilst the beams and posts of the building are all in exquisite taste. The beauty of the garden and the dignity of a long flight of stone steps leading up to the entrance all clearly show the nature of the town, whilst the building itself is a credit to the people of Chou-chih.

"With the lofty mountains before and behind and the murmuring brook streaming at the foot, this new 'banqueting hall' claims to be just the place both for meditation and for merry-making.

"We are told that as soon as the building was completed, a good round sum of money was assigned as a banqueting hall fund to meet the running expenses of the building.

"Now every month the town officials meet here and enjoy themselves. And yet order is kept very decently in coming in and going out, and even the seats are arranged according to their official rank; thus, what with salutation and what with laughter, they can know one another well whilst lectures and discussions make them understand the essentials of the present-day politics.

"The cooking is good and the tables are all nice and clean, whilst the wine is excellent. In this hall they can enjoy all the real pleasure of fellowship. Even if they had come here as enemies, they would all go away as friends.

"We all know that the social dinner-party is a very old institution. Every official circle in the capital nowadays has 
organized a certain kind of society. [Kuan-nei (i.e. Kumdan)] is the Imperial District, and the officials should be well informed with all important knowledge, and be kept in touch with one another. Seclusion and society make a wide difference! We ought to be solemn and stern, and yet at the same time harmonious and kind! With friendly intercourse among the officials, all forms of suspicion will disappear and their good words alone become conspicuous! Let all who visit this hall remember the original idea of its nature, and let this true idea last for ever and ever!"

This shows that Chou-chih was made an outpost citadel in 758 A.D., and remained so for 26 years, that is to say, until 784 A.D., and that after the army left the town continued for nineteen years in ruins!

This fact was well expressed by the famous $\mathrm{Lu}$ Lun in his poem written in 785 or 786 A.D., entitled : "Coming back to Chou-chih in Early Spring, I address my friends Kêng Wei and Li Tuan”（早春解蟼厔寄耿 湋李端), which may be roughly translated as follows :

"The sun now shone on fields where wheat once grew.

The garden plots, the groves of green bamboo,

The village streets were thronged with roving deer;

Tall weeds and ruined wells where once was cheer.

One flowering tree alone that broke the gloom

Was solitary there beside a tomb.

Unbroken ice had settled on the spring

From which we tried the water sweet to bring.

A stony plain as far as eye could see

Replaced the fertile fields that used to be.

Alas! alas! how desolate the scene,-

The village waste before the mountain green!

The only cheering token that is mine,

Behold this branch plucked from the changeless pine ?"

Thus two contemporary writers agree in saying that 
Chou-chih was a deserted village in 781 A.D. when the stone was erected! But must we suppose that the stone had originally been erected at this deserted town of Chou-chih in 78 I A.D., because the stone was dug out at a certain spot near Chou-chih-35 miles east of Chou-chih and 30 miles west of Hsi-an? Certainly we think not.

Then must we suppose that the stone was originally erected somewhere in the western neighbourhood of Ch'ang-an?

But so far as the text of the Inscription is concerned, there is no knowing where the stone was originally erected. and any conjecture may be possible.

Our supposition is that the stone had originally been erected not far from the very spot where it was unearthed in 1623 A.D., and that place may have been one of "the seven post-towns" which existed between Ch'ang-an and Chou-chih as described by Liu Tsung-yüan in 804 A.D. What he calls "Yang-chou" or "Hua-yang" may have been in the locality where the stone was discovered. It is our opinion that this stone was erected at a certain post-town 30 miles from Hsi-an-fu, and that the place must have had something to

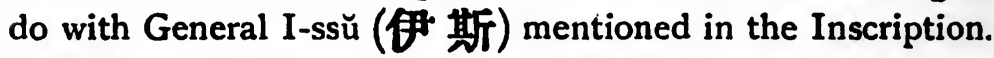

The great General Duke Kuo Tzŭ-i died six months after the erection of the stone, but evidently General I-ssŭ himself was living-this is certain from the Chinese text of the Inscription.

When the news of its discovery reached Hang-chou-fu How was the (杭州 府) sometime in 1625 A.D., there were a Stone made known to the world? guiet hiding after a recent persecution in Hangthe world? quiet hiding after a recent persecution in Hangchou-fu (杭州侍) as well as to escape from the dangerous mobs then so common, owing partly to the weakness of the Ming Dynasty and partly to the influence and instigation of the rising Manchus, who had begun to establish themselves at the expense of the Mings, and who actually came into power 
in 1644 A.D. As early as 1618 A.D. the founder of the Manchu Dynasty rose in rebellion against the Ming Dynasty, and began to carry out the plan which ended in the overthrow of the reigning Ming power. Thus disorder ruled everywhere, and the missionaries were not safe at all.

Among the missionaries then in Che-kiang (浙江省) was the famous Alvarez Semedo, Procurator of the Provinces of China and Japan. In his book, "History of the Great and Renowned Monarchy of China " (translated into English from the Portuguese original in 1720 A.D.), after expressing his great delight at the good news which was received by $\mathrm{Dr}$. Leon $\mathrm{Li}$ from his friend Chang Kêng-yü in the neighbourhood of Ch'ang-an, he goes on to say:

"The news was received with a spiritual jubilee in A.D. 1625. The Chinese workmen came upon a great slab of stone while they were digging trenches to lay the foundation stones at Chou-chih, not far from Hsi-an-fu, the capital of Shensi. The size of the stone proved to be 9 empan * in length and 4 empan wide and I empan thick.

"On the extremity of the stone there is the figure of a pyramid, which is I empan at the base and 2 empan high at the apex. In the centre of this pyramid there is a beautiful cross whose ends, finishing in fleurs de lys, resemble that carved upon the tomb of the Apostle St. Thomas in the city of Meliapor. The cross is surrounded by clouds.

"As soon as this curious stone was discovered, the Chinese reported it to the authorities, and the chief official came on horseback, and, after inspecting it most carefully, ordered it to be set up. He also ordered a temporary cover to be made for it so as to protect it from wind and rain. When the newlydiscovered stone was set up, the public were allowed to see it."

The removal of the stone from Chou-chih to Hsi-an-fu must have occurred sometime in 1623 or 1624 A.D. Semedo

* This may be the corruption of the Chinese word for measurement. It seems to correspond to one foot. 
himself went up to Hsi-an-fu in 1628 A.D., and describes his happiness in having been entrusted with the affairs of the Christian Church newly built there, because living in the small house attached to it afforded him the precious privilege of leisure wherein to study and consider most carefully the Nestorian Inscription.

When he read the Chinese text he felt as St. Paul once had done: "God indeed had not left Himself without a witness!" He thought that the long-felt desire of his predecessors, Matteo Ricci, Jules Aleni, and others was at last fulfilled, and the more he studied it the more delighted he was with the stone.

Although he could understand the Chinese text fairly well, Semedo could not decipher the curious foreign writing on the stone-which he at once perceived was neither Hebrew nor Greek, but he did not recognize that it was Syriac-the ecclesiastical language of the Nestorian Church as well as the commercial tongue once spoken throughout Central Asia. So he went to Cochin-China on purpose to consult Père Antony Fernandez at Cranganor, knowing how well versed he was in reading the books of the Christians of St. Thomas. Fernandez assured him that the characters were Syriac, like those which he himself was then using-i.e. what is now known as Estrangelo.

The text of the Inscription was first translated by a member of the Society of Jesus-probably Nicholas Trigault -into Latin, the universal language of Christendom in Europe. It appeared in 1625 A.D.

In 1628 A.D., an anonymous and incomplete French translation from the Latin appeared-French being to the Catholic world what English was to the Protestant world.

In I63 I A.D. a complete Italian translation was first made from Portuguese-probably by Semedo, whose Portuguese translation with notes appeared afterwards in 1638 A.D.

The news of the discovery naturally flew to Rome as well 
as to Lisbon, and by 1631 A.D., only eight years after the stone had been lifted out of its grave in the place not far from Hsi-an, the whole story had been made pretty well known amongst the leading scholars of Europe as well as in the missionary field.

In 1636 A.D., the famous Athanasius Kircher, a man of varied research and a professor of mathematics in the College at Rome, described the discovery of the stone in his book, "Prodromus Coptus Sive Aegyptiacus," and many years later-in 1667 A.D. - he again treated the subject in a book called "China Illustrated," published at Amsterdam.

By giving a transcript of the Chinese and reproducing the Syriac text, he explained it thoroughly, and through his efforts the whole of the Nestorian Inscription in China was thus first submitted to the critics in Europe.

About the year 1653 A.D., Antoine de Gouvea translated it into Latin. M. Boym's Latin version of about A.D. 1653 was printed in Kircher's "China Illustrated," 1667 ; and in 1663 A.D. Daniel Bartoli published a compilation of all the previous works on the Inscription. And so the news spread gradually and steadily throughout the Catholic world:

Now let us see how it affected the Protestants. The news of the discovery was diffused chiefiy through the medium of the English language into which Semedo's work was first translated in 1655 A.D. - i.e. about two years after Oliver Cromwell was made Lord Protector of the Puritan Commonwealth of England, and only one year before the "Christianity-prohibition-board " appeared everywhere in the "Land of the Rising Sun" under the fourth Shogun, Iyetsuna.

Through the mighty pen of Edward Gibbon, the historian, the fact was again revealed to the world at the end of the 18 th century. During the 19th century many translations of the text appeared by such scholars as Dr. Bridgman (1845), Mr. Alexander Wylie (1854), and Dr, Legge (1888), in English; whilst amongst the French we have those of 
Abbé Huc (1857), M. G. Pauthier (1858), and Père Havret (1902) ; and amongst the German, those of Prof. Neumann of Munich (1866) and Dr. Heller (1885, 1897). All these and many more made the stone famous throughout the Western World.

Whilst European scholars have taken so much interest The study of in the Nestorian Stone of China during so many the Inscrip. years, we are ashamed to confess that very little
tion in the Far East. indeed has been done by either Japanese or Chinese!

For instance, in China itself where the stone is still to be seen, the study of the Inscription has neither been very popular nor attractive owing to the prevalence of anti-Christian feeling.

Only a few Chinese archæologists and students of the calligraphy of the T'ang era and those interested in "Writing on Metal and Stones," know of the stone's existence.

Generally speaking, the opinions expressed by Chinese scholars remind one of a blind man's description of an elephant, for sometimes their criticism is altogether beyond the mark, owing to their ignorance of Christianity itself, as well as of Syriac and of the foreign terms which are found in the Inscription.

A book, however, written by Mr. Yang Yung-chih (楊榮 鋭), called “A Critical Study on the Nestorian Inscription," gives a tolerably good account of the views of the Chinese Christians concerning the Inscription. But even this book, suggestive as it is in a way, is far from being complete, and does not quite come up to the standard of a critical study on the subject.

But we hope and trust that as a nation the Chinese will pay more attention to it, after Dr. Frits Holm's attempt to buy the stone for the British Museum in 1907, and since the first President of the Chinese Republic, Dr. Sun-yat-sen, in his official letter to the people of China on the 5 th of 
January, 1912, referred to the Nestorian Inscription in order to prove that China was once not behind the rest of the world in opening up her territories to foreign intercourse.

As the result of over fifteen hundred years' intercourse with China, and so many years' study of her literature and the adoption of things Chinese, Japanese scholars are generally accredited with as thorough a knowledge as the Chinese scholars themselves on all and every point of the classics and literature of China.

But, strange to say, very many Japanese do not know of the stone's existence, whilst very few take interest in it !

This is strange enough, but can be easily accounted for.

It was only in the year 1817 that the Nestorian Inscription was first made known to some learned Japanese through the importation of Chinese books, among which there was a large work called "A Great Collection of Inscriptions on Metal and Stone," compiled by the famous Wang Ch'ang (王萌) in 1805 A.D.

It deals with nearly one thousand inscriptions, long and short, from about 2000 B.C. down to 1264 A.D. The larger part of the sixty-fifth volume is occupied with the Nestorian Inscription. The whole text (except the Syriac) is given.

Although the work is not without errors of transcription, on the whole it is complete and contains even the compiler's own criticisms as well as those of others which were added to each text.

As soon as this work-one hundred and sixty volumes in all-by Wang Chang was inspected by the Government authorities at Yedo, the sagacious Kondo Seisai, InspectorGeneral of Publications and Imported Books, found the Nestorian Inscription in it, and concluding that it was related to the "Religion of Jesus," which was then forbidden by the strict law of the Shogunate, he declared the whole work of Wang Ch'ang to be proscribed in Japan.

Although Kondo Seisai was clever enough to discover 
the Inscription, the whole Japanese nation was kept so completely in the dark about the Nestorian Monument that they did not even hear its name until some years after the Restoration, A.D. 1865 !

It was only after 1872, when the Japanese Government in its Treaty with the Foreign Powers gave the people religious liberty by taking down the notorious "Christianityprohibition-boards," that we began to hear about the Nestorian Inscription in Japan.

During the most glorious reign of the late great Meiji Emperor (1867-r912), we can cite only three scholars who have paid much attention to the subject in their writings, viz. Dr. Takakusu, Dr. Kuwabara and the late Dr. Nakamura.

Since Mr. Holm carried the first replica of the Nestorian Monument to America - and since an Irish lady (the Hon. Mrs. Gordon) had a second replica made and erected on the summit of Koya San-the Holy Mount of Japan, it is surely the duty of the Japanese to make a pilgrimage there and study for themselves this wonderful stone with a view to solve, if possible, the religious difficulties and futile contentions in Japan and China which (being the largest missionary field of the world) are the centre of severe strife between natives and foreigners on the one hand, and of unhappy divisions between Christian and non-Christian relatives on the other.

That the civilization and culture of the T'ang Dynasty in China was really the model for the Japanese Government and nation, we already knew ; but when studying this Syrian Monument and its Inscription we feel that the Great $T$ 'ang did not fail to supply us also with a model for the religious policy of Japan!

When our Gyogi Bosatsu (680-749 A.D.), and Kobo Daishi (774-835 A.D.), and other advanced thought-leaders endeavoured to harmonize the Japanese national cult, they wisely took a leaf out of the Nestorian book in China! How the Japanese people can now best utilize the stone is 
therefore a question of paramount importance to the whole civilized world !

Believing as we do that this twentieth century will see China opened up in many ways, and that Chinese thought will become better understood in. Christendom as was that of India in the nineteenth century, we are strongly convinced that the Nestorian Monument will supply any European or American who desires to understand either China or Japan with the true compass for guiding him through his intricate course.

Soon after its discovery, the Nestorian Stone attracted the The reception attention of several Chinese scholars, who exof the News plained its important points as best as they in the West. could, according to their own ideas, and expressed their opinions without reserve.

But though all sorts of opinions were expressed, not one even suggested that the stone was "the fabrication of a later age." On the contrary, its calligraphic characteristics-on which the Chinese are great experts--(i.e. style and character of the handwriting) all Chinese scholars agree in pronouncing to belong decidedly to the T'ang era.

But in the West many noted men have expressed their opinions against the genuineness of the stone and its inscription. This seems very queer to the Japanese !

Prior to the nineteenth century, La Craze and Voltaire in France, Bishop Horne in England, and others contended that it could not be genuine, and they challenged it as "a Jesuit forgery."

Later on in the nineteenth century, Prof. Neumann of Munich, Stanislas Julien of Paris, the great Sinologist, who translated Hsuian-tsang's Travels, and others, threw doubts more or less on the genuineness of the stone; and in 1853 Prof. E. E. Salisbury published an article examining the opinion he had expressed in October, 1852, at a meeting of American Orientalists, "that the so-called Nestorian 
Monument was now generally regarded, by the learned, as a forgery."

Prof. Salisbury insisted that "seeing is believing," and that since he had met no one who had seen it in China, nor had any of his friends ever met such an one, he was not sure whether such a thing did actually exist in the interior of China or not! ("On the Genuineness of the so-called Nestorian Monument of Singan-fu," pp. 399-419, "The Journal of the American Oriental Society," Vol. III.)

On the other hand, great Sinologists like Alexander Wylie and James Legge of England, and M. G. Pauthier of France, confirmed its genuineness from various sources. Mr. Wylie published a translation of the Inscription at Shanghai in 1854. His translation is pronounced to be one of the best yet made. He then published in detail a series of discussions based on the consensus of Chinese authorities and on a great variety of historical and topographical notices, besides that of calligraphical notices of the T'ang era in "The Journal of the American Oriental Society," Vol. IV.

Indeed, we are glad to say that Mr. Wylie made it impossible for us ever to doubt its genuineness again!

Three years later (1857), M. G. Pauthier, in his famous book "Chine," fully acknowledged the value of Mr. Wylie's labours and made the very best use of all his materials, but he himself went far beyond Mr. Wylie's work, as he elucidated every point connected with the Inscription with a large amount of evidence, both internal and external, omitting, however, two very important points regarding the priest Ching-ching (景淨), who composed the Inscription and

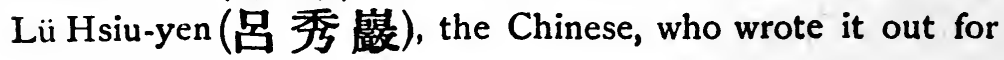
Ching-ching.

In I888, Dr. Legge published his translation of the Inscription together with the lecture which he delivered upon it at Oxford. As regards the Chinese text and 
translation, Dr. Legge's work stands very high. Short and insufficient as the lecture is, it is very suggestive and truly helpful.

The Monument was originally erected or, to speak more When was correctly, unveiled on the 4 th of February, 781 A.D. the Stone originally set up? The Chinese Inscription states that it was :

"Erected in the second year of the Chienchung period (i.e. 78I A.D.) of the Great T'ang (Dynasty), the year-star being in Tso-o, on the seventh day of the first month, the day being the Great Yao-sên-wên."

And these dates are also given in Syriac:

"In the days of the Father of Fathers, my Lord HananIshu, Catholicus, Patriarch."

And again :

"In the year one thousand and ninety-two of the Greeks $(1092-311=781)$ was erected this Stone-Tablet."

So it is quite clear that the Monument was set up on the $4^{\text {th }}$ of February, 781 A.D., when Hanan-Ishu was Patriarch of the Nestorian (or more correctly the Assyrian) Church. But this date does not agree with that of the Patriarchate of Hanan-Ishu, who (according to European writers) is generally said to have died in 778 A.D.

How can we account for this apparent discrepancy? Dr. Legge says in his book, "The Nestorian Monument in China," p. 29 note:

"This is an important note of time, and occasions some little difficulty. We know from the Bibliotheca Orientalis Clementino-Vaticana of J. S. Assemani, that this HananYeshu (same as Hanan-Ishu) was created Patriarch of the Nestorians at Bagdad in A.D. 774, and died in A.D. 778; whereas here is this Monument erected in A.D. 781. But is not this discrepancy rather a proof of its genuineness? The news of the Patriarch's death had not reached them at Ch'angan. In fact, according to Assemani (Vol. III., I, 347) the canon for communication between more distant metropolitan sees 
and the Patriarchate required the interchange of messages only once in six years."

But Dr. Wright (the author of "A Short History of Syriac Literature ") says that Hanan-Ishu, the Patriarch, died sometime in 779 A.D. instead of 778 A.D., the date given by Dr. Legge; whilst Dr. Budge, the translator of the "Book of Governors," says in a foot-note that this pious Patriarch Hanan-Ishu succeeded Mar Jacob as Nestorian Patriarch in 774 A.D., and died in 780 A.D.

We think that the death of Hanan-Ishu probably occurred sometime in October or November of the year 780 A.D. Our ground for this is that as no two authorities agree about the date of Hanan-Ishu's death, we are compelled to adopt the date nearest to the date of the Inscription. On the other hand, we are told by Dr. Wright and others that eight months elapsed between the death of Hanan-Ishu and the tinal election of his successor, Mar Timothy. This brings the consecration of Mar Timothy down to May, 78I A.D., and the Nestorian missionaries in China could not possibly know of Hanan-Ishu's death at the end of 780 A.D., when the stone was finished and only waiting for the day when it should be unveiled. (The unveiling took place on the $4^{\text {th }}$ of February, 781 A.D.).

In the famous "Book of Governors" by Thomas of Margha, 840 A.D., this Hanan-Ishu is thus mentioned :

"And when the pious Hanan-Ishu, this other Catholicus, died, and a synod was assembled to appoint a Catholicus, the Election to the Patriarchate was ordered and prepared for the blessed Mar Isho-yahbh by all Bishops and Metropolitans and heads of believers, so that he might become the Patriarch," etc.

But Mar Isho-yahbh was not made Patriarch after all. Mar Timothy succeeded Hanan-Ishu in May, 781 A.D. (Dr. Wright says, 779 A.D., and Dr. Budge says 780 A.D., as we have already mentioned). The "Book of Governors," 
describing "how Timothy obtained possession of the Patriarchate by fraud, like Jacob who obtained by fraud the blessings of Isaac his father," says:

"And when Timothy saw the face of every man fixed upon our Mar Isho-yahbh, he advised him secretly when they were alone together and said to him, Thou art an old man, and thou art not able to stand up and meet the attacks of the envious, Ephraim of Elam, Joseph the son of Mari, and other opponents; but do thou excuse thyself, and become one of my supporters, and I will make thee Metropolitan of Adiabene; and to speak briefly, Timothy was appointed Catholicus and Patriarch, and was proclaimed among the heads of the fathers " (p. 383, Vol. II.).

Neither the news of Hanan-Ishu's death nor the result of the election had reached Nestorians in China before they finished the stone at Ch'ang-an at the end of 780 A.D.

We think that when they heard the news the Monument must have been already finished and set up, ready to be unveiled. And this is why the Inscription has Hanan-Ishu's name as Patriarch and Catholicus instead of that of Mar Timothy.

So this stone tablet is as old as Charlemagne, and the Inscription itself is older by seventy years than the famous Syriac "Book of Governors." It is twelve years older than the founding of Kyoto, the greatest of Japan's old cities.

The stone had been standing there in Hsi-an-fu for twentythree years, when our Kobo Daishi and Dengyo Daishi, the two greatest monks of Japan, visited China at the beginning of the ninth century, when Lü Hsiu-yen (呂秀筩), the penman of the Inscription, was the local official in T'ai Chou (台州), where was situated T'ien-t'ai-shan (天台山).

It is younger only by sixty-nine years than the oldest historical book, the Kojiki (古事記), that our Japan has produced. So if we regard this Inscription merely as a historical document it will be worth our while to study it. 
How much more so then, if it be the key wherewith to unlock some facts which were hitherto hidden from our knowledge!

"Rome was not built in a day!" and this unique Nestorian Monument was not set up until one hundred and forty-six years after the introduction of Assyrian Christianity itself into China in 635 A.D.

Thus the Monument was unveiled on the $4^{\text {th }}$ of February, 78I A.D., but nothing was known of the existence of such a stone either in China or in the West until I625 A.D.; and this very fact aroused suspicion amongst inquiring minds in Europe and America. This was not surprising at all, as they could neither see the rubbing nor yet read the original Chinese text!

We therefore feel our first duty is to clear away all such suspicions from our readers' minds, by placing before them every possible detail. What the historian, Edward Gibbon, wrote a century ago in his celebrated "History of the Decline and Fall of the Roman Empire," still holds good in the light of the latest discoveries. He said:

"Unlike the senators of Rome, who assumed with a smile the characters of priests and augurs, the mandarins, who affect in public the reason of philosophers, are devoted in private to every mode of popular superstition. They cherished and they confounded the gods of Palestine and of India; but the propagation of Christianity awakened the jealousy of the state, and after a short vicissitude of favour and persecution, the foreign sect expired in ignorance and oblivion.

"The Christianity of China, between the seventh and thirteenth century, is invincibly proved by the consent of Chinese, Arabian, Syriac, and Latin evidence. The inscription of Siganfu [Hsi-an-fu], which describes the fortunes of the Nestorian Church from its first mission A.D. 636, to the current year $78 \mathrm{I}$, is accused of forgery by La Craze, Voltaire, \&c., who become the dupes of their own cunning, 


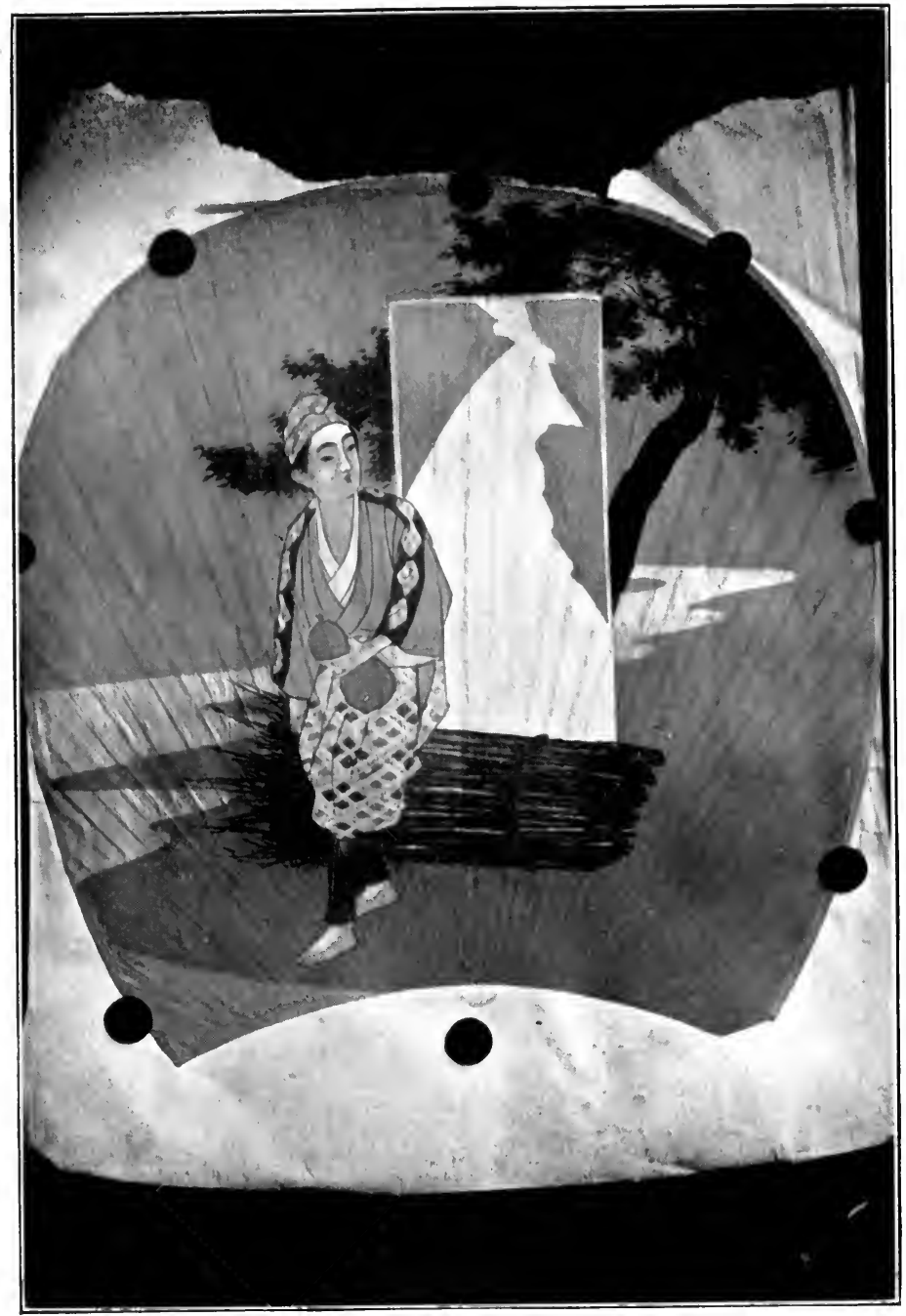

JAPANESE FAN, SIIOWING A PHRYGIAN CAP.

[To face $p \cdot 39$. 
while they are afraid of a Jesuitical fraud" (Chapter XLVII.).

The first external evidence is the fact that the overland External communication between the capital of China and Evidences. the Græco-Roman civilized countries around the Mediterranean Sea had existed long before the introduction of Assyrian Christianity into China proper in 635 A.D. The visit of the Nestorian missionary is only one of the many results of the political, social, and economical relations which had for centuries existed between China and Persia.

How great the economical activity was along the caravanroads-those wonderful land-bridges between the East and West-from China to Byzantium on the one hand and from China to Alexandria through Palestine on the other, as well as by the sea-routes to Persia and India, is not very difficult to ascertain from the historical and philosophical evidences left to us.

According to the "Spring and Autumn" (an historical book said to have been compiled by Confucius himself in 48I B.C.), the arrival of “the white foreigners" (白 狄) is mentioned several times. Whether these white people came from Persia, or from Parthia, from Bactria, or from the plains of Mesopotamia, or from "the lands beyond the Great Rivers"-Tigris and Euphrates-we cannot tell.

But what Ssŭ-ma Chcien (司 馬遷) wrote in his “Chronicles" (史記) in 95 B.c. ought to be considered carefully as Sinologists have proved its authenticity. According to this book, already as early as 214 B.C. the Great Wall was built to defend China against the Huns.

In the year 122 B.C., the Chinese general Chang Ch'ien (張 篤) was sent at the head of an embassy to the "Western Regions." Among the names of Western Regions then known to China were Ta-ch'in, Tiao-chih, Bactria, Parthia, and Persia, besides the name of India, which they sometimes used to express Persia and Parthia. 
The Nestorian Inscription says: " $\boldsymbol{A}$ virgin gave birth to the Messiah in Ta-ch'in," and we are sure that by "Tach'in" is meant Judea.

But in Chinese books of historical and literary worth, Ta-ch'in is mentioned under three different names.

In the books written before the fifth century A.D. the country was called Li-k'an (黎许), whilst in those written after the ninth century it was called Fu-lin (茀菻).

In order to determine which country was meant by these names Sinologists have written many books and pamphlets.

According to the best authorities, Li-k'an, Ta-ch'in and Fu-lin seem to have denoted the Roman Empire in the East. (Dr. Hirth: "China and the Roman Orient.")

We cannot deny the fact that during the middle part of the Han Dynasty (206 B.C. -8 A.D.) the Chinese Empire flung its sphere of influence very far and wide towards the "Western Regions," beyond the Gobi Desert and to the old Babylonian plains.

The above-mentioned Chinese embassy (that of Chang Ch'ien) crossed the Oxus and even visited a city called "ANTU," which has been identified with Antioch by Dr. Hirth, while Dr. Shiratori, professor of the Imperial University of Tokyo, claims that it was Alexandria.

This embassy was astonished to find the people in Tach'in using silver coins at a time when copper coins were in common use in China. They felt it very strange to see the Royal image struck on the coins; and they wrote back to China: "These people make coins with silver, and each coin bears the Royal image on it. In case the King should die, the new coins are made after the image of the new King."

Already paper was in common use in China as a writing material. But in Ta-ch'in they did not yet know the use of paper, vellum (skin) being used for writing purposes. So the embassy reported to China: "These people write on parchment." 
And they also thought the mode of writing very strange, and reported: "These people when they write proceed from left to right and some from right to left," instead of from the top as the Chinese do.

All these things were witnessed by Chang $\mathrm{Ch}$ 'ien and his party as early as 122 B.C.

Again, in 94 A.D. the Chronicle says: "General Pan Ch'ao (班超) and General Kan Ying (甘英) and their party visited Ta-ch'in by the special orders of the Emperor $\mathrm{Wu}$ of the later Han Dynasty (後漢武帝).”

It is recorded in the official Chronicle that "in the ninth year of the Yen-hsi period [166 A.D.] of the Emperor Huan, the King of Ta.ch'in by the name of An-Tun (安敦) sent an embassy to the court."

This "An-Tun" has been rightly identified with Marcus Aurelius Antoninus, who ruled the Roman Empire from 161 A.D. to 180 A.D. It is well known that he made war against Parthia, the Roman troops being under the command of Lucius Verus (162-165 A.D.). This commander, however, soon gave himself up to dissipation in Antioch, whilst his legates carried on the war with great success, and finally conquered Antaxata, and burned Seleucia and Ctesiphon. Thus part of Mesopotamia once more came under Roman sway as it had been in Hadrian's reign (117-1 38 A.D.).

The epithets "Parthicus, Armeniacus, and Medicus" were given to Marcus Antoninus, and these commemorated his brilliant victories over the Parthians. Hence in 166 A.D. there was nothing to hinder the Roman Emperor from communicating with China. The Roman sphere of influence in the Orient was extended to the territory outside the Great Wall of China; and to her capital Hsi-an-fu an embassy was sent, as is written in the Chinese Chronicles.

And knowing that this important event took place only one year before the death of Justin Martyr at Rome and of Polycarp at Smyrna, we cannot deny that in the lifetime of 
these Christian martyrs Rome had already come into contact with China. And owing solely to the immense distance China was fortunate enough not to clash with the Roman arms.

Again we read in the Chronicle that an embassy from Ta-ch'in visited the Chinese Court twice during the third century, i.e. between 265 A.D. and 287 A.D.

This fact agrees with what we read in European history. Aurelianus (270-275 A.D.) defeated Zenobia in two battles, one at Antioch and another at Edessa. He subdued Syria, besieged and destroyed Palmyra and reconquered Egypt. Again we read that in 282-283 A.D. the Emperor Carus captured Ctesiphon in the course of an expedition to Persia.

From what is written in the Chinese Chronicles it is most natural to conclude that these two Roman Emperors followed the examples set by Marcus Aurelius Antoninus about 100 years earlier.

It is also written in the Chinese Chronicles that in the year 381 A.D. more than 62 countries in "the Western Regions" either sent embassies or brought tribute to the Chinese Court.

We do not know which these " 62 countries" were or how remotely scattered, but the fact proves that China was then opened widely to foreign intercourse; and that her secluded and exclusive existence is of later development.

In the early centuries not only the Chinese Government, but the Chinese people at large were open-hearted and very active. For example, 399 A.D. the famous monk, Fa-hsien (法顯), set out on his travels throughout Buddhist lands. He spent six years in reaching Central India, where he spent over six years. On his return, he spent three years on the journey to Ch'ing-chou (416 A.D.).

These historical facts suffice to prove the existence of the Land-bridge between China and the Roman Orient; and that ancient China had overland communication with 
Mediterranean countries as well as with India. The route may have been by way of Khotan and Turkestan, to Northern India, Afganistan, etc. It would be very strange if the energetic Syrian Christians, full of true missionary zeal, did not proceed to China after reaching Persia about the middle or end of the second century!

"When one recollects that Antioch was the motherChurch of Gentile Christianity, the spread of Christianity can be illustrated from the standpoint of Syrian trade activity.

"One of the most remarkable facts in the spread of Christianity is the rapid and firm footing which it secured in Edessa ... for there is no doubt that even before A.D. 190, Christianity had spread vigorously within Edessa and its surroundings, and that shortly after 201 , or even earlier, the Royal House joined the Church, so that Christianity became the State religion; while even during the Easter controversy (c. 190 A.D.) 'the churches in Osrhoene and the local towns' (implying that there were several bishoprics-according to the Liber Synodalis, there were eighteen) addressed a communication to Rome. . . .

"The strong local Judaism in Edessa undoubtedly formed a basis for the spread of Christianity both here and still farther eastward to the bounds of Persia.

"It was Edessa and not Antioch-which became the headquarters and missionary centre of national Syrian Christianity during the third century.

"Sozomen (H. E., p. II8) says, "I think the introduction of Christianity among the Persians was due to their intercourse with the people of Osrhoene and Armenia, in all probability ; associating with these godly men they were incited to imitate their virtues also.' . . ."

It is natural to suppose (says Dr. Harnack) that after the conquest of Syria and sack of Antioch A.D. 260, many Christians of the district (together with Bishop Demetrianus of Antioch) were deported to Mesopotamia and Persia. 
Bardesanes of Edessa (born 154 A.D., died 222 A.D.). wrote: "Nor are the Parthian Christians polygamists, nor do Christians in India expose their dead to dogs, nor do Persian Christians marry their daughters, nor are those in Bactria and among the Getai debauched."

Hence, Christianity must have been already an important factor in the life of Persia and the other nations which are named.

"... Heresies," says Harnack, "swarmed in Eastern Syria and Persia even in the third century."

The above quotations are from Vol. II., pp. 140-148, of What we read Harnack's "Mission and Expansion of Christianity in Chinese iistory is supported by the
phllosophical between China and the countries around the evidences. Mediterranean, many foreign matters and manrers, words and thoughts, were introduced into China.

The foreign elements in the Chinese language, for example, are a most stimulating subject for investigation. As yet, only a very little has been done, but that little reveals much.

According to Dr. Otsuki, a great authority on the Japanese language, there are over one hundred and twenty Sanscrit words in the daily parlance of the Japanese people. The very first word a foreign visitor hears in Japan is "Danna," the Sanscrit for the English "Master" or "Lord."

In A.D. 170-180 the Nirvana Sutra was translated into Chinese by a Yüeh-chih monk named Chih-i, and an epoch of vigorous translation work set in ; so extensively, indeed, that the people of Shensi, Pechili, and Shansi at the beginning of the fourth century learned Sanscrit-such was their eagerness to study the Mahayana Buddhist literature in the originaland as a result, the dialect of North China became particularly Sanscritized.

According to Prof. Giles of Cambridge and other great 
$\because$

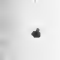




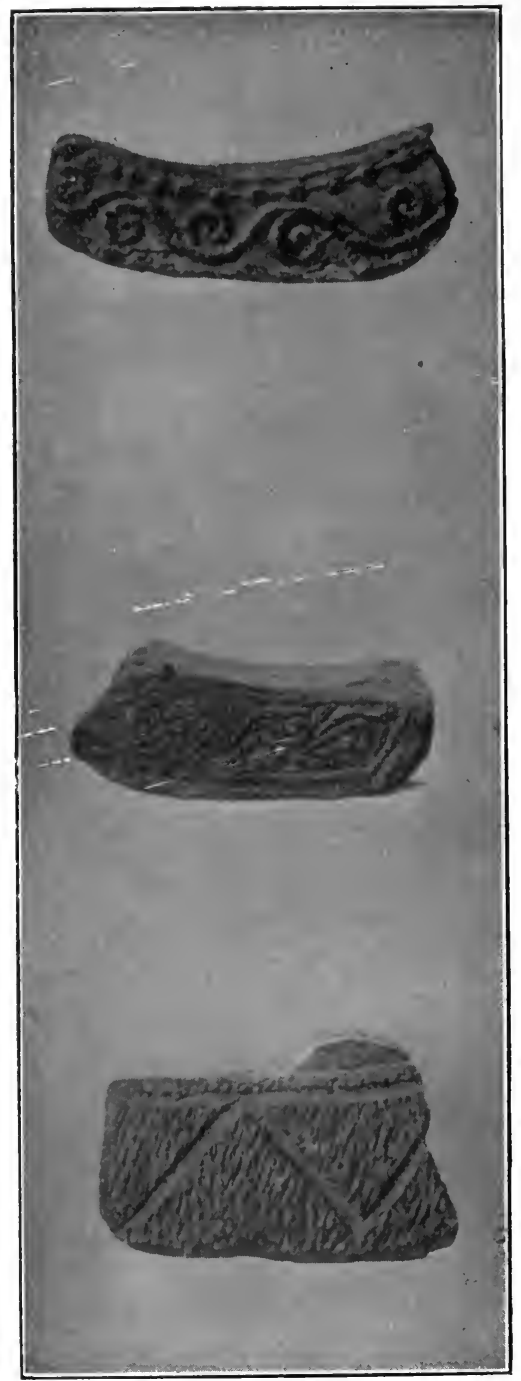

PIECES OF INCENSE-WOOD.

[To face p. 45 . 
authorities, some words which we Japanese had fully believed to be Chinese, because we borrowed them from China about twelve hundred years ago, are really Greek, Persian and even Hebrew words (p. r 34, "China and the Chinese," by Prof. Giles).

For example, “Bu-do” (㑘昀), a well-known Japanese word for the English "grapes," is pronounced "P' $u-t$ 'ao" in modern Chinese. But this is nothing else than a corruption of the Greek Borrovs. We read in the Chinese Chronicles (史記), written by Ssŭ-ma Ch'ien (司馬竞卷) in the 9Ist year B.C., how grapes were introduced into China from Ferghana together with fine horses from Arabia.

Again, the Japanese word "Sai-kwa" (欧 低) for the English "water-melon" is denoted by two Chinese characters representing "west-melon" instead of "water-melon." The Chinese pronunciation "Hsi-kua" corresponds exactly with the sound of the Greek ouxúa.

The Chinese word “Lo-po" (䔦萑) for "radish" is a corruption of the Greek word $\rho$ á $\phi \eta$. This word came over to Japan in three different Chinese forms (viz. 来䓳, 后源, and 橉谓) with one and the same Japanese reading for them all-"Daikon," "big root"-but not with the Chinese sounds-that is to say, the Chinese characters for $\dot{\rho} a \dot{\phi} \eta$ were introduced into Japan, but not the Chinese pronunciation of them.

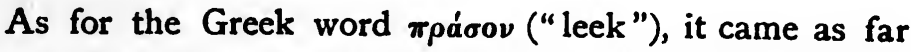
as the Korean peninsula, but did not cross the Tsushima Channel into Japan.

A kind of incense in common use among all classes in Japan is known as “Ansoku-ko" (安息香), “Ko” is the Japanese for the English word "incense," whilst "Ansoku” is the word used in China to represent Parthia. Our "Ansoku-ko" is therefore the "Parthian incense."

Now Parthia was known to the Chinese ever since the third century A.D. as “An-hsi" (安 息), or “the Kingdom 
of An-hsi," which was simply a corruption of "ARSAKES," the name of the founder of the Arsacide Dynasty, whilst the Parthian prince An-shih-kao (安世高), Arsakes, is very familiar to the Japanese as the translator of Buddhist scriptures into Chinese.

A tree from which in Japan we get wax is called "Hasi" or "Hase" (㠊). The word "Hase" or "Hasi" is the corruption of Po-ssŭ (波斯), Persi or Persia, in Chinese. This indicates that the tree was originally introduced from Persia through China and Korea; whilst the best kind of falcon in Japan was known as "Hasi-taka," which means "Persian hawk."

The name for pomegranate in China is "the Parthian fruit” (安息榴), showing that it was first introduced into China from Parthia, whilst the Chinese word "Shih" (佃), "lion," is said to be derived from the Persian "shir." The Persian word "Yesumband" (耀森文), for the first day of the week, was already adopted in the Chinese translation of the Indian books on astronomy in the eighth century.

Even the words “Satan" (婆彈) and “Messiah" (橛户訶) appear in two or three different forms in Chinese writings of the T'ang era. But how the Hebrew word "Shedek" appeared in Chinese works on astronomy as "She-ti-ko" (攝提格) is a mystery which we cannot explain. The Japanese word "Maru” (丸) or “Maro" (庥呂) once used as the honorific masculine in the sense of "Master," "Lord," or "Saint," but now chiefly used as the name of a ship, e.g. "the Tenyo Maru," can be traced back to the Syriac word "Mar," "Maro," or "Mari," meaning "Master," "Lord," or "Saint," and for which the Chinese character “Mo" (摩), or “Ma-lo" (麻囉), was used in China instead of "Maro" (麻呂), which we use in Japan.

If it be true that "where there is smoke there must be fire," we may safely conclude that these words suffice to 
prove that there was age-long communication between China and the Græco-Roman countries in the Mediterranean, and that what we have called land-bridges prepared the way for the coming of the Nestorian missionaries to Hsi-an-fu in the seventh century, so that nothing is more natural than the existence of Assyrian Christianity in China between the seventh and the thirteenth centuries of our era-if not far earlier !

Another external evidence is found in the Imperial Edict

Further external evidences. of 845 A.D., which ordered the destruction of the Buddhist temples and monasteries saying :

"As to the monks and nuns who are aliens and who teach the religions of foreign countries, we command that these-over three thousand-from Ta-ch'in (Nestorians) and Muhufu (Mohammedans) return to secular life and cease to confuse our national customs and manners," etc.

Again in the complete works of $\mathrm{Li} \mathrm{Tê}-y \ddot{u}$ (李德 裾), who was Premier to the Emperor Wu-tsung from 841 to 846 A.D., we find a private letter to the Emperor which was written some time after the destruction of the temples and monasteries. It was entitled: "Congratulations on the complete destruction of all the monasteries." In his letter Li Tê-yü says "two thousand of Ta-ch'in and Muhufa ceased to confuse the national customs and manners."

These two contemporary writings prove that there were at least over two thousand foreign missionaries throughout China at that time, including Nestorians and Mohammedans, whilst the way in which these two religions are mentioned-Ta-ch'in coming at the head of the two bodies-indicates also that the Nestorians were the stronger body of the two.

This fact alone is enough to prove-even were there no other proof-that it is no matter for surprise that as many as seventy names of Nestorian missionaries should be found carved on the monument of 781 A.D. 
When this Imperial Edict (which was chiefly aimed at What became the Buddhists) was enforced to the letter, the of the Nestorians in China? Nestorian Mission doubtless also received a Syriac Church in China, being naturally mixed up with the mass of the Chinese population, disappeared. But did they disappear so completely as to leave no traces whatever behind them ?

This is the most important question of all in the study of the Inscription, and we are glad to announce that we have discovered some remnants of the Assyrian Christians in China.

After the severe blow they received in the ninth century, the Chinese Nestorians gradually might become amalgamated with the Chinese Mohammedans, and this absorption into the Mohammedan body might have been completed in the fourteenth century through the great persecution which Timur, "the Scourge of Asia," directed against both Nestorians and Mohammedans.

As for the foreign missionaries who survived the Emperor Wu-tsung's persecution in the year 845 A.D., some remained in China, but most wandered back westward, and reached the nearest sees of the Assyrian Church in Western Turkestan. The Chinese Christians who did not join the Mohammedan body may be found among the "Secret Societies," of which about ten are known at the present day, viz. (1) Fa-lu Chiao (法 路教), i.e. the teaching of Fa-lu; (2) T'ai-yang Chiao (太陽教), i.e. Sun-teaching, or Sun-religion; (3) Paiyün Chiao (白䨐呚), i.e. White-cloud religion; (4) Chaokuang Chiao (朝光郄), i.e. Morning-Light-worshipping Society; (5) Wu-wei Chiao (無焦教), i.e. Non-action religion; (6) Ssŭ-ch'uan Province Sect (四川 呚) or Chin-tan Chiao(金丹敎), i.e. the Religion of the Pill of Immortality; (7) Pai-lien Chiao (白蓮教), i.e. White Lily Sect; (8) Pakua Chiao (入卦教), i.e. Eight Diagrams Society ; (9) Tzŭmu Chiao (子皮教), i.e. Mother and Son Society; (10) 
Shêng-hsien Chiao (聖仙教), i.e. Religion of the Sages and Worthies.

Of these ten secret societies, the Chin-tan Chiao (金 丹 呚), the "Religion of the Pill of Immortality," is decidedly Christian in character, and that it is a relic of the Nestorians who set up our Monument we are convinced from both internal and external evidence. How the Chin-tan Chiao believers represent the Nestorians we shall explain hereafter, but that the greater part of the Nestorians, after the middle of the ninth century, became gradually amalgamated with Chinese Mohammedans, we have the following grounds for believing.

According to the Rev. H. V. Noyes and Mr. Navarra (the author of "China und die Chinesen") there are now about 20 millions of Mohammedans throughout China proper.* In the province of Kansu alone there are over 8 millions; in the province of Shensi about 7 millions; and in Honan 2 millions.

The presence of so many Mohammedans in China at the present day cannot be accounted for unless this Nestorian amalgamation was completed by the fourteenth century.

Causes for the amalgamation are not far to seek. Different and intolerant as were their creeds, the people themselves who embraced the two religions were very much alike both in race and language, whilst they were fellow-sufferers for their respective faiths.

And not only so. What actually did take place three hundred years ago on the part of Queen Elizabeth and the Sultan Murad Khan, must have occurred several centuries before in China on the part of the Nestorians and Mohammedans,

* The Rev. A. C. Moule writes : "Broomhall, in his 'Islam in China,' 1910, p. 215, has reduced the Moslem population to 10,000,000 at most, and d'Ollone, in his 'Recherches sur les Musulmans Chinois,' 1911, p. 430, to 4,000,000 or less ; the latter being, on the whole, the more 'expert' opinion of the two, while both are estimates and not the result of a census."

The general opinion, however, amongst the Japanese experts on the subject favours the estimates given here. 
as both of them were equally opposed to the perverted doctrine of the Trinity-Father, Mother (i.e. Mary) and Son - the false doctrine and gross conception of the Trinity, as then taught by certain Christians. Neither Nestorians nor Muslims could bear to see the human mother Mary worshipped as the Mother of the Ineffable God.

Prof. Max Müller says in his "Last Essays" (on Mohammedanism and Christianity) that "Queen Elizabeth, when arranging a treaty with Sultan Murad Khan, stated that she was the Defender of the Faith against those who have falsely usurped the name of Christ, and that Protestants and Mohammedans alike were haters of idolatry.

"Her ambassador was still more outspoken, for he wrote on the 9th of November, 1587: 'Since God alone protects His own, He will so punish these idolaters (i.e. the Spaniards) through us, that they who survive will be converted by their example to worship with us the True God, and you, fighting for this glory, will heap up victory and all other good things.'

"The same sentiments were expressed on the part of the Sublime Porte, by Sinan Pasha, who about the same time told the Roman ambassador that to be good Mussulmans all that was wanting to the English was that they raise a finger and pronounced the Eshed, or Confession of Faith. The real difference between Islam and Christianity was considered so small by the Mohammedans themselves, that at a later time we find another Turkish ambassador, Ahmed Rasmi Effendi, assuring Frederick the Great that they considered Protestants as Mohammedans in disguise " "Last Essáys," pp. 242-243).

Although there is no evidence for saying that Mohammed himself ever was a Christian, his feelings at first were evidently more friendly towards the Christians than towards the Jews. He declares, "Thou wilt surely find that the strongest in enmity against those who believe are the Jews and the idolaters, and thou wilt find the nearest in love to those who believe to be those who say, 'We are Christians'; that is 
because there are amongst them priests and monks, and because they are not proud."

The Nestorian Patriarchs were already basking in the favour of the Mohammedan Khaliph at Bagdad at the close of the eighth century-Khaliph Harun-al-Rashid of whom we so often hear in the famous "Arabian Nights' Entertainments" -whilst their missionaries were much helped by the Mohammedans all along the caravan-route to China after 635 A.D.

The Syrian monk A-lo-pên (阿 羅 本) and his party) followed in the wake of the Mohammedan mission which reached China in 628 A.D. or in 632 A.D.

According to Dabry de Thiersant, the author of the book called "Mahometanisme en Chine" (see pp. 86, 87), in the year 628 A.D. a Mohammedan named Wah Abi Kobsha had audience with the Emperor T'ai-tsung in Hsian-fu and was allowed to build a mosque. He returned to Arabia in 632 to reinforce that mission. In 742 A.D. there were already over five thousand Mohammedans in China.

In 755 A.D., when the notorious An Lu-shan (安旋 山) rebelled and carried all before him and the throne of the T'ang Dynasty was in imminent danger, 4000 Uigurs were invited by the Chinese Emperor to serve as Imperial mercenaries. They fought so well that they finally won the day.

Although we cannot be sure whether these 4000 Uigurs were Mohammedans or Nestorians, we know that they belonged to the mixed tribes who used a Syriac system of writing, as appears from the recent discoveries of Sir Aurel Stein and the Rev. Z. Tachibana of the Honganji temple of Kyoto.

These facts show that there were many Mohammedans in * China during the eighth and ninth centuries. But twenty-one millions, or more, of Mohammedans in China at the beginning of the twentieth century is altogether too many to be accounted for by their natural and gradual increase in ten centuries.

We must find some other reason to explain this

* See the footnote on p. 49. 
extraordinary number of them. Knowing that it was the Nestorians who first introduced the Græco-Roman civilization into Arabia ; that, later, both Nestorians and Mohammedans in Persia worked together, hand in hand, before either of them reached China in the seventh century; ${ }^{*}$ and that even after the Saracenic power was established in Persia, the Nestorian churches throve under the Khaliphate, we are led to surmise that the Nestorians must have been drawn still closer to the Mohammedans as a result of the Emperor Wu-tsung's persecution in 845 A.D. and the still fiercer persecution of Timur in the fourteenth century.

Both the Emperor Wu-Tsung and Timur equally detested the Mohammedans and Nestorians, but. Timur persecuted the Mohammedans even more severely than the Nestorians.

After Timur, do we find any Nestorians in China? No! but what we do find is the enormous number of twenty-one millions of Mohammedans. Why should there be so many Mohammedans and yet no Nestorians?

This question no one can answer very easily. Our theory is that the stronger Mohammedan body swallowed up the weaker Nestorians. The minority had to conform to the majority on account of the external pressure.

After the death of Yahbh-alaha III., of Uigur origin, who was Nestorian Patriarch at Bagdad from 1281 A.D. to 1317 A.D., Christian influence gradually declined until all trace of it in Chinese history is lost. So that unless that immense body of Mohammedans now in China is, so to speak, a

* We read in the letter of the Patriarch Ishu-yabh III. (648-660) that the conduct of the Mohammedans was in general kindly toward the Nestorians. (Cf. p. xc., note 2, vol. I., "Cathay and the Way Thither.") Again we read Gibbon's words, "To his Christian subjects, Mahomet readily granted the security of their persons, the freedom of their trade, the property of their goods, and the toleration of their worship." (See Chapter L., "The Decline and Fall of the Roman Empirc.") "During the first age of the conquest, they suspected the loyalty of Catholics, whose name of Melchites betrayed their secret attach. ment to the Greek emperor, while the Nestorians and Jacobites approved themselves the sincere and voluntary friends of the Mahometan governinent." (See Chapter LI.) 
metamorphosis of the Nestorians, who were so influential prior to the ninth century, what could have become of them?

Accordingly, we take the existence of over twenty-one millions of Mohammedans in China as one of the external evidences which indicate that there must have been a very large body of Nestorians when our Monument was set up in A.D. 781 .

But even should this be denied, we can yet find traces The Chin-tan of the Nestorians among the secret sects of China.

Chiao, a

"Secret

Soclety,"

and the

Nestorians.

Among the ten secret societies known to us, the Chin-tan Chiao (金丹教), or "Religion of the Pill of Immortality," may be identified with the ancient Nestorian body in China.

To describe what the Chin-tan Chiao is, we cannot do better than quote the well-known missionary, Dr. Timothy Richard, who says :

“The Kin Tan Kiao (金丹教), the Religion of the Pill of Immortality, is perhaps the most widespread and powerful of all the secret societies in the North of China, and deserves a more extended notice. It is to be found in Szechuan, Shensi, Shansi, Honan, Shantung, in the borders of Mongolia, and in Manchuria. In the last few years in Mongolia most of the disaffected people have been joining it, as it is their only hope from the oppression of the Mandarins. Although the sect is not political, it is obliged under persecution to take joint measures for self-defence. The pity is, every powerful combination against the Mandarins is regarded by them as rebellion. The Government massacred i 5,000 of these Kin Tan Kiao believers in $189 \mathrm{I}$ under the false charge of being rebels, if we are to credit good men who were living in the midst of the troubles.

"The Taoists talked of having discovered the Pill of Immortality some centuries before the time of Christ, but for about a thousand years they only sought for it in minerals, 
herbs and other physical essences as remedies against disease and death.

"But in A.D. 755 was born a man named Lü Yen

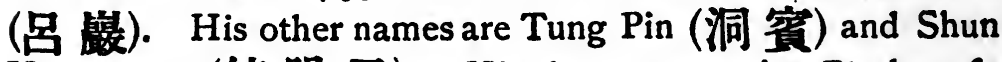
Yang-tsze (純陽子). His home was in P'uchow-fu (蒲 州 府) in the south of Shansi. He attained the degree of Doctor of Literature (Chin-shih) (進 \pm ), and subsequently held office in the province of Kiang-si (江 西). This man was a voluminous writer on religion, and put the search for immortality on a moral and spiritual basis, largely using the old physical terms of Yin (陰) and Yang (陽), but with a new and higher meaning, and so called himself 'Son of the Essence of the Universe'! He did not profess to have discovered this new truth himself, but to have received it, transmitted from the first and greatest of the 'Eight Im. mortals' (八仙), who lived about seven centuries before him. The real name of this one does not seem to be given, but the symbolical ones are 'The Warning Bell, which does not trust physical force' (鍾離權); 'The Quiet Logos' (寂道); 'The King of the Sons of God' (王晹子); 'The First Teacher of the True Doctrine of Immortality' (長生真訣), and 'Teacher from Above' (雲房先生); and there are other important truths not indicated in these names which remind us strongly of Christian truth.

"The question of supreme importance here is this: Did there live at that period any other teacher in the whole world who taught such transcendent truths, but one-Jesus of Nazareth ? We have not yet heard of any other, and if it was transmitted from Western Asia then the question is, how did Lu Yen (呂 縀) get hold of these doctrínes?

"A little history and geography will help us here. The Nestorian missionaries were received by the Chinese Emperor in Hsian-fu in A.D. 635, and permitted to settle down and teach their religion. The famous general, Kwo Tsze-yih (郭子儀), the prince of Fên-yang (汾陽王) in Shansi, 
became $a$ believer in the Nestorian religion, and he lived A.D. 697-781. From the Nestorian Monument we see that the Nestorian missionaries used Chinese philosophical terms then current to express Christian truths, just as we borrow many religious terms in our days. As the Christian religion was patronized in the capital, and by one of the most powerful princes of the day, and as this had now gone on for more than a century, we have ample time for a number of adherents to become thorough followers of Nestorianism in this region. Now Lü Yen was brought up in this very centre between the capital Hsian-fu and P'ing-yang $F u$, so there seems to have been ample opportunity for him to get hold of these doctrines from the West.

"This doctrine, whatever its origin may have been, has taken a great hold in China. Temples to Shun-yang-tsze, i.e. Lü Yen, are all over North and Central China at least, and are the places much resorted to for healing by faith and prayer and for superhuman guidance; the doctrine is also often associated with the Buddhist Mi-mi'-kiao (密教), which is extensively known in the north with Kuan-yin (觀 音), the Goddess of Mercy, in whose worship Mr. Beal has proved the prayers in use are essentially the same as the Christians' prayers. (See 'Catena of Buddhist Scriptures,' by Rev. S. Beal.)

"Moreover, the Manchu Dynasty has forbidden the image as formerly to be made with a white face. If the white face indicates foreign origin then the step is clear. If not, it is difficult that the Government should concern itself about what otherwise would be of such a trifling importance.

"Add to this circumstantial evidence that several of the leaders of the Kin Tan Kiao, whether they have joined the modern Christians or not, have decided that the essential doctrines of the Kin Tan Kiao and Christianity are the same.

"In the absence then of strong evidence to the contrary, 
there is very strong presumption that much of the teaching of this Kin Tan Kiao, like the highest teaching in Buddhism, had its origin in Christianity. And if not, we have yet to look for the lost Nestorians, and our theory of the irresistible power of Christian truth will require some modification.

"How is it then that we do not find the Christian scriptures amongst them?

"One easy answer to this lies in the anti-foreign tradition of ages that is going on in the Chinese government, arising largely no doubt from Confucianism being a national instead of a universal religion. Anything that appeals to any power above the Emperor is regarded as treasonable, and, therefore according to this law, books containing these sentiments or those which have anything clearly expressed in terms not current amongst other recognized religions of China, have been destroyed again and again, times without number, for a millennium, and this is going on even now, and their leaders are put to death, and their property confiscated. Yet in spite of being hunted and hounded for ages they still thrive, and new martyrs are ripe and ready in every age to risk property, home, and their very lives for the truth they have!" ("The China Mission Handbook for 1896," pp. 43-45.)

To what Dr. Timothy Richard says, we venture to add that Lü Yen (呂 度), the founder of the Chin-tan Chiao, was no other person than L ï Hsiu-yen (呂秀绻), the Chinese scholar who wrote the Chinese ideographs on the Nestorian Stone for Ching-ching (景淨), Adam, the author of the Inscription!

Lü Hsiu-yen, the penman of the Inscription, ever since the discovery of the stone in 1623 A.D., has been a mystery which has baffled every attempt of the scholars, Chinese and foreign, who have tried their hands on the Inscription. Strange to say, in spite of its. extraordinarily beautiful writing-for even its abnormal form of some Chinese characters have always been quoted as the model of good 
handwriting-nothing was ever known about this Chinaman, Lï Hsiu-yen (呂秀管). Neither in the field of "Stone and Metal" writings, nor in the lists of the Chinese officials of the T'ang Dynasty do we find the name of $L \ddot{u}$ Hsiu-yen. This is very strange indeed, since Lü Hsiu-yen as a calligrapher, could vie with any of the first-class penmen or calligraphers of the time, such as Ch'u Sui-liang (禇通良), Ou-yang Hsün (歐陽詢), and others.

Another point we must notice is that Lü Hsiu-yen, the writer of the Nestorian Inscription, had the court rank of “Chao-i-Lang-ch'ien-hang” (朝議郎前行), which corresponds to “T's'ung-liu-p'in-hsia” (膲六品下), the Lower Sixth Rank, whilst as "T'ai-chou-ssŭ-shih-ts'an-chün" (台州司士寥軍) he cannot have enjoyed a higher rank than that of the Lower Seventh Rank (從七品下) according to the official proceedings preserved in the book called "Six Codes. of the Great T'ang" (大唐六典). This shows that officially he was of comparatively high rank. He was a local official whose duty was to look after ports, canals, vehicles, inns and the general industry of the T'aichou District, Chekiang Province (Kiangnan), standing at the foot of Mount T'ien-t'ai (天台山), the great seat of the White-lotus-sect of Buddhism, whither our Dengyo Daishi went to study in A.D. 804.

That $L \ddot{u}$ Hsiu-yen enjoyed comparatively high official rank shows that he was a promising young man, who had done exceptionally well at his Civil Service examination, and also that he must have been between I9 and 30 years of age because to pass the examination at ig years of age was supposed to show uncommon ability, as we learn from the famous case of the well-known Han Yü (韓愈).

Such a good calligrapher, which in China always implies good scholarship, with such a comparatively high rank, could not have been employed as a local official unless he had been a young man in his twenties. Moreover, the style and 
character of the writing declare to the experienced eye that the writing of the Inscription was not done by an old man.

And again, T'ai Chou 台州 (now T'ai-chou fu 台州府) was a department in the eastern portion of Chekiang (断江東道), which was itself part of the province of Eastern Chiang-nan (江南東道), which comprised parts or the whole of the modern provinces of Kiangsu, Chekiang, Fukien, etc. Lü Yen is said to have held office at P'ên-ch'êng 溢城 (now Tê-hua 德化 in Chiu-chiang in the province of Kiangsi) in Western Chiang-nan (江南西道); and so, speaking in a general manner, he and Lü Hsiu-yen may both be said to have held office in the province of Chiang-nan.

Now compare all these facts with those concerning $\mathrm{Lü}$ Yen (呂榐), the originator of the Chin-tan Chiao (金丹教), who was born on the 29th of May in 755 A.D., the last year of the Emperor Hsuian-Tsung (立宗), the Augustan Age of the T'ang Dynasty. L Li Yen must have been 25 years old in the year 781 A.D. (February $4^{\text {th }}$ ) when the Nestorian Monument was set up, and if he wrote the Inscription (as we affirm) it agrees with the expert opinion of famous calligraphers who say that the writing is the work of a young man.

If Lü Yen, the founder of the Chin-tan Chiao sect, held his office somewhere in the Province of Kiangsi (江 西), this does not disagree with the fact that Lü Hsiu-yen (呂秀侮), the writer of the Inscription, was a local official of T'ai-chou, in the Province of Kiangnan (江 南), in which the Chekiang province once was included.

If we compare the name Lü Yen (呂 Lü Hsiu-yen (呂秀臀), we find indeed that the middle character "hsiu" (秀) is missing. But if we bear in mind that prior to A.D. 932 most of the books in China were written by hand, printing not being in fashion in China, and that printed books are exceedingly scarce even in the early 
period of the Sung Dynasty (960-1279 A.D.), we can easily see how the name of Lü Hsiu-yen (呂秀臀) was left to the mercy of transcribers for several hundred years.

Besides, it is a well-known fact that names are very often cut short in Chinese books either to suit the occasion or the writers' own purpose. For instance, the name of the famous statesman of Chou, Chü Po-yü (遮伯玉) was shortened by omitting the middle character, and he was known as Chü Yü (滤玉). Again that of Su Tzŭ-tan (蘇子䐳) was shortened by omitting the middle character, and was knownas Su Tan(蘇膽), whilst Tung Ch'i-ch'ang(黄其昌), the famous writer of the Ming Era, was frequently known as Tung Ch'ang (董昌). This omission of the middle character was so common that after many years people could not tell which was the right form of the personal names.

Mr. Ch'ien (銭 大肵), a great authority on Chinese orthography, once said in his book on "Writing" (食新 錄) : "Strange as it may seem to us, the cutting or dividing as well as the omitting of the personal names has been a long. established custom since the Han and Wei Eras. This was never thought strange."

From these facts it is no wonder if Lü Hsiu-yen, the full name of the writer of the Inscription, should be written Lui Yen, the name of the founder of the Chin-tan Chiao; and it is plain that "Lü Yen," whose name is so well known as the originator of the Chin-tan Chiao, as a poet, and as a great master of calligraphy * besides, was really "Lü Hsiu-yen" who wrote the ideographs of the Inscription.

Anyhow, in the year 781 A.D. there were two namesLü Yen (呂蒋) and Lï Hsiu-yen (呂秀臀). The former is found in the books published several centuries later, whilst the latter occurs in the Inscription itself written by that very person who lived at that very time. We shall therefore be

* That he was a poet and a great master of calligraphy may clearly be seen from his biography by the four authors we mention here as well as from any good Dictionary of the Chinese Cursive Style (草替字整). 
justified in correcting the book-name by that which is preserved on the "Speaking Stone," if our theory prove true.

Moreover, we may refer to four writers on the life of Lü Yen (呂㵏). (I) Hsin Wên-fang (辛文房), a Chinaman of Uigur extraction who lived between 1276 A.D. and 1367 A.D., and wrote a book called "The Biography of the Illustrious Men and Women of the T'ang Era” (唐才子 傳), in which he dealt at length with Lü Yen. (2) In the year 157 I A.D., Wang Shih-chên (王世貞) again treated the life of Lü Yen in a book called "The Biographical History of the Chinese Sages and Hermits" (列仙全傳), whilst in I 579 A.D. (3) Ling Chih-chê (凌稚哲) gave a short but most authentic sketch of the life of Lü Yen in a book called "The Authentic Biography of the Personal Names of China" (萬姓統譜). (4) The last, but not the least, of all, Liu T'i-shu (埕體 恕), in the year 1742 A.D., edited what is now commonly called "The Complete Works of Lü Yen” (呂祖全書), the Founder of the Chin-tan Chiao (金丹教).

All these writers with the exception of Hsin Wên-fang agree in saying that $L \ddot{u}$ Yen, the founder of the sect, was known by the nickname of "Hui-Tao-Chên-Jên" (包道䢐人), or “Hui-Tao-Chên-Shih” (可道䢐士), which means "The True Man of Islam." *

But, if he were really a Mohammedan, why should he be so nicknamed? and if he was a true Mohammedan, what reason had he for founding the Chin-tan Chiao? The fact that he had originated the Chin-tan Chiao shows that he was not "The True Man of Islam," as recorded to have been by the writers of the sixteenth and eighteenth centuries-writers who were born at a time when the name of the "Luminous Religion" (i.e. Nestorianism in China) was entirely forgotten and only the name of Islam remained.

* To many it will seem that this is obviously a Taoist appellation, meaning "The Pure Man who has reverted to Tao." 
Besides these external evidences, we have some internal ones to prove that Lü Yen, the founder of the Chin-tan Chiao, was Lü Hsiu-yen, the Penman of the Nestorian Inscription, and that the Chin-tan Chiao is the present form of the old Nestorian Church in China.

Our evidences are all taken from the "Complete Works of Liu Yen" spoken of above. In the second volume of the book, which is devoted to "The Miracles of Master L $\ddot{u}$ Yen," we read how he changed the water into wine so that he might give a good drink to his disciples, and how a dead fish was revived by his touch. We read also how he healed the sick and the wounded; how a poor man suffering from paralysis was cured by him, and how the blind recovered sight by his touch.

Whence came all these stories? Are they mere coincidences? If we read the liturgical part of the book, we are compelled to doubt this, for there we find a fragment of the Chin-tan Chiao Liturgy which resembles the Nestorian Liturgy found by Prof. Paul Pelliot at Sha-chou in 1908; whilst the Chin-tan Chiao has Diptychs like those of the Syrian Church.

We may feel pretty sure that it was the descendants of the Chinese Nestorians who were so pitilessly massacred by the Chinese soldiery in 1891. Those 15,000 Chinese Chin$\tan$ Chiao believers who were massacred were unknown brethren of the poor Armenian Christians who were cruelly massacred about the same time in the Nearer East.

Suppose, for a moment, that the foreign elements in the The Persian Chinese language as well as those found in the visit recorded
in the Annals of old Japan. to establish the fact of overland communication between China and the classical countries on the Mediterranean, we have knowledge of the visit of Persians to Japan, who came by way of Hsi-an-fu, the capital of China. In the Ancient Chronicle of Japan we find that "in the year 
736 A.D., in. the seventh month, an Imperial audience was granted to the Japanese embassy who returned from $T^{\prime}$ 'ang (i.e. China) together with three Chinese and one Persian."

Again, "In the eleventh month, the Emperor granted Court favours to those who recently returned from T'ang; Naka-tomi-no-asomi (中臣朝臣), the Envoy to the Chinese Court, was promoted two ranks from the lower fifth grade of Court-rank to the lower fourth of the same, whilst the two Chinamen-Huang $P^{\prime} u$ (皇浦) and $T^{\prime}$ ang Chang (唐張) as well as the Persian called "Li-mi-i (李密 and others were respectively granted Imperial favours." (See the "Imperial Chronicles of Japan" written in 797 A.D.)

Who and what was this Persian stranger named Li-mi-i (李密醫) nobody knows. That the name should be "Milis, the physician," is our humble surmise. In the first place " $i$ " (登) in the name, stands for "medicine." No easier or more natural mistake would be made by a Chinese or Japanese in transcribing “密李” (Mili) than to make it “李密” (Li-mi), for the latter is the regular form of a Chinese personal name, whilst the former is not. So, left to his own discretion, the scribe might either carelessly, or tentatively, transpose the Chinese characters “密李” for "Mili" into "Li-mi" (李密), which would not be unnatural seeing that in Chinese there are very many " $\mathrm{Li}$-mi" just as there are many "Milis" in Persian.

"Li-mi" must have been well off and enjoyed high rank in the Chinese capital to be so well received on coming to Japan. Who knows whether this Persian "Li-mi" (Mili), the physician, who visited Nara, the capital of Japan, in 736 A.D. was not the Priest of "Royal Balkh," and father of Yesbuzid, the Chorepiscopos, who erected the renowned Nestorian Stone in $78 \mathrm{I}$ A.D. somewhere in the neighbourhood of Ch'ang-an?

Moreover, two pieces of incense-wood are exhibited at the Imperial Museum, Uyeno, Tokyo. Their history may be 


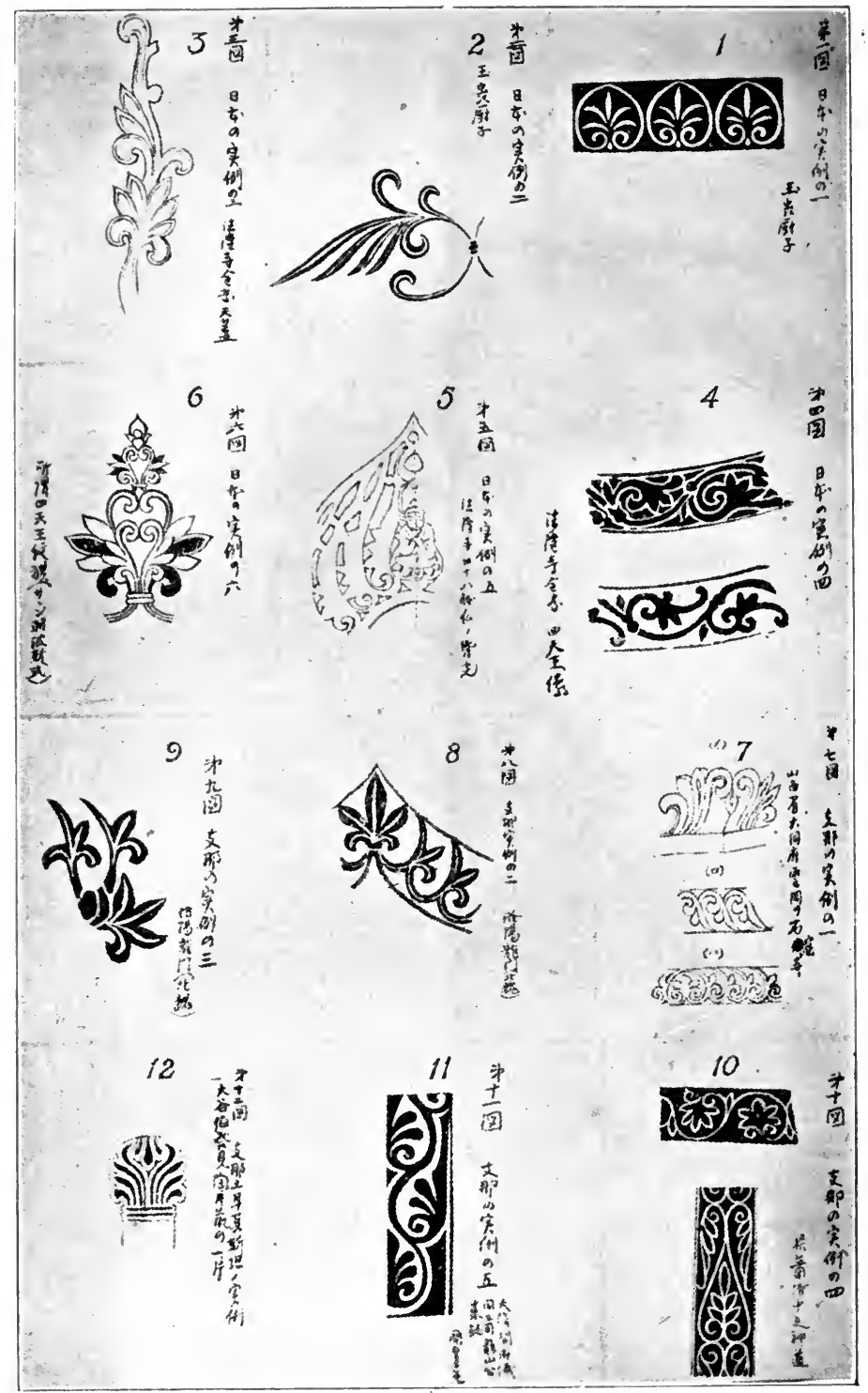

SPECIMENS OF 'THE “HONEYSUCKLE" PATTERN FROM JAPANESE (1-6) AND CHINESE (7-12) BUILDINGS.

[To face p. 63 . 
older than the eighth century, for we can trace them as far back as 78I A.D. An official document of Japan says that "on the third of the second moon, 781 A.D., the weight of these two pieces of Incense wood was examined by the Imperial Order and an account thereof kept."

This incense-wood, therefore, is at least as old as the Nestorian Monument! And, strange to say, both pieces are inscribed with a mysterious writing, which was long thought to be either Korean or some mystical script ; but Prof. A. H. Sayce and Dr. Cowley of Oxford now pronounce it to be in a form of the Syriac alphabet.

That the "honey-suckle" design found in Japanese art of the Nara period (687-783 A.D.) is derived from Greek, or more particularly Syro-Byzantine art, has been pointed out by Dr. Ito, Professor of Architecture in the Imperial University of Tokyo, to whom we are indebted for the valuable information to prove this point.

Again, the Adoration of the Magi is a favourite scene in Early Christian art; the Magi are represented in Persian costume with tight hose and "Phrygian caps," which are pointed caps with their apex turned toward the front.

But "Phrygian caps" are seen in frescoes of the seventh and eighth centuries discovered recently by Sir Aurel Stein, as well as by the Rev. Z. Tachibana in Central Asia, whilst common pictures we see in Japan show that a Japanese farmer of the eighth century had a "Phrygian cap" on.

"Even the buckle, with the help of which the pre-historic Greek fastened his cloak," says Prof. Sayce, "has been shown by a German scholar to imply an arrangement of the dress such as we see represented on the Hittites' monument of Ibreez" ("The Hittites," p. 120, by Prof. A. H. Sayce).

Strange to say, this buckle is also one of the conspicuous features of Buddhistic Art in the Middle Ages to be seen in the costumes of Buddhistic statues introduced into Japan from China prior to the eighth century A.D. The twelve 
statues of Uzumasa, Kyoto, are very good examples which illustrate this fact. Indeed, the buckle supplies us with a clue whereby to decide the age in which an image was made. To speak more plainly, the buckle is not found in Buddhist art later than the ninth century. This fact clearly shows that the buckle is a foreign object which came to Japan from China before it came for the second time by way of the Cape of Good Hope in the sixteenth century.

Again, what Prof. Sayce says about the famous lions of Mykenæ may well be quoted here to prove that the Landbridge had existed long before between Korea, China, and the countries of the Mediterranean. He says :

"Perhaps, however, the most striking illustration of the Westward migration of Hittite influence, is to be found in the famous lions which stand fronting each other, carved on stone, above the great gate of the ancient Peloponnesian city. The lions of Mykenæ have long been known as the oldest piece of sculpture in Europe, but the art which inspired it was of Hittite origin. A similar bas-relief has been discovered at Kumbet, in Phrygia, in the near vicinity of Hittite monuments; and we have just seen that the heraldic position in which lions are represented was a peculiar feature of Hittite art" ("The Hittites," p. 120).

The lion itself was never found in the insular Empire of Japan, nor did it exist in the Korean Peninsula, not to speak of China ; and yet "the lions which stand fronting each other, carved on stone" are the guardians to be seen everywhere at the entrance of a shrine in Japan. The old Japanese name for them is "Korean Dogs"; and these Korean Dogs guard in the Throne in the Ancient Imperial Palace of Kyoto. But in Korea these "Korean Dogs" are known as "Chinese Lions," whilst in China itself they are called "Persian Lions."

These and other facts prove that overland communication did exist between Syria and China sufficiently to permit of the coming of the Nestorian missionaries to China in 635 A.D., and 
it is no wonder that they brought their incense-wood to Japan within a century after their arrival at the capital of China.

According to the book lately published by the great Prof. Paul Chinese authority, the late Prof. Lo Chên-yü Pelliot's
discovery at (羅 振 玉), of the Peking University, Prof. Pelliot

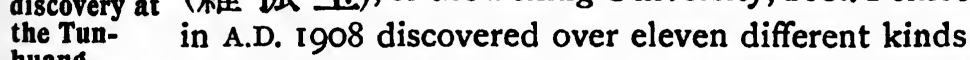
huang Library. of old books and fragments of ancient documents at the Tun-huang Stone Cave, i.e. Library (敦煌石室), Sha-chou (沙 州), an historic old town in the Oasis, about one hundred miles off the present main caravan road from the Western Regions whose terminus is Hsi-an-fu, the ancient capital of China.

Besides several fragments of Buddhist scriptures, there were a few Mohammedan and Manichean writings. Above all, some Nestorian writings in Chinese were discovered, of which, most fortunately, two pieces are almost complete. One, entitled "Ching chiao San-wei-mêng-tu Tsan" (景呚三威蒙度讃), is “The Nestorian Baptismal Hymn to the "irinity"; the other called "Tsun-ching," i.e. literally, "Praise-sutra" (拿經), may well be named "The Nestorian Book of Praise, dedicated to the Living and the Dead." In other words, this "Tsun-ching" of the Chinese Nestorians exactly corresponds to the Nestorian Diptychs, i.e. "The Memento," or list of living benefactors, as well as of the dead who were commemorated in the Divine Liturgy, and whose names were inscribed on the two-leaved ivory tablets.

The Nestorian Diptychs are well preserved in the Weip'ai, I-hai in Japanese (位. 牌), or Ling-p'ai, Rei-hai in Japanese (缽牌), of Japanese Buddhism, which give the date of death and the soul-name of the departed (Hotoke or Mitama). They were unknown in the old Hinayana Buddhism of India.

The following translation of the Hymn and the Diptychs 
will enable the student to judge for himself as to the value of Prof. Pelliot's discovery in 1908.*

(I) "Nestorian Baptismal Hymn in Adoration of the Trinity."

"All the angels in the highest profoundly adore Thee!

The whole earth rejoices in universal peace and good-will. In the beginning Man received the true Divine nature From the Three Powers (Heaven, Earth, and Man). All the Saints adore Thee, Most Merciful God, Our Father! All the Enlightened praise Thee!

All who seek Truth take refuge in Thee.

Looking up we receive The gracious light

And are freed from evil spirits that we may seek the lost. Oh, true Eternal and Merciful Father!

O Glorious Son!

O Pure Spirit!

Triune God!

Thou rulest over all the Kings of earth.

Thou art the Spiritual Emperor among all World-honoured Ones,

Dwelling in Divine light of boundless effulgence.

Visible only (to the Saints),

For no mortal eyes have seen Thee,

Nor can any one describe Thy glorious Form,

For Thy holiness is beyond description.

Thy Divine Majesty is matchless,

Only Thou art changeless.

Thou art the Root of all goodness,

And Thy goodness is boundless.

Now when I consider all Thy grace and goodness Which gladdens this country with the music (of the Gospel),

- The translation of this Hymn and that of the Nestorian Diptychs given on page 67 , as well as the identification of the names, etc., are the Author's own and he himself is alone responsible. 
O Messiah! Thou greatest and holiest of Beings,

Who savest innumerable souls from the sorrows of life.

O Eternal King!

O merciful Lamb of God!

Who greatly pitieth all suffering ones,

Who dreadest no Cross.

We pray Thee remove the heavy sins of men;

Let them recover their true original nature ;

Let them attain the perfection of the Son of God

Who stands on the right hand of the Father,

And whose Throne is above that of the greatest Prophets.

We pray Thee that all who are on the Salvation Raft may be saved from fire!

Great Pilot, Thou art our Merciful Father,

The great Prophet of our Holy Lord,

Our great King,

Who art able to save all who have gone astray

By Thy wisdom.

Steadfastly we lift our eyes to Thee!

Revive us by Celestial favours (ashes, fertilizers, and 'Sweet dew')

And nourish our root of goodness.

$O$ Thou most merciful and most holy Messiah !

Pity us, O Father, whose mercy is like the Ocean.

$O$ Most Merciful and Meek Son (Holy One)

And Pure (Holy) Spirit who is embodied in our Lord Beyond all thought."

(II) "The Nestorian Diptychs."

"We praise Thee, Aloha, God-Father and Mysterious One; and we praise Thee, Messiah, the God-Son of the Father; and Lu-ho-ning-chü-sha (i.e. the Syriac 'Ruha-dekudsa,' the Holy Spirit), the Spirit that beareth witness.

"These Three Persons are One.

(Let us pray also for the memorial of) 
Catholicos John (瑜罕難法主)

Catholicos Luke (盧伽法王)

Catholicos Mar George (燇矩辭法王),*

Catholicos Matthew (明泰法王),

Catholicos Moses (牟世法王),

Catholicos Mahadad (多惠法王),

Catholicos Mar Sergius (景通法王),

Catholicos Paul (筫路法王),

Catholicos "Thousand-eyed" (千 腿法 王),

Catholicos Na-ning-i (郍箐逸法王),

Catholicos Simeon (珉艷法王),

Catholicos Mar Sergius (摩薩吉思法王),

Catholicos George (宜和吉思法王),

Catholicos Mar Buchus (摩沒吉思法王),

Catholicos Ts'ên-wên (Simeon?) (岑穩僧 法王),

Catholicos “Twenty-four saints” (甘四聖法王).

Catholicos Kennaya (憲難耶法王),

Catholicos Hosea (賀薩耶法王),

Catholicos Messiah (霖沙电法王),

Catholicos Silas (奖羅 法王),

Catholicos Gur (篗盧法王),

Catholicos Pao-hsin (Reward of Faith) (報信法王).

(Let us pray also for the Memorial of those who wrote the books called) :

The eternal-enlightenment-kingly-pleasure-sutra (The Lamp of the Sanctuary, etc.) (常 明皇樂經),

The explaining-origin-reaching-the-cause-sutra (De causa omnium causarum) (宣元至本 經),

The-aiming-at-the-origin-happy-pleasure-sutra (The Book of Jubilees) (志元安樂經),

- Some will perhaps prefer Prof. Pelliot's suggestion of Mark (Mo-chü-ssŭ) in place of Mar George, and David (To-hui) in place of Mahadad, and to render Fa-wang in every case by Saint rather than by Catholicos. Cf. Bulletin de C Ecole Française d' Extreme-Oricnt, 1908, p. 519. 
The Heavenly-treasure-sutra (The Book of Treasures) (天䆩藏經),

The Mahadad-sutra (The Book by Catholicos Mahadad) (多惠聖王 經),

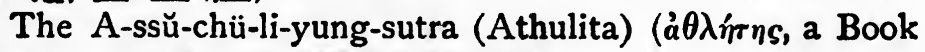
of Martyrs?) (阿思翟利容經),

On the causes of the Universe (渾元 經).

The thoroughly-understanding-the-truth-sutra (Refutation of heretical opinions?) (通畺 經),

The treasure-enlightenment-sutra (On the reason of the principal facts of the Church) (璸 明 經),

The Transmission-and-conversion-sutra (On Conversion) (傅 化 經),

The Book of Charity (整 遺 經),

The Original-Soul-sutra (A treatise on the soul) (原嚳 經),

The explained-briefly-sutra (The Book of Definition or Catechism) (述 略 經),

The Three-spheres sutra (On Genus, Species and Individuality) (三際 經),

The Signs-marks-sutra (徵詰 經) (Khuthama, i.e. Conclusion or sealing),

Hanan-Ishu Sutra (The Book by Catholicos Hanan-Ishu, or The Life of Hanan-Ishu, the Catholicos) (符 思 經),

The explained-meaning-sutra (A Solution of Various Difficult Questions) (宣 義 經),

Shih-li-hai Sutra (The Syriac "Shlikha " means "Apostle," so this must be Apostles' Creed) (師利 海 經),

Catholicos Paul Sutra (The Bcok by Catholicos Paul) (珼路法王 經),

Zacharia-sutra (The Book by Catholicos Zacharia) (删可律經),

George-sutra (The Boox by Catholicos George) (藝利月思經),

Ning-yeh-tun-sutra (A-nidha, i.e. a departed Christian; The Book of Burial Service?) (蜜耶 顄 經), 
I-tsê-lü-sutra ("Kash-kul," "containing all Book," i.e. Ceremony and Rule Book) (儀 則 律 經),

P'i-ê-ch'i-sutra (毗遏啓經),

The Nestorian Baptismal Hymn on the Trinity (Sanemad-praise-sutra) "San" is the Chinese for "three," whilst "emad" is the Syriac for "baptism," whilst "praise-sutra" stands for the word "hymn." So literally this means "the Three-baptismal-hymn" (三威算經),

Catholicos Moses-sutra (The Book by Catholicos Moses) (牟世法王經),

Elijah-sutra (伊利耶經),

Ephraim-sutra (遏拂林經),

Catholicos Pao-hsin Sutra (報信法王艖),

The Messiah, the Great independent Sovereign of the Universe-sutra (On the Incarnation of the Messiah, the great Lord of the Universe) (娓施訶自在天地經),

The Four-gates-sutra (四門經),

The Revelation (The revealed-truth-sutra) (啓真 經),

The Mar Sergius Sutra (The Book by Mar Sergius) (摩藻吉斯經),

The Tz'ú-li-po Sutra ("Tsuriha" stands for the "Cross" in Syriac, so this may be rendered "On the Doctrine of the Cross") (慈利波經),

The Wu-sha-na-sutra (鳥沙舥經).”

Fragmentary as these are, they are quite enough to con. vince any one of the fact that there was a strong body of Nestorians in China prior to the fourteenth century.

They had the Apostles' Creed in Chinese. They had a most beautiful baptismal hymn in Chinese. They had a book on the Incarnation of the Messiah. They had a book on the Doctrine of the Cross. In a word, they had all literature necessary for a living Church. Their ancestors

* It is fair to add that Prof. Pelliot hinsself renders the full title "Eloge des trois Majestés de la Religion Brillante du Ta-ts'in, par lesquelles on obtient lé salut." 
in the eighth century were powerful enough to erect a monument in the vicinity of Hsi-an-fu.

Who knows whether there were not many other scriptures besides these thirty-five books? Such as they are, these fragments agree with what we read in the Nestorian Inscription : "The Scriptures were translated in the Imperial library."

This discovery by Prof. Pelliot at Sha-chou (沙 州) in 1908 may be counted as strong evidence in favour of the genuineness of the stone against those who hold the erroneous idea of "the Jesuitical fabrication" of the Nestorian Monument.

The external or circumstantial evidences would be Internal worthless unless supported by internal evidences. Evidences. How far we may trust the external evidence greatly depends on the value of the internal evidence we can produce on the subject. But both internal and external evidence are alike useless to those extremely sceptical minds who decline to see anything if it militates against their own preconceived ideas. But to honest, sensible and independent thinkers the following evidences will certainly be convincing.

The first thing to note is an article contributed by Dr. Junjiro Takakusu, Professor of Sanskrit and Pali in the Imperial University of Tokyo, to “The T'oung Pao" (通 報) in 1896. What he wrote about King-tsing (i.e. Ching-ching) (景淨), Adam, the Persian priest who composed the Nestorian Inscription, is extremely interesting and very useful. He says :

"Now the same Adam (King-tsing), who composed the Inscription, is mentioned again in a Buddhist book, which in a way gives light on the activity of the Nestorian missionaries in China. While I was referring to the Buddhist canonical books of China the other day, I came across a book called the Chêng-yüan hsin-ting Shih-chiao Mu-lu 
(員元新定䆁教 $\mathrm{H}$ 錄), i.e. 'The New Catalogue of (the books of) teaching of Shakya in the period of Chengyüan' (A.D. 785-804), compiled by Yüan-chao (圆 炤), a priest of the Hsi-ming Monastery (西明寺). For this book see Bodleian Library, Japanese, 6500, Vol. VII, fol. 5 vo. In this I found a passage relating to the Nestorian missionary which I translate as follows :

"'Prajna, a Buddhist of Kapisa, N. India, travelled through Central India, Ceylon, and the Islands of the Southern Sea (Sumatra, Java, etc.) and came to China, for he had heard that Manjusri was in China.

" ' He arrived at Canton and came to the upper province (North) in A.D. 782. He translated together with King-tsing (景浄), Adam, a Persian priest of the monastery of Tats'in (Syria), the Satparamita-sutra from a $\mathrm{Hu}$ (胡) text," and finished translating seven volumes.

"'But because at that time Prajna was not familiar with the $\mathrm{Hu}$ language nor understood the Chinese language, and as King-tsing (Adam) did not know the Brahman language (Sanskrit), nor was versed in the teaching of Shakya, so, though they pretended to be translating the text, yet they could not, in reality, obtain a half of its gem (i.e. real meaning). They were seeking vainglory, privately and wrongly trying their luck.

"'They presented a memorial (to the Emperor) expecting to get it propagated.

"'The Emperor (Te-tsung, A.D. 780-804), who was intelligent, wise and accomplished, who revered the canon of the Shakya, examined what they had translated, and found that the principles contained in it were obscure and the wording was diffuse.

" Moreover, the Sangharama (monastery) of the Shakya

* The $H u$ text here mentioned must be the Uigur text into which the Sanskrit text had been translated. The Rev. Tachibana's discovery confirms this view. 
and the monastery of Ta-ts'in (Syria) differing much in their customs, and their religious practices being entirely opposed to each other, King-tsing (Adam) handed down the teaching of Mi-shi-ho (Messiah) (漏户訶), while the Shakyaputriya-Sramans propagated the Sutras of the Buddha. It is to be wished that the boundaries of the doctrines may be kept.distinct, and their followers may not intermingle. Orthodoxy and heterodoxy are different things, just as the rivers King and Wei have a different course.'

"So much for the extract from the book of Yuen-chau. As to the identity of Adam with King-tsing there is no doubt whatever, as the parallel texts of the Inscription clearly show.

"It is very interesting to have this little contemporary notice of the Nestorians from a Buddhist source.

"Christianity in China, in the seventh and thirteenth centuries, as Gibbon remarks in his famous history, is invincibly proved by the consent of Chinese, Arabian, Syriac, and Latin evidences. In addition to these we have now a reference made by an eye-witness in a Buddhist work. It was under the Emperor Te-tsung (A.D. 780-804) that King-tsing (Adam) had erected the Monument; under the same Emperor, he was recorded to have been translating a Buddhist Sutra.

"I have some doubt as to whether the translation took place before the erection of the Monument* or after it, though from what we read in the above extract, the translation seems to have been made after the Inscription. Prajna came to the upper province in A.D. 782, while the Monument was erected in A.D. 78r. But the year in which they were translating the Buddhist book is not given.

"Their united work however seems to have been stopped by an Edict, no doubt as a result of the jealousy of the

* The Monument was exected by Yesbuzid, Chorepiscopos of Kumdan. Adam, whose Chinese name was King-tsing (or Ching-ching) (棌), composed the Inscription. 
Buddhist priests. Te-tsung, the ruling Emperor, was claimed as a patron by both Buddhists and Nestorians, and was praised by both parties. It might have been so, as such has often been the case in China as well as in India. If we compare the statements of both parties we can easily understand the Emperor's attitude toward the Religions of his time.

"Adam, on his part, seems to have adopted many Buddhist terms in expressing himself. In the Inscription we find a number of Buddhistic expressions. He used the Buddhistic words or ideas for 'Monastery,' ' Priest,' etc., as Dr. Edkins has already remarked. This fact can now be explained as the result of King-tsing's study of Buddhism; for we have the evidence that he was engaged in translating Buddhist works.

"It was most natural for him to be anxious to get a knowledge of Buddhism in order to learn the right religious terms for expressing himself to the people.

"As to the characters representing 'Messiah' they are exactly the same as in the Inscription.

"We should like to know what has become of the book which Adam was translating. That sûtra is indeed preserved in the Buddhist canonical books, but it is ascribed entirely to his colleague Prajna (see No. 1004 'Nanjio Catalogue of the Chinese Tripitaka').

"Whether or not the translation is the same as that which was made by both together we cannot tell."

Short as it is, what Dr. Takakusu discovered in a Buddhist sûtra is sufficiently conclusive against those who hold erroneous opinions about our Monument.

We know for certain that Ching-ching (Adam), who composed the Inscription, as well as Lü Hsiu-yen, who wrote the Chinese characters for Adam, were real, historical personages. As for Ching-ching's rival or colleague, Prajna. it is perfectly well known amongst us Japanese that he was 
the very same "Kashmir" monk whom our Kobo-Daishi met in China during his stay in Hsi-an-fu and under whom he studied Sanskrit between A.D. 804-806.

Those who have observed the seventy-five or more names Seventy-flve in the Inscription, as well as on two sides of the
Names on the Stone. Monument, cannot fail to be impressed by its genuineness.

If we compare the Chinese characters used in representing the Syriac names in the Diptychs discovered by Prof. Pelliot in 1908 with those used on the Monument to denote the same names, we immediately note a marked difference between the writings in the point of age. We cannot but see that the Nestorian Stone belongs to the T'ang Era (618-907 A.D.), whilst the newly-discovered Diptychs are of a later Era-not earlier, in our opinion, than the fourteenth century. For instance : only the names "Aloha" (阿 羅 訶), “Messiah” (彌施訶), “Matthew” (明泰), use a common system of phonetic representations.

By comparing the following characters any observant eye will at once perceive that the one is far more classical than the other.

(Names in the Diptychs) (The names identified) (Names on the Stone)
(㡺 伽) Lu-chia . . . . Luke . . (利見) Li-chien

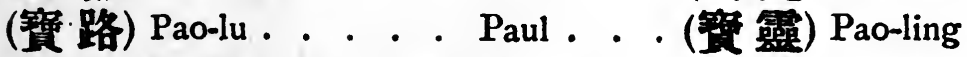
(宜和 吉思) I-ho-chi-ssŭ George . . (和 吉) Ho-chi
(遏拂林) Ê-fu-lin . . . Ephraim . (挮林) Fu-lin

We think that those mentioned in the Diptychs as the Catholicos Matthew and the Catholicos Mar Sergius are not the same Matthew and the same Mar Sergius whose names occur in "the Inscription, although the Chinese characters denoting them are the same.

Again Bishop Chi-lieh (及 烈), who is mentioned in the 
Inscription and possibly to be identified with Bishop Cyriacus, is also found in the contemporary Chinese annals.

"In 732 A.D., the King of Persia sent a chief named P'anna-mi (潘 那密) together with the Bishop Chi-lieh (及 烈); and this Bishop Chi-lieh was decorated with Imperial honours."

Then, again, we find the name "Fu-lin" (拂林) amongst the priests whose name "Ephraim" is given in Syriac.

Now, most curiously, this gives the clue to the Secret which many great Sinologists have so far failed to unravelwe mean the so-called "Fu-lin Mystery."

It is a well-known fact that in the Chinese histories and books of travel we often meet with "The Kingdom of Fu-lin" as an alternative name for "Ta-t'șin." In fact, the Kingdom of Ta-ch'in was first known as "Li-kan," then as "Ta-ch'in," and then again as "Fu-lin."

Concerning the so-called "Fu-lin Mystery" the opinions of three Sinologists may be briefly cited.

The first is "The Fulin-Polin theory" which, started by M. Jaquet, was strongly backed by Sir Henry Yule and M. Pauthier, and quite recently has found a great supporter in M. Chavannes (in the T'oung pao, May, 1908). They all agree in saying that the Chinese "Fu-lin" must be the corruption of the Greek word "Polin" (the City), by which Constantinople was meant, for, because of its splendid position and beautiful surroundings, Constantinople was spoken of as "The City" par excellence.

The second is "The Fulin-Bethlehem-theory," which Prof. Hirth started in his famous book "China and the Roman Orient." He says: "The old sound of the name Fu-lin may, therefore, be safely assumed to have been But-lim or But-lam. My interpretation of these words leads to the conclusion that the ancient country of Ta-ts'in called Fulin during the Middle Ages, was not the Roman Empire 
with Rome as capital, but merely its Oriental part, viz. Syria, Egypt, and Asia Minor."

And then he explains how Fu-lin came to be mixed up with Syria, saying: "Those messengers who came to China most naturally might have said, 'We come from the land where the Lord is born; and the Lord is born in Ta-ts'in,' they may have also said: 'We come from the land where the Lord is born; and the Lord is born in Bethlehem;' the sound of which name could not be better represented than by the two syllables which constitute the name Fulin, then pronounced But-lin. To see the name of the town of Bethlehem as the birthplace of the Messiah extended to the country to which it belongs, is by no means singular if we consider that this was done by religious enthusiasts who must have thought it a great privilege to come from the Holy Land. Moreover, the fact would be in perfect analogy with the Buddhistic usage according to which the name Magadha (摩仂陀), originally the birthplace of Buddha, was applied to the whole of India during the T'ang dynasty." ("China and the Roman Orient," pp. 283-286, by. Dr. F. Hirth, Shanghai.)

The third or "Fulin-Rome-theory" was launched by Dr. K. Shiratori, of the Tokyo Imperial University, who says: "Fulin is Rome. The word Rome was corrupted into Urum by the Huns and Tartars, and then Urum or Wrum was corrupted again into Butrum and, finally, this Butrum was corrupted into Butlin. So Fulin comes from Butlin, which is from Butrum, which is again from Wrum of the Turkish races for Rome. The people of the Ural-altaic Familyespecially Turks, Mongols, Manchurians, Koreans and Japanese, are apt to help themselves in pronouncing any word beginning with an ' $R$ ' sound-Rome, for instance, becoming 'Urom.' The Chinese obtained the sounds of Wrum from some of the Ural-altaic races, and they applied the two Chinese characters 'Fu-lin' for them." ("On the 
Question of Ta-ts'in and Fu-lin," by Dr. Shiratori in The Historical Magazine, Vol. XV., 54.)

These theories show that the Fu-lin question is still an unsolved mystery as it was fifty years or more ago. It was a mystery in 1860 , when Mr. Phillips expressed his views about it saying: "Fu-lin is a mystery." No further progress in solving it has been made until now. In the enlightened twentieth century it is as dark as in the middle of the nineteenth.

But gazing at the stone, we notice some seventy-five names rendered in both Chinese and Syriac, and amongst them a priest's name written "FU-LIN" (拂林), and the Syriac given for that Chinese name is "Ephraim."

On looking still more closely we discover that there is one more name "Ephraim" for which the Chinese "Hsüantê" (主德), i.e. "Mystery-virtue," is given as an equivalent.

Judging from the parallel fact that the name "Enoch" was expressed in Chinese by Ling-shou (涟 善), which means "Spirit-life-eternal," and the name Constantine (居 信) by "Stay-in-Faith" in our Inscription, we may safely say that the name Hsüan-tê, "Mystery-virtue" for "Ephraim," must be the translated name, the word "Ephraim" being supposed to come from the Hebrew root "PHARAH," "fruitful." Thus, "(Be fruitful of) Mysteryvirtue," was the underlying idea in the priest's name as rendered in Chinese, whilst "Fu-lin" is simply the Chinese phonetization of the sound "Ephraim." This is quite plain from the Chinese characters for “E-fu-lin" (遏挮林) in Prof. Pelliot's Diptychs.

According to the Chinese History of the T'ang Era, the name "Fu-lin" appeared for the first time in the middle of the seventh century A.D. The Chronicles say:

"In 645 A.D., King Po-to-li of Fu-lin sent an embassy" (貞觀十九年拂林國王波多力遺使).

Now in our Inscription (which was undoubtedly written 
in the year 780 A.D.) we find the "Priest Fu-lin" represented by the same Chinese characters.

It is most natural for us, therefore, to conclude that if the Priest "Fu-lin" in the eighth-century Inscription is Priest "Ephraim," the country indicated by the word "Fu-lin" in the seventh-century writings should be interpreted as "the Country of Ephraim."

But how we can identify this "Kingdom of Ephraim," with Po-to-li (which is the Chinese corruption for "Patriarch") at the head of its government, with the so-called "Syria" is quite another matter.

The Chinese history says: "To the north-west, this country of Persia (波斯 國) borders on the Kingdom of Fu-lin (拂林國), which resembles the kingdom of Persia in point of soil, manners, and customs; but they differ in point of language and appearance of the inhabitants. These also possess a good quantity of valuable gems and are very rich.

"To the south-west of Fu-lin, in an island of the sea, is the kingdom of the western women; here there are women only, with no men; they possess a large quantity of gems and precious stones, which they exchange in Fu-lin. Therefore, the King of Fu-lin sends certain men to live with them for a time. If they should have male children, they are not allowed to bring them up."

This description of the Kingdom of Fu-lin is from the "Buddhist Records of the Western World," by Hsüantsang, the Chinese Pilgrim, who left Hsi-an-fu in 628 A.D. and returned to China in 645 A.D., having spent seventeen years in India and in travelling through the Central Asian kingdoms lying between China and India.

Evidently this Pilgrim-author did not visit Persia or Fu-lin personally, as he tells us in his introductory remarks that he himself visited I IO countries, but that those other 28 countries of which he wrote, he described from reports 

(漞 踐者一百一十國傅聞者二十有八).
(To our regret these important clauses have been generally omitted in the European translation of the book. Perhaps the translators could not obtain the best text for their translations.)

Thus none of the writings of contemporary authors affect what we have already said.

Again, among the fragments discovered by Prof. Pelliot there is a portion of a book called "Hui-ch'ao's Visit to the Five Indies” (盖超往五天䇥國傳), in which the following paragraphs are quite distinct and legible:

“From Takharestan (吐火羅國) going westward for one month, we arrived at Persia. This Kingdom of Persia formerly ruled over Tadjik (大筫). The Tadjik used to be the pastoral people under the Persian king, but afterwards they rebelled against the king, and not only gained their independence, but finally power to rule over Persia... . Tadjik trade in the Western Sea and their ships sailing southward reached the island of Ceylon. . . . Again, going from Persia northward for ten days across the mountains, we reach Tadjik, and beyond it there is Little Fu-lin (小拂踟國).

" They worship God, but do not know Buddhism. In their Law they do not practise kneeling down.

- "Again, Greater Fu-lin lies to the north-west of the sea which bounds Little Fu-lin. The king of Greater Fu-lin has a strong army and is not subject to any other country. The Tadjik invaded it without success. The land is wide enough and full of precious things-mules, donkeys, sheep, and horses, and mats, etc. Their dress resembles that of Persia and Tadjik (大突), but their language is not the same."

The "Land of Ephraim"-what is it? and where was it ? These questions must be settled by specialists, but one thing is clear, through the light shed by the Priest Ephraim's name on the stone, that the "Fu-lin Country" is "the Land of Ephraim," that is, the land from which the missionaries came. 
Thus the stone is proved from Chinese sources to be both When and historically and calligraphically genuine. We how was the shall now proceed to consider when and how it Stone burled? came to be buried. Even the supposed causeswhich are probable enough-may still serve as indirect proofs of the genuineness of the stone.

Now the Nestorian Monument, as we know for certain, was erected on the $4^{\text {th }}$ of February, 78I A.D. ; and after having lain buried in the ground for many centuries, was discovered in 1623 A.D., or, more strictly speaking, not later than 1625 A.D.

We can only ascertain the time of its burial indirectly, for prior to 1623 , or 1625 A.D., nobody knew anything about it. The Inscription is not found in any of the "Stone and Metal Collections" of the Sung or Ming Dynasties; that is to say, in works compiled as far back as the year 1064 A.D., when books on "Stone and Metal Collections" were first compiled in China.

It is in Wang Ch'ang's (王誡) collection written in the seventeenth century that our Nestorian Inscription first appears. It is clear that none of the writers on "Stone and Metal Collections" between the tenth and the seventeenth centuries were acquainted with it. Only the Ta-ch'in monastery was referred to in the book called "Ch'ang-an Topography” (長安志) (20 Vols.), by Sung Min-ch'iu (朱敏求), in I079 A.D., who thus describes it:

"In the north-east of the I-ning Ward there was the Persian temple. In the twelfth year of Chêng-kuan (貞 䘽) $(638$ A.D.), the Emperor T'ai-tsung had it built for A-lo-ssŭ (阿羅 斯) (i.e. A-lo-pên, 阿羅 本), a foreign monk from $\mathrm{Ta}_{\mathrm{a}} \mathrm{Ch}$ 'in.

"To the east of Li-ch'iian Ward, the ancient Persian monastery stood. This was built there in the second year of the I-fêng (儀鳳) Period (677 A.D.), by the three brothers 
of Firus (卑路斯), who obtained leave from the Chinese Emperor to build it.

"During the Shên-lung (触龍) Period (705-707 A.D.) of the Emperor Chung-tsung, Tsung Ch'u-k'o (宗楚客), the favourite of the Emperor and once Prime-minister, occupied the Monastery building as his residence and removed the Monastery to the south-west corner of Pu-cheng Ward and to the west of the Zoroastrian temple."

Now, why did Sung Min-chiu, with all his learning, make such a foolish mistake as to write A-lo-ssŭ (阿 羅 斯)* for A-lo-pên (阿 羅 本) ? If he, or his assistant, could have got a rubbing of the Inscription or seen the stone itself, such a mistake could not have occurred. Why did he not see the rubbing in the early part of the eleventh century? Was it not mainly due to the fact that the stone was not then standing ?

We think the monument must have been removed long before Sung Min-ch'iu's time, or else so able a writer could not have made such a slip of the pen.

As there is no mention of the Inscription in the books upon "Metal and Stone" compiled between the tenth and seventeenth centuries, we may justly conclude that the monument must have been buried some time prior to the eleventh century, and we must therefore try to ascertain the most probable date for its burial between those years, 781 A.D. and 1064 A.D., when the first compilation of "Metal and Stone Collections" was made.

During these 283 years there were at least two occasions on which the Nestorian Stone might have possibly been buried. One is what may correctly be called "the Ta-ch'in Rebellion" of 783-784 A.D. The other is the well-known great religious persecution by the Emperor Wu-Tsung of Buddhism and other foreign religions-Nestorian, Mohammedan, and Zoroastrian-in 845 A.D.

* 長安志 preserved in the Ueno Library, Tokyo, has 新 instead of 
The general opinion amongst writers on the Nestorian Inscription is that the stone was buried by some Nestorians to save it from the general destruction that followed the persecution of 845 A.D.

But a new theory put forth by us recently that the stone might have been buried on the return of the Emperor Te-Tsung from Fêng-t'ien to Ch'ang-an in 784 A.D., when the Ta-ch'in Rebellion came to an end with the death of Chu Tz'ú (朱 泚), the ringleader, and with the execution of all his party, is not altogether groundless.

We shall first speak of the Ta-ch'in Rebellion and then of Wu-Tsung's persecution.

Why do we call this rebellion of Chu Tz'ú in 783 A.D. "the Ta-ch'in Rebellion"? It is because he called himself "the Emperor of Ta-ch'in."

He used exactly the same name and ideographs as are used in the Nestorian Inscription of 781 A.D. The rebellion, as recorded in the authentic history of China, broke out in October, 783 A.D., but no historians, native or foreign, give the real causes of this rebellion. Out of the dry official documents of that time we can only make out how it was started.

When Yao Ling-yen (蚖 命 言), the Governor-general of Ching-yuian (涇 原), arrived in the Imperial City on his way to Chiang-chou (稌 州) at the head of 5000 soldiers at the end of October, 783 A.D., it was winter and very cold. The soldiers expected some extra bounty and liberal gifts from the Emperor's own hand, as they had fought so long and so well for him in the frontier service. But, to their great disappointment, nothing was given to them in the way of recognition for their services, and no words of consolation even for the toils of the campaign were expressed.

Two days afterwards, when they were about to leave the capital and some companies had already marched a few miles away from Ch'ang-an, the Mayor whose name was Wang Hung 
(王炀) wanted to give them consolation, and invited them to a dinner. But all he could give was poor, hard rice and scanty vegetables.

When they saw the poor fare before them, they became so much enraged that they kicked the tables to pieces and broke all the dishes and cried, "To the Imperial Palace!" "To the Palace!" "Let us help ourselves to the treasures kept in the Imperial Warehouse!"

All at once rushed towards the Imperial Palace. The Emperor and all his court, taken by surprise, knew no other course than to take to flight. So they all ran away from the postern gate towards Fêng-t'ien (奉天), i.e. Ch'ien-chou (乾州), about 30 miles north of Ch'ang-an.

The mutinous soldiers then occupied the Palace and the. Imperial Capital. They decided to have General Chu Tz'ŭ (朱泚), who happened to be in the Capital at that very time, as their new Emperor, and they conducted him accordingly to the deserted Imperial Palace.

Chu $T z ' \breve{u}$, apparently most unwillingly, accepted their proposal and called himself "Ta-ch'in Emperor!"

$\mathrm{He}$ then proceeded to organize his own Government. In doing so, he relied chiefly on the support of Yüan Hsiu (源 休), who was famous for tact; Chang Kuang-chêng (張光宠), who was a man of Chou-chih and had a reputation for sincerity and faithfulness; Chiang Chên (蔣 鍄), who was noted for his honesty and integrity; and P'êng Yen (彭偃), who was well known for his learning; and Ching Kang (敬 釭), who was famous for his bravery and sagacity. He afterwards added Ch'iao Lin (喬琳), the Imperial tutor, to his Government.

It was at Chou-chih that this Ch'iao Lin deserted the cause of the Emperor Tê-Tsung on the Emperor's way to Fêng-t'ien in 783 A.D. He was one of the court party who followed the Emperor, but only as far as the neighbourhood of Chouchih, where he hid himself in the Hsien-yu-ssŭ (仙遊寺)- 
"Saint-visited Monastery"-and declined to proceed any farther on the pretence that his health did not permit him to do so; the next day, however, he joined the Ta-ch'in Rebels.

But at last the Ta-ch'in rebels were defeated, and the men who supported the cause of $\mathrm{Chu} \mathrm{Tz}_{\mathrm{z}} \mathrm{u}$ were beheaded at Fan Hsien, thirty miles north-west of Chou-chih, in 784 A.D., and then the Emperor Tê-Tsung returned to Ch'ang-an through Chou-chih, and probably passed by the Hsien-yu-ssŭ, "Saint-visited Monastery!"

If this "Saint-visited Monastery" had been a Nestorian one, and the very spot where the Nestorian Stone had been erected in 78I A.D., the stone might have been ordered to be buried because it had upon it the very hateful name of Ta-ch'in.

If it were not buried by the Emperor's order, then some, we suppose, of the Nestorians, anticipating its destruction by the Imperial order, might have buried it in order to save it from the hand of destroyers.

This supposition of ours is greatly strengthened by the fact that the stone was actually dug out at a place between Chou-chih and Hsi-an-fu, and by the fact that none of the Chêng-yuian (貞 元) and Yüan-ho (元 和) writers-785 A.D.820 A.D.-Han Yü, Liu Tsung-yuian and others, make the slightest mention of the stone in their writings. Han $Y \ddot{u}$ came to Ch'ang-an in 786 A.D. for the first time when he was nineteen years old, whilst Liu Tsung-yuian came to the capital in 788 A.D. Not the least trace of the stone can be seen reflected in the prose or poetry of the age. This mystery can only be accounted for if the stone was buried in 784 A.D.

If this supposition fails to explain when and why it was buried, then we must seek the time and the circumstances of its burial in 845 A.D.

Already the reaction against the Nestorians and the Buddhists began to appear as early as 797 A.D., when for the 
first time the Confucianists were allowed to join the Imperial Birthday Service. Previous to that time the privilege was given only to the Buddhists, Taoists, and Nestorians.

Again, in 819 A.D., Han Yü (韓 流), “the Macaulay of China," addressed a memorial to the Emperor Hsien-Tsung against the Emperor's order to bring a famous bone-relic of Buddha to the capital and to deposit it within the precincts of the Imperial Palace. Han Yü said that the relic should be delivered to the proper officials to be thrown into the water, or into the fire, to be made an end of for ever. He concluded his famous memorial thus :

"If the bone of Buddha has the efficacy of the living Spirit to bring calamity or trouble as punishment, let it alight upon my own person! High Heaven sees everything, and I have nothing to fear!"

Although Han $Y \ddot{u}$ was punished for his bold action, public sympathy was with him; and Taoists and Confucianists, taking advantage of this opportunity, stirred up a reactionary movement against the foreign religions, which resulted in the great persecution inaugurated by the Imperial Edict of Wu-Tsung, A.D. 845-the third great persecution that occurred during the whole eight hundred years since Mahayana Buddhism first entered China in Ming-Ti's (漢明常) reign, A.D. 67-during which time it established itself as "Chinese Buddhism."

Prior to the proclamation of Wu-Tsung's Edict (according to the Chinese contemporary history), there were over 44,600 Buddhist monasteries with 265,000 monks and nuns.

This is not an excessive number when compared with the 71,819 Buddhist temples with 123,448 priests we have now in Japan, besides 51,284 shrines with 74,559 Shinto priests.

The Edict was entitled "The Proclamation ordering the destruction of the Buddhist monasteries." It runs thus :

"We learn that there was no such thing as Buddhism 
prior to the Three Dynasties, i.e. Hsia (夏), Yin (殷), Chou (周).

"After the dynasties of Han and Wei, the Image-Teaching. gradually began to flourish. And once established, in that degenerate age, this strange custom prevailed far and wide, and now the people are soaked to the bone with it. Just now the national spirit begins to be spoiled unconsciously by it ; and, leading the heart of the people astray, it has put the public in worse condition than ever. In the countrythroughout the Nine Provinces, and among the mountains and fields as well as in both the capitals-the number of priests is daily increasing and the Buddhist temples are constantly winning support.

"Wasting human labour in building; plundering the people's purse by golden decorations; ignoring parents and the Sovereign in contributions; neglecting both husband and wife by their vigil-keeping; no teaching is more harmful than this Buddhism. In breaking the laws of the country and injuring the people, none can surpass this Buddhism.

"Moreover, if a farmer neglect his field, many suffer the pangs of starvation from his negligence; if a woman neglects her silk-worm culture, many suffer the calamity of being frozen to death through her negligence. Now there are at present so many monks and nuns that to count them is almost impossible. They all depend on farming for their food, and upon silk-worms for their clothing !

"The public monasteries and temples, as well as private chapels and shrines, are innumerable; and all of them so gigantic and imposing that they vie with the Imperial Palace in splendour! In Dynasties Chin (晉), 265 A.D.-420 A.D., Sung (株), 420-476 A.D.,Ch3 (唯), 479-501 A.D., and Liang (梁), 502-556 A.D., the resources of this Empire were exhausted and the country gradually declined, whilst its manners and customs became flippant and insincere, solely because of this Buddhism. 
"Our Imperial ancestor $T$ 'ai-tsung put an end to confusion and disorder by his arms, and built up the glorious Middle Kingdom and governed his people by his accomplished learning and culture. The right of 'the pen' (i.e. peaceful rule or civic administration), and 'the sword' (i.e. war) belongs to the State, and they are the two weapons wherewith to govern the Empire. How dare the insignificant Teaching of the Western Lands compete with ours? During the periods of Chêng-kuan (貞 觀) (627-649 A.D.) and K'aiyuian (開 元) (7I3-755 A.D.), things were bettered once for all, but the remnants were smouldering, and poverty began to grow bigger and wider and threatened to set the country ablaze!

"After closely examining the examples set by our Imperial predecessors, We have finally decided to put an end to such conspicuous evils. Do ye, Our subjects, at home and abroad, obey and conform to Our sincere will. If ye send in a Memorial suggesting how to exterminate these evils which have beset Us for many Dynasties, We shall do all We can to carry out the plan. Know ye that We yield to none in fulfilling the laws of Our predecessors and in trying to be helpful to Our people and beneficial to the public.

"Those 4600 monasteries supported by Government shall be confiscated and, at the same time, 260,500 nuns and priests shall return to secular life so that they may be able to pay the taxes. We shall also confiscate 40,000 private temples and monasteries known by the name of Aranya, together with the fertile and good lands amounting to several tens of millions of acres; and emancipate 150,000 slaves and make them into free, tax-paying people.

"Examining into the teachings from the foreign lands in the Empire, We have discovered that there are over 3000 monks from Ta-ch'in and Mu-hu-fu; and these monks also shall return to lay life. They shall not mingle and interfere with the manners and customs of the Middle Kingdom. 
"More than a hundred thousand idle, lazy people and busybodies have been driven away, and numberless beautifully decorated useless temples have been completely swept away. Hereafter, purity of life shall rule Our people and simple and non-assertive rules prevail, and the people of all quarters shall bask in the sunshine of Our Imperial Influence. But this is only the beginning of the reforms. Let time be given for all, and let Our will be made known to every one of Our subjects lest the people misunderstand Our wish."

This terrible blow to Chinese Buddhism is known as " the Third Persecution," and was the greatest that Buddhism encountered since its introduction into China in 67 A.D. Of all the foor persecutions, this, resulting from Wu-Tsung's Edict, was the worst.

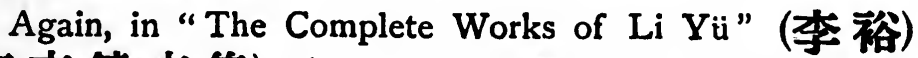
(李交餴交集), who was Prime Minister to the Emperor Wu-Tsung in that very year 845 A.D., we read his official letter addressed to the Emperor congratulating the Emperor on his successful destruction of the temples and monasteries (see Appendix, No. VIII.). In this letter $\mathrm{Li}$ Yï refers to the $2000^{*}$ Nestorians and Mohammedans as we have already seen in the Imperial Edict above referred to, which was in reality written by $\mathrm{Li}$ Yü himself, for it was the official duty of a Prime Minister to write the draught of an Imperial decree for the Emperor, whilst the style and phraseology of the letter and Edict are exactly the same (see Appendix, No. VIII.).

These and many other writings of the time show how badly the Nestorians suffered from the cruel hand of the Persecutor. It is not at all surprising that all the writers on the Nestorian Stone agree in saying that it was most likely due to this terrible persecution that the Assyrian Monument

- Instead of 3000 as mentioned above, 2000 is according to the oldest copy preserved in the Ueno Library. 
was buried by Christians who wished to preserve the stone from the general destruction ordered by the Emperor Wu-Tsung.

Although we learn from foreign sources that there were several Nestorian churches in China in the eleventh and fifteenth centuries," we never read in Chinese books anything about the Assyrian Church and its members after this disaster of 845 A.D. Even when Wu-Tsung's successor reversed his anti-Buddhist policy and began to restore the monasteries during several years, there arose no emperor who remernbered either A-lo-pên and his monks or their successors who erected the stone.

- See Gibbon's words quoted on p. 38. Besides we read the following words of Sir Henry Yule: "No more is known, so far as I am aware, of Christianity in China till the influx of European travellers in the days of Mongol supremacy. We then again find a considerable number of Nestorian Christians in the country. It is probable that a new wave of conversion had entered during the twelfth and thirteenth centuries, consequent on the Christian. ization of large numbers among the Turkish and Mongolian tribes, of which we have many indications, and on the influence exercised by those tribes upon Northern China, both in the time of Chinghiz and his successors, and in the revolutions which preceded the rise of that dynasty."

Again we read: "In the time of Marco Polo we find Nestorian Christians numerous not only at Samarkand but at Yarkand, whilst there are such also in Chichintalas (identified by Pauthier with the modern Urumtsi, north of the Thian Shan), in Suchau and Kanchu, and over all the kingdom of Tangut, in Tenduc and the cities east of it, as well as in Manchuria and the countries bordering on Corea. Polo's contemporary Hayton also testifies to the number of great and noble Tartars in the Uigur country who held firm to the faith of Christ. As regards the spread of Nestorian Christianity in China Proper at this period we do not find in Polo so many definite statements, though various general allusions which he makes to Christians in the country testify to their existence. He also speaks of them specifically in the remote province of Yunnan, and at. Chinkiang-fu, where they had two churches built in the traveller's own day by Mar Sergius, a Christian officer who was governor there. Their number and influence in China at the end of the thirteenth century may also be gathered from the letter of John of Monte Corvino (pp. 198 seg.) in this volume; and in the first part of the following century from the report of the Archbishop of Soltania, who describes them as more than thirty thousand in number, and passing rich people. Probably there was a considerable increase in their numbers about this time, for Odoric, about 1324, found three Nestorian churches in the city of Yangchau, where Marco would probably have mentioned them had they existed in his time." (XCVII.-XCIX., Vol. I., "Cathay and the IVay Thither.") 
This is not surprising, for Persia (the centre and inspirer of the Christian Church in the Orient) lost political influence after the Mohammedans came into power in Central Asia and China in the eighth century, and the Christians began to be absorbed into the larger body of Mohammedans.

This, at first sight, seems incredible. But turning to the history of the Jacobite schism or Monophysite heresy concerning the one nature of Christ in the sixth century, we shall find that "the opponents of the Council of Chalcedon formed themselves into dissenting bodies absolutely separated from the Orthodox churches and provided with a complete hierarchy from the Patriarch of Antioch down to the inferior orders, and that these communities maintained their position in spite of the official Imperial churches, and especially after the Moslem invasion, attained a high degree of prosperity." (Duchesne's "Origines du culte Chrétien," p. 65.)

Of course, 3000 Nestorian and Mohammedan monks are too insignificant a number to compare with the 260,500 monks and nuns of Buddhism.

But had they been strengthened by the State from the ninth to the thirteenth centuries, and had they not been cut off from the main body of the Church the numbers might have greatly increased and some portion of the $21,500,000$ of Mohammedans and the ten millions of the Chin-tan Chiao (金丹戫) now in China might have been Christian.

If our first supposition be accepted, the result would be that the stone stood above ground only a few years and that neither Han Yü and Liu Tsung-yüan of China nor Kobo Daishi of Japan could have seen it. But if the second supposition about the date and the reason for burying the stone be correct, then this Monument stood conspicuously above ground for only sixty-four years, viz. from A.D. 781 to 845 , steadily witnessing to the Truth of God in the heart of China. Then, having given its witness-" the Teaching Stone". is its name 
in the Inscription-it was buried in the earth, and there preserved unhurt for some 780 years.

Whichever view we may take, the student-priest Gyoga (行 賀) who returned from Hsi-an-fu in A.D. 784 must have been the first from Japan who ever saw the Nestorian Stone, and if we accept the second supposition, the Tendai-shu priest Jigaku (掏留) who returned from China in A.D. 84I must have been the last Japanese who saw it. In other words, according to the second theory, the stone existed twenty-two years before and forty-four years after our Kobo-daishi visited Hsi-an-fu in 804 A.D., and studied Sanscrit from Prajña, the Kashmir monk, who had co-operated with Ching-ching (Kingtsing), Adam, the author of our Inscription, in translating a Buddhist sutra.

The genuineness of the Monument itself is one thing Nature of the whilst the accuracy of the Inscription is another. Ch'ang-an
civllization: One cannot by any means say that all the stateChristian elements in it -Christian Japan. ments in this Inscription are correct simply because the stone itself is genuine.

crepancy, self-contradictions, and ambiguity of the expressions used in the Inscription, whilst yet much remains to be done in the way of textual criticism.

This is not surprising. Things written in the eighth century with but dim knowledge of Heaven and Earth must be tested by those whose knowledge has been enlightened by scientific study and their minds widened by travel and international communication.

But one thing is sure, namely, that, by studying the Inscription, we are more and more convinced of its genuineness, although at the same time we can understand the ignorance of the Nestorian pioneers of Christianity in the Far East.

Their relations with Buddhism, Taoism, and Confucianism were quite different from those that Christian missionaries now enjoy in China and in the Far East generally. 
At present Christian missionaries are more advanced in science, if not in philosophy, than the Chinese amongst whom they work. It was not so in the seventh, eighth, and ninth centuries.

If we trust what is written in the Inscription, at least if we assume that Christianity may have been well known at Ch'ang-an during two out of the three centuries of the $T$ 'ang Dynasty, we cannot but recognize the fact that we Japanese were, consciously or unconsciously, and directly or indirectly, much influenced by the Nestorians. Some of the thoughts that our ancestors derived from China during the seventh, eighth, and ninth centuries were Christian thoughts in Chinese garb, like these words that we once thought were pure and simple Chinese, but which are now proved by scholars to be nothing else but Greek or Hebrew.

If we were to follow the example set by the late Prof. Max Müller, who was wont to distinguish between the Christianity of the Church and that of Christ, China and the Chinese of the T'ang Era were far more influenced by the Christianity of Christ than some parts of European Christendom are to-day. For instance, Russia is, no doubt, a Christian country, but Christianity-if not Ecclesiasticismexercised much greater influence in China during the $T$ 'ang Dynasty than in the Russia of the Empress Katherine the Great.

Those who labour as missionaries in the Far East should remember that they are working in a field that has been already, thinly as it may be, sown with the seed of Gospel Truth. They must realize that they are treading on "holy ground"!

The people to whom they preach to-day are the spiritual descendants not only of Confucius or of Sakyamuni, but of the Early Christians themselves, and in rooting up what appears to them to be "tares" they should beware lest they are also destroying the "wheat" which has lain: 
buried for centuries-unrecognized for lack of discerning eyes!

The Nestorian Monument itself is a great witness to this fact.

We are convinced that the China of the T'ang Era was under Christian influence actually, if not in name.

Christian humanity was then well developed, and in the Chinese literature of that period we find an account of the Emancipation of slaves by Liu Tsung-yuian (柳宗 元) in his province, whilst the ideas of individuality and human equality were also highly developed in Chinese society.

For we read in this Inscription: "The great Emperor Kao-Tsung (A.D. 650-683) most respectfully succeeded to his ancestors; and giving The True Religion (i.e. the Luminous Religion) the proper elegance and finish, he caused the monasteries of the Luminous Religion to be founded in every department. Accordingly he honoured A-lo-pên by conferring on him the office of the Great Patron and Spiritual Lord of the Empire. The Law (of the Luminous Religion) spread throughout the Ten Provinces (of China), and the Empire enjoyed great peace and concord. Monasteries were built in many cities, whilst every household was filled with the great blessings (of Salvation)."

And that this is no exaggeration is proved by the fact that when this Inscription was written "the titular Directorship of the Imperial Bureau of Ceremonies, Music, Festivals, Sacrifices, and Worship," was held by a Nestorian Priest and Archdeacon, the head of the Church of Kumdan and Saragh, whose name was Gabriel (業利).

Therefore, unless we can prove this Inscription to be entirely false-which is impossible-we may accept what is written therein with a faith supported by historical evidences.

If we have to call the Ch'ang-an civilization "a kind of Christian civilization," then we must necessarily admit that 
those countries that received the Ch'ang-an civilization in the Middle Ages were morally as good as any European countries which profess the Roman Catholic or the Greek Orthodox Faith in Christendom, because this Chinese Christendom was a daughter of the Assyrian Church which claimed descent from the Apostle Thomas and his immediate disciples.

Of this effect we shall let the student judge for himself

What was the effect on China of the Discovery of the Stone in A.D. 1623 ? when he has read the actual words of Abbé Huc, the author of "Christianity in China, Tartary, and Tibet." This missionary wrote :-

"One does not know how to count the large number of people who came from all parts to view this stone, some admiring it for its antiquity, and others for the novelty of its characters which seemed to them to be foreign.

"And as the Light of the Gospel and the knowledge of Our Religion is now spread in all parts of the Empire, a pagan * who is a very intimate friend of Dr. Leon $\mathrm{Li}$ (a Christian mandarin), having heard of the Mysteries hidden under this writing, thought to oblige his friend by sending him a copy although they were separated by a month and a half's journey-the Christian mandarin living in the city of Hantcheou-fu (杭 州 府), where our Fathers were quasi-refugees because of the last persecutions.

"Three years later, in 1628 A.D., Semedo and other Fathers passed through the province with a Christian mandarin, named Philip, who desired to have them in his company during a mission to this country.

"They were not there long before they built a church and a residence at Hsian-fu, capital of the province; because God who had brought to light so rich a testimony of the

* This must be Chang Kêng-yï who first sent a rubbing to Dr. Leon Li in 1625. But Leon $\mathrm{Li}$ writes on the 12th of June, 1625: "Chang Kêng-yü of Ch'i-yang, the co-sufferer in the cause." This indicates that he was a Christian, 100. 
possession which the preachers of His Law had once taken in His Name of so flourishing an empire, would once again use it for the confirmation of $\mathrm{His}$ subjects and re-enter more easily into His ancient rights."

The Abbe Huc continues:

"The discovery of the Monument of Hsi-an-fu made a great noise in all the Provinces of the Empire, and contributed not a little to the success of the missionaries.

"The Christians, who had been forced to submit to such outrages and humiliations in the last persecutions, enjoyed the consideration of both mandarins and people, above all since that most illustrious of neophytes, Doctor Paul (徐光啓), had been raised to the rank of Prime Minister. This was to Chinese eyes a powerful argument to see at the head of the Government a worshipper of the Lord of Heaven.

"At this epoch, conversions were numerous ; many missionaries reaped the labours of the ancient Apostles; they founded new churches, and notwithstanding the troubles which agitated the Empire the Christianity of China made marvellous strides. In 1627 A.D., 13,000 Christians were reckoned in seven different Provinces, viz. Kiang-si, Chekiang, Shan-tung, Shan-si, and Pechili.

"This number grew so rapidly that ten years later it had risen to over 40,000 . This figure is no doubt insignificant compared to the immense population of China ; but if one considers that these results were obtained in less than forty years, after the incredible difficulties to establish Christianity in the Interior, in the midst of all kinds of contradictions and of bloody persecutions; if one considers, besides, that they had to evangelize the most anti-religious people in the world, one is forced to concede that the missionaries' successes were considerable, and that it is possible by force of zeal and perseverance, to fertilize the most barren soil.

"Besides Paul, the Prime Minister (who succeeded the terrible persecutor of the Christians), and $\mathrm{Dr}$. Leon $\mathrm{Li}$ and 
Dr. Michel, ${ }^{*}$ the distinguished Doctors of Literature-who were mandarins as well as pillars of the Church in Chinathere were 14 mandarins of the First Button, 1o Doctors of Literature, II Licentiates and 300 Bachelors, Christianity counted also many proselytes in the Imperial Familythe missionaries baptized over 140 ; although these minor Princes held no official position in the Government, still, by reason of their birth and dignity, they had a certain influence in State affairs.

"Forty of the principal eunuchs attached to the Emperor's service were also converted to the Faith, and thirty-eight of the Court ladies in the Imperial Harem were baptized by the eunuchs, to whom special authority had been given on account of the strict seclusion in which these ladies were kept. The story of their faith and devotion although excluded from Christian worship, is very touching. The Chinese neophytes, whether mandarins, literati, princes, or people, were sincerely attached to the Religion, and fulfilled its duties faithfully." (See Huc's "Le Christianisme en Chine," Vol. II., p. 3 I9.)

The history of the Nestorian controversy which produced The origin such far-reaching results must be interesting and develop- to every student of theology. But as from the Nestorian or nature of our work we cannot devote much space (to speak more correctly) the Assyrian Church. to it, we shall only refer to Nestorius and his doctrines as a side-light to prove that our Monument belongs to "the Assyrian Church of the Messiah"- that is to say, Christ.

Nestorius, Bishop of Antioch, succeeded Sisinnius as Patriarch of Constantinople in A.D. 428. Brought up in

* The wonderful story of Dr. Léon and his healing through the waters of baptism and the holy anointing, wherein his body recovered strength and his soul received a supernatural power conforming itself unrestrainedly to the Law of God, is well worth reading in this book. Whilst a pagan, with his good works and honesty of heart in the Search for Truth he drew towards him those special gifts from God which germinate the Faith in such souls. The lives of utter devotion led by these mandarins Leon and Michael, and of the Prime Minister Paul, are deserving of our profoundest study. 
the cloister, he had imbibed its tendencies to narrowness, partisanship, impatience, and ignorance of mankind which are not infrequently found among those who have been educated apart from their fellows.

According to Neander, Nestorius was from Antioch and was very eloquent and without guile. Through his austere life, he had won the admiration of many. His personality may be realized from the words of his address to the Emperor Theodosius II, immediately after his appointment to the Patriarchate.

"Give me, $O$ Prince, a country purged of heretics and I will give you heaven as a recompense. Assist me in destroying heretics and I will assist you in vanquishing the Persians."

According to the contemporary historical writer, Socrates, before he had "tested the waters of the city" (i.e. before he knew its condition) he flung himself headlong into acts of violence and persecution. Five days after his consecration he resolved to destroy the oratory in which the Arians celebrated their worship. He did it so thoroughly that he drove them to desperation and lost the sympathy of the thoughtful in his own communion.

"Roughly speaking, there were two tendencies in the Theology of the time which developed differently-the one in Syria and the other in Egypt. The former favoured the critical interpretation of Scripture and the application of the logical investigation to the facts and doctrines of Christianity, while the latter laid stress on the Divine, i.e. its mysterious or mystical side.

"Every day these two tendencies approached nearer to a collision which was destined to become fiercer as the personal jealousies and animosities grew stronger and keener, when Constantinople was elevated to the second place among all the Patriarchates as the New Rome. Early in the fifth century there was nothing to hinder, but everything tended rather to hasten, the outbreak of hostility. 
"Already the seeds of a breach had been sown between Alexandria and Constantinople in the time of Theophilus, Patriarch of Alexandria, and John Chrysostom, Patriarch of Constantinople, when Theophilus succeeded in the end of the fourth and at-the beginning of the fifth century $(381-403$ A.D.); but it was the activity and violence of Nestorius and his supporters that set the smouldering fire ablaze!

"Even in Antioch there were two precisely opposite tendencies: one called Apollinarianism, which sacrificed to the unity of the person the integrity of the natures, at least of the human nature, and which anticipated the Monophysite heresy, whilst the other was Nestorianism, which held the Divine and human in Christ so rigidly apart as to make Him virtually a double person, as taught by Diodorus, Bishop of Tarsus (394 A.D.), and Theodore, Bishop of Mopsuestia (393-428 A.D.).

"From this school proceeded Nestorius, who is said to be one of the strongest Christological heretics. How far he was heretical we need not trouble ourselves here. But if his doctrine differed from that of Theodore of Mopsuestia at all, it was because it was less speculative and more practical, and still less solicitous for the unity of the person of Christ.

"Already the very bold and equivocal expression ( $\theta$ Eótoкos) THEOTOKOS, 'the Mother of God,' had been applied to the Virgin Mary by Origen, Alexander of Alexandria, Athanasius, Basil, and others; and after the Arian controversy and with the growth of the worship of Mary, this expression passed into the devotional shibboleth of the time.

"It goes without saying that the expression THEO. TOKOS did not mean that the creature bore the Creator, nor did it mean that the Eternal God-head took its beginning from Mary. It was only inte.uded to denote the indissoluble union of the Divine and human natures of Christ, and the veritable incarnation of the Logos, who, taking human nature from Mary's body, came forth the God-man from her womb, 
and as God-man suffered on the Cross" (Dr. Schaff's "History of the Christian Churches," p. 717). For Christ was' born as a person, and suffered as a person; and the personality in Christ resided in His divinity, not in His humanity.

The Antiochian theology, however, could not conceive of human nature without a human personality, which it strictly separated from the Divine Logos.

"Already the expression, 'the Mother of God' had been disputed by Theodore of Mopsuestia. 'Mary,' said he, 'bore Jesus, not the Logos, for this Logos was and continues to be omnipresent, although it dwelt in Jesus in a special manner from the beginning. Therefore, Mary is strictly the mother of the Christ, not the mother of God. Only in a figure of speech can she be called also the mother of God, because God was in a peculiar sense in Christ. Properly speaking, she gave birth to a man-child in whom the union with the Lagos had begun, but still so incomplete that he could not yet (till after his Baptism) be called the Son of God.'

"Again Theodore said: 'Not God, but the temple in which God dwelt, was born of Mary.'

"When Nestorius became Patriarch in 428 A.D., he found two parties already existing in Constantinople : one of which was calling Mary 'Mother of God,' the other, 'the Mother of Man.'

"Nestorius himself took a middle course and proposed the intermediate expression, as a compromise, ' Mother of Christ,' -in Syriac, Mother of Messiah-because Christ was at the same time God and Man.

"He said in his first sermon concerning this particular point: 'You ask whether Mary may be called "Mother of God"? Has God then a mother? If so, heathenism itself is excusable in assigning mothers to its gods : but then Paul is a liar, for he said of the deity of Christ that it was without father, without mother, and without descent. No, my dear sirs, Mary did not bear God; the creature bore not the 
uncreated Creator,-but the man who is the instrument of the God-head; the Holy Ghost conceived not the Logos, but formed for him, out of the Virgin, a temple which he might inhabit (John ii. 2I). The Incarnate God did not die, but quickened $\mathrm{Him}$ in whom $\mathrm{He}$ was made flesh. The garment, which $\mathrm{He}$ used, I honour on account of the God which was covered therein and inseparable therefrom; $I$ separate the Natures but I unite the worship.'

"Consider what this must mean. He who formed in the womb of Mary, was not himself God, but God assumed him (assumsit, i.e. clothed Himself with Humanity), and on account of Him who assumed, he who was assumed is also called God " (Dr. Schaff's " History of the Christian Church," p. 718).

From these words of Nestorius arose one of the most farreaching controversies in the history of the Christian Church ; and the Antiochian .Christology, represented by Nestorius, began to provoke the bitterest opposition of those, more especially the monks, who were in sympathy with the Alexandrian theology. They contradicted Nestorius from the pulpit and insulted him in the street; whilst he did all he could to punish the monks who opposed him, and succeeded in condemning the view of his antagonists at a local Council held in 429 A.D.

The first voice against him was raised at his own capital by Proclus, Bishop of Cyzicus, the leader of his antagonists. Proclus was said to have been an unsuccessful rival of Nestorius for the Patriarchate. But of this we are not sure. At any rate, he carried the worship of Mary to an excess. He is said to have preached the following in honour of the Virgin Mary :

"The spotless treasure-house of virginity; the spiritual paradise of the second Adam; the workshop, in which the two natures were annealed together; the bridal chamber in which the Word wedded the flesh; the living bush of 
nature, which was unharmed by the fire of the Divine Birth; the light-cloud which bore Him who sat between the Cherubim; the stainless fleece in the dews of Heaven, with which the shepherd clothed his sheep; the handmaid and the mother, the Virgin and Heaven."

Cyril, the Patriarch of Alexandria, did not lose this chance of overthrowing his rival, the Patriarch of Constantinople, as his uncle and predecessor Theophilus had cunningly overthrown the noble Chrysostom in 403 A.D. The theological controversy was, therefore, a contest of the two Patriarchates and the two capital cities for ascendancy in the Christian world!

Cyril used every means to defeat his rival and succeeded. He wrote first to Nestorius; then to the Emperor Theodosius and the Empress Eudokia, as well as to the Emperor's sister, and finally appealed to Pope Celestine, who had condemned the Nestorian doctrine at a Council held at Rome in 430 A.D. This was due partly to Celestine's orthodox instincts, and partly to his anger with Nestorius for his action against the exiled Pelagians.

The controversy became so general and so critical that a great Council was summoned by Theodosius II. and Valentinius on the Day of Pentecost, A.D. 43I, to meet at Ephesus. This is known in history as "the Council of Ephesus."

Nestorius came first to Ephesus accompanied by sixteen bishops and an armed escort. He had the Imperial influence on his side, no doubt, but the majority of the bishops were against him, as the result of the Council shows. The prevailing voice of the citizens was decidedly against him, since Ephesus itself was the city where the worship of the Virgin Mary had replaced the age-long worship of the Light and Life dispensing Virgin, "Diana of the Ephesians" (Acts xix. 34), and the expression "Mother of God" was already firmly rooted there. 
Cyril appeared with fifty Egyptian bishops, besides monks and slaves, under the banners of St. Mark and the Holy Mother of God.

Archbishop Memnon of Ephesus with forty Asiatic chorepiscopi and twelve bisinops from Pamphylia were with Cyril.

The caravan of the Patriarch John of Antioch, who was a great friend of Nestorius, and who had tried to act as peacemaker between the two rivals, was detained on the long journey by floods, famine, and the riots resulting from these two causes.

Cyril refused to wait for these forty-two Syrian bishops, who supported Nestorius, and in the most treacherous way rushed matters through; and in consequence the decision of the Council was pronounced illegal by the Emperor.

The Council was opened in the Basilica of St. Mary with one hundred and sixty bishops-a number increased to one hundred and ninety-eight on the 22nd of June when the Council was actually opened. Sixteen days after Pentecost, Nestorius was cited to appear; but he refused to come until all the bishops should be assembled. The Council then proceeded without him and his friends, and finally condemned him as a heretic. The bishops unanimously cried: "We all anathematize Nestorius and his followers, and his ungodly faith and his ungodly doctrine, etc."

The following sentence of deposition was adopted at the close of the first session which lasted till late in the night : "The Lord Jesus Christ, who is blasphemed by Nestorius, determines through this Holy Council that Nestorius be excluded from the episcopal office, and from all sacerdotal fellowship."

The next morning the sentence of deposition was brought to Nestorius, but the Imperial Commissioner declared the decree to be invalid as it was passed by only a portion of the Council.

Four days after the Council, on the 26 th or $27^{\text {th }}$ of June, 
the Patriarch John of Antioch, and the forty=two Syrian bishops who sympathized with Nestorius reached Ephesus. The famous Theodore of Mopsuestia was a conspicuous figure among them. So Nestorius held a counter-council in his own dwelling under the protection of the Imperial Commissioner, and finally deposed Cyril of Alexandria and Memnon of Ephesus from all priestly functions as heretics and authors of the whole disorder, and declared the other bishops who voted with them to be excommunicated unless they should anathematize the heretical doctrines and proposition of Cyril.

Then followed all kinds of intrigues and Church politics quite unworthy of true Christianity. No sadder picture of uncharitable and unspiritual Christianity was ever seen. The most cruel heathen Councils could not hold a candle to this Church Council at Ephesus in A.D. 431.

After long delay, the Emperor, to whom both parties had appealed but who failed to understand the question at stake, finally resolved to confirm both the deposition of Nestorius and that of Cyril and Memnon, and sent John, one of his highest officers, to Ephesus to publish the Imperial sentence.

The deposed bishops were arrested. The Alexandrian party again appealed to the Emperor to release Cyril and Memnon. The Antiochians did the same and did everything possible to win the Emperor to their side. The Emperor was compelled to summon eight spokesmen from either party to his presence at Chalcedon to discuss the matter before him.

Meanwhile Cyril and Memnon were kept in prison at Ephesus, whilst Nestorius was allowed to retire to his former cloister at Antioch, and on the 25th of October, 431 A.D., Maximian was nominated as his successor in the Patriarchate in Constantinople. In October, 43I A.D., the Council of Ephesus was dissolved; Cyril and Memnon were 
set free and the bishops of both parties ordered to return to their respective sees.

Two years later a compromise was effected at the expense of poor Nestorius himself. That is to say, in 433 A.D., after much consideration on both sides and through the Imperial interference, union was effected on the express condition of his condemnation and deposition. The leaven of bribery used by Cyril and his party had done its work.

In A.D. 435 laws were enacted ordering that the Nestorians should be called "Simonians," instead of "Chaldeans "; that the writings of Nestorius should be burned, etc.

The unhappy Nestorius was dragged from his former "convent, the Cloister of Euprepius before the gates of Antioch." He went first to Arabia and then to Egypt, and is said to have lived until 439 A.D., but no one knows where and when he died.

The famous theological school of Edessa, which was the centre of the Antiochian theology and mission work and training ground of the Persian clergy, was finally dissolved by the Emperor Zeno in 489 A.D. But the rigorous measures of the Emperor against the Nestorians only proved in the Divine Providence to be the means of spreading Christianity to the Farthest East. The Theological School was removed to Nisibis on the River Tigris, where was the bridge by which the caravans crossed. By the end of that same fifth century, Nestorian teachers from Syria and Babylonia had crossed the border into Persia, where already pre-Nestorian Christianity was pretty strong.

The famous Bar Somas, bishop of Nisibis from 435 to 489 A.D., did much to spead Nestorian teaching in the East-in Central Asia, and then in China. He founded a new theological school at Nisibis and confirmed the Persian Christians in the Antiochian, i.e. Nestorian, theology against the Cyrilian Council at Ephesus. The Nestorians were 
greatly favoured by the Persian kings from Firuz (46I-480 A.D.) onward.

This might have been mainly due to the Persian antagonism to Rome and Persian political hatred of the Eastern Empire.

In 498 A.D. at the Council of Seleucia the Nestorians organized the Chaldean or Assyrian Church, and renounced all connection with the Church of the Roman Empire. In their liturgical language, they styled themselves Chaldean or Assyrian Christians-" "the Children of the East," but their opponents continued to call them "Nestorians."

They had their own Patriarch who dwelt in the double city of Seleucia-Ctesiphon from the year 496 A.D. until 762 A.D. After that date he lived in Baghdad, which was then the capital of the Saracenic Empire.

In the thirteenth century (1257 A.D.) there were no less than twenty-five metropolitan bishops under a Patriarch. Before they were all but annihilated by Timur in 1370 A.D., they had even a Patriarch of Uigur birth in the person of Yabh-allaha III., who ruled the whole Nestorian Church between 1281-1317 A.D. from Baghdad.

The following list may prove useful to those who are interested in Church history, for, although hardly mentioned in English ecclesiastical literature, the names of the Nestorian Patriarchs are historically important.*

1. Accacius . . . 496-499

2. Bahay . . . 499-502

3. Silas . . . 502-504

4. Narses . . . 504-510

5. Elias . . . 510-515

- According to the Nestorian Liturgy the following twelve names seem to occupy the period of 68 years between 428 A.D., in which Nestorius was made Patriarch of Constantinople, and 496 A.D., in which Accacius was made Patriarch :-
(I) Papa.
(5) Achad Abhay.
(9) Isaac.
(2) Abhris.
(6) Tumarka.
(3) Abraham.
(7) Shakhlupha.
(10) Achi.
(4) James.
(8) Kayuma.
(I I) Yabh-allaha I.
(I2) Dad-ishu. 
6. Paul. . . . 515-535

7. Mar Abha I. . . 536-552

8. Joseph . . . 552-567

9. Ezekiel . . . 569-580

10. Isho-yabh I. . . $58 \mathrm{I}-595$

I1. Sabhr-Isho . . 595-604

12. Gregory . . . 605-607

(During the despotic rule of King Khasure, there was no Patriarch for about twenty years.)

13. Isho-yabh II. . 628-644

(The first Nestorian mission reached China in 635 A.D.)

14. Mar Emmih . . 644-647

15. Isho-yabh III. . 648-660 16. George . . . $66 \mathrm{I}-680$

17. John Mar Math . $68 \mathrm{I}-682$ 18. John . . . . 683-685

19. Hanan-isho I. . 686-70I

20. Selibha-zeka . . 703-730

21. Python . . $731-740$

22. Abha . . . 74I-750

23. Jacob . . . 754-773

(The throne of the Patriarch was moved to Baghdad under this Jacob in $\mathbf{7 6 2}$ A.D.)

24. Hanan-isho II. - 774-780 (This name was written on the Nestorian Stone as the reigning Patriarch.)

25. Timothy I. . 780 (or 781, May)-824 (or 825).

26. Isho Bar Non . 824 (825)-827

27. George II. . . $827-832$

28. Sabhr-isho . . $832-836$

29. Mar Abraham . $837-850$

30. Theodosius . . $852-860$

31. Sergius . . . 860-872

32. Enos . . . $872-880$ 
33. John . . . 880-890 (?)

34. John . . . . 890-900 (?)

35. John Bar Highir $900-905$

36. Abraham . . . 905-937

37. Immanuel. . . 937-945

38. Israel . . . , 945-963

39. Abhd-isho • . 963-987

40. Mari-bar-Tobe . 987-100I

41. John . . . . 100I-1017

42. Isho-yabh . . . 1020-1025

43. Elijah I. . . . 1028 (?)-1049

44. John . . . . 1049-1055

45. Sabhr-isho . . 1055-1079

46. Abhd-isho . . 1079-1095

47. Makhikha I. . . 1095-I127

48. Elijah II. . . . II 28-I I 40

49. Bar Soma . . . I140-II63

50. Abhd-isho. . . $1163-1165$ (?)

51. Isho-yabh . . . 1165 (?)-1175

52. Elijah III.. . . II76-II90

53. Yabh-allaha II. . II90-I222

54. Sabhr-isho IV. . 1222-1226

55. Sabhr-isho V. . 1226-1256

56. Makhikha II. . 1257-1265

(The Abbasside Khaliph. ate ended in 1258 A.D.)

57. Dench . . . 1265-1281 (Marco Polocame to China,

58. Yabh-allaha III. $128 \mathrm{I}-1317$ May, 1275.)

59. Timothy II. . . 1318-1328

60. Dench II. . . . 1328-1 349 6r. Elijah IV. . . . 1349-1369

62. Simon . . . 1369-1380 (This Patriarch fell a victim to the arms of Tamerlane before he vanquished Sultan Bajazet in $\mathbf{1 4 0 2}$ 
When Baghdad was taken in A.D. 1258 by Hulaku Khan, grandson of Genghis Khan, the Nestorian Patriarch Makhikha II. was the object of the conqueror's protecting care whilst the last of the Khaliphs, Mostasin, was dragged through the streets and put to death.

Through the influence of the Christian Tartar princes, the Nestorian mission made great progress, and in 1281 A.D. Yabh-allaha, a Uigur tribesman, was actually elected Patriarch of the whole Assyrian Church.

But with the rise of Timur (Tamerlane) in 1358 (his birth was in 1336), the Nestorians were doomed. From 1369 A.D., when Timur was enthroned at Samarkand, till his death in A.D. 1405 the Nestorians were cruelly persecuted and almost annihilated, the majority being forced to accept Islam.

But some idea of the extent of the Nestorian communion subject to the Patriarch at Baghdad in the end of the thirteenth century, may be formed from the annexed list of their Metropolitan Sees, each having charge of several bishoprics :

1. Elamites, whose Metropolitan resided at Jandishapur or Soba in Mesopotamia (Khuzistan).

2. Nisibis.

3. Perath-Mesene (Bassorah).

4. Assyria and Adiabene (Mosul and Arbela).

5. Beth Garma or Beth Seleucia and Carcha in Assyria.

6. Halavan or Halaha (Zohal) on the confines of Medĩa.

7. Persia (Urumiah, Salmasa and Van).

8. Marw, i.e. Merv (Khorasan) (Sarakh).

9. Hara (Heliumites, i.e. Herat).

ro. Razichitis (Arabia and Cortoba).

II. Sinae (i.e. China).

12. India.

13. Armenia. 
14. Syria or Damascus.

15. Adherbijan (Bards or Aderbejan).

16. Rai and Tabaristan (Rai near Teheran on the Caspian Sea).

17. Dailam (south of the Caspian or Hyrcanian Sea).

18. Samarkand and Maravalnabar.

19. Kashgar and Turkistan.

20. Balkh and Tacharistan.

21. Segastan (Seistan).

22. Hamadan.

23. Khambling (Peking).

24. Tanchet (Tangut), N.W. of China, a country called "Great Tartary " and sometimes "Little Bokhara."

25. Chasern Garah and Nuachet.

The Metropolitan of China was an old institution. Already Arnobius wrote, about A.D. 300 : "Enumerari enim possunt, atque in usum computationis veniri, ea quae in India gesta sunt, apud Seres, Persas et Medos"; and if this hardly amounts to reckoning the Seres (i.e. Chinese) as Christians we read in the Chaldean breviary of the Malabar Church, in the Office of St. Thomas: "By St. Thomas hath the Kingdom of Heaven taken unto itself wings and passed even unto the Chinese (cf. Yule's "Cathay and the Way Thither," p. lxxxix., vol. I.); whilst we read in Assemani as quoted by Sir Henry Yule: "The Hindus and the Chinese and the Persians, and all the people of Isles of the Sea, and they who dwell in Syria and Armenia, in Javan and Rou. mania call Thomas to remembrance and adore Thy Name, O Thou our Redeemer"; and again a Metropolitan was consecrated for China in A.D. 4II, by Isaac, Patriarch of Seleucia.

In "The Book of Governors" we read: "Mar Eliya, whose history we are about to write, was elected Bishop of Mukan, David was elected to be Metropolitan of Beth Sinaje (i.e. China)-now I have learned concerning this man from 
the Epistles of Mar Timothy (78I-825 A.D.)-together with Peter his disciple, who was alive and held the office of Bishop of the country of Yaman and San'a when I was secretary to Mar Abraham (837-850)."

Mar Timothy was Patriarch between 78I and 825 A.D., so this David who was Metropolitan of China must have been the contemporary of Adam, who composed our Nestorian Inscription, and, if he went to China in the beginning of the ninth century, he may have seen this very monument. It is our conjecture that this David may have succeeded Adam, if Adam was the Metropolitan of China.

What different opinions were held by the leaders of Character- religious thought about Nestorius himself may istics of Nestorianism. be seen from the following variety of views.

For his sad fate and his upright character, Nestorius and his long-condemned doctrine found much sympathy, whilst his antagonist Cyril was censured for his violent and most un-Christian conduct.

Giesler, Neander, and Bethune-Baker champion Nestorius against Cyril and consider that he was unjustly condemned. Among English writers, Dean Milman expressed his sympathy when he said: "I would rather meet the judgment of the Divine Redeemer loaded with the errors of Nestorius than with the barbarities of Cyril" ("History of Latin Christianity," Vol. I., p. 210). Monsignor Duchesne, the greatest iiving Church historian (whose writings were lately condemned at Rome as "too historical"), after describing Cyril's abominable conduct and how low he stooped in using bribery and other similar mean tricks, concludes with pointing out the illegality of the Council of Ephesus and saying :

"Papal legates were also absent, being still en route, and the news of St. Augustine's death (whose presence had been cspecially convened) had not yet reached Ephesus; whilst, owing to the conditions in Africa, the Bishop of Carthage 
could not attend. Therefore, the Emperor himself pronounced the Council's decision to be illegal." (Translated from Duchesne's "Histoire de l'ancienne Eglise," tome 3, ch. IO, "Tragédie de Nestorius," published IgI I, Paris.)

On the other hand, some authorities vindicate Cyril against Nestorius in regard to the special problem which divided the Church of Christ in the fifth century, that is to say, the question of the Unity of Christ rather than His twofold Nature. We have already said that whilst the Alexandrian Patriarch laid stress on the mystical and speculative side of Christology, the Patriarch of Antioch emphasized its ethical and practical side.

But, however erroneous some of their theology might be, it cannot be denied that the Nestorians did excellent service in enlightening the darkness of Central Asia from the sixth to the fourteenth century when, through maritime discoveries, the Light began to reach the Eastern part of Asia by the sea-routes.

The more we study the characteristics of the Assyrian Church, the more we sympathize with her and feel how pitiful it was that the Council of Ephesus in 431 A.D. could not have been controlled, and such conduct as Cyril's (which was the reverse of Christian morality) suppressed.

Whether the Nestorian missionaries were heterodox or orthodox, it is certain that their ethical and practical theology and their medical knowledge were the true sources of their success in China.

The following points characterize their Teachings, which, with the exception of the first, no enlightened Christians of the twentieth century would condemn as heterodox!

(I) They repudiate the worship of Mary as "the Mother of God" ; this is the first point on which they differ from the Greek and Roman Catholic Churches.*

* Far be it from the author to try to elucidate the Nestorian heresy. All he wants to express is the points on which the heresy differs from the Western Church. It is needless to say that the term "Theotokos" is not to be objected to at all if properly understood (see p. 99, sufra). 
(2) They repudiate the use of images in general, although they retain the Sign of the Cross ; this is the second point of divergence between them and the Greek and Roman Churches. But this point cannot be insisted upon because the Nestorians used images (i.e. pictures) in 635 A.D., when they came to China with A-lo-pên. The Inscription says that they "brought Scriptures and images."

(3) They are opposed to the doctrine of Purgatory, but they pray for the dead and emphasize an idea of Ancestorworship, as may be seen from the Diptychs on which are written, the names of the departed. The Inscription says: "Seven times a day they perform worship and praise God and pray for the great protection of the living and for the dead." The daily services in the Church were seven in number, and the monks were careful to imitate the Psalmist, who said :

"Seven times a day do I praise Thee,

Because of Thy righteous judgments" (Psalm cxix. 164).

(4) Although opposed to the theory of Transubstantiation, they hold the Real Presence of Christ in the Eucharist.

(5) The Nestorian with the rest of the Catholic Church has always been episcopal. They have eight orders of clergy, which, according to the Nomo-canon of Abdh-isho, archdeacon (I3I 8 A.D.), are as follows :
I. The Episcopate $\left\{\begin{array}{l}(1) \text { Catholicos or Patriarch. } \\ (2) \text { Metropolitan. }\end{array}\right.$
(3) Bishop.
II. The Presbyterate $\begin{cases}\text { (4) } & \text { Presbyter. } \\ \text { (5) } & \text { Archdeacon. }\end{cases}$
(6) Deacon.
III. The Diaconate $\{$ (7) Sub-deacon.
(8) Reader.

(6) In the five lower orders-viz., priest, archdeacon, deacon, sub-deacon, and reader-they may marry, and in 
former times Bishops, Metropolitans and Patriarchs were allowed to marry. This was mainly due to their association with the Zoroastrians in Persia. The fact that the country bishops and priests had lawful wives is shewn in the following sentences on the stone :

"Adam, deacon, the son of the chorepiscopos Yesbuzid," or "Mar Yesbuzid, chorepiscopos, the son of the late priest Milis."

We are surprised to find no mention of their married life in Hsi-an-fu by the contemporary Buddhist or Confucianist writers, who must have considered it strange that some of the Nestorian priests should be married.

The Western Church borrowed Monasticism from the Orientals. Celibacy originated in Egypt, and consequently it must have influenced the Alexandrian school first. It was further encouraged by the pessimistic views of the Buddhists in India and in the plains of Mesopotamia, where Christianity very early came into contact with Buddhism.

But when the Nestorians reached Persia they could not escape the influence of the Zoroastrians, to whom the possibility of celibacy was inconceivable!

(7) The Nestorian fasts are numerous and strict. "They fast to subdue desire, and to become perfect." The seasons for these fasts are :

I. Lent.

2. The fast of the Apostles: from the first Monday after Pentecost, till the first of "the Sundays" of Summer.

3. The fast of the Migration of the Virgin (in the month of August).

4. The fast of Elijah.

5. The fast of the Annunciation.

6. The fast of the Ninevites.

7. The fast of the Virgin.

(8) They are vegetarians: the Patriarch eats no meat. This looks like a Buddhist influence; but we are told by 
Clement of Alexandria that St. Matthew, the Evangelist, was also a vegetarian, and so were all the great monks of the West.

(9) The Patriarch was chosen from the same family after I 557 A.D., but there was no such custom before the end of the sixteenth century. He was ordained by the Patriarch in Antioch as Bishop of Seleucia (the then Metropolitan), but after the sixteenth century he was consecrated by three Metropolitans.

(10) Most of the ecclesiastical books are written in the Syriac language, but they do not prohibit the use of the vernacular or that of Greek and Latin. Before the Italians took possession of North Africa the language of the Christian Church was Latin. After that date, the Latin Church in Europe and the whole West used Latin exclusively, whilst the Greek Church enforced the Greek language. The fact that the Nestorians in China used the Liturgy in the Chinese vernacular may now be inferred from the fragment discovered by Prof. Pelliot in 1908 (see the "Nestorian Baptismal Hymn," p. 66, supra).

However " heterodox" or "heretical " the Nestorians may The Nestorians as the to introduce Greek culture and Roman civilizaintroducers of Western civilization to Asia.

tion into the East beyond the Roman Orient. What Alexander von Humboldt says in his book "Cosmos" (Vol. II., pp. 579-580), may well be quoted here to illustrate what the Nestorians accomplished :

"In the more highly-gifted race of the Arabs, natural adaptability or mental cultivation, the geographical relations we have already indicated, and ancient commercial intercourse of the littoral districts with the highly civilized neighbouring states, all combine to explain how the irruption into Syria and Persia, and the subsequent possession of Egypt, were so speedily able to awaken in the conquerors a love for science and a tendency to the pursuit of independent observation. 
"It was ordained in the wonderful Decrees by which the course of events is regulated, that the Christian sect of Nestorians which exercised a very marked influence on the geographical diffusion of knowledge, should prove of use to the Arabs even before they advanced to the erudite and contentious city of Alexandria, and that, protected by the armed followers of the Creed of Islam, these Nestorian doctrines of Christianity were enabled to penetrate far into Eastern Asia. The Arabs were first made acquainted with Greek literature through the Syrians, a kindred Semitic race, who had themselves acquired a knowledge of it only about a hundred and fifty years earlier through the heretical Nestorians. Physicians, who had been educated in the scholastic establishments of the Greeks, and in the celebrated school of medicine founded by the Nestorian Christians at Edessa in Mesopotamia, were settled at Mecca as early as Mohammed's time, and there lived on a footing of friendly intercourse with the Prophet and Abu-Becker.

"The school of Edessa, a prototype of the Benedictine schools of Monte Cassino and Salerno, gave the first impulse to a scientific investigation of remedial agents yielded from the mineral and vegetable kingdoms. When these establishments were dissolved by Christian fanaticism, under Zeno the Isaurian, the Nestorians were scattered over Persia, where they soon attained to political importance, and founded at Dschondisapur, in Khurdistan, a medical school, which was afterwards much frequented. They succeeded towards the middle of the seventh century, in extending their knowledge and their doctrines as far as China, under the T'ang Dynasty -572 years after Buddhism had penetrated thither from India in 67 A.D.

"The seed of Western civilization, which had been scattered over Persia by learned monks and by the philosophers of the Neo-Platonist school at Athens persecuted by Justinian, had exercised a beneficial influence on the 
Arabs during their first Asiatic campaigns. However faint the sparks of knowledge diffused by the Nestorian monks might have been, their peculiar tendency to the investigation of medical pharmacy, could not fail to influence a race which had so long lived in the enjoyment of a free communion with nature, and which preserved a more vivid feeling for every kind of natural investigation, than the Greek and Italian inhabitants of cities. The cosmical importance attached to the age of the Arabs depends, in a great measure, on the national characteristics, which we are considering here. The Arabs, I would again remark, are to be regarded as the actual founders of physical science considered in the sense which we now apply to the words.

"It is, no doubt, extremely difficult to associate any absolute beginning with any definite epoch of time in the mental history of the world, and of the intimately connected elements of Thought.

"Individual luminous points of knowledge, and the processes by which knowledge was gradually attained, may be traced, scattered though they are through very early periods of time. How great is the gulf that separated Dioscorides, who distilled mercury from cinnabar, from the Arabian chemist, Dsiheber; how widely is Ptolemy, as an optician, removed from Alhazen; but we must, nevertheless, date the foundation of the physical and even natural sciences, from the point where new paths were first struck out by many different investigations, although with unequal success."

These words from Humboldt, the great German scholar of the nineteenth century, suffice to explain indirectly the existence of Greek or Byzantine elements in Chinese civilization.

The Nestorians who struggled for ten centuries (i.e. from the end of the fifth to the close of the fifteenth century) in diffusing Græco-Roman civilization and propagating their 
own Faith, succeeded in scattering the seeds of what, in the strictest sense, we may call "Western civilization," in Central Asia and the Far East. They had no small share in the creation of that Golden Age of China which during the seventh, eighth and ninth centuries most influenced Japan, and indirectly though it be, we are indebted to the Nestorians for some of the Western influences received about a thousand years ago.

We have now reached the most difficult part of our study. The reiation- Much has been written about the possible relationship of Nes-
torianism to Buddhism.

But as our purpose is the study of the Nestorian Monument in China, we shall not enter the jungle of this great discussion.

How far the Nestorians in China influenced Chinese Buddhism, or vice vers $d$, is the question which concerns us.

Of course, to answer this we are obliged to speak of the possible relationship of the two creeds in Central Asia, or in North-West India before either of them came to China, but for this and other related matters we must refer our readers to the valuable works by Dr. Timothy Richard of Shanghai, Dr. M. Anesaki, professor of Comparative Religion in the Imperial University of Tokyo, the late Rev. Arthur Lloyd, the Hon. Mrs. Gordon, Dr. M. Matsumoto, professor of Philosophy in the Imperial University of Kyoto, and others.

Still a slight sketch of Buddhism may not be unhelpful.

To begin with, Buddhism is professed by 450 millions of people in Ceylon, Siam, Burma, Nepal, Tibet, China, Korea, and Japan.

The Buddhism embraced by the three former countries is generally known as "Southern Buddhism," whilst that professed by the three latter is called "Northern Buddhism."

This appellation is based on the distinctive differences between the two great divisions of Indian Buddhism, which originated from the philosophical and ethical teachings of 
Siddhartha Gautama, the eldest son of Suddhodana, who was King of Kapilavasu and Chief of the Sakyas, an Aryan clan, during the fifth century B.C., on the banks of Kohana, about 100 miles north of Benares and 50 miles south of the foot of the Himalaya Mountains.

Even China and Japan possess over 5600 volumes of the Buddhist scriptures translated into Chinese, and in the old Korean temples there are innumerable satras which are absolutely unknown in Japan, and which the present Governorgeneral, Count Terauchi, is doing his best to preserve by having them copied and photographed by experts.

Ever since its introduction into Japan in the sixth century (552 A.D. or 522 A.D.), the Mahayana or Northern Buddhism has been divided into many branches, besides many more sects and several minor sects and divisions in each branch, so that it is almost impossible to compare Buddhism as a whole with Christianity, both having been divided into so many sects and sub-sects.

Even to compare any of the Buddhist writings with those of Christianity is not at all an easy matter. The innumerable legions of Christian writings are overpowered by the still more numerous army of the Buddhist writings!

It is rather dangerous to say "such and such works of Buddhism resemble such and such works of Christian writers," unless we first get a clear idea of the dates, authorship, and place of both the writings which we propose to compare.

We must first classify them according to their chronological order and then separate all that belongs to the Hinayana, the old "Small Vehicle," of original or Southern Buddhism, as that is greatly different from the Mahayana, the New or Higher Buddhism of the north, which, like Christianity-the Neo-Judaism-teaches the doctrine of Salvation through faith in a personal Saviour. In other words, the Hinayana, which is commonly known as 
"Southern or Self-salvation-Buddhism," differs very much from Mahayana, the "Northern, or Salvation-through-FaithBuddhism."

Hinayana (literally "the Small Conveyance," i.e. the simplest method of salvation), is the primitive form of Buddhist dogma, being the first stage of the three phases of development through which the Buddhist System passed, viz. Hinayana, Mahayana and Madhyimayana (the Middle Conveyance).

The characteristics of the Hinayana school are the preponderance of active moral asceticism and the absence of metaphysical speculation and mysticism. What they call their Goal of Salvation, Nimokcha (literally, "the liberation or conception of liberty") is attained through observing the strictest and most rigid rules-250 of which are recorded in the Prati-mokcha-sutra. In other words, they strive to attain "Arhatship by living the most strictly ascetic life like Gautama Buddha's personal disciples, or the Hermits who are striving to attain to Buddhaship or Enlightenment."

This Hinayana school has little in common with Christianity-although some Christian writers borrowed certain materials from Indian sources as is shown by Albert $\mathrm{J}$. Edmunds in his book, "Buddhist and Christian Gospels." This point is readily proved by the fact that the Hinayana which preceded the rise of Christianity by some five centuries, relies on self-negation and strict asceticism, whilst Christianity teaches salvation through faith in Jesus Christ whc is "the Son of man that came eating and drinking "- salvation without merit, but by faith alone.

Now Mahayana, "the Great Chariot, or Ship of Salvation," is the school founded by Ashvaghosha and Nagardjuna, which flourished chiefly in Gandara, but which afterwards influenced more or less the whole Buddhist Church in Upper Asia.

"The characteristics of this school are an excess of 
transcendental speculation tending to abstract nihilism and the substitution of fanciful degrees of meditation for the practical asceticism of the Hinayana school."

Because this, the latest form of Buddhism, developed in North-West India and spread northwards to Central Asia and beyond, it is called "Northern Buddhism."

It teaches that "Nirvana" is simply Exemption from Transmigration-the state of soul freed from either life or death and yet not far from either; that both the pains and sorrows of this life are things that lead us gradually to Bodhisattva itself-only a step from human life to Buddhahood! The cares of this life are nothing.but the Voice from on High bidding us "Children! come home"; that absolute is relative and relative is absolute; that things are not what they seem; that equality is inequality and inequality is equality; therefore, those who hold the Mahayana view of life will not be discouraged by the difference and inequality of the present, actual world, and thus they develop insight into Life's mysteries and attain "Enlightened Knowledge" in order to attain to absolutely complete morality and purity.

The 12th Buddhist Patriarch, Ashvagosha, a native of Benares, who converted King Kanishka, was formerly said to have lived 405 B.C., but modern scholars have proved the date to be in the first century A.D. (his death having occurred about the year A.D. IOO). Nagardjuna, a native of Western India, became the fourteenth Buddhist Patriarch, and together with Ashvagosha is acknowledged to be the Founder of the Mahayana School. Nagardjuna was the first teacher of the Amitabha Doctrine, but is said to have founded the Madhyamika School, a System of sophistic nihilism, which dissolves every proposition into a thesis and its antithesis and denies both.

As to the meaning of the Amitabha doctrine and its history and position in Japanese Buddhism, though much has 
been lately discovered by far-sighted writers, foreign and native, much still remains to be studied.

The Sanskrit word "Amitabha" means boundless or immeasurable Light or Life, and is rendered in the Chinese text, "Infinite Light," or "Immeasurable Life," or "Sovereign Teacher of the Western Heaven," or "Guide to the West," and sometimes as "Great Mercy and Great Sympathy," or "Embodiment of the Realm of Law."

Originally, Amitabha was thought of as impersonal, and the ideal of Infinite Light ; but gradually this abstract ideal became materialized and after being amalgamated with Sunworship in the cold regions of the north began to be a Personal expression of the First Cause, Amitabha in short became a person.

This doctrine reached Lo-yang on the Yellow River, the then capital of China, from Tokhara in Central Asia in A.D. 147. The first Amitabha Satra is said to have been translated by An-shih-kao (安世高), the heir to the Throne of Parthia, who became a monk in order that he might preach the Mahayana Gospel, and begged his way to Lo-yang.

This An-shih-kao was no less a personage than Prince Arsakes of the Arsacidae (see p. 45, supra). But unfortunately his translation was already lost when the well-known catalogue of Buddhist works translated into Chinese called K'ai-yüan-mu-lu (開元目銭) was compiled in 730 A.D.

Owing to the lack of authentic information as to its origin, and to the fact that Southern Buddhism (i.e. Hinayana) knows nothing of Amitabha, and that there are no traces whatever of the Vedic origin of the latter, many theories have been started and all sorts of conjectures hazarded, which have made the subject all the more intricate to study.

Moreover, the Buddhist traditions were so confused about the original form of Amitabha that almost any theory became possible. 
One tradition describes Amitabha as an incarnation of the Ninth Son of Mahabidjna Djnanabhibhu (which means literally "Conqueror of All-pervading Wisdom") who by means of meditation had sixteen sons. Another legend says that Amitabha was the second son of a Chakravarti of the Lunar race.

These ideas are all fabulous, but there is one theory which sounds more reasonable than the rest. It is that Amitabha, converted by a Buddha called Sahesvaradja (Free-existing-king), embraced the religious life and, having taken certain vows, was re-born as a Buddha in Sukhavati, the Paradise of the West, where Avalokiteshvara (Kuan-yin) and Mahasthanaprapta (Dai Seishi in Japanese) joined him.

In other words, Amitabha is the chief of the Three Avalokiteshvaras (觀 自 在), (lit. “On-looking (avalokita), sovereign (ishvara)," (Free manipulations), known as Ju-lai (Tathāgata) (如 來), namely, Kuan-yin, Ta-shih-chih (Dai Seishi in Japanese) and Amitabha.

Kuan-yin is the reflexion of Amitabha who, although not incarnating Himself, divides His body (分 身) and manifests Himself in visible form. He is generally known as the Saviour of the faithful (觀世音大菩蔆)一the Sovereign (Isvara) who looks on and listens to (avalokita) the voices or prayers (svara) of the world.

Mahasthanaprapta (Mahasthama), who is known as Tashih-chih-Bodhisattva (Dai Seishi Bosatsu in Japanese), is the embodiment of Amitabha's "strength," or "might," and joined Amitabha and Kuan-yin in the Paradise of the West.

Amitabha, the Father, Kuan-yin, the Saviour of the world, and Mahasthanaparapta (Dai Seishi Bosatsu) (大势至菩茏), the Spirit of Might, actually form the Buddhist Trinity.

It must be remembered that there is no Trinity in Hinayana, i.e. Southern Buddhism. 
The Trinity was a very old doctrine. It is said that Theophilus, Bishop of Antioch, who flourished in the second century, was the first who used the word "Trinity" to express the Sacred Persons in the God-head, and the doctrine it expresses has been generally received amongst Christians, and was utilized by the early Fathers of the Church, in especial by St. Athanasius, who was the Primate of Egypt.

But here is another Trinity. Now the question arises, which is the original one? Which is the older-the Buddhist or Christian Trinity? Can there be no relation at all between these ideas ? Are they "mere coincidences," as is often said ? These are the burning questions of to-day.

But all-important as they are, they belong to the preNestorian age, and therefore lie beyond our present sphere of research, which is concerned with the Nestorians and their Stone Monument in China.

The Mahā Vairochana Sutra, or Ta-jih Ching, 大日 The Nestorians in China and Vairochana.

(lit. "The Great Sun Scripture"), is the chief sûtra of one sect of the Chinese Buddhists.

Now "Vairochana" is one of the three bodies in the Three-fold Embodiment of Buddha known as "Trikaya."

There are three interpretation of this word "Trikaya." It may mean (I) the three representations of Buddha, namely, his statue," his teaching, and his stûpa (Tower or relicshrine); or it may mean (2) the historical Buddha as uniting in himself three bodily qualities, viz. Dharmakaya (the spiritual body), Sambhogokaya (the body of compensation

* Compare with this the Tower used in the Divine Liturgy of the Gallican Church.-(See Duchesne's "Origines du Culte Chretien," pp. 206-288, publ. 1908, Paris. English trans. of French $3^{\text {rd }}$ edition, London, S.P.C.K., 1910. The Emperor Constantine gave a paten of gold to the Santhran Basilica. On it was a Tower of purest gold, surmounted by a richly jewelled Dove, the whole weighing 30 lbs. - (W. Lowrie, "Christian Archeology and Art," p. 347, pub. 1906. 
reflected spiritually, corresponding to his merits), and Nirmanakaya, a body capable of transformation, i.e. possess. ing the power of assuming any form or appearance in order to propagate the Gospel of Buddha ; or (3) it may mean Buddha, as having passed through, and yet still existing in three forms or persons, viz. (A) Shakyamuni, the earthly or historical Buddha, who is endowed with the Nirmanakaya; (B) Lochana, who is the heavenly Dhyana Budhisattra endowed with the Sambhogakaya of absolute completeness in Dhyana; (C) Vairochana, who is Dhyani Buddha, endowed with the Dharmakaya of absolute purity.

The name of Vairochana appears in the last of the three interpretations about "Trikaya." If we take the third interpretation, Vairochana of the third theory corresponds to "His teaching " of the first theory and to the "Dharmakaya" of the second theory, whilst Sakyamuni answers to historical Buddha and Lochana to Sambhogakaya. So we may safely say that Vairochana corresponds to Dharmakaya (the Law Body) and that Sakyamuni corresponds to Buddha, and Lochana to Samgha-the Church-i.e. the cloistered monks and nuns.

Corresponding thus to Dharma (the Law), the spiritual and material principles of the universe, Vairochana is therefore an unchangeable or everlasting spiritual body, without beginning or end.

Comparing this meaning with that of Amitabha, "Infinite Light," "Infinite Life," or "the Embodiment of the Law," we can easily see that Vairochana and Amitabha are identical, whilst we can understand how readily those who introduced this Vairochana Religion, Ta-jih Chiao (大日 教), into Japan-first in the seventh and then again in the beginning of the ninth century-could avail themselves of Shinto, the national cult of the Land of the Rising Sun,

- According to Aston (Shinto, "The Way of the Gods," p. 316), "The Emperor Shomu of Japan dispatched Gyogi Bosatsu to Isé with a relic of Buddha as an offering to the Sun-Goddess. Gyogi spent seven days and nights in prayer 
which was based on the worship of the Sun-Goddess, Amaterasu Omikami-the God who is the Author and Dispenser of Light, and the Incarnation of Love.

When the Nestorian missionaries arrived at the capital of China in 636 A.D., there were already several Buddhist sects there; at least twelve had been in existence in China, before the end of the seventh century.

Classifying the Buddhist sects in China by their date with reference to the coming of the Nestorians to China we find that the sect (I) (涅哦宗) Nieh-p'an (Nirvāna) (386 A.D.)；(2) (成實 宗) Ch'êng-shih (4OI A.D.); (3) (律宗) Lü (Vinaya) (405 A.D.); (4) (時 論宗) Shih-lun (508 A.D.); (5) (㪴 宗) Ch'an (Dhyana) (527 A.D.); (6) (三論宗) San-lun (589 A.D.); (7) (華㗂宗) Hua-yen (557 A.D.); (8) (天台宗) T'ien-t'ai (55I A.D.), precede the arrival of the Nestorians; whilst (I) (法相宗) Fa-hsiang (640 A.D.); (2) (淨土宗) Ching-t'u (64I A.D.); (3) and (黄言宗) Chên-yen (716 A.D.) are, so to speak, post-Nestorian Buddhist sects.

And by the time the Nestorians arrived at Hsi-an-fu, the T'ien-t'ai sect had grown very strong through amalgamating the comparatively small sects of the Nirvana, Ch'êng-shih, Hua-yen, and Shih-lun.

Through the influence of this $T$ 'ien-t'ai sect, the Chinese had been already familiarized with the name of Vairochana when the Nestorian monks began their mission, and when they erected their Commemorative Monument in $78 \mathrm{I}$ A.D., the Vairochana Religion (as we know both from Kobo Daishi who was at Hsi-an-fu in 804-806 and Dengyo Daishi who was at Mount T'ien-t'ai (天台山) in 804-805 A.D.) was very flourishing through the efforts of the three great

under a tree close to the gate of the Shrine, and was then vouchsafed an oracle in the form of Chinese verse, couched in purely Buddhistic phraseology. It spoke of the Sun of Truth enlightening the long night of Life and Death, and of the Moon of Eternal Reality dispersing the clouds of Sin and Ignorances." 
monks, S'ubhak'arasimha (善無畏), Amogha Vadjra (不空金㓮), Vadjra Bodhi (金剛智), and others; and by the middle of the eighth century the Ta-jih Chiao (大日数) was all in all to the Buddhist in China.

Bearing these facts in mind, let us proceed to examine the Chinese appellation of Assyrian Christianity which is commonly called "Nestorianism." The Chinese name for this form of Christianity is "Ching Chiao" or "King Kiao." ("Ching" is the Pekingese or Northern Mandarin pronunciation.) The word "Ching " means "Luminous" or "Bright Light," and the word "Chiao" means "Teaching" or "Religion." The Inscription says : "This true and eternal system of doctrine is wonderful, and difficult to describe. But its merits and use are manifest and brilliant; and so we make an effort and give it the name of 'Ching Chiao' (Luminous Religion)."

We said that the Vairochana Religion was known in China and Japan at that time as the Dai Nichi Kyo, or Ta-jih Chiao (大日教), which means "The Great-SunReligion."

From the similarity of the characters used to represent them, the "Ching Chiao" or Assyrian Christianity, and the "Ta-jih Chiao," the Vairochana Religion, are likely to be confused. To the educated Chinese who could read and write the different Chinese characters the two names must have been far more perplexing than to the illiterate classes for the following reasons :

Great scholars like Dr. Legge, $\mathbf{M r}, \mathrm{Wylie}$, and others are all agreed in translating the Chinese word "ching" (景), by "illustrious" - "Ching Chiao," the "Illustrious Religion." This rendering is partly correct, because “Ching” (景) corresponds, in its secondary meaning, to the English word "brilliant." But we must remember that the original and chief meaning of the word "Ching " (景) is "great," and not "illustrious." 
This point is important. This can clearly be seen from the fact that the Chinese character "Ching" (菆) was not given for the English word "illustrious" in "The English and Chinese Dictionary" (英華字典), edited by the famous scholar, Lobscheid, some sixty years ago. He correctly gave the Chinese character "Ching" (景) for the English word "great."

Again, in the Book of Shih-ching (詩 經), the Chinese Book of Songs, we frequently meet with the phrase "Ching-fu" (景福), which means, literally, “the great happiness," or "great blessing," "ching" standing for "great" and "fu" for "happiness" or "blessing."

So "Ching Chiao" at first sight may mean "Great Religion," but to understand the true meaning of the term as used by the author of the Inscription, we must go deeper, and dissect or analyze the Chinese character itself and examine its component parts, which are, in this case, two independent characters, viz. the character "Jih" (日), "Sun" and the character “ching” (京), " great." This “ching"(京) being the root, so to speak, of the other "ching" (景), its sound predominates even after "Sun" and "Ching" composed one word-the other and newer word "Ching" (景) being the name used for the Assyrian Church in China.

- From these facts, it may be surmised that "Ching Chiao" (the name for the Assyrian Christianity) not only meant "Great-Religion," but also "The Sun-Great-Religion!" which appellation is practically the same as the Chinese name given to the Vairochana Religion, "The Great-Sun-Religion!"

That the Chinese character "Ching" (景) contains the two characters, "jih" (日) and " ching” (京), there is no doubt. But a few words may be needed to prove that "ching" (京), the root of the other "ching " (景), which is a component part of the Chinese character used to represent Assyrian Christianity (景教), truly and honestly means "great" as we insist, because some may consider our explanation too far-fetched. 
All that can be said on this point is clearly set forth in the famous “ $K$ 'ang-hsi Dictionary" (康照字典), which states: "The character (京) is pronounced 'ching' and means 'great' (京軘整大也)."

Again, in one of the writings by the famous scholar Yang Hsiung (揚雄) in the second century A.D. we read : “In the North of Yen (燕) and in the country of $\mathrm{Ch}^{\prime} \mathrm{u}$ (焚), a great man is called 'ching' (京), i.e. 'ching' means a great man in Yen and Ch'u. And again, the Royal city or Capital where an emperor or a king resides is called 'Ching-shih' (京 in Chinese. In this case, 'ching' stands for 'great' and ' shih' for 'population' or 'crowd.' And finally, the greatest possible numerical name in Chinese is 'ching' (京); ten

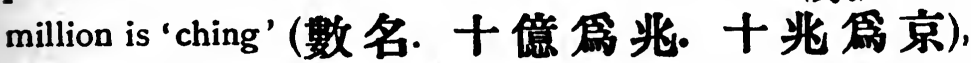
but one million is 'chao' ( 光) ; whilst two Chinese characters, 'fish' and 'great,' make up the character of 'whale' (倞), i.e. (鮭 fish, 京 great)."

These quotations from reliable authorities suffice to prove that “ching" (索), part of the character “Ching” (寞), which is used to represent the Assyrian Church, truly and honestly means "great," and that what we say about the name of "Ching Chiao," is not, perhaps, too far-fetched.

To return to our former question, "Which is the older, the Ching Chiao or the Tah-jih Chiao?" The name Ta-jih Chiao is older than the term "Ching Chiao" by twenty years at least, for the word "Ching Chiao" was certainly not in use until A.D. 745, whilst, so far as can be ascertained from the Chinese writings, "Ta-jih Chiao" was used in the translation of the Vairochana Sutra as early as A.D. 724.

To call one foreign religion "Ching Chiao," and the other "Ta-jih Chiao" made no difference to a Chinaman in Hsi-an$\mathrm{fu}$, who would perceive no more difference between the Buddhist and Christian religions than did the European Friars and travellers in the Middle Ages who (as Sir Henry 
Yule tells us in his book, "Cathay and the Way thither") constantly made the same confusion owing to the great similarity between Buddhism and Christianity in Central Asia!

It seems to us that the Nestorians in China, in adopting the title "Ching Chiao"- "Sun-Great-Religion" "-availed themselves of the existing influence of the Vairochana Religion which was then extremely strong in Hsi-an-fu.

The Nestorian Church, commonly known in China as "the Persian Religion," or "the Messiah-Religion," was first called "the Persian Ching Chiao"-_" the Sun-Great-Religion of Persia "-in the Imperial Rescript of the Emperor HsüanTsung in A.D. 745.

In short, Vairochana Teaching was introduced into China as early as 575 A.D. When Chih-k'ai developed the $T$ 'ien-t'ai sect, he based his teaching on the Saddharmapundarika Sutra (法華經) (Japanese Hokekyo) whose supreme Buddha is Vairochana, but the Chinese name "Tajih Chiao" (大日教) for Vairochana did not come into use until 725 A.D.

It is said that this Vairochana transmitted his teaching to Sakyamuni, who again transmitted the same to Maitreya, the Buddhist Messiah; whilst Maitreya taught Asamgha, a monk of Gandara, who was miraculously transported to the Heaven of Joy where Maitreya dwelt; and through Asamgha's lecture-hall this teaching of Vairochana became known to the world, so the Buddhist authorities say. The date of Asamgha, as being the last half of the fourth century, is important.

* Luminous religion. A penny of Ecgfrith, King of Northumbria, A.D. 670685, bears a radiated cross, and the one word "LUX" or Light, thus pointing very expressively to the recent introduction of the light of Christianity into the north of England by Paulinus, in the time of King Edwin, and sweetly suggesting the declaration of the Lord Jesus, "I am the Light of the World : he that believeth in Me shall not walk in darkness, but shall have the Light of Life." (From p. 22 of a most suggestive handbook published by the S.P.C.K., IgIr, entitled "Christian Teaching of Coin Mottoes," by Dr. Wm. Allan and Prof. J. Zimmermann.) 
The T'ien-t'ai sect (天合宗) maintains these points about Vairochana as against the Chên-yen sect, which declares that the revelation was made to Nagarjuna * through the prison or cage in the "Iron Tower in Southern India." +

Whether the T'ien-t'ai or the Chên-yen claim is correct does not concern us very much. But it is certain that the Nestorian claim in China does not go further back than 635 A.D. So it is safer to conclude that the Nestorian missionaries adopted the name "Ching Chiao" long after the Vairochana Religion had become "Ta-jih Chiao."

We presume that one of the many difficult problems which faced the pioneer missionaries of the Assyrian Church in China, twelve hundred years ago, was to find a suitable name by which to describe their teaching to the Chinese. "The name of a thing," as the Chinese sage taught his disciples, "is the guide to the thing itself." To find a suitable name is a good beginning; and a good beginning means the work half done.

At least three rules might have guided us in a similar position: (I) To find a suitable name to describe the Religion of Jesus Christ who is the "Light of the World," and "the Sun of Righteousness."

We note this feeling expressed in the Inscription: "Its merivs and use are manifest and brilliant" ; "He hung up the Bright (great) Sun and broke open the abodes of Darkness." Any name which does not express this truth is not a good one.

(2) The Nestorian monks must have considered how best

* It is important to note that some authorities affirm that it was not in Southern India but at the Great College at Khotan on the Central Asian route that Nagarjuna obtained his Mahayana teachings.

† For full details refer to "The New Testament of Higher Buddhism," by Rev. Timothy Richard, D.D., LL.D., pub. Edinburgh, and to "The Messiah, the Desire of all Nations," and to "World-Healers, or the Lotus Gospel and its Bodhisattras," by the Hon. Mrs. Gordon, pub. Tokyo, 1913. 
to preserve the sound of " $\mathrm{K}$," the first sound of the word"Christ" or "Christian," for it was at Antioch, the capital of Syria (and the Christian metropolis after the Fall of Jerusalem), that our Lord's disciples-" the Men and Women of the Way"-were called "Christians."

"Antioch," says Prof. A. Harnack, "was a great city for giving nicknames. Here Christ was called 'Chi,' whilst Constantine the Great was nicknamed 'Kappa.'"

For these monks then who came from Syria, it was most natural that they should try to preserve the " $k$ " sound in the title of their religion. "Ching Chiao" was the right name for Christianity according to its sound, because "Ching" was pronounced "King" in the eighth century as all students know ; and even now the sound of "King" is preserved for the same character in Southern China.

(3) The monks must have pondered how best to fortify their position against the Confucianism, Taoism, and Buddhism, then so very strong and firmly rooted in the field. Humanly speaking, the success or failure of a Mission in a foreign field largely depends on the name by which the new Religion is known. By adopting the name of "Ching Chiao" (with the old sound “King-kiao" (景教), “SunGreat-Religion," the Nestorian missionaries could at once fulfil all these three conditions.

Moreover, the Syriac monks adopted ordinary Buddhist terms to represent “Catholicos" (法主), “Episcopos” (大德), “Monk” (箱), “Archimandrite or Archdeacon" (寺主), “Monastery” (寺), “Scriptures" (經), “Image” (經像), etc. Dean Stanley, in his "Eastern Church," points out that all these ideas came to Europe from the East.

Even the epithet commonly used for Sakyamuni (世 㖊), i.e. "Honoured by the Universe," or "World-Honoured One,". was employed by the Syrian missionaries to describe our Lord. 
Again, the three Chinese characters used for "Eloha" in the Inscription (阿羅訶) are, no doubt, taken from the Buddhist Scriptures in which "Arhat" or "Arhan," "the Fruit of Buddha," is represented as "A-lo-han."

In the Chinese translation of the Amitayur Dhyana Sutra we find exactly the same words as are used on the Nestorian Stone. (是故當一心繁念諦觀彼佛多陀阿扸 度阿羅訶三蕧三佛陀佛說觀無量壽經), which may be translated :

"Therefore, meditate ye with all your heart and vividly realize ye that Buddha, who is known as Tathagata (the Coming One, i.e. 如 來), or as Arhat, the One who deserves worship (度供), or as Samyak sambuddha (三䅐三佛陀), the One who has perfect and universal knowledge." (See p. 188, note 8.)

Through these and other facts, we perceive how keen and zealous the pioneer missionaries of the Assyrian Church were in trying to win souls for Christ. Surely, in coming to China, braving the dangers of the Great Desert and travelling so far, they followed the example set by that great Apostle to the Gentiles, who said: "That I may by all means win some, to the Jews I became a Jew, and to the Greeks, a Greek." Hence it is no wonder that the Nestorian missionaries in China succeeded so well twelve hundred years ago.

From A.D. 67 when Buddhism was introduced into China The Ancestor- after King Kanishka's great Council at Gandara worship of up to A.D. 1097 when the famous Ou-yang Hsiu Buddhism, and the incinence exer- is said to have been converted to Buddhism, there by Assyrian was a period of over a thousand years, during which Christianity. Buddhism in China suffered four serious persecutions known in Chinese history as "The Persecutions of Three Wu emperors and One Tsung" (三武一宗之難), who respectively in the years 446 A.D., 547 A.D., 845 A.D., 955 A.D. severely persecuted the Buddhists. 
Buddhism was hated by Confucian scholars, and despised by the Taoists. With such extreme vicissitudes, the fate of Mahayana Buddhism was far from promising. Indeed it was extremely doubtful whether it would ever establish itself at all.

The grounds for the anti-Buddhist movements in China were fairly numerous. But one thing is clear, viz. that both Confucian scholars and Taoists made very good use of Ancestor-worship to inflame the popular prejudice against Buddhism.

It may be readily understood how the feeling towards Ancestor-worship, which is ingrained in the hearts of the Chinese, was antagonistic to the pessimistic and ascetic ideas of the original Hinayana Buddhism.

Certain scholars (Dr. S. Murakami, for instance) attribute the four above-mentioned great persecutions to the Taoists only; but to the writer, it seems that the Taoists simply took advantage of the anti-Buddhist sentiment of the populace and utilized the dominant feeling concerning the national cult to serve their own ends. Without this antagonistic feeling, the Taoists could scarcely have been so successful in ousting the Buddhists.

The chief hindrance to the propagation of Buddhism in China was its attitude towards Ancestor-worship, which by no means satisfied the Chinese. The Buddhist teaching about the After-death was abhorrent to the Chinese, e.g. the Buddhist mode of treating the dead, cremation being the most unwelcome of things in China. Chinese scholars often express their horror of it.

Buddhist influence, however, was in the ascendant ever since the second persecution in 547 A.D., as the Emperors both of the Sui Dynasty and of the early T'ang favoured it ; and from the close of the seventh to the opening of the ninth century Buddhism carried all before it-the Buddhists eclipsing both the Confucians and Taoists in Imperial, as as well as in popular, favour. 
This is incidentally confirmed by the fact that many of the Chinese classical writings have obtained the Imperial sanction to be called by the title of Canonical Works.

For example, Wên-chung's writings (文中子) were named "The True Sûtra of the Enlightened Mystery" (通立眞經); Lieh-tzŭ's writings (列子). were entitled “The True Canon of Ascension into the Void" (冲虚真 經) ; those of Chuang-tzŭ (誑子), “The Canon of Nan-hua” (南華葚經), whilst Han-shan-tzŭ's collection of Poetry (寒山子集) found its way into the Chinese Collection of the Tripitaka, the Buddhist Canon! This proves how everything was tinged with Buddhist colouring during the seventh and eighth centuries, and how strong the influence of Buddhism was in those days!

Meanwhile, a great number of Buddhist Sûtras were brought into China by the efforts of Hsüan-tsang (立 奖) (633 A.D.), Vajra Bodhi (金凨智) (719 A.D.), Subhakarasima (善無畏)(716 A.D.), Amogha-Vajra (不空金用) (7 I9 A.D.), Prajna (磐 若) (782 A.D.) and others who translated and wrote commentaries on some of them.

Never in the history of Missions do we find a more active man than Amogha was in using his pen in translating or in copying the sûtras. Nor was there ever a better field than the capital of the Great T'ang for the appreciation of foreign literatures.

There were numerous reasons for this growing influence, such as the personal character of the Buddhist leaders, and the amount of foreign intercourse at the time which disposed the minds of the Chinese to listen to the foreign teachers of Religion. But over and beyond these minor, indirect, causes, the increased popularity of Buddhism was (we think) mainly due to a compromise effected by the Buddhist leaders who, desiring to harmonize their religion with the old Chinese cult of Ancestor-worship, succeeded in overcoming the antiBuddhist feeling (so long a stumbling-block in their way) 
by adopting and adapting Ancestor-worship in such a way as to meet the Chinese sentiment.*

Making a new departure from their original custom, Buddhists led the way in harmonizing the ancient Chinese Ancestor-worship with Buddhism, and thus brought Ullambana (于 蘭盈), the "Festival of departed Souls," and the worship of Vairochana into kinship with the old national cult, and with that of the Sun, Moon, and Stars, the "Heaven" of the Chinese. $\dagger$

This fact can be better appreciated through comparing the similar harmonization effected between Shinto and Buddhism by those Japanese monks-Gyogi Bosatsu, Kobo Daishi, and others-who had studied passing events in China. The Honchi Sui Jaku (本地垂迹), “Re-incarnation of the same Sage in different lands," or "The theory that a Sage has no fixed name," and the Ryobu Shinto, "the harmonization of Buddhism with Shinto by compromise," were introduced into Japan as the result of the concordat between Buddhism and the old Chinese cults in China and Japan.

With regard to the introduction of Vairochana worship, we may mention Dharmaraksha and Kumarajiva who respectively translated the Saddharmapundarika Suttra in 286 A.D. and 406 A.D., and Jnanagupta and Dharmagupta who respectively translated the same Satra between 56I-592 and 5906I6 A.D., and those who translated the Commentaries on the Saddharmapundarika Sutra-Bodhiruchi and others between 486-534 A.D.; Ratnamati and his monks in 508 A.D., whilst Amogha-Vajra stands above all others in popularizing "the Festival of departed Souls," and in harmonizing Indian Buddhism with the Chinese ancestral worship. $\ddagger$

* It was for the express purpose of endeavouring to harmonize Religion that the Japanese emperor Kammu sent the young scholar monks Kobo Daishi and Dengyo Daishi to China.

+ Cf. the statement in the great T'ang emperor's Edict concerning A-lo-pên and his monks A.D. 638.

$\ddagger$ "Compare this with the celebration of All Saints which was extended to 
Amogha-Vajra, " the Vajra which is not hollow" (known in China as Pu-k'ung Chin-kang, and Japan as Fuku Kongo (不空金剛)), was a Sramana (monk) from North India, who followed the mystic teachings attributed to Sumantabhadra (普賢), and accompanied his teacher Vajra Bodhi

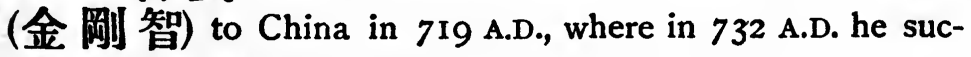
ceeded him as Patriarch of the Yogacharya school.

As the Chinese Emperor desired to have some more new Buddhist scriptures-many having been lost on the voyage when Vajra Bodhi and Amogha came to ChinaAmogha travelled for five years $(741-746)$ through India and Ceylon and brought back to Ch'ang-an (i.e. Hsi-an-fu) over five hundred Sutras and Sastras previously unknown to the Chinese Buddhists. He published 108 works from his own pen, including translations and originals.

Amogha had spent fifty years or more in China before he decided to establish "the Feast of departed Souls." $\mathrm{He}$ served three emperors, viz. Hsüan-Tsung (713-756 A.D.), Su-Tsung (756-763 A.D.) and Tai-Tsung (763-779 A.D.).

It was Hsüan-Tsung who would not permit Amogha-Vajra to return to India in 749 A.D., while it was Su-Tsung who gave him the title of Tripitaka Bhadanta (大廣智三藏) in 760 A.D.; and it was Tai-Tsung who conferred on him the rank of a Minister of State (司 空), and the highest posthumous title when Amogha died in 772 A.D.

These three emperors all received Murddhabhichikta from him. This Murddhabhichikta, according to Dr. Eitel, literally means "the washing of the head" (灌頂), and is done by sprinkling water on the crown. This is "a ceremony common in Tibet in the form of infant Baptism" as practised

the Frankish Empire in 825, after having been observed in Rome for two centuries, and its celebration fixed for the Ist November, the verse 'gentem auferte perfidam credentium de finibus' was added to the hymn with reference to the Normans and Saracens, who were laying waste both the north-west of Gaul and the south of Italy."- "The Roman Breviary, its Sources and History," pp.68, 240, 251, by Dom Jules Bandot, pub. 1909. 
in Christian churches, but administered in China and Japan at the investiture of distinguished patfons of the Shingon sect. The relation between Kechien-Kwanjo, i.e. "to-make-relationship-with-Buddha-baptism " of the Shingon-shu or Chên-yen sect-which may be received by any one and which resembles Infant Baptism-and Christian baptism offers a most suggestive subject for study. A chapter in the Hon. Mrs. Gordon's book, "World-healers," entitled "The Mystery of Illumination," is devoted to it.

Like all the great Pioneer Monks of the West, Amogha Vajra was a friend of the Court as well as of the peasantry. From his long experience in China and intimate study of Chinese thought and literature, he perceived quite clearly that it was impossible to win the Chinese masses to Buddhism unless he could discover some means of winning their sympathies by utilizing the national cult-in particular Ancestor-worship, on which all their moral systems (whether Confucian or Taoist) hang-and harmonizing it with the teachings of Buddhism; he therefore resolved to revive the Ullambana festival of departed Souls.

This feast is now kept annually in July (the seventh month of the Old Style) in both Buddhist and Taoist temples. No other religious festival is so popular, and the reason is not far to seek; it appeals to the tenderest feelings in the human heart.

The Ullambana Sûtra (first translated by Dharmarakcha. a native of Tokhara, between 265-316 A.D.), gives to the whole ceremonial the so-called authority of Sakyamuni and supports it by the alleged experiences of his chief disciple Ananda, who was said to have appeased pretas (餓鬼), the unrestful departed souls, by food offerings presented to Buddha and Samgha (the cloistered monks). It was by this means that Maudgalyayana (目別畧) brought back his mother to earth, who had been reborn in Hell as a Preta. (See Dr. Eitel's Hand-book of "Chinese Buddhism," pp. 185-186.) 
But prior to the end of the seventh century, its growth was slow and tedious. It was popularized mainly through the far-sighted and deeply-instructed Buddhist leaders, such as Amogha Vajra and others who succeeded in reviving and giving the institution a special impetus, whilst the popularity of the influential Yogacharya School helped Amogha and his missionary friends greatly in carrying out his plan.

But it must be remembered that all authorities agree that the whole theory of Ullambana with its ideas of intercessory prayers, priestly liturgies, requiems, and Ancestor-worship is entirely foreign to the ancient Hinayana, or Southern Buddhism, and is peculiar to the Mahayana.

Thus Amogha proved negatively to the Chinese mind, that although Buddhism approves of cremation, it does not neglect the dead. Again, he proved positively that the Buddhists do honour the dead more than the Confucians or the Taoists who can do nothing for their parents after death, or in the life beyond the grave when their parents are in Purgatory, by proving that in " the Festival of departed Souls" the Buddhists fulfilled the ideal of Ancestral worship far better than either Confucianists or Taoists could do ; and hence he succeeded in establishing what is now known as "Chinese Buddhism" apart from Indian Buddhism.

Ḧsuan-tsang (立 禁), the Chinese Pilgrim, successfully introduced Indian Buddhism into China, while an Indian monk, Amogha Vadjra, succeeded in grafting Chinese Buddhism upon the Chinese cult !

If we compare Hsüan-tsang with Gyogi Bosatsu (行基菩薩), or with Kobo Daishi (弘法大師), who so successfully introduced Chinese Buddhism into Japan, we may also compare the work accomplished by Amogha Vadjra with that of Shinran and Nichiren Shonin who succeeded in making Japanese Buddhism a thing apart from either Chinese or Indian Buddhism.

When Amogha Vadjra arrived in China, it was the period 
in which almost all the elements of culture were being introduced into Japan from China. Ever since A.D. 607 when the first Japanese envoy, Ono-no-imoko (小野妹子) and his party were sent to China, numbers of young Japanese had been sent there by the Japanese Government to study until 894 A.D., when the famous Sugawara-no-michizane (菅原道䢐), having been appointed as Envoy to Ch'angan, was prevented from going by the great war in China.

When Kobo Daishi and Dengyo Daishi went to Chinathirty years after Amogha's death-" the Festival of departed Souls " was at the height of its popularity. No wonder then that this Ullambana-O-Bon-Matsuri-was at once popularized in Japan by these monks on their return from China, and that thereby the propagation of Buddhism was greatly facilitated among the Japanese who had been repelled by the anti-ancestral attitude of Buddhism. The majority of the Japanese could not tolerate the idea of cremating one's father or mother. Neither could they conceive how their beloved parents could be in Purgatory.*

But the Feast of departed Souls was the very weapon that the Buddhist missionaries required to overcome this opposition. That Buddhism, taking Chinese colour and adopting the national cult of Ancestor-worship, took a leaf from the Assyrian Christians' book may be fairly conjectured from the fact of their mutual friendliness ; the Buddhist teachers would naturally observe that the Assyrian Christians offered prayers both for the living and for the dead seven times a day, as mentioned in the Nestorian Inscription by Adam (景淨), who composed it and also co-operated with Prajña, the Kashmir monk, in Hsi-an-fu, in translating a Buddhist Sutra as already described.

The Inscription on the stone tells us how the Emperor Hsuian-Tsung, who was an intimate friend of Amogha and

* St. Francis Xavier found the same feelings when he came to Yamaguchi in Japan in A.D. 1552 . 
had received the Buddhist Baptism from him, was a generous patron of the Nestorian Convent.

It also describes how Su-Tsung rebuilt the Nestorian temples, and how Tai-Tsung (who gave Amogha a very high posthumous honour) was so amiable as to invite the Nestorians or "Luminous People" to his birthday party. These are convincing proofs of the Imperial friendliness to both religions-Nestorian Christianity and Buddhism.

The Inscription says: "Hsüan-Tsung (713-755 A.D.), the 'Emperor of the Perfect Way' ordered Prince Ning-kuo (管國 王) and four other Imperial Princes to go to the Blessed Building (i.e. Church) and rebuild the altars.

"The consecrated beams which had been torn away from their places were thus again set up, and the Sacred stones which had been thrown down were replaced. In the beginning of the Period T'ien-pao (742-755 A.D.), orders were given to the Great-General Kao Li-shih (高力士), to send faithful portraits of the five Emperors and have them placed securely in the monastery with a gift of a hundred pieces of silk.

"And again, in the third year of the same period (744 A.D.), in the Kingdom of $\mathrm{Ta}$-ch'in there was a monk called Wagis (i.e. George) (种吉), who came to pay homage to the Emperor. An Imperial proclamation was issued for the

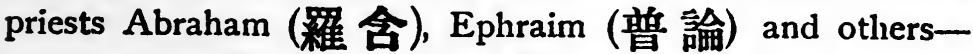
seventeen in all, along with the Bishop George to perform a service of merit (i.e. thanksgiving and prayer) in 'the Hsingch'ing Palace' (與度宮).

"The Accomplished and Intelligent Emperor Su-Tsung $(756-762$ A.D.) rebuilt the Convents of the Luminous Religion in the five districts of Ling-wu (靈 武) and elsewhere.

"The Emperor Tai-Tsung (763-779 A.D.), accomplished and martial, gradually signalized his ascension to the throne, and conducted his affairs without difficulty. Always when 
his birthday recurred he presented celestial incense wherewith to announce to Heaven the meritorious deeds accomplished by him, and sent provisions from his own table to gladden (or do honour to) the congregation of the Luminous Religion."

These quotations from the Inscription show how much the Chinese Emperors favoured the Assyrian Christians, and may suggest that "the Imperial Birthday Festival "- "praying for the living" - which was instituted in A.D. 729, was of Nestorian origin, and that what is written in Nien Ch'ang's "Biographical History of Buddhism" about the Emperor Tai-Tsung's having had a service performed likewise by a large company of Buddhist monks on his birthday, means that the Buddhists were admitted to the ceremony for the first time in 765 A.D. whilst, according to the Chinese Annals, a number of Confucian scholars were for the first time admitted to this ceremony in 797 A.D.

We in Japan had very much the same Festival instituted in 775 A.D. for the first time, i.e. forty-six years after it had been started in China, and twenty-nine years after the visit of a Persian physician whom we have identified with Priest Milis of the Nestorian Inscriptior. Besides, we have another ceremony of public prayer, which was introduced by Kobo Daishi, and continues to this day. This prayer service is held at the Imperial Palace in behalf of the Emperor's long life. Formerly this special prayer was offered on His Majesty's birthday, but the celebration now takes place at the New Year, usually in the second week of January; the privilege of conducting the service given to Kobo Daishi was confirmed to his successors, the monks of the Shingon shu, in whose hands it still remains.

All the testimonies from China and Japan agree that Assyrian Christians and Buddhists were on exceedingly good terms in China, and that they learned and imitated one apother's good points even if they were not actually one and the same in Faith, as some scholars have supposed. 
Both being foreign religions which sometimes enjoyed the same Imperial patronage, and at others suffered the same persecutions, they were, as a rule, sympathetic to each other. We may venture to say that the Assyrian Christian missionaries throve under the wings of Buddhism, whilst the Buddhists, under the leadership of so great and broad-minded a teacher as Amogha, availed themselves of some Nestorian usages.

Prayers for the dead and the use of "I-hai" (位牌) or “Rei-hai" (靈牌), that is to say diptychs, may have been learned by the Buddhists from their Nestorian friends, for this prayer for the dead, like their " prayer for the living," was one of the characteristics of the Assyrian Church as well as a Jewish custom which is continued in the synagogues to this day. Nay, more, it was the established custom in the whole Catholic Church until it was ignored by the Protestant Reformation in the sixteenth century.

The Inscription says: "Seven times a day they meet for worship and praise for the great protection of the living and the dead." "Those who are living flourish; and those who are dead have joy." "The dead are buried and laid to rest in their graves." "To save both the quick and the dead, the Ship of Great Mercy was launched." "Both the quick and the dead safely sailed over to the other side " (of the River, i.e. of Death, or what the Buddhists term " crossing over the Ocean of Sin and Sorrow to the Further").

Such passages prove that the Assyrian Church in China found no necessity to attack either Confucianists or Taoists about their Ancestral worship ; on the contrary, they met on common ground! The Nestorian prayers for the dead and the Ancestral worship of Confucianists and Taoists were strong enough to influence any such far-sighted leaders as the Buddhist Subhakarashima, Vajra Bodhi, Amogha Vajra, and others to popularize the "Feast of departed Souls."

It is impossible to imagine that Amogha Vajra, the 
favourite of three Chinese Emperors, was so inhuman as to be unmoved by the prevalent feeling. Nay, it was essential for him, or any other Buddhist leader, to defend Buddhism against the attacks from outsiders who said that "Buddhism does not teach respect for Ancestors, as they even cremate the dead."

The Feast of departed Souls and the influence of the GreatSun-Worship of Vairochana, as the Light and Saviour of the World, were extremely flourishing and popular during the eighth century in China, and even at the time when our Kobo Daishi went to Ch'ang-an at the beginning of the ninth century.

This Feast of departed Souls, the chief characteristic of Chinese and Japanese Buddhism, is one of the most conspicuous indirect results produced by the presence of the Assyrian Christians in China, and is an equally prominent usage amongst the descendants of the ancient Celtic Church in Brittany as well as in Italy, and other Roman Catholic countries down to the present day.

The Festival must have seemed a strange innovation to the Southern Buddhists who clearly and distinctly professed that "No man can be saved by another; he must save himself." "Buddhism teaches the highest goodness without a god; a continued existence without what goes by the name of soul ; a happiness without an objective Heaven ; a method of Salvation without a vicarious Saviour; a Self-redemption, without rites, prayers, penances, priests, or intercessory saints; and a summum bonum attainable in this life and in this world." ("Buddhist Catechism," by Col. Alcott, pp. 25, 33.)

Evidently "the Feast of departed Souls" is entirely unknown to the Orthodox Canon of Southern Buddhism! But how this Mahayana Festival of departed Souls and prayer for the dead and the dying, which are thoroughly Catholic teachings, came from contact with the Assyrian Christians in China is a most important problem, and as yet unsolved. 
Monsignor Duchesne says that "the most characteristic trait in all Liturgies of Nestorian origin, is the place assigned to the great Intercession or Memento ; instead of following the epiclesis as in the Syriac liturgy, it is placed before and attached immediately to the Commemoration of the Christ or Anamnesis" ("Origines du Culte Chrêtien," p. 70, pub. Paris, 1908 ; English ed., S.P.C.K., 1910, p. 70).

So much for the relation between the Nestorians in China

Possible relation of the Nestorian Influence in China to the marriage of priests in . Japan.

and Chinese Buddhism. During the eighth and ninth centuries, there was scarcely anything good in Hsi-an-fu, the great $T$ 'ang capital, that was not introduced into Japan or copied by the Japanese in their capital at Nara sooner or later.

If the Court buildings in Hsi-an-fu were painted red, so were those at Nara. If a temple was built and supported by the Chinese Government in each province, so must it be in Japan. If the birthday of the Chinese Emperor was observed as a National Holiday in China, so was it here. If the nobles and upper class in the Chinese capital played football, it was soon imitated by the Japanese aristocracy in Nara, and Asuka-oka.

Strange as it may sound to a foreigner, and still more so to our own Japanese people, it is not altogether unreasonable to suppose the old Japan prior to the thirteenth century as if she were a part of China so far as her culture and civilization were concerned!

We can trace it all back to the Chinese origin of Japanese Buddhism. It was after Kublai Khan's invasion (1268I28I A.D.) that Japan began to realize her spiritual as well as material independence. By her great victory over Kublai, Japan shook off the spiritual yoke, so to speak, of Chinese civilization, and a strong national consciousness arose. Before the thirteenth century, Buddhism never took the form of a Japanese Buddhism. This fact in Japan's religious history corresponds to other facts in her national history. 
Art and literature began to take a Japanese form about the same time.

But the influence of China was so strong that after the long space of nine hundred and fifty years those Japanese who studied Buddhism only through Chinese translations at last began to think that for the study of Buddhism the Chinese texts and Chinese commentaries were enough. They did not see any land beyond China.

In the thirteenth century the study of Sanskrit was quite neglected by Japanese Buddhists. When the great Shinran and Nichiren created Japanese Buddhism out of Chinese Buddhism, it was a time when Japan was least influenced by things Chinese.

It was after the glorious Japanese victory over Kublai and his Tartar hosts in 1281 A.D., that Japan became the true preserver of the Cha'ng-an civilization.

We find many things in Japan which have long been lost in China. For example, there are several ancient Chinese books which are preserved only in Japan; some musical instruments, like the biwa, which have almost obsolete forms in China, although well preserved in Japan ever since Fujiwara Sadatoshi (藤原貞敏) introduced them into the country in 893 A.D.

Similarly in Religion. Some of the Buddhist sects lost in China developed here in Japan on different lines. The strongest sects in Japanese Buddhism all belong to the Mahayana school whose central points are diametrically opposed to those of Southern or Hinayana Buddhism, whether found in China or in India.*

Among the Buddhist sects in Japan the Shin-shu (i.e. True religion, 真宗) canonically allows its priests, or ordained men, to marry. This sect was founded by Shinran in 1224 A.D. But his teacher Genku, better known as Honen Shonin

* Shingon shu has 17,538,859 ; Shin shu, 13,325,619 ; Sodo shu, 9,681,612 ; Jodo shu, 3,913,051 ; Rinsai, 2,268, 222 ; Tendai, 2,078,424 ; Nichiren, 2, 163,809 (The Government Report for 1912). 
(1 133-1 208 A.D.), who introduced the Jodo-Shu (Sukhavati, i.e. "the Paradise-of-the-West," sect) into Japan had already permitted Shinran to marry. This was not the Ordination of the married man, but the marriage of the ordained man.

The historians of this sect agree in saying that Shinran had two teachers in Japan, three predecessors in China, and two Boddhisattvas in India. The two Japanese teachers of Shinran were Genkū (源 空) and Genshin (源 信), and his three Chinese predecessors were Yün-luan (雲 (導綽), and Shan-tao (善導), whilst the two Boddhisattvas were Vasubandha (世 親), a disciple of Nagarjuna, and Nagarjuna (龍樹) himself-the great teacher of the Amitabha doctrine.

Nagarjuna having died about the middle of the second century A.D., the Japanese Buddhists trace back to Sakyamuni and thus lay claim to their own "Apostolic succession."

Sakyamuni (450 B.C.).

Ashvaghosha (died I00 A.D., but is traditionally claimed to have died in 405 B.C.).

Nagarjuna (died I94 A.D., some say that he died in 120 A.D., while others I 50 A.D.).

Vasubandha (345 A.D., some say that he died in 445 A.D.).

Bodhiruchi (508 A.D., he died in Lo-yang, China).

Bodhidharma (520 A.D., he came to China, where he died in 529 A.D.).

Yün-luan (Donran) (量 留) (502 A.D.-549 A.D.).

Tao-ch'o (Doshaku) (導綽) (died in 646 A.D., eleven years after the Nestorians arrived).

Shan-tao (Zendo) (善導) (died in 68I A.D., forty-six years after the Nestorians arrived).

Genshin (源 信) (94I-IOI7 A.D.).

Genku (源 空) (I I33-I 208 A.D.).

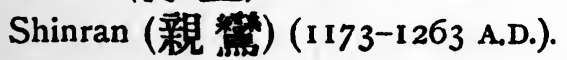


The chief authorities agree in saying that Shinran and his teacher Honen Shonin (Genku) improved upon the teachings of their predecessor Shan-tao, the Chinese Buddhist, who taught Salvation by faith in Amitabha and the doctrine of a Trinity - "when he preached, the Three Buddhas appeared in his breath!"

How Shan-tao got the idea of $A$ Vicarious Saviour of Unlimited Light or that of "Eternal Life" by Faith in Amitabha is the most important point. The mere fact that Shan-tao lived at the time when the Nestorian Mission flourished in China, and that both Buddhists and Nestorians were on sympathetic terms; that they often met at the Imperial Court of the $T$ 'ang Emperors; that about one hundred years after Shan-tao, Prajña from Kapisa was translating Buddhist scriptures with Adam, the Nestorian priest, in the ancient capital of China, are all sufficient proofs to convince any reasonable mind; whilst what the Rev. $Z$. Tachibana and Sir Aurel Stein have so lately discovered in the Khotan region shows that Amitabha Budfhism was very strong in the locality where Assyrian Christianity was strongest.

But if we trace back to the root of Shinran's teaching, it is summed up in a few words: "Man has no power to save himself." "Man cannot be saved by his own effort; it is by the grace and merit of Amitabha that man is saved: Nama Amitabha (We trust in Thee, $O$ Amitabha!) is all we need to say to be saved and no more!"

This is just the opposite to the Hinayana creed of Southern Buddhism, which declares: "No one can be saved by another; he must save himself; he must save himself without a vicarious Saviour."

We are told by certain Buddhists that the Buddhist idea of salvation by faith in Amitabha is the result of Evolution ; that the process was gradual and imperceptible. The doctrine of the Hinayana-"one must save oneself "-was changed in the course of many centuries into the doctrine, "one must 
save oneself by the merit of reciting the prayer-Nama Amitabha!" The salvation of man depended, not on the work, but on the merit of repeated prayer. This second stage, we are told, was again changed into the doctrine, "one can be saved, not by the work nor by the merit of repeating the prayer, but by the grace of Amitabha. We trust in Him, instead of trusting to our own effort, or merit, or offering the prayer."

We do not know how far this explanation given by a Buddhist can be confirmed by the canonical scriptures of Buddhism. But as to the Origin of the Amitabha doctrine, the following points are clear:

(I) It is quite foreign to Orthodox or Indian Buddhism -the Southern Church knows nothing whatever of it. Evidently the Theological Evolution did not take place in the South.

(2) In Northern Buddhism, i.e. the Mahayana school, the doctrine is found only in the Larger Sukhavati Vyuha, the Smaller Sukhavati Vyuha, and the Amitayur-dhyana Sutras. The first book was translated by Lokarakcha in 147 A.D., and An-shih-kao (Ashiki, Arsakes) in 148 A.D. But the translation now in use was made by Samghapala or Samghavarman (康佮 鎧) in 252 A.D. It is called Fo-shuo wu-liang-shou ching ("Bussetsu Muryojukyo") (佛說無量尋 經), i.e. "The Eternal-Life-Sûtra preached by Buddha."

In 402 A.D., Kumarajiva's translation appeared as Fo-shuo A-mi-t'o ching (Bussetsu Amida Kyo) (佛說阿霖 陀經), and in 650 A.D. Hsüan-tsang's (主贸) translation as Ch'êng-tsan ching-t'u Fo nieh-shou ching (Shosan Jodo Butsu Setsuju Kyo) (稳譛淨土佛攝受經).

According to Dr. Nanjio, "This suttra gives a history of the Tathagatha Amitabha, from the first spiritual impulses which led Him to the attainment of Buddhahood in remote Kalpas down to the present time when $\mathrm{He}$ dwells in the Western World called Sukhavati, where He receives all living 
beings from every quarter, helping them to turn away from Confusion and become enlightened."

The book is full of many strange personal names of disciples of Buddha.; and its allegorical tone renders it very difficult for the reader to grasp its true meaning. Yet it has the following words * about the birth of Gautama Buddha, which must sound very familiar to the Western Christian.

"Resigning His existence in the Heavenly Palace, the Spirit of God was incarnated in the womb of a mother."

" He cried out, "I shall be peerless in the world!"”

"When He was born, all the gods waited upon Him. All the angels adored Him."

" He had all Sciences and Arts at His fingers' end."

Again, about His temptation and victory over the Devils, it has the following words :

"Radiating the Great Luminous Light, He informed the Devil of the fulness of His time. Then came the Devil with all his kindred and tempted Him. His wisdom and power were more than theirs all combined, so that they were all conquered by Him."

Then as the Saviour of the world the following is said of Buddha :

" $\mathrm{He}$ is a true Friend to all that are heavily burdened before they ask for His help."

Again, about His glory:

"When He spake these words, His body became pure and $H$ is face transfigured as the Sun and His raiment as the pure Mirror."

About how to lead a Spiritual Life the book says :

" He said, "Why do ye not give up worldly cares and seek the moral before everything?' Ye have the eternal life and ye have the endless enjoyment of pleasure of life."

"If ye have a field, ye take too much thought of the field. If ye have a house, ye take too much thought of the house."

* See Appendix, No. III. and No. IV. 
"He that has one thing shall need for another."

"Why do ye not seek the eternal life in earnest? Why do ye not seek the Truth? Why do ye stand idle'?"

"If we sow good seed we shall reap good fruit. If we walk in the true Way we cannot but fulfil the true Way."

"Conquer ye evil with goodness ; not evil with evil."

"If ye recognize your old sins and do earnestly repent and sincerely desire to separate from them, ye can do so only" by asking Him for His help. Ask and ye shall be saved."

The second book was translated by Hsüan-tsang in 650 A.D. In this it is taught that if a man keeps in memory the name of Buddha Amitabha one day or seven days, the Buddha together with the Bodhisattvas will come and meet him at the moment of death so that he may be re-born in the Pure-land, Sukhavati (西方淨土).

About Salvation by Faith, this book has these sayings :

"O ye good men and women! If ye only have Faith, re-birth in the Pure-land, Sukhavati, shall be given to you!"

"If any one already began to ask Him in the past or is willing to ask Him in the present or shall ask Him in the future to grant the re-birth in the Pure-land of Amitabha, He will grant it to any one freely at the very moment of asking."

The third book was translated into Chinese in 442 A.D. by Kalayashas (畺良耶舍). In this book (as we are told by Dr. Nanjio) "Queen Vaidachi, wearied of this wicked world, is comforted by Sakyamuni, who teaches her how to be born in the Pure-land and instructs her in the three kinds of Goodness. These are : (I) worldly goodness-filial piety, loyalty, respect for parents, etc. ; (2) morality of that inward and unworldly kind which is the first foundation of the religious life; and (3) the goodness of practice, which includes the practical application to life of the four great truths and the six Paramitas or cardinal virtues. A good seed produces good fruit in abundance. If we sow the seed 
of the Three Goodnesses, we shall reap as a fruit the manifold bliss of the Pure-land."

The book says :

"Vaidachi said unto the Lord : 'Lord, by reason of what old sins must I suffer from the hand of my own wicked son? Lord, if Thou hast mercy upon me, preach Thy Salvation for my sake. I am tired of this wicked world of sins. I do earnestly repent of my sins! O Thou, the Sun of Buddha, shine forth Thy glory and show me the Way of Pure Life (i.e. redeemed life)'!"

"The Lord said unto Vaidachi 'Knowest thou that Amitabha is not far from thee ? Meditate thou with all thy heart and at all time upon Him '!"

"The Mind of Buddha is the mind of the great love and Mercy which freely saves the souls of all mankind."

"Amitabha radiates great shining Light from His own person. His glory shineth forth the Way (to walk in) for the believers in Him."

" $\mathrm{He}$ and all His Bodhisattvas welcome the believers at the Gate of Paradise giving them their hands!"

The relation of Amitabha to Christianity is too great a problem for us to discuss and is altogether beyond our present purpose. But it is clear that the Assyrian Christians were not opposed to this Amitabha doctrine, and that its development in China furnished a common meeting-ground and lever for them and their friendly collaborators, the Buddhish monks.

Chronologically speaking, we cannot escape the conclusion that Shan-tao must have been on sympathetic terms with the Nestorians in China. And so long as the Japanese Buddhist historians claim "The Transmission," or "Apostolic Succession " of Shinran Shonin through Shan-tao and Tao-ch'o they cannot deny that Shinran Shonin was, indirectly and unconsciously (it may be even to himself), related to the Assyrian Church of the Messiah in China. 
Kao-Tsung (650-683 A.D.), who was a great friend of Shan-tao, was the very Emperor who most helped the Assyrian Church in China! Our Inscription says :

"The great Emperor Kao-Tsung reverently succeeded his ancestors. Embellishing and completing the True Religion (檤宗) (this is the very name by which the Japanese sect of Shinran is known!). He caused a Luminous monastery to be built in every province and extended his favour to A-lo-pên, and raised him to be the Patron Saint and Spiritual Lord over the Empire. The Religion had free course throughout the Ten Provinces. The State enjoyed great peace, and a monastery was founded in every city, and family life flourished in the Luminous happiness."

Under these circumstances it is impossible to imagine that Shan-tao was ignorant of the Nestorian doctrines.

It was in the year I200 A.D. that Shinran Shonin was allowed by his teacher Genku (Honen Shonin) to marry. This was a new departure in Buddhism whether in China or in India. Even in the history of Buddhism in Japan it is unprecedented. But when we know that the Nestorian priests in the time of Shan-tao were canonically allowed to marry, it need not surprise us to see the spiritual descendants of Shan-tao in Japan some five hundred years later permitting marriage.

Although we have as yet no direct evidence to prove that the legitimatizing of a Buddhist priest's marriage was copied from the Nestorian example in China, we are convinced that Genku' (Honen Shonin)-Shinran's Master-did take a leaf out of the Nestorian book.

It was in the year 499 A.D. that the Nestorian bishops held a Synod at Seleucia-Ctesiphon and formally repudiated clerical celibacy. This decision might have been due to Persian influence, as celibacy was so repugnant to Persian prejudices. If this be so, then Persian influence would have been very powerful in the seventh and eighth centuries amongst. 
the Nestorians in China, so that it is not surprising that we should read in the Inscription: "Deacon Adam, the son of chorepiscopos Yesbuzid. Mar Yesbuzid, chorepiscopos of Kumdan, the Royal City, the son of the late priest Milis."

The Prime Minister Fujiwara Kanesane asked Genku to find a suitable young man who could set a good example to the world by showing that married life is no hindrance to salvation.

Genku (Honen Shonin) (who was evidently in favour of priestly marriage) having obtained his disciple's consent, recommended Shinran to the Prime Minister. Thus the marriage of priests was introduced into Japanese Buddhism at the end of the twelfth century.

If we compare Shinran with Luther in this respect, we see that whilst the Japanese reformer simply bore witness to the world that the religious life with a legitimate wife according to his own Buddhist faith is not impossible, the German reformer-monk protested his right to marry a nun against the Papal rule. One was a fighter but the other was not.

"A great licentiousness treads on the heels of a reformer. How many times in the history of the world has the Luther of the day had cause to lament the decay of piety in his own household! 'Doctor,' said his wife one day to Martin Luther, 'how is it that whilst subject to the Papacy, we prayed so often and with such fervour, whilst now we pray with the utmost coldness and very seldom ?"' This could not be said of Shinran!

We do not know how far these words of Emerson's hold good in the Reformation History of Japan. But one thing is certain, that "I pray not that Thou shouldest take them out of the world, but that Thou shouldest keep them from the evil," was Shinran's ideal as it was also the ideal of Luther. Hence both Buddhists and Christians may understand the words in the Nestorian Inscription : 
"They preserve their beards to show how their work lies without themselves; they shave their crowns to show that they have no private inward affections."

The beards remind them of their work of love and charity, whilst the shaven crown-the tonsure which is peculiar to the Mahayana and not found in the Hinayana Buddhism-reminds them that they are "not of the world." They were Nestorian clergy at heart, but as men more human than their fellows. "They do not differ from the laity in their outward appearance, whilst of greedy selfishness they have none."

Speaking Buddhistically, this is the Mahayana doctrine of Mahayana doctrines. It is of a piece with the principles of Ashvagosha and Nagarjuna. The paradox of the laypriest and the priest-laic was a part of the great principle which was realised in the legal marriage of the priest.

We have shown that the Nestorian Stone cannot be a Jesuit fabrication, as was once erroneously sup- Conclusion. posed. And if its genuineness be established then we can immediately appreciate its value.

It is really "the Speaking Stone!" and in it we recognize a similar value to that of the Moabite Stone, or the Rosetta Stone, or the Rock of Behistan on the Caravan High-road to the Far East-all of them witnesses in stone to the Truths of the Bible, or affording Keys whereby to interpret it.

By this Nestorian Stone we can at once explain why so many European elements are observable in the Chinese civilization of the Middle Ages. We can also trace, "fore and aft," so to speak, in Assyrian Christianity, the Vairochana Religion, the Amitabha Doctrine, the Feast of departed Souls, the eating of flesh, and the legal and canonical marriage of priests as well as the tonsure- "the Crown of Thorns " mentioned in the "Travels to the Western Heaven," a Chinese Buddhist allegory which exhibits strong Nestorian influence-all of which are most conspicuous elements in Japanese Buddhism, 
but quite contrary and entirely foreign to Southern Buddhism and to the greater part of the Mahayana School in High Asia. As for the Mahayana School in India of which we have spoken so often, we are told by good authorities that there is now no Mahayana in India as it was utterly destroyed by the Arabs and Brahmans over 1000 years ago, China and Japan being the only countries where this new Buddhism has attained its full growth.

If any one should ask what influence Nestorianism had on Chinese thought in general, we reply that it was the great change effected by the Nestorians on the ${ }_{t}$. Chinese idea of "Heaven," which after the seventh century, became gradually merged into that of a Personal God.

The theistic conception of the world was strongly and clearly expressed by the Confucian and Taoist scholars between 618 and 1277 A.D., which is commonly known as the T'ang and Sung period of Chinese literature. The most sceptical cannot deny that the best Chinese literature of these two dynasties is interpenetrated by the theistic conception of "Heaven." We cannot but observe that this remarkable change took place in the period following the arrival of the Nestorians. What Dr. Legge said fifty years ago in his translation of the Chinese classic "The Doctrine of the Mean": "In the meantime the Chinese idea was antagonistic to Christianity. By and by, when Christianity predominates in the New China, men will refer to it as a striking proof how their fathers by their wisdom knew neither God nor themselves," cannot by any means be said of the Chinese of the Nestorian period!

The Nestorian contribution to the development of a theistic or Personal God is indeed great and valuable. The Christian idea of a personal God could find no better tree on which to be grafted than Chinese thought, whose heritage of moral precepts (derived from Lao-tzŭ and Confucius) may be compared with that of the Hebrew and 
Christian Scriptures. We can point to no moral precept which was a Nestorian monopoly, or which was entirely new and unknown to the Chinese of the seventh, eighth, and ninth centuries A.D.

When the Nestorians came to China, the Chinese, for centuries past, had possessed a highly developed system of morals : "Rectification of the heart; Veracity of intention ; Cultivation of the whole individual person; the Right Management of the Family and good Order of the State; and so to attain the general Peace of the World." (The Chinese book, "The Great Learning.")

These constitute the end and aim of both the individual and the State-the individual had the ideal set before him to walk on the broad Highway of Charity, Justice, Order, Wisdom, and Fidelity ; and the mass of individuals composed the State. What could the Nestorian Teachers add to this ?

In mystical and profound doctrines or in simple and practical precepts, the Nestorians could not surpass either Taoists or Buddhists-especially in such doctrines as those of Dhyani, Abidharma, etc.

But, as some would say, we must acknowledge that the relation of Nestorianism in the seventh and eighth centuries to the civilization of the Chinese Empire somewhat resembles that of Christianity to the Græco-Roman civilization of the. Roman Empire in St. Paul's time !

The Nestorian missionaries stood before the Emperors of China as the Apostles stood before the Roman governors, whilst the Nestorians, like the Hebrew prophet, Daniel, and the monks of the West in the sub-apostolic age, were the trusted advisers of the Chinese and possibly Japanese Sovereigns!

But the chief merit of the Nestorians in China can by no means be ignored.

The true leaven never ceases to work. Weak and inperceptible as the Nestorian leaven was, it gradually but 
surely permeated the whole tone of Chinese literature during the T'ang and Sung Dynasties. And when all China was divided between Confucianists and Taoists on the one side and Buddhists on the other, the Nestorians turned the scale in favour of Chinese Ancestor-worship, and thus contributed to create what is known to-day as "Chinese Buddhism"and to confirm the belief in Amitabha-the Saviour who saves those who simply trust in and consecrate their whole being to Him.

That the Nestorians who were driven from Edessa to Persia, and thence to Central Asia, and finally to the Middle Kingdom-sometimes sheltered by Arabs and sometimes by Hindoos-should have performed this great work of leavening Chinese thought with Theistic conceptions, reminds us of that "Stone which the builders rejected but which became the chief Corner-stone!"

But should any one ask, "Why the Nestorian Church once so strong in China cannot now be discerned there?" we reply that we can find their remnants-partly in the Chin$\tan$ Chiao (金丹教), whose number amounts at present to ten millions, and partly among the twenty millions of Mohammedans in China.

As for the theological difficulties, we should like to emphasize that the most difficult thing for an intellectual Chinese to believe, is the "Resurrection of the Lord," which is as great a stumbling-block to them as it was to the Men of Athens in the days of the Apostle Paul (Acts xvii. 16). There is a curious sentence in Ssŭ-ma Kuang's "Mirror of History" under the seventh century (a few years after A-lopên's arrival in 635 A.D.), which runs thus :

"There came a priest from the Western Regions who was skilled in charms and magic: he could cause people to fall down dead, and then, after muttering an incantation over them, to come to life again" ( $T z \bar{u}$ chih tung chien, ch. 195, year 639 A.D.). 
（有詣自西域來. 善咒術. 能令人立死. 復

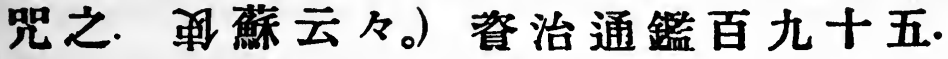
(唐太宗貞觀十三年紀)

Strange as this remark appears, it resembles the rumour we ourselves heard here in Japan some thirty or forty years ago, that "any Christian missionary could work miracles" (which is nothing but Magic); hence Christian missionaries were much dreaded by the mass of the Japanese people owing to a mistaken idea which had been handed down from father to son for generations ever since the great Persecution by the Shogun in I6I I A.D.

History repeats itself. What once happened in Athens, occurred again in China, six hundred years later; and the same thing is still taking place in our own Japan which inherited the civilization of Ch'ang-an! The difficult problems of the seventh and eighth centuries are the very same that the Japanese Church has to face and solve to-day.

But what lessons can we learn from the history of the Syriac Church in China? This depends on how we study this Inscription.

If we mention the failures of the Nestorian Mission in China, we should say first of all, that they did not raise up native workers. The foreign missionaries relied on themselves too much. We see hardly any native Chinese priests amongst the seventy-five names inscribed on the sides of the Nestorian Stone.*

And, secondly, they were cut off from the main stream of the Church after the tenth century; at least they were not

* It may be insisted-not without good reason-that it is impossible to distinguish natives and foreigners with any degree of certainty. But to any one all names mentioned in the Inscription would seem to be "foreigners" as the contexts show, whilst to the author almost all the names on the sides of the Stone secm not to be the native Chinese. Possibly Priest P'u-chi (促 only Chinese, though we have no clear evidence except that this name is unusual for a Syriac one. 
reinforced from the main body after the rise of Mohammedanism. China was too vast a country to be Christianized by a comparatively small Church which had no "MotherChurch" to back it or strengthen the Nestorian body in China. Thus the detached regiment of the Soldiers of Christ, not being in communication with the main body of the army, was finally cut off from it. And this is the position of the Nestorian remnant in China to-day!

Again, it appears to us that the missionaries relied too much upon Imperial favour. They died or were smothered under too much favour from principalities and powers as a State religion so often is. "Too much kindness," in this. case, "killed the cat!" A State Church is a national confession of God, and the nation which disowns or ignores God is doomed; but the State protection of religion is apt to lead to State corruption of religion too.

But we can perceive Nestorian influence in the books of the Mongol period. We can recognize their relics in the Chin$\tan$ Chiao and Mohammedans of China; in the Ancestorworship which they harmonized with the Feast of departed Souls; in the name of "The Vairochana-Religion"; in priestly marriage and meat-eating; in the "Salvation-by-faith-inAmitabha-Buddhism " and Eternal Life ; and in the theory of “God-in-man”(神人合一說) upheld by the Sung scholars.

Verily the Syriac Church did abundantly fulfil her mission in the Far East!

We have only to go back to the sources in Japan in order to "convince" the so-called "heathen" in our midst-whose ancestors actually heard the Christian verities so long ago! -to wake them up and make them understand that their ancestors were indeed Christians or (at least) possessed Christian truth under a different name. Yaso, Jesus,

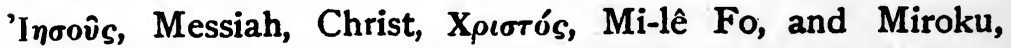
are all Names for the One Being, "One without a second," 
as the inscriptions on the Egyptian Pyramids declared five thousand years ago.

And should the attitude of foreign missionaries in China and Japan towards the "heathen " amongst whom they work be softened, even a little, and the remnant of the old Nestorian Christians be identified among the ten millions of the Chin-tan Chiao, or discovered among the twenty-ore millions of Mohammedans in China, then surely our study of the Inscription on the Venerable Stone-Tablet at Hsi-an-fu will not be in vain! 


\section{PART II.}

\section{THE TRANSLATION OF THE INSCRIPTION.}

A Monument commemorating the Propagation of The Ta-ch'in (I) Luminous Religion (2) in the Middle Kingdom (3).

[The figures correspond to the Number in the Notes, pp. 181-256.]

EULOGY on a Monument commemorating the propagation of the Luminous Religion in the Middle Kingdom, with a Preface to the same, composed by Ching-ching (4), a priest of the Ta-ch'in monastery (5) (in Syriac), Adam (4), priest and chorepiscopos, and papas (pope) of Zhinastan (6).

Behold! there is One who is true and firm, who, being Uncreated, is the Origin of the origins; who is ever Incomprehensible and Invisible, yet ever mysteriously existing to the last of the lasts ; who, holding the Secret Source of Origin, created all things, and who, bestowing (7) existence on all the Holy ones, is the only unoriginated Lord of the Universe, (9)-is not this our Aloha (8) the Triune, mysterious Person, the unbegotten and true Lord?

Dividing ( 10 ) the Cross, He determined the four cardinal points. Setting in motion the primordial spirit (wind), $\mathrm{He}$ produced the two (II) principles of Nature. The dark void was changed, and Heaven and Earth appeared. The sun and moon revolved, and day and night began. Having designed and fashioned all things, $\mathrm{He}$ then created the first man and bestowed on him an excellent disposition, superior to all others, and gave him to have dominion over the Ocean of created things. 


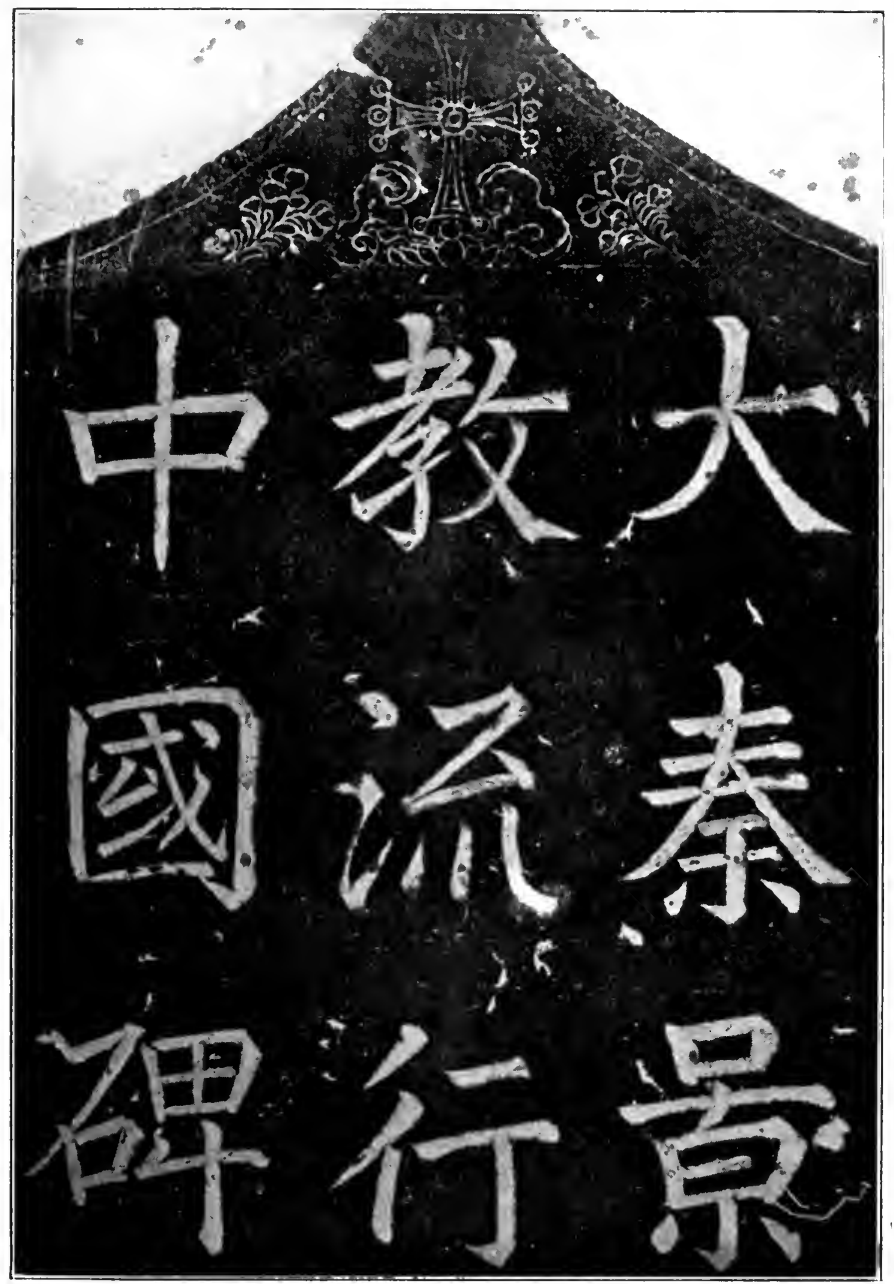

THE CROSS AND TITLE OF TIE "NESTORIAN MONUMENT."

(The title is translated in italics on p. 162, opposite.)

[To face $p$. I62. 

The original nature of Man was pure, and void of all selfishness, unstained and unostentatious, his mind was free from inordinate lust and passion. When, however, Satan (12) employed his evil devices on him, Man's pure and stainless (nature) was deteriorated ; the perfect attainment of goodness on the one hand, and the entire (13) exemption from wickedness on the other became alike impossible for him.

In consequence of this, three (14) hundred and sixty-five different forms (of error) arose in quick succession and left deep furrows behind. They strove to weave nets of the laws wherewith to ensnare the innocent. Some pointing to natural objects pretended that they were the right objects to worship ; others denied the reality of existence, and insisted on ignoring the duality; some sought to call down blessings (happiness or success) by means of prayers and sacrifices; others again boasted of their own goodness, and held their fellows in contempt. (Thus) the intellect and the thoughts of Men fell into hopeless confusion ; and their mind and affections began to toil incessantly; but all their travail was in vain. The heat of their distress became a scorching flame; and selfblinded, they increased the darkness still more; and losing their path for a long while they went astray and became unable to return home again.

Whereupon one Person (15) of our Trinity, the Messiah (16), who is the Luminous Lord of the Universe, veiling His true Majesty, appeared upon earth as a man. Angels proclaimed the Glad Tidings. A virgin gave birth to the Holy One in Ta-ch'in (17). A bright Star announced the blessed event. Persians saw the splendour and came forth with their tribute.

Fulfilling (18) the old Law as it was declared by the twenty-four Sages, $\mathrm{He}$ (the Messiah) taught how to rule both families and kingdoms according to His own great Plan. Establishing His New (19) Teaching of Non-assertion which operates silently through the Holy Spirit, another Person of the Trinity, $\mathrm{He}$ formed in man the capacity for well-doing 
through the Right Faith. Setting (20) up the standard of the eight cardinal virtues, He purged away the dust from human nature and perfected a true character. Widely (21) opening the Three Constant Gates, He brought Life to light and abolished Death. Hanging up the bright Sun, He swept away the abodes of darkness. All the evil devices of the devil were thereupon defeated and destroyed. He then took an oar in the Vessel(22) of Mercy and ascended to the Palace (23) of Light. Thereby all rational beings were conveyed across the Gulf. His mighty work being thus completed, $\mathrm{He}(24)$ returned at noon to His original position (in Heaven). The twenty-seven (25) standard works of His Sutras were preserved. The great means of Conversion (or leavening, i.e. transformation) were widely extended, and the sealed Gate of the Blessed Life was unlocked. His Law is to bathe with water and with the Spirit, and thus to cleanse from all vain delusions and to purify men until they regain the whiteness of their nature.

(His ministers) carry the Cross (26) with them as a Sign. They (27) travel about wherever the sun shines, and try to re-unite those that are beyond the pale (i.e. those that are lost). Striking (28) the wood, they proclaim the Glad Tidings (lit. joyful sounds) of Love and Charity. They (29) turn ceremoniously to the East, and hasten in the Path of Life and Glory. They (30) preserve the beard to show that they have outward works to do, whilst they shave the crown (tonsure) to remind themselves that they have no private selfish desires. They keep neither male nor female slaves. Putting all men on an equality, they make no distinction between the noble and the mean. They neither accumulate property nor wealth; but giving all they possess, they set a good example to others. They (3r) observe fasting in order that they may subdue "the knowledge" (which defiles the mind). They keep the vigil of silence and watchfulness so that they may observe " the Precepts." Seven (32) times 
a day they meet for worship and praise, and earnestly they offer prayers for the living as well as for the dead. Once (33) in seven days, they have "a sacrifice without the animal" (i.e. a bloodless sacrifice). Thus cleansing their hearts, they regain their purity. This (34) ever True and Unchanging $W a y$ is mysterious, and is almost impossible to name. But its meritorious operations are so brilliantly manifested that we make an effort and call it by the name of "The Luminous Religion."

But, at any rate (35), "The Way" would not have spread so widely had it not been for the Sage, and the Sage would not have been so great were it not for "The Way." Ever since the Sage and "The Way" were united together as the two halves of an indentured deed would agree, then the world became refined and enlightened.

When the accomplished Emperor T'ai-Tsung (36) (627-649 A.D.) began his magnificent career in glory and splendour over the (recently) established dynasty and ruled his people with intelligence, he proved himself to be a brilliant Sage.

And behold there was a highly virtuous man named A-lo-pên (37) in the Kingdom of Ta-ch'in (38). Auguring (of the Sage, i.e. Emperor) from the azure sky, he (39) decided to carry the true Sutras (of the True Way) with him, and observing the course of the winds, he made his way (to China) through difficulties and perils. Thus in the Ninth year of the period named Chêng-kuan (40) $(635$ A.D.) he arrived at Ch'ang-an. The Emperor despatched his Minister, Duke (4I) Fang Hsiuan-ling, with a guard of honour, to the western suburb to meet the visitor and conduct him to the Palace. The Sutras (42) (Scriptures) were translated in the Imperial Library. (His Majesty) investigated "The Way" in his own Forbidden apartments, and being deeply convinced of its correctness and truth, he gave special orders for its propagation. 
In the Twelfth year of the Chêng-kuan period (A.D. 638) in the Seventh month of Autumn, the following Imperial (43) Rescript was issued:-

"The Way" had not, at all times and in all places, the selfsame name; the Sage had not, at all times and in all places, the selfsame human body. (Heaven) caused a suitable religion to be instituted for every region and clime so that each one of the races of mankind might be saved. Bishop A-lo-pên of the Kingdom of $\mathrm{Ta}$-ch'in, bringing with him the Sutras and Images, has come from afar and presented them at our Capital. Having carefully examined the scope of his teaching, we find it to be mysteriously spiritual, and of silent operation. Having observed its principal and most essential points, we reached the conclusion that they cover all that is most important in life. Their language is free from perplexing expressions; their principles are so simple that they "remain as the fish would remain even after the net (of the language) were forgotten." This Teaching is helpful to all creatures and beneficial to all men. So let it have free course throughout the Empire."

Accordingly, the proper authorities built a Ta-ch'in (44) monastery in the I-ning (45) Ward in the Capital and twentyone (46) priests were ordained and attached to it. The virtue of the honoured (47) House of Chou had died away; the (rider on) (48) the black chariot had ascended to the west. But Virtue revived and was manifested again at the moment when the Great T'ang (Dynasty) began its rule, whilst the breezes of the Luminous (Religion) came eastward to fan it. Immediately afterwards, the proper officials were again ordered to take a faithful (49) portrait of the Emperor, and to have it copied on the walls of the monaster: The celestial beauty appeared in its variegated colours, and the dazzling splendour illuminated the Luminous "portals" (i.e. congregation): The sacred features (thus preserved) 
conferred great blessing (on the monastery), and illuminated the Church for evermore.

According (50) to the descriptive Records of the Western Lands and the historical works of the $\mathrm{Han}$ and Wei dynasties, the Kingdom of Ta-ch'in is bounded on the south by the Coral Sea (5I), and reaches on the north to the Mountain (52) of all Precious Things; on the west it looks toward the Gardens (53) of the Immortals and the Flowery Forests. On the east it lies open to the Long Winds (54) and the Weak Waters. The country produces asbestos cloth, the soul-restoring (55) incense, the bright-moon pearls, and night-shining gems. Robberies and thefts are unknown among the common people, whilst every man enjoys happiness and peace. None but the Luminous teachings prevail; none but virtuous rulers are raised to the sovereign power. The territory is of vast extent; and its refined laws and institutions, as well as accomplished manners and customs, are gloriously brilliant.

The great Emperor Kao-Tsung (56) (650-683 A.D.) succeeded most respectfully to his ancestors; and giving the True Religion the proper elegance and finish, he caused monasteries of the Luminous Religion to be founded in every (57) prefecture. Accordingly, he honoured A-lo-pên by conferring on him the office of the Great Patron and Spiritual Lord of the Empire. The Law (of the Luminous Religion) spread throughout the ten (58) provinces, and the Empire enjoyed great peace and concord. Monasteries were built in many cities, whilst every family enjoyed the great blessings (of Salvation).

During the period of Sineng-li (59) (698-699 A.D.), the Buddhists, taking advantage of these circumstances, exercised a great influence (over the Empress $\mathrm{Wu}$ ) and raised their voices (against the Luminous Religion) in the Eastern Chou, and at the end of the Hsien-t'ien (60) period (7 I2 A.D.) some inferior (6r) (Taoist) scholars ridiculed and derided it, 
slandering and speaking against it in the Western Hao. But there came the Head-priest (or Archdeacon) Lo-han (62), Bishop Chi-lieh and others, as well as Noblemen from the "Golden" region and the eminent priests who had forsaken all worldly interests. All these men co-operated in restoring the great fundamental principles and united together to re-bind the broken ties.

The Emperor Hsuian-Tsung (63) (712-755 A.D.), who was surnamed "the Perfection of the Way," ordered the Royal prince, the King of Ning. Kuo, and four other Royal princes to visit the blessed edifices (i.e. monastery) personally and to set up altars therein. Thus the "consecrated rafters" which had been temporarily bent, were once more straightened and strengthened, whilst the sacred foundation-stones which for a time had lost the right position were restored and perfected. In the early part of the period (64) T'ien-pao (742 A.D.), he gave orders to his general $\mathrm{KaO} \mathrm{Li}$-shih to carry the faithful portraits of the Five Emperors (65) and to have them placed securely in the monastery, and also to take the Imperial gift of one hundred pieces of silk with him, making the most courteous and reverent obeisance to the Imperial portraits. We feel as though "we (66) were in a position to hang on to the Imperial bow and sword, in case the beard of the Dragon should be out of reach." Although the solar horns (i.e. the August and Majestic Visages) shine forth with such dazzling brilliance, yet the gracious Imperial faces are so gentle that they may be gazed upon at a distance less than a foot.

In the third year of the same period (67) (744 A.D.) there was a priest named Chi-ho (68) in the Kingdom of Ta-ch'in. Observing the stars, he decided to engage in the work of Conversion (lit. transforming influence); and looking toward the sun (i.e. eastward), he came to pay court to the most honourable (the Emperor). The Imperial orders were given to the Head-priest (Archdeacon) Lo-han, priest $P^{\prime} u$-lun (69) 
and others, seven in all, to perform services to cultivate merit and virtue with this Bishop Chi-ho in the Hsing-ch'ing (70) Palace. Thereupon the monastery-names (7I), composed and written by the Emperor himself, began to appear on the monastery gates; and the front-tablets to bear the Dragonwriting (i.e. the Imperial hand-writing). The monastery was resorted to by (visitors) whose costumes resembled the shining feathers of the king-fisher bird whilst all (the buildings) shone forth with the splendour of the sun. The Imperial tablets hung high in the air and their radiance flamed as though vying with the sun. The gifts of Imperial favour are immense like the highest peak of the highest mountains in the South, and the flood of its rich benevolence is as deep as the depths of the Eastern sea.

There is nothing which "The Way" cannot effect through the Sage; and whatever it effects, it is right for us to define it as such in eulogy. There is nothing which the Sage cannot accomplish through "The Way"; and whatever He accomplishes, it is right we should proclaim it in writing (as the Sage's work).

The Emperor Su-Tsung (72) (756-762 A.D.), the Accomplished and Enlightened, rebuilt the monasteries of the Luminous (Religion) in Ling-wu, and four other counties. The great Good Spirit continued to assist him and the happy reign began anew. Great blessings were given (to him and his people) and the Imperial inheritance was made secure.

The Emperor Tai-Tsung (73) (763-779 A.D.), the Accomplished and Martial, greatly magnified the sacred Throne to which he succeeded. He observed the rule of non-assertion and walked in The Way of the Silent-operation. Every year when the (Emperor's) birthday (74) recurred, he bestowed celestial incense (on the priests) wherewith to report (to Heaven) the meritorious deeds accomplished by him. He distributed provisions from his own table and 
thereby gladdened the congregation of the Luminous Religion. Morever, Heaven blessed him with great blessings, and what he did cannot but reach far and wide. As the Sage is the Embodiment of the Original Way of Heaven, he completes' and nourishes the objects of his favours.

Our present Emperor (75) (who named the present period "Chien-chung" when he ascended the throne in 780 A.D.) is most sacred and august alike in the works of Peace and War. He developed the "Eight" (76) (objects) of Government, and degraded the unworthy whilst he promoted the deserving. He exhibited the "Nine divisions" of the grand scheme of Imperial government; and thus imparted new life and vigour to his own Illustrious Mission. Conversion (i.e. the transforming influence) leads (the people) to the understanding of the most mysterious Principles. There is nothing to hinder us from offering our thanksgiving prayers for him.

That those who are noble and exalted may behave humble-mindedly; that those who are devoted to the Perfect Stillness may also be sympathetic and lenient to others; and that they may thus seek, with boundless mercy, to relieve the sufferings of all, and with unselfish benevolence extend their helping hand to all mankind, these are our great plans for daily discipline and training, and gradual elevation of our life. Furthermore, in order that the winds and rains may come in their due season; that peace and tranquillity may prevail throughout the Empire; that all men may act reasonably; that all things may remain undefiled; that the living may flourish, and those who are dead (or dying) may have joy; that the words of the mouth may be in tune with their inmost thought as the echo follows the sound :-all these are the meritorious fruits of the power and operation of our Luminous Religion.

Our great Donor (77), the priest I-ssŭ who had the title of Kuang-lu-ta-fu(78) (i.e. one of the highest titles conferred on an officer), with the decoration-rank of the Gold (signet) and 
the Purple Robe, and who was also the Lieutenant-GovernorGeneral of the Northern Region, and the Assistant Over-Seer of the Examination Hall, was honoured with the purple clerical robe. He was mild in his nature and was naturally disposed to charity! Ever since he heard of "The Way," he endeavoured to practise it. From afar, from the "City (79) of the Royal Palace," he finally came to the Middle Kingdom, which in the advancement of learning now almost surpasses the Three (80) Dynasties, and enjoys the full development of knowledge and skill in all the Arts. First performing (8I) certain faithful services to (the one who dwells in) the "Red Court," he finally (82) inscribed his name in the Imperial book (i.e. thus pledging himself to be a loyal subject).

When the Duke Kuo Tzŭ-i (83), a Secretary of State and Viceroy of the Fên-yang Province, was first appointed to the charge of the military operations in the Northern Regions (750 A.D.) the Emperor Su-Tsung ordered him (I-ssŭ) to accompany the Duke to his command. Although so intimate with the Duke as to be admitted into his sleepingtent, yet so strictly and respectfully did he (I-ssŭ) behave that he made no difference between himself and others on the march. He proved himself to be "claw and tusk" to the Duke; and "ear and eye" to the Army.

He distributed all his salary as well as the gifts conferred on him, and did not accumulate wealth for himself and for his own family. He made offerings (to the monastery) of the Sphatika (84) (i.e. crystal) which had been granted to him by the Emperor himself, and dedicated to the monastery the gold-interwoven carpets which (despite his humble refusal) had been given to him by the Emperor's own favour. He also restored the old monasteries to their former condition, whilst he enlarged the worship-halls afresh. The corridors and walls were nobly ornamented and elegantly decorated; roofs and flying eaves with coloured tiles appeared like the five-coloured pheasant on the wing. 
Still further, ever since he took refuge in the Luminous Portals, he spent all his income in benevolent deeds. Every year he assembled the priests of the four (85) monasteries to have their reverent services and earnest offerings of prayers for fifty days. The hungry came to be fed; the naked came to be clothed; the sick were cured and restored to health; the dead were buried and made to rest in peace. Among the purest and most self-denying Dasa (86) (i.e. man-servants) of the Lord such excellent examples were never heard of; but we see this very man amongst the white-robed scholars of the Luminous Religion!

To the glory of God for all these eminent and meritorious events (above described), we engrave the following Eulogy. on this great Monument.

It is the true Lord who was Uncreated, And was ever profoundly firm and unchangeable. He created the Universe after His own plan, And raised the Earth and framed the Heaven. Dividing His God-head, He took human form And through Him, Salvation was made free to all. The Sun arising, the darkness was ended.

All these facts prove that $\mathrm{He}$ is the True Mystery.

The most Glorious and Accomplished Sovereign Surpassed all His predecessors in upholding "The Way." Taking Time at its flood, He so settled all disorders That Heaven was expanded and Earth widened. The brightest and most brilliant of all teachingsThe teaching of the Luminous ReligionTook root deep and firm in our Land of T'ang (87). With the translation of the Scriptures

And the building of convents,

We see the living and the dead all sailing in one Ship of Mercy ; 
All manner of blessings arose, and peace and plenty abounded.

Kao-Tsung succeeded to the Throne of his Fathers;

He re-built the edifices for Holy use.

Palaces of Peace and Concord stood resplendent far and near ;

The rays shining from them filled every part of the Empire. The truths of "The Way" were made clear to all men.

Setting up a new institution, he created "the Lord Spiritual ";

And every man enjoyed most blessed peace and joy, Whilst the land saw neither pain nor grief.

When Hsüan-Tsung commenced his glorious career, With might and main, he pursued the Way of Truth. The temple-names written by the Emperor shone forth ; The tablets of the celestial hand-writing reflected gloriously.

The Imperial Domain was embellished and studded with gems,

While the least and the remotest places attained the highest virtue.

All sorts of works undertaken by the people flourished throughout the land;

And each man enjoyed his own prosperity.

When Su-Tsung finally was restored to the throne, The Celestial Dignity guided the Imperial vehicle; At length the sacred Sun sent forth its crystal rays; Felicitous winds blew, and the Darkness fled;

Thus the precious Throne was made secure To the Imperial family of the great T'ang.

The causes of calamity took flight-never to return; Tumults were settled and men's passions subdued; The ideals of the Middle Kingdom were at last realized. 
Tai-Tsung was filial to his parents and just to all.

His virtues united with the great Plans of the Universe.

By his unselfish benevolence, he helped all mankind, Whilst the greatest blessings were realized in the abundance of wealth and prosperity.

By burning fragrant incense, he showed his gratitude; With benevolence he distributed his gifts to the people.

The Empire became so enlightened as though the glory of the Rising Sun in the Eastern Valley

And the full Moon in her secret cave were brought together as one.

When our present Emperor ascended the Throne, He took the reins of government and named the "Chien chung" (period).

He devoted himself to the cultivation of the Luminous Virtue.

His military sway quelled the tumults of the Dark Sea in the Four Quarters,

Whilst his peaceful rule of Enlightenment purified every part of the world.

As the light from a candle shines forth, so doth his glory penetrate the secrets of men.

As the mirror reflects all things, so nothing is hid from his observant eye.

The whole Universe gets life and light because of him. And even many of the rudest tribes outside the Empire take pattern by his government.

How vast and extensive is the True Way!

Yet how minute and mysterious it is.

Making a great effort to name it,

We declared it to be "Three-in-One"!

O Lord nothing is impossible for Thee!

Help Thy servants that they may preach !

Hereby we raise this noble Monument, And we praise Thee for Thy great blessings upon us ! 
Erected in the Second year of the Chien-chung period (781 A.D.) of the Great T'ang (Dynasty), the year Star being in Tso-o, on the seventh day of the First month (the day being), the great "Yao-sên-wên" (89) day; when the Spiritual Lord, the Priest Ning-shu (88) (i.e. "mercy and peace"), was entrusted with the care of the Luminous Communities of the East.

(In Syriac) In the day of our Father of Fathers, my Lord Hanan-isho, Catholicos, Patriarch.

(In Chinese) Written by Lü Hsiu-yen (90) AssistantSecretary of State, and Superintendent of the Civil Engineering Bureau of T'ai Chou (i.e. a department in Che-kiang).

(Below the Inscription, partly in Syriac and partly in* Chinese, are these notices) -

(In Syriac) In the year one thousand and ninety-two of the Greeks ( $1092-311=$ A.D. 781) my Lord Yesbuzid, priest and chor-episcopos of Kumdan, the Royal city, son of the departed Milis, priest from Balkh (94), a city of Tehuristan, erected this Monument, wherein is written the Law of Him, our Saviour, the Preaching of our forefathers to the Rulers of the Chinese.

(In Chinese) Priest Ling-pao (靈 賽).

(In Syriac) Adam, deacon, son of Yezdbuzid, chorepiscopos; Mar Sergius, priest and chor-episcopos.

(In Chinese) The Examiner and Collator at the erection of the Stone Tablet, priest Hsing-t'ung (行通).

(In Syriac) Sabr-isho, priest; Gabriel, priest and archdeacon, and the Head of the Church of Kumdan ( $9 \mathrm{r})$ and of Saragh.

(In Chinese) Assistant Examiner and Collator at the erection of the Stone Tablet, priest Yeh-li the Head-priest (93) of the monastery, who is honoured with the purple-coloured ecclesiastical vestment, and who is the Director (92) of the Imperial Bureau of Ceremonies, Music, and Sacrifices.

"This is the Syrrac name Hanan-isho, which means " Mercy of Jesus." 
帘

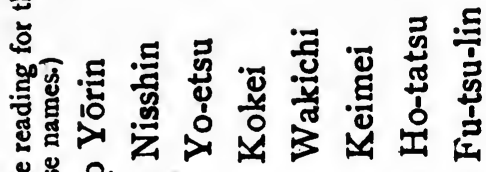

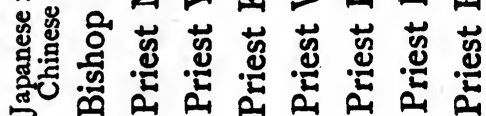

$\stackrel{\Xi}{E}$

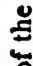

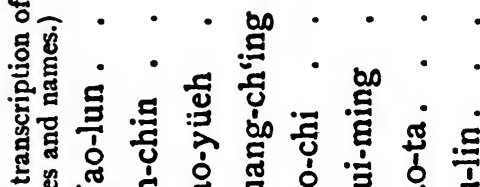

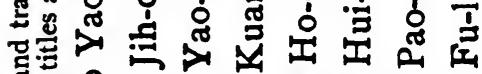

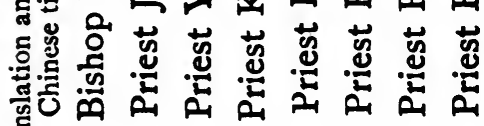
है

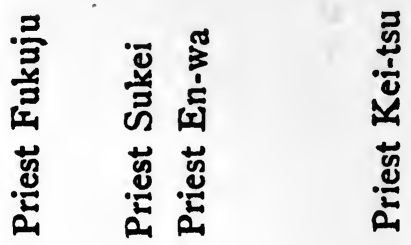

胥

y.

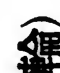

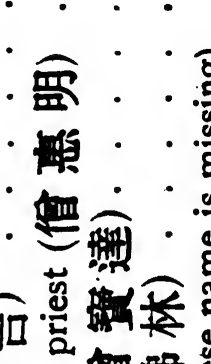

$\widehat{0}$

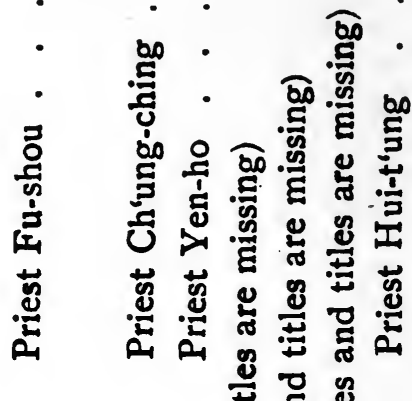

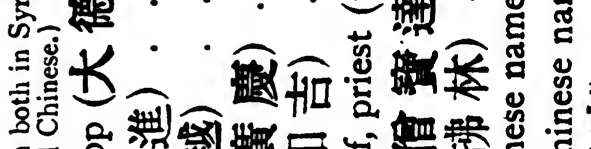

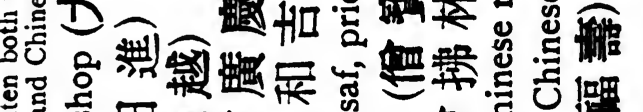

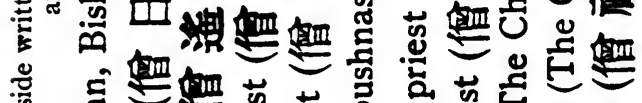

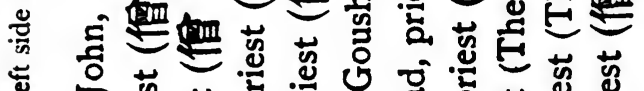

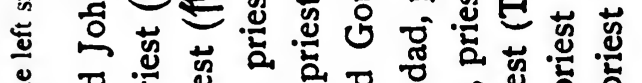

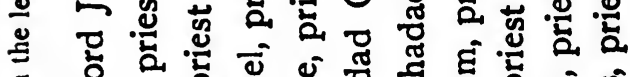

ま

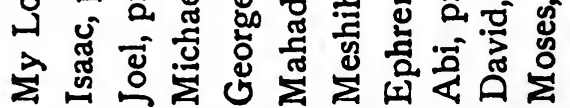

\section{型}

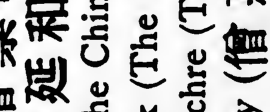

衈然

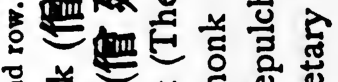

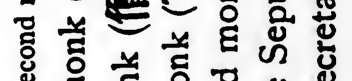

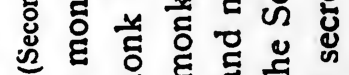
ए

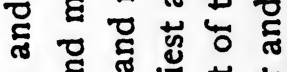

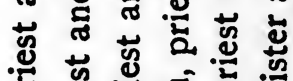

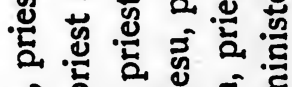

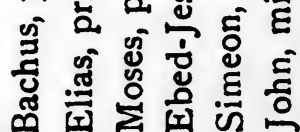


$\checkmark$

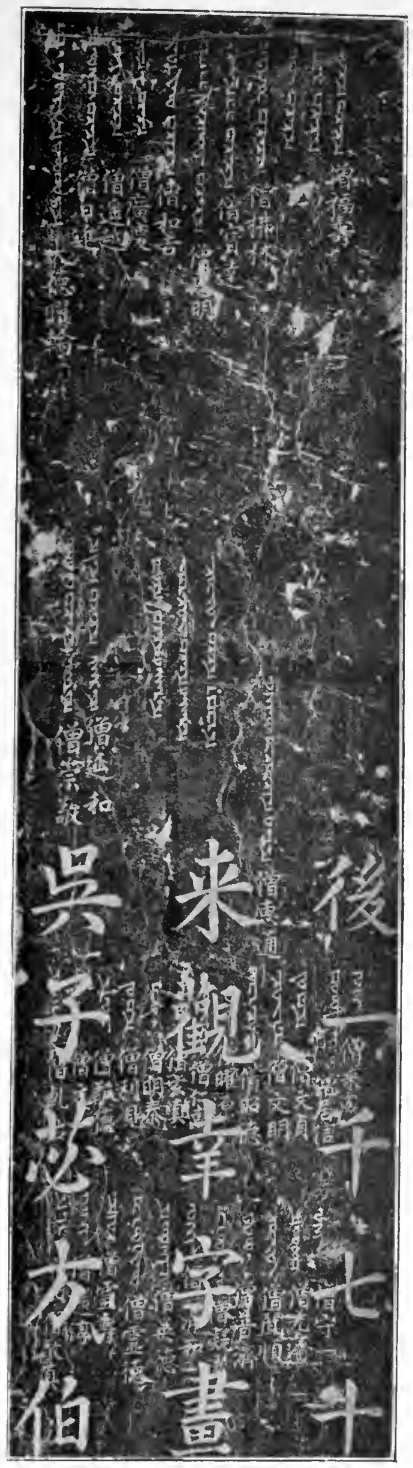

THE NAMES ON THE LEFT SIDE OF THE MONUMENT.

(Translated, pp. I76-ז78.)

[To face p. I 176 . 


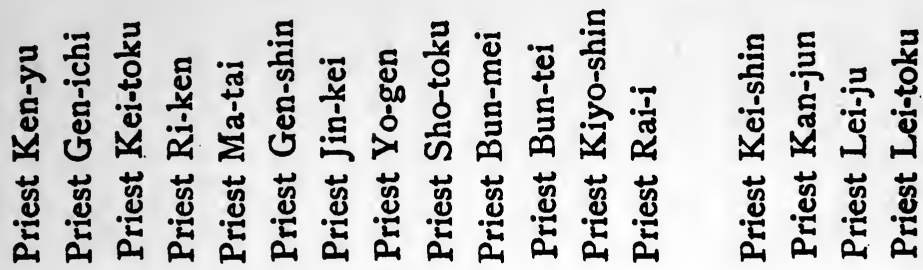

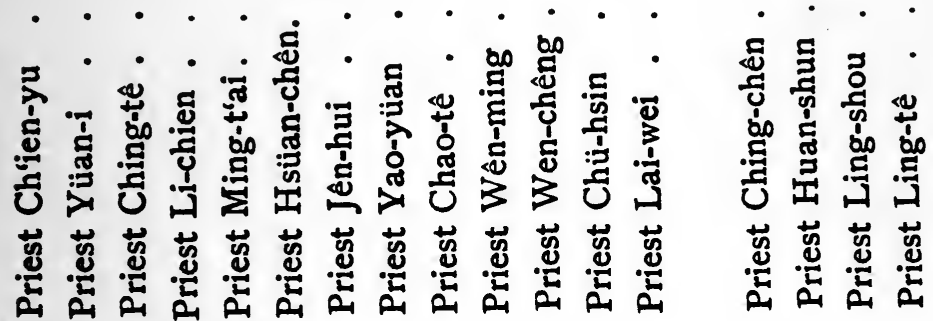

递

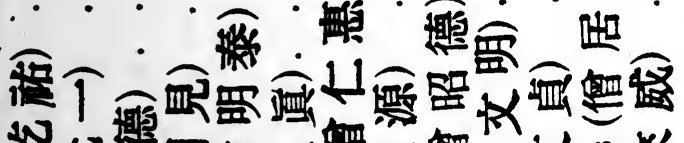
部

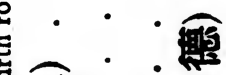

Inity

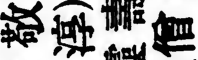

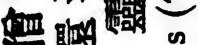
唄

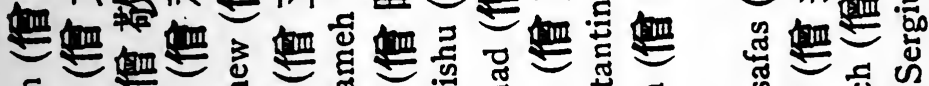

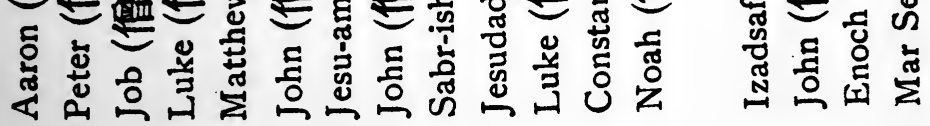


$\stackrel{8}{2}$

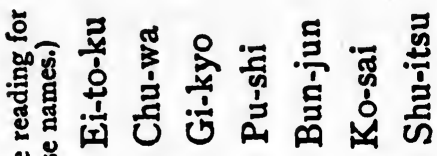

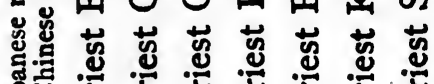

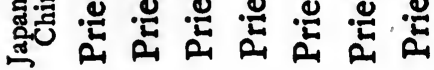
总

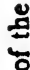

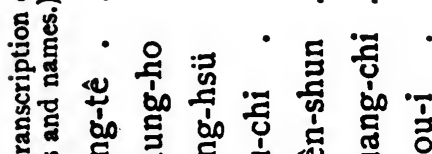

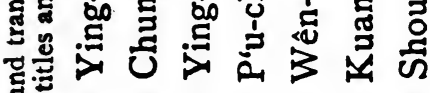

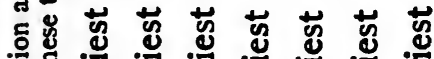

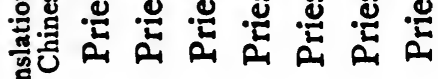
ह

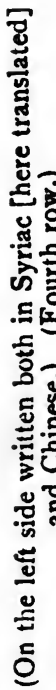

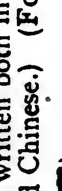

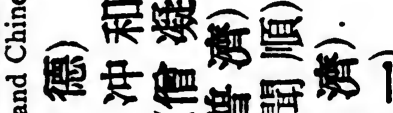

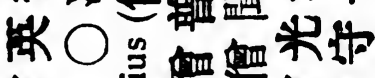

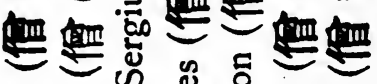

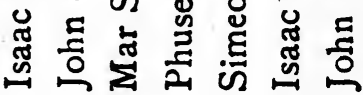

龸

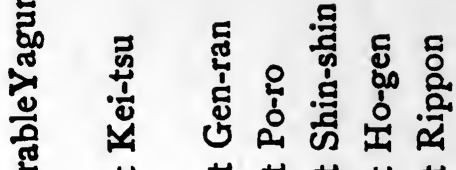

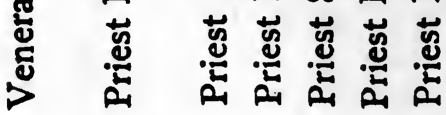

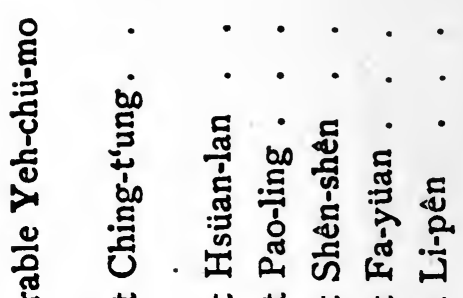

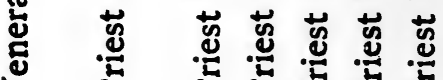

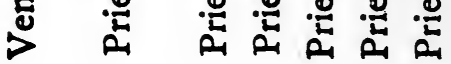

$\cdot \widehat{0} \cdot \overline{0}$

. ․ํㅇำ

. 若

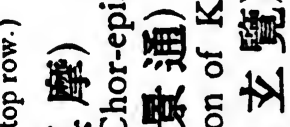

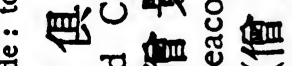

家要焉

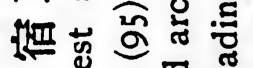

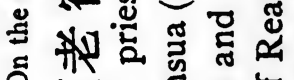
(H)

篮的

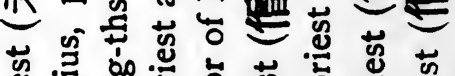

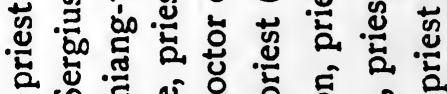

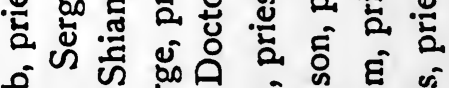

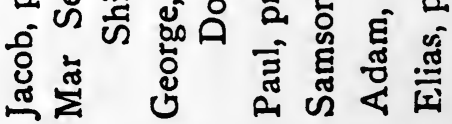




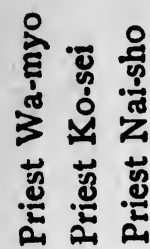

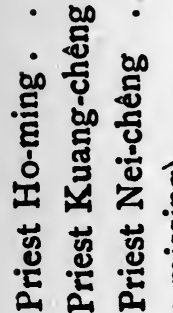
욜 용 惡

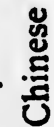

. . 䒿

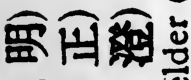
证。

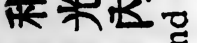

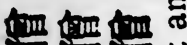
证

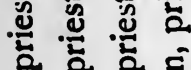

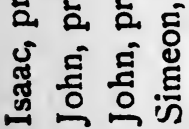

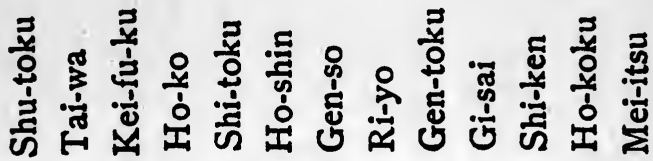

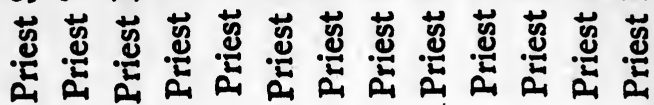

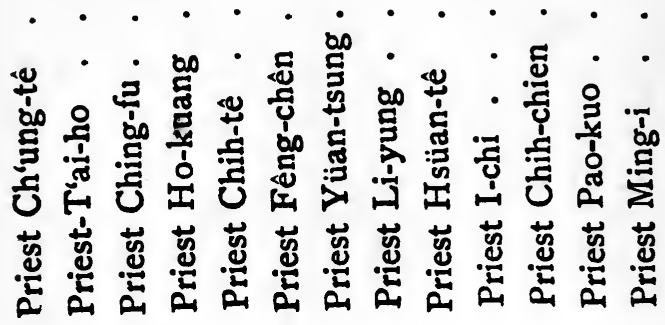




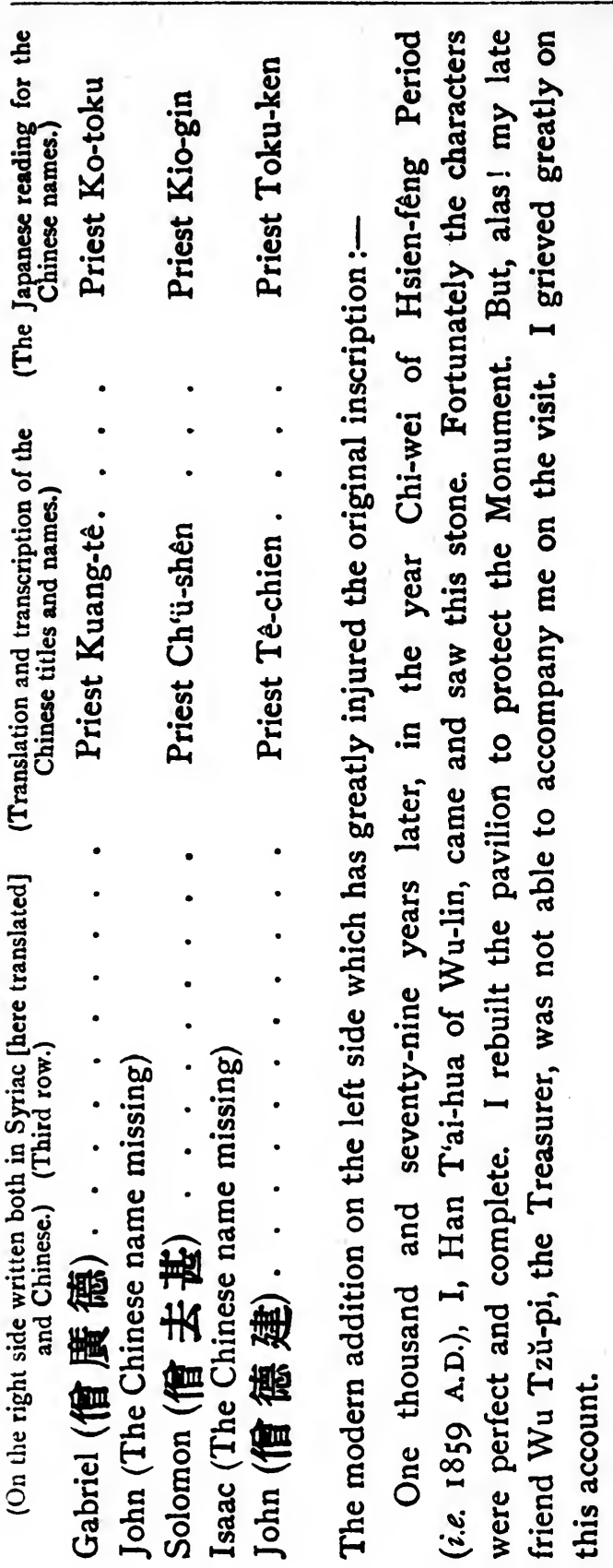




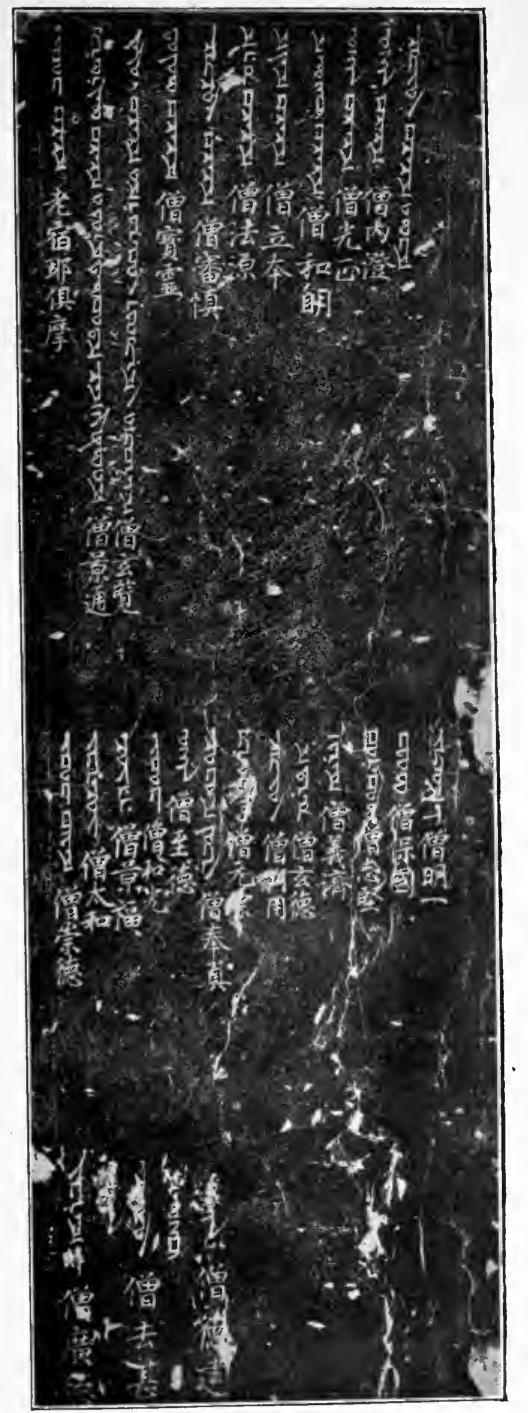

THE NAMES ON THE RIGHT SIDE OF THE MONUMENT.

(Translated, pp. I78--180.) 


$$
\text { - }
$$




\section{PART III.}

\section{NOTES ON THE TEXT.}

(1) Ta-ch'in.-Chinese authors used the words "Kingdom of Ta-ch'in" with different meanings at different times. But it must be a country near the Mediterranean Sea with a Patriarchal form of government as well as a Græco-Roman civilization, and must have included the land lying between Antioch and Alexandria. It was mentioned in the "Book of History" (史 記), written by Ssŭ-ma Ch'ien (司馬遷) in 95 B.C., as well as in the "History of Han" (漢 書), by Pan-ku (班 固), in 92 A.D. under the name of “ $L \mathrm{i}-\mathrm{k}^{\prime}$ 'an" (黎鞀). It is in the “History of After-Han” (後漢書), written by Fan Yeh (范 嘩), in 445 A.D., that we come across the name of Ta-ch'in (大秦) with the capital of “An-tu”(安都城) (i.e. Antioch).

Then again in the books written after the T'ang Dynasty (618-906 A.D.) the country is known as “Fu-lin" (茀菻國). The appearance of the name "Fu-lin" in Chinese history must have been very old, for one of the two first so-called Buddhist temples erected about A.D. 379 by the monk Jundo at Ping-yang, the old capital of Korea, was called "I-p'u-lan-ssŭ (伊尊藕寺), which may mean “The Ephraim Temple." But it is in the early part of the seventh century-between 605 and 616 A.D. when the famous Yang-Ti (焬 需), the Sui Emperor, tried to re-open intercourse with "Fu-lin" but in vain, that the name entered into the historical works. In the year 643 A.D., Po-to-li (波多力) (i.e. Patriarch) of the 
“ Kingdom of Fu-lin” (茀菻國) (i.e. Phrin or Ephraim) sent an Ambassador to the Chinese court.

We are quite safe in saying that "Li-k'an," "Ta-ch'in" and "Fu-lin" (Ephraim) are names connected with the lands where the Græco-Roman civilization was grafted on Hebrew thought and culture. But in our Nestorian Inscription, Syria, or at least that part of Palestine where Christ was born, was intended. This is obvious from the words: "A Virgin gave birth to the Holy One in Ta-ch'in."

In this expression, Ta-ch'in is used for Judæa. By it, at any rate, is meant that part of the Province of Syria where the Lord was born, whilst we know for certain that the "Ta-ch'in" of the Chinese Annals was a part of the great Roman Empire.

The following quotations from authors who have spent more time and energy than others in elucidating the subject may help the student to understand the "Fu-lin mystery" and its relation to "Ta-ch'in." The following are from the edition of the book "Chau Ju-kua" by Dr. Hirth and Rockhill (pp. 104, 105).

"The Ta-ts'in of the twelfth century, as represented in Chóu K'ü-feì's account, has all the characteristics of an ecclesiastical state. As in ancient times Ta-ts'in and Fu-lin may be looked upon as the representatives of the Christian world united under a spiritual chief, the Patriarch of Antioch, so the King of Ta-ts'in of the twelfth century must have been a patriarch, and, as is shown in a subsequent note, this king must have been the Nestorian patriarch of Baghdad, which city was indeed, at that time, the point of junction where all the great trade routes of Western Asia united. The words '[Ta-ts'in was] also called Li-kien,' added here by Chau, are taken from the Hóu Han-shu (後漢書), 88, and refer to the Ta-ts'in of ancient times. "Since the capital of Ta-ts'in is called An-tu (Antioch) in the Weï-shu (魏書), I02, the so-called king of Ta-ts'in may have to be identified with the Patriarch of Antioch, who was 
indeed considered the spiritual head of all the Christians in Asia, certainly before the schism in 498 A.D., when the adherents of Nestorius established their own church in Chaldra. According to the T'ang-shu (唐書), 198, the king of Fu-lin called Po-to-li (波多力), sent ambassadors to the Chinese court in 643 A.D. This name lends itself admirably as a transcription of the Syriac form for 'patriarch,' viz. batrik. In Chou K'ü-fei's account, as copied by Chau Ju-kua, the king of Ta-ts'in in the twelfth century is styled (號. i.e. he is addressed by the title of) Ma-lo-fu (麻囉弗. Canton dialect : Ma-lo-fat, probable old sound Ma-lo-pat, or Ma-lo-ba, since $f u$ (弗) may stand for bha in Sanskrit transcriptions, see Julien, Methode pour déchiffrer, 104, No. 309). This again is an excellent transcription for Mar Aba, one of the titles by which the Nestorian patriarch could be addressed. Mar is a title of honour given to learned devotees among the Syrian Christians, somewhat like our "Venerable" (Ducange, Glossarium, etc., ed. L. Favre, s.v. Mar). Aba means 'father.' Mar-Aba may thus be translated by 'Venerable Father.' Its Latin and Greek equivalent was Patricius. (Assemanni, "Bibl. Orient.," III. B. 92 : 'Quem enim Graeci Latinique Patricium vocant, is dicitur Syriace $A b a$, et praefixo Mar, seu Domini titulo, Mar-Aba.')

"In the Syriac portion of the Nestorian Inscription of Si-an-fu the patriarch Hannanjesus II, ${ }^{*}$ who died in 778 A.D. three years before the erection of the monument in 78I, is referred to under the title Abad Abahotha Hanan Isua Qatholiqa Patrirkis. This does not exclude the possibility of all the patriarchs mentioned in Chinese records up to the time of Chou $\mathrm{K}^{\prime} \mathrm{u}$-fei as kings of Ta-t'sin or Fu-lin being patriarchs of Antioch."

(2) Luminous-Religion. - The Chinese character for “Luminous” is “Ching” (景) and consists of two characters "jih" (日) and “ching” (京)-the former standing

\footnotetext{
* Compare this with our Introduction, p. 35.
} 
for "sun" whilst the latter is a phonetic. The Sun-great means " Luminous."

The writer of the Inscription-not, be it noted, Chingching, its composer, but the Chinaman Lü Hsiu-yen, employed or rather invented a different form of the character "Ching," (viz. (暴) instead of (景) the normal form found in the authorised Dictionary).

Why Lü Hsiu-yen used a new form for this and other characters throughout the Inscription has been much discussed by European critics. For instance, Dr. Legge says in his note :

"It has been made an objection to the genuineness of the monument that the form of the characters and style of the composition are so much akin to the writing and style of the present day. But the same objection may be made to other inscriptions of the same date, and even of dynasties older than the T'ang. No one familiar with the character and literature of the country would be likely to make it. Still there are some of the characters of an unisual form, though rarely unexampled. To two or three, not previously pointed out, attention will be found drawn in the present edition of the Chinese Text. I wish here to notice the character translated 'Illustrious,' and which everywhere in the monument appears as (景) instead of (景). There is no doubt that they are two forms of the same character, but I have nowhere found their difference of form remarked upon, and it has escaped the observation of all the lexicographers, Chinese as well as foreign. The second form is the correct one; the ' $\mathrm{jih}$ ' (日), or symbol of meaning is what it should be, and so is the 'ching' (京) or phonetic symbol. The writer of this Inscription uses (京) for (京) throughout, at which I am not surprised. How he should change the 'jih' (日) in the top of the character into ' $k$ 'ou' (口) surprises and perplexes me." (Dr. Legge, The Nestorian Monument, p. 3.)

Dr. Legge was perfectly correct when he remarked 
that he had nowhere found the difference of these forms commented upon, and that it has escaped the observation of all the lexicographers, Chinese as well as foreign, but the reason is not far to seek ; and if the lexicographers failed to notice the point, it may be due to the fact that almost all the native scholars fully understand the reason of the difference.

Anyone who has especially studied "the Stone and Metal Writings" is familiar with what is traditionally called "One-stroke-freedom of a Calligrapher." That is to say, a calligrapher enjoys the great privilege of changing the form of a certain ideograph with impunity to suit his own calligraphical taste so long as the original number of stroke is observed, and in certain cases he may add or take away a stroke from the original and orthodox numbers of strokes to show his skill, so that forms found in the Dictionary may differ from those that are found on the "stone or metal."

For example, the character standing for "pên" (本) meaning "root" or "origin," is to be-written thus (本), but calligraphers prefer to use their own form (奇) rather than that given in the Dictionary (本), because both the characters consist of five strokes, whilst in our Inscription the form of (提 k'ou) was used instead of (樞 $\mathrm{ch}^{\prime} \mathrm{u}$ ). So when Dr. Legge charged Dr. Bridgman with misreading this very ideograph, saying "Bridgman misreads (摳 k'ou) in it, as if it were (樞 ch'u) 'a pivot,' ' an axis," " he was entirely wrong, and Bridgman was perfectly correct in reading (揭) in the Inscription as (樞).

Not being aware of this calligraphical rule Dr. Legge translated “hsüan" (立) with “k'ou” (揂), which gives by no means a suitable meaning. On the other hand, “hsüan” (立) with “ch'u” (樞), meaning “mysterious source," is an established phrase which is frequently used in philosophical writings.

(3) The Middle Kingdom, "Chung Kuo," is a very old name for China. It dates from the establishment of the 
Chou Dynasty, about B.C. 1122 when the Imperial territory was so named from its own special position in Honan. It was surrounded by all the others and was really in the middle of all states. As the empire grew the name was retained, and thus the popular belief that China is actually situated in the centre of the earth was strengthened. Chung kuo jên, or "men of the Middle Kingdom," denotes the Chinese. (See p. 4, Vol. I., "The Middle Kingdom," by Dr. Williams.)

(4) Ching-ching (King-tsing). - This is the Chinese name for Adam, the Persian priest. The two Chinese characters used to represent it are very suitable ones: "Ching" (which the Southern Chinese pronounce "King") stands for "Luminous," whilst the second "Ching" (which, again, is "Tsing" in the south, stands for "pure" or "purified." The whole meaning would be "one purified by the Luminous Religion."

That this Adam laboured with Prajña, the Kashmir monk, in translating the Sat-paramita-sutra (see Introduction, pp. 7I-74) shows that he must have studied Buddhism, whilst this Inscription composed by him shows how thoroughly versed he was in Chinese Art and Literature. His death must have occurred some time between 785-823 A.D. He was associated with Prajña (who first reached Hsi-an-fu in 782 A.D.) in translating a Buddhist suttra some time between 785-805 A.D., as is proved from the Chinese books ; whilst the fact that a Metropolitan for China was consecrated by Mar Timothy, Catholicos and Patriarch some time between 782-824 A.D., is also proved from "The Book of Governors" by Thomas, Bishop of Marga, 840 A.D.; see Dr. Budge's translation where, on p. 448 , Vol. II., we read :

"Mar Eliya, whose history we are about to write, was elected Bishop of Mukan, David was elected to be Metropolitan of Beth Sinaye (i.e. China)-now I have learned concerning this man from the Epistles of Mar Timothy." 
It is our firm belief that this David was elected to be Metropolitan of China in succession to Ching-ching, Adam, whose title was "Papas of Zhinastan"-in other words "Metropolitan of China." Hence his death must have occurred during the reign of the Catholicos Mar Timothy.

(5) Monastery (寺) Temples or monasteries which enjoy the title of "Ssŭ" (寺), were limited to those supported by the Government. The names of “Aranyakah" (阿蘭若) or “Chao-t'i” (招提) were used for the Buddhist temples unsupported by the Government. Although the Nestorian Churches were supported by the Government and some of the Emperors and high officials favoured the Syrian Christians in China, the question how far the Chinese as a people were Nestorians presents itself.

(6) Papas of Zhinastan.- “Chên-tan” (震丹) are the Chinese characters used to represent China in the Hindu phonetisation ever since the time of the Ch'in Dynasty (B.C. 349-202) whose capital was at Hsi-an. "Papas of Zhinastan" means the Metropolitan of China, an office which was held by Bishop David early in the ninth century.

But how could a Chor-episcopos be also Papas or Metropolitan? We think Père Havret was correct in 'suggesting the "Papas," which denotes the office of the visitor, might have been used of the Metropolitan, as well as of lesser officers of the Church.

(7) Bestowing existence on all the Holy Ones (miao-chungshêng) (妙衆聖) lit. "mysteriously giving existence to multitudinous sages."-The phrase is doubtless borrowed from "I-ching, the Book of Changes." The Chinese "shêng" (聖) may mean more than "Sage" or "Holy man." Only an omniscient being was called "shêng," so we should prefer to render "chung-shêng," the expression before us, "all the Gods" instead of "Holy ones," were it in an ordinary Chinese composition.

Of course "shêng" has more than one meaning. It may 
mean sovereign or "Lord" in the secular as well as in the spiritual sense of the word. But that "shêng" in this place means "sage" or "Holy one," is beyond dispute.

(8) A-lo-hê (阿羅訶). - This is no doubt the Chinese phonetisation of the Syriac term for Eloh, God, and is equivalent to the Hebrew (plural) "Elohim," although the three Chinese characters used here are exactly the same as those which the Buddhist translator Kalayashas employed to represent "Arhat," the fruit of Buddha. See the Chinese translation of the Amitayur dhyana Satra (佛説觀無量帮經), by Kalayashas in 442 A.D., quoted on the page 133 of this book.

(9) Lord of the Universe.- "The Lord of the Universe," or "Highly Honoured by the Universe" is an epithet of Buddha. Here Ching-ching, Adam, used the same epithet in a Christian sense.

(10) Dividing the Cross.-More literally, "fixing the ideograph Ten," or "dissecting the ten-ideograph." The Chinese character "ten" consists of two strokes, one vertical and the other horizontal. The vertical stroke stands for the North to South, whilst the horizontal stroke stands for the East and West. So "dividing the ideograph Ten" actually means "determining the four cardinal points" or quarters, as in the expression which follows this.

This kind of phrasing, called "Introductory wording," is commonly used both in Chinese and Japanese composition ; and it is not necessary to suppose that by it the author of the Inscription meant the "Cross," a Christian symbol, as in paragraph seven.

(II) Two Principles of Nature.-By this what the Chinese call "twofold ether" was meant, Yin (陰) means the shadow or Darkness and Yang (淂) the Light or Brightness. The Spirit of Darkness and the Spirit of Light are indicated by the expression, which is borrowed from Chinese cosmogony -especially that of Taoism, which, it is possible, may have 
been derived from the Persian dualism, since Chinese dualism, like that of Persia, explains almost everything by the Two Spirits of Yin and Yang.

(12) Satan.-A Chinese phonetisation of the Syriac corresponding to the Hebrew word.

(13) The entire exemption from Wickedness.-This may not be the literal translation; but judging from the context, the sense of the Chinese text must be so rendered. Compare the following varieties of translation :

(Abbé Huc) "But Sathan propagated lies, and stained by his malice that which had been pure and holy: He proclaimed, as a truth, the equality of greatness, and upset all ideas."

(Wylie) "Man, acting out the original principles of his nature, was pure and unostentatious; his unsullied and expansive mind was free from the least inordinate desire: until Satan introduced the seeds of falsehood, to deteriorate his purity of principle; the opening thus commenced in his virtue gradually enlarged, and by this crevice in his nature was obscured and rendered vicious.

(Dr. Legge) "Man's perfect original nature was void of all ambitious pre-occupation; his unstained and capacious mind was free from all inordinate desire. When, however, Satan employed his evil devices, a glamour was thrown over that pure and fine (nature). A breach wide and great was made in its judgments of what was right, and it was drawn, as through an opening into the gulph of (Satan's) perversities."

(A. C. Moule) "It came to pass that Satan, the propagator of falsehood, borrowing the adornment of the pure spirit, disturbed the great (moral) equilibrium in (men's) goodness by the introduction of the likeness of confusion (which was) in his own wickedness."

(14) 365 different forms of errors. - The Chinese character “chung" (種) means "species" or "form." But why 365 ? The 
number corresponds with that of the days in an ordinary year. We may render the phrase: "different forms of errors which daily arise." " 365 " may mean "daily" or "innumerable." So it is not necessary to suppose that the "form" of error means only the " sect " or " doctrine." The meaning of the word "chung" (種) is far wider and much more general than that of "sect" or "doctrine." Although Mr. Yang (㛫策铥), the Chinese author on the Inscription, suggested in his book (景教碑文都事攻正) that the word "chung " means " sect" or " doctrine," the context "strove in weaving snares of the law," does not confirm his view.

(15) One Person of our Trinity.-Lit. "Three-one-dividedBody," "Messiah, who is the Luminous Lord of the Universe." The words "Three-one-divided-Body" being in apposition to the word, Messiah, we so translate them, although by so doing we stray from the beaten track.

Mr. Alexander Wylie rendered this expression, "Thereupon, our Tri-une being divided in Nature" ; whilst Dr. Legge translated it, "Hereupon our Tri-une (Eloah) divided His Godhead and The Illustrious and adorable Messiah," etc. ; and Mr. A. C. Moule rendered it, "Thereupon our Three in One divided Himself." ("Journal of the North-China Branch of the Royal Asiatic Society," Vol. XLI, 19ro, Shanghai.) We think that "fên-shên"（分身）ought here to be treated as a noun in an apposition to the word "Tri-une," and ought to be translated "One person" instead of "He divided Himself," as was shown by MM. Chavannes and Pelliot in Un Traite Manicheen, etc., 1912, p. 17. But compare p. 122 above on the IAmitabha Doctrine, which is identical with that of the stone.

Theophilus, bishop of Antioch, who flourished in the second century, was the first who used the word "Trinity" to express the three Sacred Persons in the Godhead, and the doctrine it expresses has been generally received amongst Christians" (Hulme's "Symbolism in Christian Art," p. 3I). 
(16) Mi-shi-ho.-This is, beyond all dispute, the Chinese phonetisation of the Syriac name of the Messiah. "Mshikha" is etymologically identical with the Hebrew "Messiah," but to the Assyrian Christians it stood and stands for more than the Messiah-king of Prophecy, i.e. for the Union of the Two Natures, "the God-man." (See "The Assyrian Church," pp. 288-9, by the Rev. W. A. Wigram, D.D., S.P.C.K.)

(17) Ta-ch'in.-Here Ta-ch'in is used for Judea or that part of the Roman Province of Syria where the Lord Jesus Christ was born.

(18) Fulfilling the old laws-by twenty-four sages. -The writer most probably meant by this the twenty-four writers of the Old Testament.

Some suggest that, in the original, the Chinese character "man" is accidentally omitted after the words "twentyfour shêng." Mr. Moule says : "In the original a word (?人 or 史) is here accidentally omitted. To Havret's proof of this we may add that the omission occurs at the end of a column-a most likely place, and that the last column of the Inscription is short by one word. Besides this slip in the writing there are at least two mistakes in the engraving."

We consider that the character was intentionally avoided, as its addition would spoil the composition. The apparent slip is by no means one, whilst what some declare to be "mistaken forms of the Chinese characters," are in reality neither mistakes of the writer nor of the engraver! See Note 2 above in connection with our explanation of the character representing "Luminous."

Besides, any well-educated Chinese or Japanese would at once understand from the context that the word "shêng" (聖) here stands for "sage" without being followed by the character "jên"(人) ("man" or "men"). To add the character "jên" after "shêng," would be as the Chinese proverb says, "adding feet to the centipede." 
(19) His new teaching of non-assertion.-Non-assertion or non-action is practically the same. This phrase was adopted from Taoism. Compare the Text with the following quotations from the Second Chapter of "The Tao-te-ching" (老子道德經) by Lao-tzŭ :

"When in the world all understand beauty to be beauty, then only ugliness appears. When all understand goodness to be goodness, then only badness appears ... therefore the holy man (sage) abides by non-assertion in his affairs and conveys his instruction by silence. When the ten thousand things arise, verily, he refuses them not. He quickens, but owns not. He works, but claims not. Merit he accomplishes but he doth not dwell on it.

"Since he doth not dwell on it, It will never leave him."

Alexander Pope must have been "an unknown Taoist" in Christian England when he judiciously observed in his "Essay on Man :"

"Men must be taught as if 'twere taught them not, And things unknown proposed as things forgot."

The author of the Nestorian Inscription used a Taoist phrase here as elsewhere, but added his own explanatory words, "which operates silently through the Holy Spirit," and thus Christianised the whole expression. The seventh century Assyrian Christians in China resembled the modern Quakers or Quietists in their teaching.

(20) Setting'up the standard of the eight cardinal virtues ... the dusts from nature, etc. Lit. "fixing the standard of the Eight Boundaries."-This is one of the most difficult sentences in the Inscription. Compare the following translations :

(Abbé Huc) "He signified to the world the eight 
commandments, and purged humanity from its pollutions, by opening the door to the three virtues."

(Wylie) "He fixed the extent of the eight boundaries, thus completing the Truth freeing it from dross. He opened the Gate of the Three Constant Principles, introducing life and destroying death."

(Legge) " He defined the measure of eight (moral) conditions, purging away the dust (of defilement) and perfecting the truth (in men).

(Moule) " He laid down the rule of the eight conditions. cleansing from the defilement of sense and making (men) saints."

What is meant by "eight" cardinal virtues? Mr. Yang (楊策 錂), a Christian Chinese and the author of a book on the Inscription, suggested that "Eight Beatitudes" was meant by "the Eight cardinal virtues," whilst others have suggested that it was the Eight Orders of the Assyrian Church.

We are inclined to believe that the phrase was borrowed from Buddhism. In one of the Gârbha Satras (佛説胞䏩經) we read of “Eight precepts." It says :

"Eight Precepts are truly what makes a Buddha of man" (入關热戒是諸佛父母). And these Eight precepts are :

(I) Kill no living being.

(2) Abstain from theft and robbery.

(3) Abstain from adultery.

(4) Abstain from lying.

(5) Abstain from wine.

(6) Do not sit on a high, broad, or large couch.

(7) Do not adorn thyself with wreaths of fragrant flowers, nor anoint thy body with perfume.

(8) Do not take part in singing or dancing, in musical or theatrical performances, neither look on nor listen to these things. 
Again, what is called the "eight rules of conduct" (or "marga" in Sanskrit) are as follows :

(I) Correct view, or ability to discern the Truth.

(2) Correct thinking, i.e. the mind free from wicked thought.

(3) Correct speech, or ability to avoid both nonsense and error in speaking.

(4) Correct profession-mendicancy, the vow of Poverty.

(5) Correct and suitable Virya or incessant practice of Asceticism.

(6) Correct Samadhi or mental coma.

(7) Correct memory or recollection of the Law.

(8) Correct life or strict observation of Purity.

This Gârbha Sutra was translated into Chinese by three different men-Dharmarakcha (A.D. 303), Kumaradjiva (A.D. 384-427) and Bodhirutchi (A.D. 684-727). So that the phrases must have been very familiar to Chinese Buddhists when this Inscription was written in the latter part of the eighth century.

It is not surprising that he who afterwards co-operated in translating the Satparamita Satra with Prajña, the Kashmir monk, should use these Buddhist terms and phrases.

Moreover, the expression in the context: "He purged away the dust" is borrowed from Buddhism. We are certain that "dust" here is the Sanskrit "Guna," which may well be translated "sensation," or "the objects of sensation" or finally "the organs of sensation" eyes, ears, tongue, body, and mind. The purification of these sense-organs is implied by the expression, "He purged away the dust." So we are justified in saying that the term "Eight cardinal virtues" was borrowed from Buddhism.

(21) Widely opening the three constant Gates.-The three graces of Faith, Hope, and Love have been suggested by Mr. Yang, Dr. Legge and others.

But we think that Ching-ching, Adam, the author of the 
Inscription here again adopted a Buddhist expression. Judging from the fact that "three Gates" must be the literal translation of the Sanskrit words, "Trividha Dvara," we think that purity of body, speech, and thought as the result of "purging the dust" from the human nature was implied by "widely opening the three constant Gates"the three Gates being the gates of sensations-eye, ear, and nose. John Bunyan in his allegory of the Holy War similarly uses the expressions "Eye-gate," "Ear-gate," when describing "the Siege of Man-Soul."

(22) He then took an oar in the Vessel of Mercy.-This expression is decidedly Buddhistic. Kuan-yin or Avalokiteshvara, who is the Saviour of the faithful, is generally represented with a ship on her back owing to the commonly accepted tradition that Kuan-yin saves people from shipwreck. One may understand by this that Kuan-yin rescues us from the shipwreck of life. This boat-shaped aureole is known in Japanese as "fünazoko." So we may understand by the phrase that the author desired to express the truth of Jesus the Messiah being the Pilot of life and death, as in one of Lord Tennyson's most beautiful poems "Crossing the bar." (See p. 66, supra.)

(23) The Palace of Light.-This means either Paradise or the High Heaven, the Empyrean where God dwells. The beautiful "New Jerusalem" described in the twenty-first chapter of the Book of Revelation is no other than this "Palace of Light" according to our common-sense reading, or Gokuraku-zodo, the Pure Land of Japanese Faith and Hope.

(24) He returned to His original position in Heaven. - Lit. "He ascended to the true (nature)." That the Ascension of our Lord was meant here is quite clear. The idea was neither new nor strange to the Chinese of the Middle Ages since Lao-tzŭ, the old philosopher, was said to have ascended to Heaven, whilst the "Nirmanakaya" of the Buddhists had taught them that one of Buddha's three-fold 
embodiments (Trikaya) was capable of transformation, i.e. metamorphosis. But strange to say it was the Resurrection of our Lord itself that they could not easily accept, whilst some of the literati were altogether opposed to it.

(25) The twenty-seven standard volumes of His Satras. -Of course the Christian New Testament is meant. But this is very difficult to harmonise with the ordinary view, for the Syrian Churches accept only twenty-two of our New Testament books. The Nestorians of East Syria were slow to accept the four disputed general Epistles and the Book of Revelation, nor did these ever find their way into the Peshito Version. That they were recognised by the Nestorians in China in the eighth century is an important point for consideration by students of the Syrian canon.

(26) His ministers carry the Cross. - This is the Cross of Christian symbolism. The author here passes from the work of Christ to that of His ministers and churches. In the East Syriac Daily Offices we find (pp. 57, 144)-"By the Cross of Thy light Thou hast illumined our knowledge;" and again: "His lightnings lighted the world. The Cross of Light which was shown to Constantine in Heaven like a mighty one of the Virtues went at the head of the camp to war. And they were moved and astonished, the companies of the heathen who worships created things; and they left off the error of heathenism and venerated and honoured the Cross."

(27) They travel about wherever the sun shines and try to re-unite those that are out of reach (i.e. beyond the pale).This translation may be disputed. Compare the following different translations :

(Abbe Huc) "The sign of the Cross unites the four quarters of the world, and restores the harmony that had been destroyed."

(Wylie) "As a seal, they hold the Cross, whose influence is reflected in every direction, uniting all without distinction." 
(Legge) "His ministers bearing with them the seal of the Cross, diffuse a harmonising influence wherever the sun shines, and unite all together without distinction."

(Moule) "The figure of ten, which is held as a badge, enlightens the four quarters so as to unite (all) without exception"

But we are justified in translating as we do, because the Chinese character "Jung" (融), being part of a verbal phrase Jung-t'ung (融通), should be rendered "go travelling about" or "melting " or "diffusing." Its original meaning is "to go through" or "to pass from one place to another," or "accommodate," whilst the latter part of the phrase may be rendered "try to reach those that are out of the way" (or "beyond the pale") i.e. lit. "try to catch those for whom there is no catching." The idea is that the Gospel of our Lord is all-sufficient to save even the outcasts and forsaken sinners. (See Hebrews v. 2, 12, 13.)

(28) Striking the wood.-This doubtless refers to the church music of the Nestorian mission in China in the eighth century. That they struck the wood is quite certain, but how and when they did so our Inscription does not say. We think, however, that the time and the way in which they struck the wood in the church services can be made clear to us through "the striking of the wood" preserved in Japanese Buddhism-more especially in the Shinshu (i.e. "The True Religion Sect") founded by the renowned Shinran Shonin (1173-1262 A.D.), who laid the foundation of the Hongwanji Temple at Kyoto.

The wood is four or five inches long and about one inch wide. The priest holds a piece in each hand and strikes the two pieces together. This "striking of the wood" is usually done whilst the priest recites "The Three Books on the Amitabha Doctrine"-the larger Sukhavati Vyuha, the smaller Sukhavati Vyuha, and the Amitayurdhyana Sutras. The reciting or reading of the sutras takes place whilst the wood is struck or chimed in a regular, methodical way. The 
sound assists the Buddhist temple service as the organ does the singing in a Christian church.

This "striking of two pieces of wood" is quite different from the "beating of the board" in Buddhist temples, which is done for utilitarian purposes rather than for musical purposes. For instance, the time to rise or to go to bed in a monastery is indicated by beating the "wood" or "board."

The origin and history of "striking wood" as a part of the musical service in a temple are not fully known. All we know is that the Nestorians struck the wood, and so does the Shin-shu sect of Japanese Buddhism; that "the striking of the wood" is peculiar to the Shin-shu, and that the beating of the "wooden fish" (木 魚) is peculiar to the most ancient Mahayana Buddhist sects in China and Japan.

In India a large gong called "Ghanta" was used, which also found its way via Khotan to China and thence to Japan. This is mentioned by the Chinese pilgrim Fa-hsien (法 顯) in his travels, A.D. 400 . So the two pieces of wood, with a gong, drum, and a pair of symbols, now form the musical instruments of the Shin-shu sect as well as of other sects.

We read in "The Book of Governors" (Vol. II., p. 244): that "when the sacristan rose up to beat the board to summon the congregation for the office of the night; behold, he saw that all the nut-trees had come round about the church, and in his joy he went to where the Bishop was sleeping to announce to him the departure of the trees." This is quite different from the above-mentioned "striking of the wood" or the beating of the "wood-fish."

(29) They turn ceremoniously to the East.-Worshipping toward the East is the regular Nestorian custom. A most interesting passage from "The Book of Governors," Vol. II., p. 274, translated by Dr. Budge, throws great light not only on the eastward position of the Nestorian use, but also upon their clerical life in the seventh and eighth centuries.

"And once when he (Bishop Mâran-Zěkhâ) was journeying 
along the road to that mountain (the mountain of the village of Zinai), he saw the figure of a man standing on the top of a hill with his face turned towards the East, and as he drew near to it, he heard him raising (his voice) in the hymn of the Resurrection from the Communion Service of the first day of the week, which beginneth, 'Come, all ye peoples, let us move our lips,' and little by little he went up and came close to him. Mâran-Zĕkhâ, before he perceived that man, wondered how this pastor of camels was able to sing this hymn which was so difficult that not every man was capable of singing it, and where he had learned it ? And when the holy Mâran-Zěkhâ saw him he marvelled, and cried out in the customary way 'Peace'; but that blessed man answered him in Arabic, speaking in barbarous language wishing to disguise himself.

"Bishop Mâran-Zěkhâ fell down before him and affirming with oaths said, 'I will not rise up until thou dost promise me that thou wilt not hide from me who thou art.'- 'If thou art an Arab as thou sayest (by the speech), where didst thou learn this hymn of the Resurrection of our Lord which very few men are found to have ability enough to sing ? and why were thy arms and face turned toward the East?' . . . And he answered, saying, 'Behold, Master, forty years ago I was appointed Bishop of the Scattered who were in the land of Egypt. When I had ministered in this office a short time, a scarcity of rain took place there, and I gathered together the believers and went forth (with them) to the desert to make supplication and entreaty to God. And those Arabs who dwell in tents surrounded me, and while every one else escaped, I remained, because I thought that they would do me no harm; and they took me captive and brought me to their tents, and appointed me to be the shepherd of these camels which thou seest-I remembered that many of the saints were shepherds, and I am comforted. And as for this hymn which thou didst hear to-day, behold 
I am accustomed each day to perform the service of festival of the Lord, and to watch, and to-day I performed the service of the Resurrection of our Lord, and lifted up my voice in the hymn as if I had been standing in the temple before the altar of our Lord."

(30) They preserve the beard,--they shave the crown.-This symbolic explanation is very curious. There is no end to the possible reasons.

The Buddhist priests shaved the crown, and so did the Nestorians. The upper class Chinese and literati at that time wore beards, and so did the Nestorian missionaries. The Nestorians seem to us to have adopted good things from others, and explained their reasons for so doing.

The custom seems to us to be reminiscent of the words of our Lord recorded by St. John xvii. 15, "I do not ask Thee to take them out of the world, but to keep them from the evil."

Some of the Nestorian priests were high officials in the Chinese Court, and others even occupied military positions as staff officers, vested in their monastic robes, as shown in the Inscription itself. (See also p. xcix. Vol. I., Yule's "Cathay and Way Thither.")

That upper class society in China was considerably influenced by the Nestorian's theistic conceptions of the world, may be seen from the contemporary writings of the T'ang period.

(31) They observe fasting in order that they may subdue "knowledge"-they keep the vigil so that they may keep "precept."-The word "knowledge" in this phrase is an especially Buddhistic one. It is the Chinese for the Sanskrit "vidjnana," and means a "knowledge of what defiles the mind." To subdue "knowledge" is to purify various sense-organs.

This expression is a counter-part of the phrase "purging away the dust" used in the Inscription. What is called 
"exemption from all knowledge" is the fifth of the Dharmakaya attributes. "Observing the Precepts" means again exemption from all materialism ("rupa") in which lust comes first.

(32) Seven times a day . . . prayers for the dead.-This is what the Japanese Buddhists call “e-ko" (司 向) (lit. " turn toward").

In other words, "To comfort the spirit of the departed through the merit and virtue of the reading of satras, and by virtue, or the sheer force of prayers offered or said by the living, so as to make the departed turn toward (the living). The Buddhist 'Communion of Saints' is meant by 'e-ko." "

The idea is very familiar to all the Japanese as well as to the Chinese. Thus whether consciously, or unconsciously, Buddhists admit the existence of the soul, or else it were useless to pray for the dead if they be indeed dead in body and soul (i.e. absolutely extinct). This prayer for the dead is most natural to those who believe in the survival of the Soul and in the life beyond the Tomb.

The Nestorians were great believers in the prayer for the dead. The names on their Diptychs were recited every time at their worship. The idea of Ancestral commemoration naturally led to prayers being offered for the departed as well as for those that are living.

The Shin-gon shu (黄言宗) pray for the living and for the dead more than any other Buddhist sect, whilst the Shin-shu (㨁宗) do not pray一at least profess not to pray -for the living at all. They do not pray even for the dead in the sense that other sects do.

This fact was well proved at the time preceding and following the death of our late Emperor (on the 3oth of July, 1912). All sects, whether Shinto, Buddhist, Christian or non-Christian, prayed for the recovery of the Emperor's health, with the exception of the Shin-shu who could not 
participate in doing so. Dr. M. Anesaki, professor of Comparative Religion in the Tokyo Imperial University, in writing to the Tokyo Asahi Shimbun (the largest paper in Japan) on the 3rd of August, 1912, emphasised this point.

(33) Once in seven days . . . a sacrifice without animals.The Chinese character "chien" (荡) really means "a sacrifice without an animal." It is quite clear from these words that the celebration of the Holy Communion was observed weekly by the Assyrian Church in China. "Once in seven days" of course means "once a week on the First day"-for they kept Sundays and not the Sabbath or Seventh day.

(34) This ever true and unchanging Way is my'sterious, and is almost impossible to name.-This expression must have been derived from Taoism. Compare these words with those of Lao-tzŭ: "The Way, so long as it remains absolute, is unnameable"; or with "When obliged to give it a name, I made an effort to call it The Great Way." (Chapters xxv. and xxxii., of the Tao-tê-ching.)

That Adam, the author of the Nestorian Inscription, though a Persian by birth, was as well versed in Taoism as in Buddhism is quite evident.

(35) But at any rate, The Way would not spread so widely had it not been for the Sage, and the Sage would not have been so great, etc.-These are perhaps the most difficult expressions in the whole Inscription. Compare the following translations:

(Huc) "Learning alone without sanctity has no grandeur; sanctity without learning makes no progress. When learning and sanctity proceed harmoniously, the Universe is adorned and resplendent."

(Wylie) "Now without holy men, principles cannot become expanded; without principles, holy men cannot become magnified; but with holy men and right principles, united as the two parts of a signet, the world becomes civilised and enlightened." 
(Legge) "But any (such) system without (the fostering of the sage (sovereign) does not attain its full development, and a sage (sovereign) without the aid of such a system does not become great. Let the sage (sovereign) and the (right) system came together like the two halves of a seal or convenant, and the world will become polished and enlightened."

(Moule) "Doctrine without a prophet will not flourish; a prophet without doctrine will not be great; when the doctrine and the prophet are closely united the world is civilised and enlightened."

In the Inscription, the Chinese character (惟) is used which can be read either "indeed," or "really" (維), or "only" or "alone" (唯). In some cases it is read for "at any rate." Here again the calligrapher exercised the privilege of which we have already spoken.

In the Inscription the character literally means "only," but "at any rate," or "however" is also possible. "The Way" means "the True and Unchanging Way" mentioned above. That is to say, Christianity ("the True Way") would not have spread so widely had it not been for the Sage.

According to Chinese ideas, "shêng" or Sage means (I) omniscience personified, or (2) omniscient man, or (3) perfect virtue and perfect knowledge personified in a sovereign. Here, no doubt, Adam, the author, employed the word in the sense of No. 3, "Omniscience personified in the Sovereign " or "All-knowing:"

(36) Tai-Tsung, the Emperor.-This is the posthumous name of $\mathrm{Li}$ Shih-min (李世 民), the second son of Li Yüan, known in the annals of T'ang as Kao-Tsu, the founder of the Dynasty, A.D. 6r8.

Li Yüan had two other sons-one older and one younger than T'ai-Tsung. The elder was the Crown Prince, who from mere envy, if we believe Chinese history, united with the younger brother, known as Prince $\mathrm{Ch}^{\prime} \mathrm{i}$ (弯王), in trying to 
murder T'ai-Tsung; but $T^{\prime}$ 'ai-Tsung was more than a match for them, as he killed them both in 626 A.D., and after this bloody deed compelled his father $\mathrm{Li}$ Yüan to abdicate, and himself ascended the throne in 627 A.D., nine years before the Nestorian mission came. The death of $\mathrm{Li}$ Yüan was also mysterious and bloody. Some say that $T$ 'ai-Tsung was responsible for it! But T'ai-Tsung was one of the best rulers that China ever had.

(37) A-lo-pên. - That A-lo-pên or Alopun is a Syriac name there is no doubt. The "alo" or "olo" is an equivalent found in many Hebrew names beginning with "eli" or "el" -Elijah, El-nathan, etc.

We insist that this A-lo-pên or Alopun is a personal or proper name, although ever since Sir Henry Yule started "the Alopun-Rabban theory" many years ago, almost. all the recent writers have implicitly followed him. He says : "O-lo-pan-this name according to Pauthier is Syriac, Alopano signifying the 'Return of God '." If this, however, is an admissible Syriac name, it is singular that the original should have been missed by one so competent as Assemanni, who can only suggest that the name was the common Syriac name Jaballaha, of which the Chinese had dropped the first syllable, adding a Chinese termination.

"Might not Olopan be merely a Chinese form of the Syriac Rabban, by which the apostle had come to be generally known?

"It is fair, however, to observe that the name in the older versions used by Assemanni is written Olopuen, which might have disguised from him the etymology proposed by Pauthier. The name of this personage does not appear in the Syriac part of the Inscription." ("Cathay and the Way Thither," Vol. I., p. 94.)

Mr. Moule says- "The identification of A-lo-pen with the Syriac Raban is due to Colonel Yule, who is followed by Cheikho and Havret." 
Dr. K. Shiratori, professor of Oriental History in the Imperial University, Tokyo, also holds the same view. He says that "these Chinese always borrow one of the " $a$," " 0 ," and " $u$ " sounds to pronounce a proper noun beginning with the " $r$ " sound ; for instance, they pronounce "O-russia" for "Russia." So this "Olopan " in Chinese would represent "Lopan," every " $r$ " becoming " 1 " in Chinese pronunciation. "Rabban" would, according to his theory, be the nearest possible equivalent of "Alopan."

But various reasons compel us to question this "AlopenRabban theory."

First of all, it is not necessary to conclude that the Chinese cannot pronounce any foreign names beginning with a vowel because they always borrow " $a$ " or " 0 " to pronounce foreign names beginning with " $r$."

Secondly, in the Inscription A-lo-pên is called "Shangtê"-i.e. "Shang-tê A-lo-pên." "Shang-tê" literally means "High Virtue," and this honorific title may correspond to the Syriac "Rabban," as "Ta-tê,". Great-virtue, may do to the title of a "Bishop"-e.g. "Bishop George" who in the Inscription is designated "Great-virtue Giwargis." And, strange to say, this "Ta-tê," Great-virtue, was commonly used by-the Buddhists whilst Taoists preferred "Shang-tê," High-virtue. This is another point which proves that the Nestorians in China adopted anything they thought was good whether it came from Buddhism or from Taoism.

If we accept the "Alopen-Rabban theory" we must translate "Shang-tê A-lo-pên," High-virtue A-lo-pên, into "Rabban Rabban." That "Great-virtue" stands for "Bishop," and "High-virtue" for "Rabban" appears to us to be certain, whilst that the one is Buddhistic and the other Taoistic is abundantly proved from Chinese sources.

This Rabban A-lo-pên was afterwards made the "Patron and Spiritual Lord of the Empire," and styled "Greatvirtue A-lo-pên," or Bishop A-lo-pên, as in another part 
of the Inscription. So he must have been already a Bishop when he arrived in China at the head of his missionary monks. His name appears thrice in this Inscription-once as "High-virtue A-lo-pên," then "Great-virtue A-lo-pên," and lastly without any honorifics. This shows that "A-lopên" was regarded by the Chinese as a personal proper name beyond all doubt.

Thirdly, Etheridge, the author of "the Syriac Church," gives also Yabh-allaha for "Alopen" (after Assemanni) and interprets it as "the Conversion of God."

The name "Yabh-allaha" occurs more than once in the famous "Book of Governors"; and this agrees with what Assemanni said, that the name was an ordinary Syriac one. "The Book of Governors" says that one Yabh-allaha was the founder of monasteries in Babylonia and Arabia in 385 A.D. Another Yabh-allaha was Bishop of Gilan, and brother to Kardagh, both of whom did good work in Central Asia during the Patriarch Timothy's reign (781-824 A.D.). (See "The Book of Governors," Vol. I., p. cxxxi.)

Finally, our view is confirmed by a newly discovered Inscription which is seventy years older than the Nestorian Inscription itself.

It is called "The Inscription on the Stone-tablet set up in memory of the late great Persian chief, the General and commander of the right wings of the Imperial Army of T'ang (i.e. China) with the title of Grand Duke of Chin-ch'êng chün (in Kan-su) and the Rank of Shang-chu-kuo" (上 柱 國) (lit. The first-class corner-stone of the Empire). In the first line we have the name "A-lo-han" (阿羅诚). It runs :

"This is the Stone-tablet erected in memory of A-lo-han, a Persian prince by birth and the most illustrious of the whole tribe."

For the full text of the Inscription, see Appendix No. I.

To. say that "A-lo-pên" is a personal proper noun is 
one thing, but to identify him with "Yabh-allaha" is quite another.

Although Assemanni and M. Pauthier may be correct in suggesting "Yabh-allaha" for " A-lo-pên," we should like to point out that "Lo-han" (羅含), whether in the Nestorian Inscription at Hsi-an-fu or in the Jewish Inscription at K'aifêng-fu in Honan, stands for "Abraham," and we are therefore tempted to surmise that "A-lo-pên"-whose Japanese sound is "Arohon"-is originally the same as that found in the newly-discovered Inscription, viz. "Alohan," which would be sounded "Arohan" by the Japanese, by whom the T'ang sound of the Chinese letters is far better preserved than among the modern Chinese.

If we compare the Chinese characters for "Lo-han" and "A-lo-han" or "A-lo-pên," we cannot fail to see that what we assert is founded on a sound basis.

(38) The Kingdom of Ta-ch'in.-This Kingdom means Judea as in note seventeen where the Birth of our Lord is mentioned. Here probably it indicates more particularly the Province of Syria in the Roman Empire of the Orient.

(39) He decided to carry the true Sintras.-Here, again, the usual Chinese character for the Buddhist word "Sutras" is employed. The word "Sûtras" of course means "Canon," and may mean "the Holy Scriptures," or "The Bible." We feel certain from the other part of this Inscription, as well as from Prof. Pelliot's recent discovery, that the Bible, or at least a great part of the Holy Scriptures, must have been translated into Chinese by the end of the eighth century A.D.

(40) Chêng-kulan Period.-This period lasted twenty-three years, and exactly corresponds to the reign of the Emperor T'ai-Tsung, who, on the abdication of his father in 627 A.D. ascended the throne and named the Era "Chêng-kuan." He died in A.D. 649.

The ninth year of Chêng-kuan (A.D. 635) was that in 
which the mysterious death of his father, the abdicated Emperor Li Yuian, occurred. The arrival of the Nestorian Mission was also in that same ninth year of the Cheng-kuan period (A.D. 635).

(4I) Duke Fang Hsiuan-ling.-This man was one of the four greatest statesmen who lived and died during the three hundred years of the T'ang Dynasty. Amongst these fous statesmen, Fang Hsüan-ling and Tu Ju-hui 杜如管 belong to the reign of T'ai-Tsung, Yao Ch'ung 姚崇 and Sung Ching to that of Hsuian-Tsung, 7 13-754 A.D.

Duke Fang was born at Lin-ssŭ (臨 泗), 577 A.D. His father was the Governor of Ching-yang (涇 陽). When T'ai-Tsung marched against the Northern Wei with his army in 613 A.D., Fang Hsüan-ling, at the head of his clan, offered himself to the Emperor's service, and ever after they were great friends. He was a man of learning and culture, and is considered to have been the very best type of a faithful and capable Minister. He served the Emperor T'ai-Tsung as Minister of State for fifteen years, and held a position in China similar to that which Prince von Bismarck held in recent years in Germany.

(42) The Sitras were translated, etc.-We are not yet in a position to say which parts of the Bible were actually translated. The word "sutras" used here literally means "standard books," and may mean the Bible, or the Scriptures, but it may also mean the Church literature.

In the year 1908 A.D., Prof. Paul Pelliot found a list of the names of some 35 Nestorian "sutras" translated into Chinese besides 22 Diptychs in Chinese at Sha-chou, China. Although we cannot identify them all, it is certain that the term "Satras" is used for anything which resembles a "Catechism" or a "Commentary." And in our Introduction we mentioned how Adam, the author of the Nestorian Inscription, was engaged in translating the Buddhist scriptures. If the Assyrian monks could spare time to 
translate Buddhist works as well as their own literature, how much more time they must have given to Bible translation!

So the expression "the sutras were translated" may mean the translation of parts, if not the whole, of the Bible. That capable men were found to aid the missionaries in translating Christian literature into Chinese may be clearly seen both from the composition and the style of the Nestorian Inscription.

(43) The Imperial Rescript.-The attitude of the Emperor $T$ 'ai-Tsung towards Religion in general, whether Christianity or Buddhism, is well disclosed in this Rescript. We give different translations so that the real meaning of the Chinese Emperor may not be misunderstood :

(Abbe Huc) "In the twelfth year of Tching-Kouan in the seventh moon, during the autumn, the new Edict was promulgated in these terms :

"The Doctrine has no fixed name, the holy has no determinate substance; it institutes religions suitable to various countries, and carries men in crowds in its track. Olopen, a man of Ta-Thsin, and of lofty virtue, bearing Scriptures and images, has come to offer them in the Supreme Court. After a minute examination of the spirit of this religion, it has been found to be excellent, mysterious and specific. The contemplation of its radical principle gives birth to perfection, and fixes the will. It is exempt from verbosity; it considers only good results. It is useful to men, and consequently ought to be published under the whole extent of the heavens. I, therefore, command the magistrates to have a $\mathrm{Ta}$-Thsin temple constructed in the quarter named I-ning of the Imperial city, and twenty-one religious men shall be installed therein."

(Legge) "Systems have not always the same name; sages have not always the same personality. Every region has its appropriate doctrines, which by their imperceptible influence benefit the inhabitants. The greatly virtuous Olopun of the 
kingdom of $T \hat{a}$ Ts'in, bringing his scriptures and images from afar, has come and presented them at our High Capital. Having carefully examined the scope of his doctrines, we find them to be mysterious, admirable, and requiring nothing (special) to be done; having looked at the principal and most honoured points in them, they are intended for the establishment of what is most important. Their language is free from troublesome verbosity; their principles remain when the immediate occasion for their delivery is forgotten; (the system) is helpful to (all) creatures, and profitable for men :let it have free course throughout the empire."

(Wylie) "Right principles have no invariable name, holy men have no invariable station; instruction is established in accordance with the locality, with the object of benefiting the people at large. The Greatly Virtuous Alopun of the kingdom of Syria, has brought his Sacred books and images from that distant part, and has presented them at our chief capital.

"Having examined the principles of this religion, we find them to be purely excellent and natural; investigating its originating source, we find it has taken its rise from the establishment of important truths; its ritual is free from perplexing expressions, its principles will survive when the framework is forgot; it is beneficial to all creatures; it is advantageous to mankind. Let it be published throughout the Empire, and let the proper authority build a Syrian church in the capital in the E-ning Way, which shall be governed by twenty-one priests. When the virtue of the Chow dynasty declined, the rider on the azure ox ascended to the west; the principles of the great $T$ 'ang becoming resplendent, the Illustrious breezes have come to fan the east."

(Moule) "Teaching has no immutable name, holy men have no unchanging method. Religions are founded to suit (respectively, different) lands, that all the masses of men may 
be saved. Raban of the land of Syria, a man of great virtue, bringing Scriptures and images from far has come to offer them at the chief metropolis. The meaning of his religion has been carefully examined; it is mysterious, wonderful, full of repose. His fundamental principle has been reviewed; it fixes the essentials of life and perfection. In its outward expression there is no multitude of words; in its inward principle there is (laying stress on the end,) forgetting the means. It is the salvation of living beings, it is the wealth of men. It is right that it should spread through the domains of the Empire. Therefore let there be built in the I-ning quarter of the metropolis a monastery of Syria, and let twenty-one men be duly admitted as monks. When the virtue of the ancestral house of Chou failed, the dark chariot went up toward the West ; now that the doctrine of the great house of T'ang is bright, a favourable breeze blows towards the East."

We are quite sure that the Imperial Rescript ends with the word "Empire"; and that the words-" the proper authorities accordingly, etc."-were not included therein. But Huc, Wylie, and Moule treated these words as though they were included in the Rescript.

We consider that Dr. Legge was perfectly right on this point, and that the other translators must have overlooked the important Chinese adverb (即) "accordingly" or "upon this."

What is recorded in "the T'ang Hui-yao" (唐會 要) may be cited against our opinion, but that book, although originally written in 982 A.D. (as all scholars know), was

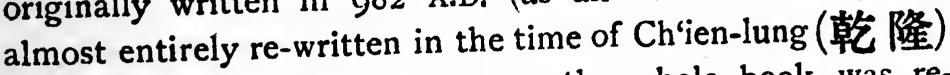
1736-1795 A.D. That is to say, the whole book was recompiled more than a hundred years after the newly discovered Nestorian Inscription itself was made known to the literary world in China, and the text in the old T'ang Hui-yao was possibly "improved" in the revision. 
At any rate, the Imperial Proclamation, or Rescript, begins with "The Way had not, etc.," and ends with the words "throughout the Empire." How far the Emperor borrowed the idea for his Rescript from Taoism may be readily seen by comparing Lao-tzŭ's words in the Tao-têching (道德釈).

"The Way that can be named as a Way is not the Eternal Way." "The name that can be named (as a Name) is not the Eternal Name." Again, in Chapter XXXII. of Lao-tzŭ's book, we read :

"The Way, so long as it remains absolute, is unnameable."

The Emperor Tai-Tsung's opinion of the Nestorian Teaching, twelve hundred and thirty-five years ago, is the very same as that which the majority of intellectual Japanese and Chinese hold to-day. The Japanese poet who sang :

“Wa ke no bo ru

Fu moto no michi wa

Kotonare do

Onaji takane no

Tsuki wo miru kana."

"By differing Ways the mountain height we climb

For one intent,- the Moon that shines sublime!"

pretty nearly expressed what $T$ 'ai-Tsung intended to say in his Edict. But this attitude of the Chinese Emperor and his people explains why religious persecution pure and simple never took place in the Far East. What is called "Religious Persecution" in the history of China and Japan was not usually caused by religion, pure and simple, but by political or "economic" reasons.

That the Chinese were either very liberal or very indifferent-they were then far from entertaining an exclusive and self-conceited race feeling-can be seen from these words of the Emperor:

"Truth is often of a dual character, taking the form of a 
magnet with two poles; and many of the differences which agitate the thinking part of mankind are traced to the exclusiveness with which partisan reasoners dwell upon one half of the duality in forgetfulness of the other."

We think that Alexander Pope was right in saying, "There is nothing wanting to make all rational and disinterested people in the world of One Religion, but that they should talk together every day."

(44) Ta-ch'in Monastery.-This name must have been used ex post facto, for we read in the Imperial Edict of the Emperor Hsiuan-Tsung that the monastery acquired the official name of the "Ta-ch'in Monastery" for the first time in 745 A.D. Prior to that date it was known as "the Persian Monastery." That Imperial Edict says :

"The Luminous Religion of Persia was originally started in Ta-ch'in. It is long since this Religion came to be preached here. Now it is practised by many, spreading throughout the Middle Kingdom. When they first built monasteries we gave them the name of 'Persia-Temple' (because of their supposed origin). In order that all men might know the (real and true) origin of what are commonly known as 'Persian monasteries' in the two capitals (the names) are henceforth to be changed to the Ta-ch'in Monasteries. Let those also which are established in all parts of the Empire follow this (example)."

This shows that there was more than one Nestorian Monastery in the capital, whilst it also shows that the official name "Ta-ch'in Monastery" originated in 745 A.D., although the monastery itself was founded in 638 A.D., three years after the arrival of the Nestorian missionary band under "the Great-Virtue A-lo-pên."

(45) The I-ning Ward. - The word "I " means "Righteousness," whilst " ning" means "Repose." The ward was on the left-hand side facing towards the Imperial Palace, and in the second street below the Imperial Palace. 
The city of Hsi-an-fu (i.e. Ch'ang-an) was planned almost square, as we see in the old map. The Japanese city of Kyoto was built after the model of Ch'ang-an about twelve hundred years ago. If we compare Kyoto with Ch'ang-an we find that where the Nijo Castle now stands would be the spot where the Ta-ch'in Monastery was built by Imperial order for the Nestorians in 638 A.D., and one street lower down and one street towards the centre would be the Buddhist convent where our Kobo Daishi dwelt when he was in Ch'ang-an during 804-806 A.D.

(46) Twenty-one priests were ordained and attached to it.These twenty-one priests may have been Chinamen. A few years must have elapsed before the monastery was built, and twenty-one persons fitted to receive Ordination.

Our author, Ching-ching (Adam), goes on to describe how this newly-built monastery was adorned with the portrait of the great Emperor T'ai-Tsung.

That the monastery was built and supported by the Government is clearly seen from the force of the term "attached to it," in addition to its title "ssŭ" (寺)—“Tach'in-ssŭ" (see note 5, p. 185, supra).

(47) The virtue of the honoured House of Chou had died away.-This means that the great moral influence exercised by such men as the Duke of Chou (周公) (770-727 B.C.), and by Confucius (55 I B.C.) and his followers, had departed long before the T'ang Dynasty arose to restore the moral code of the nation by means of its good government, for the chief reason for political revolution in China has always been the maintenance of the moral code of the nation.

"The reign of Duke of Chou" in Chinese thought means the Golden Age of the past and the Ideal state of the future.

In Hebrew thought the Mosaic Age meant much the same. And in China the past Golden Age or "ideally-fulfilled State" was the reign of the Duke of Chou.

On the one hand the degenerate condition of China had 
continued ever since the virtue of the honoured House of Chou disappeared; the prevailing disorder was the result of this. And this fact was a very good reason why $T$ 'ai- $T$ sung and his father should supplant the Sui Dynasty. On the other hand, the "rider on the black chariot," i.e. Lao-tzŭ (604 B.C.), having ascended to the Western Heaven, the Chinese people had been left without moral guidance; and this might be utilized as a good argument for the Nestorians' coming to China and bringing a Religion for the Chinese millions.

As in politics the T'ang supplanted the Sui Dynasty, so in religion the Nestorians ought to succeed the Taoists. These are the ideas conveyed in the expressions of the Inscription.

(48) "The rider on the black chariot."-In this expression the author alludes to the old philosopher Lao-tzŭ who disappeared from the country on such an animal, and was supposed never to have died. The meaning of these two sentences is: "The virtue of the honoured House of Chou had died away; the rider on the black chariot having ascended to the West, darkness reigned throughout China. But virtue revived and was manifested once more at the moment when the great Tang Dynasty began its rule, and the breezes of the Luminous Religion blowing Eastward refreshed it."

Among the fragments of old documents found by Prof. Paul Pelliot at Sha-chou (沙州) in 1908, there is a book entitled "The Sûtras explaining Lao-tzŭ's ascent to the Western (Heaven) and His Incarnation in the Land of $\mathrm{Hu}$ " (老子西早化胡經). In other words, “A re-incarnation of Lao-tzu in the Western Land." The author of this book suggests another Incarnation of the Tao (道) or “Way" (i.e. the Logos in the Chinese sense).

It is remarkable that the founder of the White Lotus Guild in Southern China Hui-yuan, the disciple of Tao-an, the Chinese monk from Che-kiang who learned the Mahayana 
literature at Yeh (業都) (Chang-tê-fu) in Northern China in the middle of the third century from Buddho-chinga, a monk from Gandhara in India, taught that the books of Lao-tzù were a necessary introduction to the teaching of Ashvaghosa and Nagarjuna; just as St. Paul said that the Law was a schoolmaster to bring the Jews to Christ. And this White Lotus Guild taught the Amitabha-Doctrine of Salvation by Faith.

The personal name of the author of the book discovered by Prof. Pelliot is lost, and there is no knowing who and what he was; but he evidently tried to argue that the Sages in the West, whether Sakyamuni or others, were but re-incarnations in their respective lands. He insisted that the Sages were all the same; and that if they were not the same, they could not be Sages. The differences between thern, according to this author, are only in name or appellation.

And this agrees with the opinion expressed by the Emperor $T$ 'ai-Tsung as preserved in the Nestorian Inscription: "Sages have no fixed or immutable body."

(49) A faithful portrait of the Emperor.-This must be the first time that the Chinese Emperor's portrait was ever painted on the wall of a Christian monastery. Many years afterwards when Hsuian-Tsung (742-792 A.D.) sent the five Imperial portraits to the monastery, he only followed the good example set by the Emperor T'ai-Tsung in 638 A.D.

Fresco portraits painted on the wall were at that time quite fashionable, as is proved by those discovered lately at Khotan (于聞) and in the Caves of the Thousand Buddhas at Tun-huang (敦煌千佛洞) in Central Asia, by Sir A. Stein as well as by the Rev. $Z$. Tachibana and Prof. Pelliot.

(50) According to the descriptive Records of Western Lands, and the historical works of the Han and Wei Dynasties, etc. - This description of $\mathrm{Ta}$ ch'in by the Nestorian missionarypriest in the eighth century makes the identification of Ta-ch'in rather difficult. 
It is no wonder that Dr. Legge, despite all his knowledge of China and things Chinese, regretfully says: "I could wish that this paragraph about $\mathrm{Ta}-\mathrm{Ts}_{\mathrm{s}}$ in had not been put in the Inscription, and it is difficult to perceive the object which it serves."

We partly agree with this great Sinologue. But, apart from its original aim and purpose, does not this paragraph reveal to us the progress of the world in the course of twelve hundred years and that :

"Through the ages one increasing Purpose runs,

And the thoughts of men are widened with the process of the Suns"?

It was once so believed by the Nestorians and others in China!

Besides, this proves how keen the missionaries were in describing the good things in the home-land. The land of Buddha had hitherto been described as the best country in the world, but now we find the Land of the Luminous Religion described as the ideal country by the author of the Nestorian Inscription, who is quoting old Chinese books.

(51) The Coral Sea.-This expression is not clear. It means either the Indian Ocean or the Red Sea, most probably the latter, for near Aden the coral reefs are dangerous to ships, hence the name of the entrance to the Red Sea, Bab-el-mandeb, "the Gate of Tears," for so many vessels are wrecked there.

(52) The mountain of "All Precious Things."-The Sanskit "Ratnaghiri (珼山) literally means "Precious Mount," and the mountain of that name is located near Rajagriha, the ancient capital of Magadha, India. But we cannot say that this is the mountain meant by the author of the Inscription. All we can say is that the author of the expression was somewhat influenced by, if he did not actually borrow from, Buddhism. 
(53) The Gardens of Immortals and the Flowery Forest.The dwelling of the richi (仙人), Immortals, is known as Sravasti (仙人 住豦), an ancient kingdom, 500 li N.W. of Kapilavastu, Sakyamuni's birthplace, and as a city near the river Sravasti which was a favourite resort of Sakyamuni. As early as the end of the sixth century A.D., it was a deserted ruin whilst the ancient name of Pataliputra (花宮城) was Kusumapura, "the city of Flowery Palaces."

We are far from saying that what is written in the Inscription is to be identified with these Buddhist places, but we say that it is very plain that the expressions are borrowed from Buddhism.

(54) The long winds and the weak waters.-The strong winds, or the winds that blow from a distant place, are often indicated by the expression "long winds." Then the phrase began to denote a great plain or desert from whence the people of that time imagined the winds to spring. In this passage, the "long winds" probably denote the great plain of Mesopotamia.

The Chinese poet, Liu Tsung-yüan (773-819 A.D.) says : "In the mountains on the Western Sea there is a water (river) spreading out and having no strength (coherence); it does not carry even a trifling object, and whatever is put on its surface, will drop down to the bettom and remain therewhence it is called weak water."

The weak waters on which nothing would float were the fabled protection of the Palace of Hsi Wang Mu (西王母). But no one knows who was Hsi Wang $\mathrm{Mu}$ and where she (or he) the mysterious person of Chinese legend dwelt.

"The weak waters" in this Inscription may mean the Euphrates or Tigris. The mythological “Jo-shui" (弱 水) (weak waters) of the Chinese could be navigated only in skin boats. The idea is a familiar one to the ancients. Compare Herodotus (III., 23) who describes a fountain in Aethiopia, the water of which was so weak that nothing can float upon 
it, neither wood nor such things as are lighter than wood, but everything sinks to the bottom."

(55) The soul-restoring incense.-The incense most commonly known in Japan is "the Ansoku-ko," i.e. "An-hsi incense," which simply means "Parthian incense," "An-hsihsiang” (安息香), being the Chinese corruption for Arsakes, the founder of the Parthian Empire. This "soulrestoring incense" is very well known amongst the Japanese. It was no doubt introduced into Japan from Ch'ang-an.

"The soul-restoring incense" is, of course, different from the "An-hsi incense," because their uses are quite different. The name of the soul-restoring incense is also well known to us through the popular literature in which its name very often occurs.

(56) The Emperor Kao-Tsung.-He was the son of T'aiTsung, his mother being the Empress Chang-sun. In Chinese history he is known as a great Taoist. In 666 A.D., he went himself to Hao (傍), the native place of Lao-tzŭ, to visit the old Philosopher's temple in person, and bestowed the posthumous honour of "the greatest Sovereign Lord of the Most Mysterious Origin" upon that great Taoist Teacher.

It was during this Emperor's reign that the famous Chinese Shan-tao،Ta-shih (羔真大的) lived and died A.D. 6r2-680, whilst his teacher Tao-ch'o Ta-shih (導綽大所) died in 645 A.D. It is very curious that the name of the Japanese Buddhism reformed by Shinran Shonin should bear the same name as that mentioned in the Inscription, viz. "the True Religion" (信宗), and that for both precisely the same Chinese ideograph is used. Is it any wonder that the Nestorians made progress under an emperor like this KaoTsung?

(57) He caused monasteries of the Luminous Religion to be erected in every Prefecture.-Similarly, in 690 A.D., the Empress Wu, as Chinese history records, "caused monasteries 
of the Great Cloud Religion (大雲寺) to be erected in every Prefecture."

According to the Ch'ang-an Topography by Sung Min-ch'iu (995 A.D.) the Hai-yen Ward, where the first monastery of this "Great Cloud Religion" was built, was not far from the I-ning Ward where the first Nestorian monastery was built. The Emperor T'ai-Tsung, it is said, wrote the tablet inscribed with the four Chinese characters, "Great-Cloud-Bright-Light" (大零光明) on it, and gave it to "the Great Cloud Religion" monastery.

Again, in 741 A.D., the Japanese Emperor Shomu followed the good example of the Chinese emperor and caused a Buddhist monastery to be built in every province of Japan (國分寺制).

The Monastery in every prefecture mentioned in the Nestorian Inscription was the first example of the kind. So we may say that the Japanese "Koku-bun-ji," i.e. "a State-monastery in every Prefecture," may be very indirectly connected with the Nestorian Church in China.

Many Chinese authorities are inclined to think that this "Ta-yün ssŭ," "the Great Cloud Religion monastery," built by the Empress $\mathrm{Wu}$, was a Manichean temple, whilst others try to identify it with a Nestorian monastery.

Personally we believe the monastery of the "Great Cloud Religion" to have been a Mosque. Mohammedanism in China began by Mohammed sending his own maternal uncle, Wah Abi Kobsha, by sea as an envoy to the Emperor T'aiTsung in A.D. 628, who granted authority to build mosques in Canton together with the free exercise of the religion. (Dabry de Thiersant: "Mahométanisme en Chine," I., 86-97.)

Moreover, as it was either from the priests of the "Great Cloud Religion" or of the Nestorian Monastery that the Chinese government obtained interpreters of the Uigur language (四鹃)一the men of the Uigur tribes were faithful 
mercenaries to the Chinese Emperor Hsuan-Tsung in $\mathbf{7 5 5}$ A.D.- they probably spoke the same language if they were not of the same religious belief.

(58) Ten provinces.-In his first year (627 A.D.) Tai-tsung divided the whole empire into "Shih Tao" or Ten Provinces, viz.-

(I) Kuan-nei (閶 內), lit. "within the citadel" or "inside the Gates." The province was called by different names in Chinese history,-Kuan-chung (閶 中) (Ch'in, 255-206 B.C.); Wei-nan (渭南) (Han, 206 B.C.-25 A.D.); Yung-chou (碓州) (Eastern Han, 25-22I A.D.); Yunghsing (永具) (Sung, 960-1127 A.D.); An-hsi (安西) (Yüan and Ming, I260-1644 A.D.). It belongs to the present province of Shensi (㣏西省), and its capital is the famous city of Hsi-an, the ancient capital of all China.

(2) Ho-nan (河 南), lit. "South of the River." Its literary name is Yü-chou ( present Honan and Shantung.

(3) Ho-tung (河 東), lit. "East of the River." It is part of the ancient Chi-chou (N), and corresponds to the present province of Shansi (山西省).

(4) Ho-pei (河 北), lit. "North of the River." It comprised parts of the ancient Chi-chou ( (睁州), and corresponds approximately to the present province of Chihli (直楚得).

(5) Shan-nan (山南), lit. "South of the Mountain." This represented the ancient Ching-chou (制州) and Liang-chou (溜州), and corresponds to the present province of Hupei (湖北喼).

(6) Lung-yu (㜔右), lit. "the right side of the Mountain called "Lung." It is the ancient Ch'in-chou (热), and belongs to the present province of Kansu (甘襱).

(7) Huai-nan (淮南), lit. "South of the Huai." Anciently called Yang-chou (控州). It corresponds now to the province of Anhui (妍得). 
(8) Chiang-nan (江 南), lit. " the South of the Yangtzekiang." It was a large province comprising the two present provinces of Chekiang (浙江省) and Kiangsi (江西省), and large parts of Kiangsu, Fukien, and Hunan.

(9) Chien-nan (劒 南), lit. "the South of Mount Chien." Its ancient name is not known, but it formed a part of the ancient Liang-chou (梁州), and is now a part of the Ssŭch'uan province (四川省).

(I0) Ling-nan (嶺南), lit. "the South of the Mount (Ling,)" corresponded to the South part of the ancient Yangchou (掦州). Its literary name is Yuieh-tung (爱東). The two southern provinces, Kuangtung (廣東省) and Kuangsi (廣西省), were included in the province of Lingnan in the time of the Emperor T'ai-Tsung.

In our Introduction we have said that Kuan-nei (關內) must be the "Kumdan" of the Nestorian Inscription, since that very name "Kuan-nei" is pronounced "Kandai" by the modern Japanese-a fact which leads us to conclude that the name Kumdan must have been a corruption of "Kandai."

The expression "within the Gates" or "within the citadels" shows how well protected the chief Province (幾內) was. The great capital Ch'ang-an was situated inside the Citadels or Gates as well as surrounded by its own high walls.

The title found in the Syriac part of the Inscription, "The chorepiscopos of Kumdan" or "the head of the Church of Kumdan and of Saragh," may mean the Metropolitan, whose see included the whole province wherein the capital Hsi-an-fu was.

Dr. Legge has pointed out that the use of the expression "Ten Provinces" is a strong confirmation of the genuineness of the Nestorian Monument.

(59) The period of Shing-li (聖曆).-This is one of many year-names of the Empress-Dowager $\mathrm{Wu}$, and lasted only two years, viz. from 698 to 700 A.D. 
The Inscription thus passes from 683 A.D., in which KaOTsung died, to 699 A.D., i.e. about the middle of the Empress Wu's reign, which practically began in 683 A.D., when she usurped the throne by displacing the Crown Prince ChungTsung, the legitimate eldest son of Kao-Tsung and lawful heir to the Throne, and appointing his illegitimate son JuiTsung. This Jui-Tsung was under her thumb, so to speak, and she managed to keep the reins of government in her own hand through that Prince until she died in 705 A.D., when Chung-Tsung was restored to the throne.

During the Empress Wu's reign she changed the name of the Dynasty from T'ang to Chou (周). Hence there were two capitals in China at that time, as the Inscription says.

The city of Lo appears as " the Eastern Capital of Chou," and Ch'ang-an as "the Western Hao," which was the name of the capital of King Wu, one of the greatest kings that ever ruled over the Chinese. The Dowager-Empress Wu claimed descent from the Great King $\mathrm{Wu}$, and adopted all the old Chou names wherever possible.

The period of Shêng-li corresponds to the fifteenth and sixteenth years of Ssŭ-shêng (嗣 聖) of the Emperor Chung-Tsung (中 宗).

(60) The end of Hsien-t'ien (先 天).-This, the first year of the Emperor Hsüan-Tsung, was the last year of the Emperor Jui-Tsung who succeeded Chung-Tsung in 7 IO A.D. This came to pass as Chung-Tsung who had regained the throne from the Empress-Dowager Wu in A.D. 705 was murdered in 710 A.D. Chung-Tsung was succeeded by JuiTsung, who, however, abdicated in favour of his own son Hsüan-Tsung in 712 A.D. This accounts for that year having had two names, the name of "T'ai-chi" (太極) as being the last of Jui-Tsung, and that of "Hsien-t'ien" (先天) as being the first year of the Emperor Hsüan-Tsung.

From 712 A.D. to the end of 755 A.D., China being under 
the glorious rule of Hsüan-Tsung, might be called "the Periclean Era of Chinese history."

Hsüan-Tsung, one of the greatest emperors who ever sat on the throne of China, was the second greatest after the Emperor T'ai-Tsung during the three hundred years of the T'ang Era.

(61) Some inferior scholars, etc.-Compare this with Laotzŭ's words in the forty-first chapter of "Tao-tê-ching":

"When a superior scholar hears of The Way he endeavours to practise it.

"When an average scholar hears of the The Way he will sometimes keep it and sometimes lose it.

"When an inferior scholar hears of The Way he will greatly ridicule and deride it."

Thus, during some thirty years, i.e. from 683 to 612 A.D., the Luminous Religion was in the most difficult position, because the Buddhists were supreme in the reign of the Empress $\mathrm{Wu}$, whilst the Taoists were very influential during the reigns of Chung-Tsung and Jui-Tsung, and also in the early part of Hsüan-Tsung's reign.

How the Nestorians obtained their influence over the great Emperor Hsüan-Tsung is not far to seek. In the first place, it must have been due to the men of whom the Nestorian Papas Adam, Ching-ching (景 淨), speaks in this Inscription.

In the second place, through the foreign intercourse of the time the Nestorians represented the advanced popular party. Without the aid of the Syrian Christians or of the Mohammedans the Chinese could not easily procure "things Western."

(62) Lo-han, Bishop Chi-lieh, and noble men from "the Golden Region." - Priest Lo-han was identified with "Abraham the Metropolitan" (see Note 37); "Ab," the first syllable in his name, was evidently dropped as was customary in China and Japan.

This view is strongly supported by the tamous Jewish 
monument at $K$ ai-fêng-Fu, which was erected in 1512 A.D., and has lately come into the possession of the Anglican mission in China. Nearly the same Chinese characters "Lo-han" (羅 嫨) are used in both Inscriptions for "Abraham."

Bishop "Chi-lieh" was identified with "Gabriel" by Dr. Heller. But in this Nestorian Inscription "Yeh-li" (業利) and “Kuang-tê " (廣 德) both represent “ Gabriel."

We believe that the former is the Chinese phonetization of "Gabriel," whilst the later is the translation of the Hebrew word "Gabriel " which means "Hero of God." "Kuang-te" in Chinese means "Extensive Virtue," which is the most important attribute for a " Hero of God."

“Yeh-li" (粪利) in Chinese is pronounced “Gyo-ri" in modern Japanese, which is much closer to the old Chinese pronunciation of the $T$ 'ang Era than the present day Chinese is. This is a relic of the long intercourse of Japan with China in the Middle Ages.

These facts compel us to conclude that the bishop's name "Chi-lieh" must represent some Persian word whose first letter had the " $K$ " sound, because " Chi-lieh" is pronounced "Kyu-retsu" in Japanese. We are inclined to identify this "Kyu-retsu " with "Cyriacus," that being nearest to the Japanese pronunciation of the Chinese characters.

This Chi-lieh was the Bishop who accompanied the Persian Embassy to China as recorded in the annals of the epoch. Chinese history says that :

"In the twentieth year of the K'ai-yuian period (開 $\vec{\tau})$, in the ninth moon (October) (732 A.D.), the King of Persia sent the Chief P'an-na-mi (潘那密) accompanied by Bishop Chi-lieh to Hsi-an-fu, the capital, as the Persian Envoy.

"The chief was decorated with the Imperial Order of 'Kuo-i' (果教), 'Heroic-Brave,' whilst the Priest was presented with a purple-coloured vestment besides fifty pieces of silk."

This chief, P'an-na-mi, must have been one of the 
noblemen from the "Golden Region" mentioned in the Inscription. Doubtless there were others of whom as yet we are ignorant.

We do not know whether the Nestorians had recovered their influence before this Persian Mission arrived in 732 A.D., or whether it was in consequence of its arrival. But, as the Emperor Hsüan-Tsung ascended the throne in 713 A.D., what the Inscription records must have occurred after 732 A.D. of the Emperor's reign.

(63) The Emperor Hsiinn-Tsung.-He was the third son of the Emperor Jui-Tsung. Although his eldest son, Ch'êngch'i (成器), was proclaimed Heir Apparent in 710 A.D., he resigned the heritage in favour of his younger brother, P'ing-wang (平王), i e. "Prince of Peace," who was later known as the Emperor Hsuian-Tsung.

This Prince Ch'êng-ch'i, the elder brother to the Emperor, was afterwards promoted to be King of Ning by his younger brother, the Emperor, in 718 A.D.- -six years after his accession.

Three of the other four Imperial princes who were sent to the Nestorian Monastery (as recorded in the Inscription) were brothers, and the fourth was their cousin.

That all five princes lived most harmoniously may be seen from the fact that they dwelt in a common residencea place built by the Emperor for them-where the Emperor himself may often have listened to the Nestorian missionaries.

The reign of Hsuian-Tsung, lasting over forty years, was the most glorious period in all Chinese history. Among others, the names of Madame Yang Kuei-fei (棋 妃) and An Lu-shan (安泉 山), the Cleopatra and MarkAntony of China, if the Emperor himself had been its Cæsar, are very familiar to us in Japan. In common parlance, the Emperor's attitude towards them much resembled that of the illustrious Khaliph Haroun Al-raschid toward Fetnah and Ganem, Love's Slave, as described in the Arabian Nights' Entertainments. 
The Inscription conveys the idea that the Emperor Hsüan-Tsung and his brothers were so sympathetic and so liberal toward the Nestorians that they restored the influence of the Luminous Religion. Hence we conclude that they were friends of the Syrian Missionaries, although whether the Emperor himself was a Christian or not we cannot determine.

A well-known anecdote says that one day Hsüan-Tsung lost his moustache whilst boiling a medicine for his, brother. He said: "I am only too willing to lose my moustache if my brother gets better."

This shows how different he was from the average Oriental monarchs of the time. He was humble and kindhearted.

(64) The early part of the period of T'ien-pao.-This began with the thirtieth year of the Emperor Hsuian-Tsung's reign, the T'ien-pao period itself corresponding to 742-755 A.D. Kao Li-shih himself was made "Generalissimo of Cavalry" in 748 A.D. So "the early part of the T'ien-pao" in our Inscription must mean at least 748 A.D., i.e. the seventh year of T'ien-pao.

General Kao Li-shih was a eunuch, and had been employed in the palace since the time of the Empress Dowager $\mathrm{Wu}$. His more than ordinary ability and strength proved of great service to Hsuian-Tsung in defending his Imperial person from the dagger of an assassin, who almost succeeded in assassinating him in the palace yard. But for this eunuch the Emperor would have fallen a victim to his enemy.

Hsüan-Tsung was very grateful to the eunuch, and finally promoted him to be "the Great General of the Cavalry," the Commander of the Imperial Guards.

(65) The portraits of five Emperors. - The Emperor T'aiTsung had his own portrait painted on the monastery wall some time after 635 A.D. as mentioned in the Inscription. When Hsuian-Tsung ordered the "faitlful portraits of the 
five Emperors" to be carried there some time after 748 A.D., the old portrait of the Emperor T'ai-Tsung was probably still visible.

As there had been altogether six T'ang emperors, viz. (I) Kao-Tsu ; (2) T'ai-Tsung ; (3) Kao-Tsung ; (4) Chung-Tsung ; (5) Jui-Tsung ; and (6) Hsüan-Tsung himself, so most likely by "the five faithful portraits of the Emperors" were meant those of Hsïan-Tsung and his predecessors with the exception of the great T'ai-Tsung himself, whose portrait was already there. Now that five more portraits were added, the portraits of all the T'ang Emperors up to 755 A.D. were visible on the walls of the Nestorian Monastery at Ch'ang-an.

(66) We were in a position to hang on to the Imperial bow and sword in case the beard of the Dragon should be out of reach.-This is a most difficult portion of the Inscription, and the translators differ as may be seen from the following :

(Abbé Huc) "Thus we were able to seize the bow, the sword, and the moustaches of the Dragon, although he was far off."

(Wylie) "Although the Dragon's beard was then remote, their bows and swords were still within reach; while the solar horns sent forth their rays, and celestial visages seemed close at hand."

(Legge) "Although the Dragon's (i.e. Imperial) beard in them was too far off, yet the bow and sword could be touched with the hand; when the Sun's horns (i.e. rays) shed on them their light, the celestial countenances seemed to be within about a cubit (from the spectator)."

(Moule) "Though the Dragon's beard is far away the bow and sword may be touched; the horn of the sun diffuses light; the divine faces are not far distant."

We think that the author, Ching-ching (King-tsing), Adam, alludes here to the old tradition so well known amongst Chinese and Japanese scholars, that "about B.C. 3700 there 
came down a Dragon with a long beard to the Yellow Emperor (黃需). Mounting it, the Emperor ascended to Heaven. Seventy or more of his servants and court ladies accompanied him. Minor officials finding themselves unable to follow His Majesty to Heaven, they all clung to the beard of the Dragon. But alas! the beard was pulled out by their weight. Upon this, the Emperor kindly let down his own bow (and sword). Clinging to the bow (and sword) all wept bitterly."

This being the tradition handed down to us, the sentence in the Inscription must have been an allusion to the story. The Emperors, so august and so majestic, are beyond the reach of ordinary folk, yet ordinary folks may look up at the portraits of the Emperors on the monastery walls. As the minor officials of the olden time were permitted to hold the Imperial bow and sword, so the Nestorians are allowed to gaze upon the Imperial portraits. If " a cat may look at a king," then how much more so the Nestorians!

"The Sun's horn" is the usual expression for the stern and serious visage of the Imperial dignity, whilst the expression "celestial face" means the gracious and kind-hearted countenance of the Emperor. All these expressions support our view as to the allusion to the above-quoted tradition which was first pointed out by Diaz in his edition of the Inscription, 1644, fol. 45 .

(67) In the third year of T'ien-pao. - The Chinese ideograph for the "year" was first changed from "nien" (年) to "tsai" (輚) in 744 A.D. by an Imperial Decree. Observing this, the author of our Inscription used "tsai" (載) instead of “nien” (年).

This is one of the many internal evidences in favour of the genuineness of the Nestorian Stone. The third year of T'ien-pao corresponds to 744 A.D.

(68) There was a priest by the name of Chi-ho in the Kingdom of Ta-cli in. - The Chinese "Chi-ho" is pronounced "Gi-wa" in Japanese (which is simply the ancient T'ang 
pronunciation preserved to this day in the Island Empire), and may well be identified with "Giwargis," i.e. "George."

This "priest Chi-ho" must have been "Bishop George" who came from $\mathrm{Ta}-\mathrm{ch}$ 'in with a reinforcement of monks, having been encouraged by the news of the Mission's great success brought back by the Persian chief and Bishop Chi-lieh (Cyriacus) in 732 A.D.

(69) Priest P' $u$-lun. - This priest may be identified with one of the three "Ephraims" who are named in the Inscriptionone in the text, and two in the lists of priests inscribed in Syriac on the sides of the stone.

The Chinese characters used here for "P'u-lun" differ from those used for it in the list of priests on the sides of the Monument. In fact, each of the three "Ephraims" is designated by different Chinese characters. For the "P' $u$-lun" here the name in Syriac is not given, whilst the other two have the Syriac equivalent for the Chinese characters.

(70) The Hsing-ch'ing Palace.-This Palace was erected in 7 I4 A.D., owing to the proposal of the King (later King of Ning) and four other Imperial Princes that they should have a residence near the Imperial Palace. So it was built in the Hsing-ch'ing Ward, on the left side of the city facing towards the Imperial Palace. This Hsing-ch'ing Palace was so near the Imperial Palace that the Emperor could go there direct through "The Luminous Wind Gate" of the Imperial Palace without being seen by the crowd.

It is also written in the Chinese contemporary Annals : "The Emperor Hsuan-Tsung ploughs the field in person at the back of the Hsing-ch'ing Palace so that he may cultivate sympathy with the farmers."

This Hsing-ch'ing Palace, the residence of the five Princes, was, therefore, a suitable place for the religious service mentioned in the Inscription.

(7 I) Monastery names composed and written by the Emperor -It is a well-known fact that nearly every monastery in China 
and Japan has two names-one called "the Mountain title" and the other "the Monastery name." "So-and-so Shan" (何 々 U), and “So-and-so Ssŭ” Monastery（何々寺） is the regular formula to designate a Buddhist temple. If our Nestorian Monastery enjoyed the great privilege of being a state Church, it must have had its "Shan name or Mountain name," beside its' Ssŭ name or monastery name, which was "Ta-ch'in Ssŭ." Although we cannot ascertain the "Mountain name" borne by our Nestorian Monastery, yet these words in the Inscription prove that it was under Imperial patronage and so must probably have possessed such a name.

(72) The Emperor Su-Tsung (756-762 A.D.).-He had been the Heir Apparent of Hsüan-Tsung for twenty years when the great rebellion of An Lu-shan (安鸪 山) occurred. He died in the seventy-eighth year of his age.

It was at a place called Ling-wu, which corresponds to Ling-chou in the prefecture of Ning-hsia in the province of Kan-su (甘麻省) that he ascended the throne in consequence of the whole Court having been suddenly compelled to quit the Capital because of the invading army of An Lu-shan. His father, the Emperor Hsüan-Tsung, survived the disaster but one year and died at Ch'êng-tu (成 都) in 756 A.D.

When the news that An Lu-shan had rebelled against the Emperor Hsuian-Tsung in 755 A.D. reached the King of the Uigurs (包鹃), he immediately sent his son, Yeh-hu (葉淁) (i.e. Jacob), at the head of four thousand picked men to defend the Imperial person from the arms of the rebels.

Prince Kuang-p'ing, the Errperor's own son, was made Commander-in-Chief, and Kuo Tzŭ-i (郭子 儀), of whom we have already spoken, had the command over the men of the Uigur tribes as well as over some other foreign mercenaries from the Western Lands.

The mere fact that some of the Nestorian monks were 
interpreters for the Chinese general who commanded the Uigur army is a sufficient proof that the "Luminous Religion" had already spread amongst the Uigurs.

Sir Aurel Stein, in "Ruins of Desert Cathay" (pub. 1912), describes his discovery of manuscripts in the Caves of the Thousand Buddhas at Tun-huang (数煌) on the westernmost frontier of China proper, which were in a Uigur script derived from Syriac. This Uigur script, he says, was "widely used among the Turkish population of Central Asia, before the spread of Mohammedanism, for the Turki writings."

(73) The Emperor Tai-Tsung.-He was a great friend and patron of the famous Indian monk Amogha-vajra, as were his father, Su-Tsung, and grandfather, Hsüan-Tsung. His reign corresponds to 763-779 A.D. Amogha-vajra died in 772 A.D. (see p. 136, supra). Our Ching-ching (採), the author of the Nestorian Inscription, must also have been a friend of this Emperor as well as of his successor Tê-Tsung. It is safe therefore to infer that he was intimate with Amoghavajra.

(74) The Birthday festival.-Huc, Wylie, Havret and others take this festival to be the birthday of the Messiah, but Dr. Legge rightly insisted that in this case the birthday of the Emperor was meant.

Compare the following different translations :

(Huc) "Every year, at the hour of the Nativity, he burnt celestial perfumes in remembrance of the divine benefit; he prepared imperial feasts to honour the Luminous Multitude."

(Wylie) "Always, on the Incarnation-day, he bestowed celestial incense and ordered the performance of a service of merit ; he distributed of the Imperial viands, in order to shed a glory on the Illustrious Congregation."

(Moule) "Every (year) on the day of the Nativity he presented divine incense to proclaim the perfected work; 
and offered a royal feast to do honour to the Christian Congregation."

(Legge) "Always when the day of his birth recurred, he contributed celestial incense wherewith to announce the meritorious deeds accomplished by him, and sent provisions from his own table to brighten our Illustrious Assembly."

In Nien Ch'ang's "Biographical History of Buddhism" (佛祖歴代通载) (xiv. p. 18) it is recorded that TaiTsung also had a service performed for him by a large company of Buddhist priests on his own birthday.

It is the more curious because the same phraseology in our text is found there too. (Cf. Legge, op. cit., p. 19.) But the explanation is that the Emperor was equally kind and sympathetic to Mohammedans, Manicheans and Buddhists as well as to our Nestorians. He allowed himself to write "the signboard" for a mosque, whilst it was he who gave Amogha-vajra the posthumous honour of "Prime Minister of the Empire," the highest honour that any one could receive in China.

Moreover, the observation of the Imperial birthday was instituted as a national holiday in 729 A.D. Known at first as "Ch'ien-ch'iu chieh" (千秋節), “The Thousand-AutumnFestival," it was afterwards changed to " $T$ 'ien-ch'ang-chieh" (天長節), “The Heaven-Endures-Festival." The latter name was, no doubt, borrowed from "Tao-tê-ching," "The Book of Morals," by Lao-tzŭ : "As long as Heaven endures and the Earth lasts"-T'ien ch'ang Ti chiu (天長地久).

This festival was first introduced into Japan in 775 A.D. as "T'ien-ch'ang-chieh" (Ten-cho-setsu) (天長節), “The Heaven-Endure-Festival " or "The Emperor-live-long-feast," whilst the Empress' birthday is now known as "Ti-chiuchieh" (Chi-ku-setsu), "The Earth-Lasting-feast" which may be translated "The Mother-of-the-Nation-live-longFestival."

But natural as it is to celebrate the Imperial birthday by a national holiday, its origin in China may have been due to 
the Nestorians keeping "the Birthday Festival of Messiah"; and we have reasons for thinking that even the Japanese national holiday of Ten-cho-setsu (天長䈣) is indirectly traceable to a Christian source. (See p. 144, supra.)

It was only sixty-seven years after "the Birthday Festival" had been instituted in 729 A.D. that Chinese Confucianists were allowed to partake in the Festival Service conducted in the Palace. We read in the authentic History

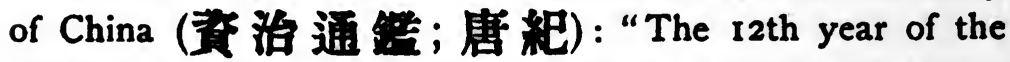

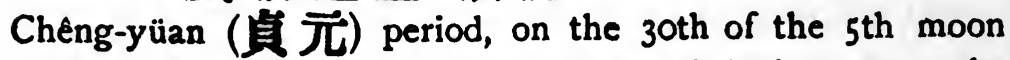
(796 A.D.), according to the long-established custom, the Buddhists and Taoists were invited to hold a religious service at the Ling-tê Palace. This year, Confucianists were admitted to join the party for the first time."

This shows that the Birthday Festival was not started by the Confucianists of the eighth century. We feel sure that it must have had its origin in the Assyrian Church in China which offered daily prayers for "the living as well as for the dead."

(75) Our present Emperor--This is, of course, the Emperor Te-Tsung who ascended the throne in 780 A.D., just one year before the erection of the Monument. According to Chinese etiquette it was not correct to call the Emperor by his personal name in his lifetime, so the author of the Inscription denotes the Emperor by the year-name "Chien-chung," and calls him "the Chien-chung Emperor," which year-name was chosen by the Emperor himself when he succeeded to the throne. Only after his death can an Emperor be called by his posthumous name which was, in this Emperor's case, Tê-Tsung, i.e. "the Virtuous Emperor." To every Emperor his posthumous name is given by his successor according to his merits and virtues.

(76) The eight objects of Government, etc.-According to Chinese Books on Government, the eight objects of Government are as follows: 
(I) Food-supply administration. The people's food precedes all else in politics.

(2) Wealth administration. This is to encourage the accumulation of wealth by thrift and avoidance of waste.

(3) Sacrifice and Festival administration. This is to show our gratitude to our Ancestors and thereby to strengthen the Unity of the Nation.

(4) Habitation administration. This is to look after the people's well-being in their homes.

(5) Educational administration. This is to look after the morals of the people.

(6) Penal administration. This is judicial administration. No civil laws in the modern sense were as yet developed.

(7) Foreign intercourse administration. How to treat the people of far and near was one of the most difficult problems of the Chinese government in all ages.

(8) Army administration. No navy had yet come within the horizon of a continental empire like China.

These "Eight objects" form the third division of what were called "The Nine Divisions of the Grand scheme of Imperial Government," which may be roughly explained as follows :

(I) To look after the five elements of the Empire:
I. Water.
4. Gold.
2. Fire.
5. Earth.

3. Wood.

(2) To keep the five things of the nation correct:
I. Appearance.
4. Hearing.

2. Speech.

5. Thought.

3. Sight.

(3) To carry out the Eight Objects of Administration :

I. Food supply administration.

2. Wealth administration.

3. Sacrifice and Festival administration. 
4. Habitation administration.

5. Educational administration.

6. Penal law administration.

7. Foreign intercourse administration.

8. Army administration.

(4) To observe the five points concerning Time-record:
I. Year.
3. Day.
5. Calendar.
2. Month.
4. Stars.

(5) The Greatest Extreme, i.e. Establishing the Authority based on the Unsurpassed Way of Justice and Mercy.

(6) To cultivate the Three Virtues of the people:
I. Honesty.
2. Industry.
3. Long-suffering.

(7) To encourage Divination ; that is, to enquire the Will of Heaven in all things in a humble spirit.

(8) To read Signs : to watch rain and winds.

(9) To enjoy the Five Blessings, viz. :

I. To have a long life.

2. To possess great wealth.

3. To enjoy peace and tranquillity.

4. To be virtuous.

5. To die a natural death in a good old age.

(77) Our great Donor was the priest I-ssü, etc.-The Chinese characters for the "Ta-shih-chu," the great donor (大作主), are well-known characters among Buddhists. They stand for the Sanskrit "Danapati," which means either " to give" or " one who gives."

That Priest I-ssŭ (伊斯) was a Nestorian priest, whose Syriac name was perhaps "Isaac," is quite clear from the context as well as from other sources. He was a man of great power and influence in Civil as well as Military affairs. He possessed all the decorations and honours recorded here on the Nestorian Stone, but this is not unprecedented in Chinese history, especially during the T'ang Era.

The celebrated Japanese Abe-no-nakamaro (700-770 A.D.) held a very high official position in the Chinese Court, whilst, 
as the Inscription given at the end of this book shows, a Persian Prince was made General of the Chinese Army. Even amongst the monastic orders we have seen many instances of priests serving as soldiers or secular officials.

Priest Fa-chien (法 堅) of the Hsi-ming Monastery (西明寺), Ch'ang-an, was the chief staff-officer of the rebel army at the siege of Fêng-t'ien (奉 天), Hsi-an, in 783 A.D. It was this $\mathrm{Fa}$-chien who introduced into China the use of "Turris Ambulatoria," "Testudo Arictaria," and "Testudo," and some other Roman military weapons a little before 783 A.D.

Again, the famous Priest Huai-i (懐 義) was an Imperial favourite and a great Military Commander under the Emperor Jui-Tsung. There were many warrior priests as well as civil officials amongst the Buddhist clergy both in China and Japan. The Priest I-ssŭ was no exception to the general tendency of the age.

Foreigners, especially those from Central Asia or Turkestan, were best fitted for such commands, because the Imperial army of China was then composed of mercenaries from the Uigur and other tribes. It was an army of all races and tongues with different creeds. So the most important thing for the General was to understand the various languages employed in it. Even the Commander-in-Chief, General Kuo Tzŭ-i(郭子儀), to whom our priest Isaac was attached by the Emperor's special wish, was a man of foreign extraction and a great master of foreign tongues.

(78) Chin-tzŭ-kuang-lu-ta-fu-Literally, "Minister of the Court of Imperial Entertainments, decorated with gold and purple." This was a title borne by civilian officials belonging to the upper grade of the third class in the hierarchy of Court distinctions. There were 9 classes and 30 grades in all.

(79) The city of the Royal residence.-There were at least two places known by the name of "the Royal City" (王舍城). The first was the royal residence of Magadha, 
a kingdom in central India. Rajagriha, "Royal City," was the first metropolis of Buddhism.

Of the second, we read in the famous "Buddhist Records of the Western World," by Hsiuan-tsang, the Chinese Pilgrim, in 629 A.D. He usually calls it "Little Rajagriha" (i.e. Royal City). This little Rajagriha is no less a place than the city of Balkh in Bactria, which is some 20 li in circumference. We think that "the Royal City" mentioned on the stone is this "Little Rajagriha," because in the Syriac part of the Inscription we find that many of the Nestorian priests came from Balkh.

It is not very difficult to imagine why the adjective "little" was dropped. Its omission before "Royal City" in this case was something like adding the adjective "great" before the name of the country, like "the Great T'ang" at the close of the Inscription.

It would have been a sacrifice on the author's-part to omit the important adjective "great" before the "great Donor," or "great T'ang," or "great Yesumband." But in the case of "Rajagriha," the author attained his purpose of glorifying the city by simply dropping the prefix "little." He could not call Balkh the "great Rajagriha," because the title belonged to the Royal City in Magadha.

In the year 802 A.D. a merchant named Isaac, the Jew, took an elephant, the sacred beast of Buddhism, across the Alps to Charlemagne as a gift from the Khaliph of Baghdad Haroun Al-Raschid (786-809 A.D.). The Nestorian Patriarch, Timothy I., was a great friend of the latter.

The context: "From far, from the City of the Royal Palace, he happened to come to the Middle Kingdom," shows us that the Nestorian priest Isaac came to China by land. He must have been a good and capable man. Above all he must have been a great master of languages. Who knows whether this Isaac was not the same Isaac as he who took the elephant to Charlemagne at the Court of Aix-la-Chapelle? 
(80) The Three Dynasties.—Hsia (夏) 2205 B.C., Shang (商) I766 B.C., and Chou (周) II 22 B.C., are called "the Three Dynasties." The civilization and refinement of the T'ang rivals those of "the Three Dynasties." That is to say, when this Priest Isaac arrived, China was so advanced and enlightened that she was not unworthy to welcome such a saintly man together with his companions.

(81) First performing certain faithful service to "the Red Court."-The "Red Court" or "Vermilion Court" may mean the Imperial Palace of T'ang. Dr. Wells Williams was entirely correct in saying that "the Red Court" means the Imperial Palace, especially the private or interior apartments.

It was in 724 A.D., that vermilion painting and redcoloured tiles, then so fashionable in China, were introduced at Nara, the capital of Japan. And in 768 A.D., the Kasuga Shrine at Nara was first painted in the vermilion colour, which we still see there, and the camphor-wood torii or gate at the Itsukushima Shrine which Kobo-daishi on his return from Ch'ang-an changed into its present Ryobu-Shinto form is also a brilliant vermilion.

(82) Finally, he inscribed his name in the Imperial book, etc. - This means that I-ssú (i.e. Isaac) became a loyal servant to His Imperial Majesty and paid him court.

To-day the visitors to the Court, if they hold official rank, inscribe their names in a book, which is presented to His Imperial Majesty afterwards for his inspection.

(83) Kuo Tzu-i, a Secretary of State, and Viceroy of Fênyang province.-He died in 782 A.D., a year after the erection of our Monument. He was one of the ablest' Commanders of the T'ang Era, and held the highest posts during the reigns of Hsüan-Tsung, Su-Tsung, Tai-Tsung, and TêTsung.

He was given the command over the Northern region by Hsiian-Tsung in 756 A.D. He was again appointed to the 
same post in 762 A.D. after having been displaced by the famous Li Kuang-pi (李光㟲) in 760 A.D.

General Kuo Tzŭ-i was very popular amongst the Uigur tribes. A story is told of how the Uigur soldiers when on the verge of revolt were pacified by him when they saw him appearing on horseback. They all smiled, and laying down their arms at his feet became the most loyal servants of the T'ang government.

But if the Priest Isaac accompanied General Kuo Tzŭ-i to the North (as the Nestorian Inscription says), he could not have done so as Vice-commander of the Army in 756 A.D., because Ko Shu-han (哥舒翰), another famous foreigner, was then Vice-commander and was taken prisoner after the disastrous battle.

The title of Vice-commander given to our Priest Isaac in the Inscription must therefore be ex post facto. We are inclined to think that he succeeded the unfortunate Ko Shuhan, and if so, he would have accompanied, as the Inscription says, General Kuo Tzŭ-i in his second expedition to the North in 762 A.D.

Isaac, like his predecessor Ko Shu-han, must above all have boen a great master of the Uigur language, for he had several thousand Uigur mercenaries under him.

(84) P'o-li (頗黎). - The Chinese P'o-li is the English "Crystal," and is used here for the Sanskrit "Sphatika," which is explained by "white pearl" or "water crystal." This and other objects mentioned in the Text were all objets de vertu.

(85) Four monasteries. -The translators differ in their rendering of this phrase:

(Huc) "Every year he assembled the religious and faithful from the four temples."

(Wylie) "Every year he assembled those in the sacred office from four Churches."

(Legge) "Every year he assembled the priests of all the monasteries. 
(Moule) "Every year he gathered the priests and novices of all the monasteries."

Dr. Legge suggests in a footnote that this might be translated "the monasteries of the four quarters" instead of "all the monasteries" given by himself. But we are rather inclined to think that this expression means "the four monasteries" that existed in Ch'ang-an at that time. Only the names of three Nestorian Churches out of "the four Churches" are known to us, one in the I-ning Ward which was built in 638 A.D. by the Emperor T'ai-Tsung's orders ; another, in the $\mathrm{Li}$-ch'üan Ward, built in 677 A.D. by the three brothers Firus (卑路斯) who were fugitive Princes from Persia and received shelter in China; and another in the Pu-chêng Ward, which was built about 708 A.D.

Thus far, we have failed to find the fourth, but it must have been somewhere on the left-hand side of the city facing the Imperial Court, because the first two were on the righthand side, whilst the third was on the left of the Capital.

(86) Ta-so (Dasa).-M. Pauthier thinks that this word is the Chinese corruption of "Dasarhas," a Sanskrit term which denotes "Buddha" or "Buddhist." Dr. G. Schlegel tried to identify it with the Persian "Tarsa" which means "fearer of God," and might have been used to denote "Christian."

We believe the word to be Sanskrit. "Ta-so" is the Sanskrit "Dasa," which means "Servant." For instance, Shomu Tenno, one of the Emperors of Japan, was an earnest Buddhist and humble enough to call himself "Sam-po-no-do" (三空奴), “Triratna-Dasa," which means " the Servant of the Three Precious Ones"-lit. "the preciousness of Buddha, the Law, and the Priesthood."

Again, the Sanskrit name "Chandra-dasa" means "the Servant of the Moon," whilst "Arya-dasa," which literally means "holy servant," is the name of a famous representative of the Mahasamghikha School.

Compare the following different translations : 
(Huc) "It has not been heard that there existed anything finer among the Ta-so, of pure duty, the religious men of the Luminous Doctrine, clothed in their white robes."

(Wylie) Even among the most pure and self-denying of the Buddhists, such excellence was never heard of; the white-clad members of the Illustrious Congregation, now considering these men, have desired to engrave a broad Tablet," etc.

(Legge) "Among the purest and most self-denying Buddhists, such excellence was never heard of; but now the white-stoled members of the Illustrious Religion see it in this man."

(Moule) "Ta-so of pure integrity had not so fair a reputation; the white-robed Christian doctor is now seen to be the perfect man."

We think Dr. Legge's rendering is the best with the exception of "Ta-sa," and the meaning of "White-robed," for "Ta-sa" means "the Servant of the Lord, whilst "Whiterobed" means (according to the best Chinese authority) "the laity" or "a layman." There is no need to suppose that "White-robed " means "wearing a surplice."

(87) Our Land of Tang.-The Chinese character "yen" (言) means "here " or "hereby," as in classical Chinese is often the case. It does not mean "I say." Compare the following different translations :

(Huc) "The Luminous religion entered the Empire under the dynasty of T'ang."

(Wylie) "When the pure, bright Illustrious Religion, Was introduced to our T'ang dynasty," etc.

(Legge) "Our brightest Truth then came to T'ang."

(Moule) "The Christian religion shining bright came, I say, to our house of T'ang."

(88) Ning-shu.-This name literally means " Peace-mercy," and is really the Chinese name for Hanan-ishu, the Patriarch who succeeded the Patriarch Jacob, and was consecrated 
Catholicos of the Assyrian Church at Baghdad in 774 A.D. (see pp. 35 and 36 ).

What Dr. William Wright wrote about Timothy in his excellent work, "A Short History of Syriac Literature," throws a side-light which explains why in the early part of 78I A.D. the Nestorians in China had "Hanan-ishu" as the reigning Patriarch of the Assyrian Church in this Inscription. He says (pp. 19I-192):

"Timothy I. was a native of Hazza in Hedhai-yabh and had been a pupil of Abraham bar Dashandadh at the school of Bashush in Sphsaph. He became bishop of Beth Baghesh, and stood well with the Muhammadan Governor of Mosul, Abu Musa ibu Musab, and his Christian secretary Abu Nuh al-Anbari.

"On the death of Hanan-Ishu II., in 779 A.D., several persons presented themselves as candidates for the dignity of Catholicos. Timothy got rid of Isho-yabh, abbot of Beth Abhe, by pointing out to him that he was an old man, unfit to withstand his younger rivals, and by promising, if he himself were successful, to make him metropolitan of Hedhaiyabh, which he afterwards did.

"Meantime Thomas of Kashar and other bishops held a Synod at the Convent of Mar Pethion in Bagdad, and elected the monk George, who had the support of Isa, the Court physician; but his formidable opponent died suddenly.

"Having by a mean trick attained the support of the Archdeacon Beroe and the heads of the various colleges, Timothy managed at last to get himself appointed Catholicos, about eight months after the death of his predecessor.

"He still, however, encountered strong opposition, Ephraim, metropolitan of Gunde-Shabhor; Solomon, bishop of AlHadithah; Joseph, metropolitan of Maru or Merv ; Sergius, bishop of Maallethaya, and others held a Synod at the Convent of Beth Hale, in which they made Rustam, bishop of Henaitha, metropolitan of Hedhaiyabh in place of Isho-yabha, and 
excommunicated Timothy, who retorted with the same weapon and deposed Joseph of Merv.

"Joseph brought the matter before Caliph al-Mahadi, but, failing to gain any redress, in an evil hour for himself became a Muhammadan. Once more Ephraim summoned his bishops to Bagdad and excommunicated Timothy for the second time, with no other result than counter-excommunication and some disgraceful rioting, which led to the interference of Isa and the restoration of peace.

"Timothy was duly installed in May, 780 A.D. He made the Bishop of Persia subject to the See of Seleucia, and appointed over them one Simeon as Metropolitan with orders to enforce a stricter Rule than heretofore.

"In his days Christianity spread among the Turks, and the Khakan himself is said to have become a convert. Timothy's disgraceful response to the Caliph al-Rashid in the matter of the divorce of Zubaidah may be seen in B.O. III., p. 161. He is said to have died in 204 A.H. (819-820 A.D.) or 205 A.H. (820-82I A.D.); but if he was Catholicos for forty-three years, his death cannot have taken place till 823 A.D."

But, in "The Book of Governors" (Vol. I., p. III), Dr. Budge says: "Here (at Nineveh) Isho-yabh lived until he became an old man, and he performed the episcopal office with such success that on the death of Henan-Isho II., who sat from 774-780, the Bishops and Metropolitans made all arrangement to elect him to the Patriarchate."

Again (Vol. II., p. 379) : "Hanan-Ishu II., who succeeded Mar Jacob as Nestorian Patriarch, A.Gr. 1085, A.D. 774, A.H. 157 ; he died A.D. 780."

If Hanan-Ishu died in 780 A.D. (as said by Dr. Budge), the installation of Timothy must have been in May, 781 A.D., instead of May, 780 A.D., because, as Dr. Wright says, there was a lapse of eight months between the death of Hanan-Ishu and the installation of Timothy. 
Both Dr. Wright and Dr. Budge reffer to the same authority, Assemanni, "Bibliotheca Orientalis." But Oriental writers being sparing in their use of dates, the two English writers differ in their conclusions.

The date given in our Monument in China supports Dr. Budge ; and Sir Aurel Stein has pointed out the exceeding accuracy of all Chinese historical dates. The death of Hanan-Ishu probably occurred in October, 780 A.D., but the distance and disorder combined were enough to prevent the news from reaching China.

(89) The great Yao-sên-zeen day.-We think that Mr. Wylie's identification of this with the Persian "Yaksamba," i.e. "the first day of the week" is correct, although Dr. Heller suggests that the word may be "Ho-samba," which is the Syriac for "the first day." He says that the day was the Sunday before one of the annual feasts and so might have been called "great." But as "Yao-sên-wên "' is also found in a Buddhist book on Astronomy (宿 曜 經) which came to China about the same time by way of Persia, we are satisfied with Mr. Wylie's identification. The 4th of February, 781 A.D. was the Sunday no doubt.

(90) Written by Lü Hsiul-yen, Assistant-secretary of State and Superintendent of the Civil Engineering Bureau of T'ai-chou. -None of the writers, whether native or foreign, on the Nestorian Inscription have thus far succeeded in tracing the identity of this Chinaman, Lü Hsiu-yen.

Great Chinese scholars like Mr. Wylie, Dr. Legge, M. Pauthier, and others have all failed to discover who and what was this somewhat mysterious calligrapher-a calligrapher of the first class during the $T$ 'ang Era, and yet unknown to the Chinese scholars who wrote books on "Metals and Stones."

The Chinese critics of the Inscription, like Yang Hsiang-fu (楊襄甫 or 楊㮡鉣) who wrote a book called "A Critical Study of the Nestorian Inscription" (贯敎碑文紀事改正), and Mr. Ch'ien (錢大昕) 
who wrote a book called "Some Considerations on the Nestorian Inscription"(杲教洘), have all left the problem of Lü Hsiu-yen unsolved.

Even in that most thorough-going and painstaking work of Père Henri Havret, S.J.- " La Stèle chrétienne de Si-nganfou " (pub. at Shanghai, 1897)-only one or two references are made to $L_{i i}$ Hsiu-yen, the Chinaman, and that very indirectly, so that this important question-a question which involves the greatest consequences-is left as dark as ever.

After devoting over ten pages (pp. 198-219) of the second volume of his work to the discussion of the different styles of handwriting, Pere Havret only succeeded in showing European scholars how well the writing on the Nestorian Stone could be compared with that of the famous calligraphers of the T'ang Era, between 632 A.D. and 84I A.D., but he said nothing about Lü Hsiu-yen himself, except to charge him (most unjustly, as we think) with having omitted one character after "the twenty-four sages" in the Inscription.

Père Havret says: "C'était sans doute 聖人 ou quelque chose d'analogue, que le prêtre 贯淨 avait écrit; Lin-sieouyen a omis le second caractère, et si l'on s'en aperçut avant de confier la pierre au sculpteur en lettres, on n'osa lui faire recommencer son travail " (p. 214). We have already said in our Note 18 that the Chinese writer did not omit the character unfonsciously.

We cannot but feel that our identification of this Lü Hsiuyen (呂 秀 偻) with the famous Lii Yen, a poet and calligrapher as well as the originator of the Chin-tan Chiao (The Religion of the Pills of Immortality) is correct, according to reasons given in the Introduction (pp. 49-54, supra).

This Lü Hsiu-yen was not a military man. His official duties were wholly civilian, but strange to say almost all translators treat him as if he had been a military man. Compare the following translations:

(Huc) "Liu-siou-yen, councillor of the Palace, and 
previously member of the Council of War, himself traced these characters."

(Wylie) "Written by Lew Sew-yen, Secretary to the Council, formerly Military superintendent for Tae-chow."

(Legge) "Written out by Lü Hsiu-yen, Secretary of State, formerly discharging the duties of military superintendent in T'ai-chau."

(Moule) "The Secretary of the Imperial Council who formerly occupied the post of Military Superintendent at T'ai-chou."

The Chinese title (胡識師前行) is not an official one. It denotes a Court Rank corresponding to the Lower Sixth Rank of the T'ang, whilst "T'ai-chou Ssŭ-shih-ts'anchün” (台州司士軍) is not a military office at all (see Introduction, p. 57).

Strange to say, this 朝議即前行 is misunderstood in all the works on the Inscription I have come across. The foreign translators, of course, must have had the very best Chinese scholars to consult with, but somehow they all made, to our great regret, this serious mistake. 朝議期前行 is one title whilst 朝議期 is another. 前行 is a part of the title. It does not belong to 台州司士軍 at all. The best book to be referred to is 大唐六典.

If our identification of this Lï Hsiu-yen with the famous Lui Yen is correct, then we can easily explain why the style of the Nestorian Inscription resembles those of the schools of Ch'u Sui-liang (猪遂良) and Ou-yang Hsün (陽淂詢), and why his official, if not social, position was not so high as that of the two above-mentioned men, whilst his calligraphical excellence and merit, judged by modern standards, can rank as high as that of any of the eighthcentury calligraphers. The writer Lü Hsiu-yen was only twenty-five years old when he wrote the Inscription for Ching-ching (景淨), Adam, who composed the Nestorian Inscription. 
(91) Kumdan and Saragh. - The identification of these two names is another very difficult problem in the study of the Nestorian Stone. No one as yet has succeeded in the identification of "Saragh," whilst many have failed to explain why the Western Asiatics of the Middle Ages called the Chinese Capital—or, more correctly speaking, the part of China where the Capital is situated-Kumdan.

Sir Henry Yule says: "Khumdan was the name given by the Turkish and Western Asiatic nations to the city of Ch'angan, now represented by Singanfu in Shensi, which was the capital of several Chinese dynasties between the twelfth century B.C. and the ninth century A.D. The name Khumdan appears in the Syriac part of the Singanfu Inscription repeatedly; in the Arab Relations of the ninth century published by Renaudot and by Reinaud; in Masudi; in Edrisi (as the name of the great river of China); and in Abulfeda. Pauthier takes Khumdan for a Western transcription of Ch'angan, whilst Neumann regards it as a corruption of Kong-tien, Court or Palace. Both of these explanations seem unsatisfactory" ("Cathay and the Way Thither," Vol I., p. 5 I).

We think "Kumdan" is the old pronunciation of Kuannei (關內). We have in Japanese "Kan-dai" for the same Chinese characters and with the same meaning. The Japanese received the sound "dai" (内) for the modern Chinese "nei" (內) from the Chinese of the T'ang period twelve hundred years ago. So we may fairly say that our "Kan-dai" is the nearest approach to the old Chinese pronunciation of the modern "Kuan-nei" (see p. 222, supra).

"Kan" or "Kuan" (關) means "citadel" or "gate," whilst "dai" or " nei" (䒘) means "inside" or "within." Hence "Kumdan" or "Kan-dai" literally means "Inside the Citadels." The Imperial province in which the Capital was located, and well protected by many citadels was called " Kandai" or "Chi-nei" (幾 內) in China as well as in Japan. 
Whether our explanation of the word "Kumdan" would have satisfied Sir Henry Yule and others we know not, but the old sound of the Chinese characters as preserved in Japanese compels us to say that the word "Khumdan" or "Kumdan" must be a corruption of the "Kan-dai" or "Kuan-nei" - within the "citadels" or "inside of the forts" of the Central Province.

So much for the identification of "Kumdan," now for the identification of "Saragh."

Sir Henry Yule says: "Saragh, it may be added, is referred by Pauthier to the Saragh of Ptolemy, a city placed by the geographer among the Sinae, and, according to his theory, of course, far to the south of the real position of Lo-yang. But we have seen reason to believe that Ptolemy's view of the Sinae and Seres is that of a person using his right and left eye separately. Binocular vision reduces the two objects to one, and corrects their displacements."

Again, referring to the word "Seric," Sir Henry says, "I do not know what town the author can allude to, but see the Siurhia of Moses the Armenian, and the Saragh of the Singan-fu Inscription."

We wish that it were possible to identify "Saragh" with the well-known city of Lo-yang, in the Province of Honan, but all the evidences are against it.

Lo-yang was originally called Chou-nan (周 南), but ever since the time of the Han (206 B.C.) it has kept its name of Lo-yang.

Again, Lo-yang was never known as a decidedly Nestorian city either in the Chinese books or in the Nestorian Inscription itself. It is not mentioned in the map attached to Sir Henry Yule's book, "Cathay and the Way Thither," which shows the Metropolitan Sees of the Nestorian Church and some of the Latin missionary bishoprics of the fourteenth century A.D.

We are inclined to identify "Saragh" with Sarakhs in 
the Persian province of Khorassan, for "Shahrakhs," "Cherakhs," and "Serakhs," mean the same thing. We are told that the name "Shahrakhs" is derived from the two words "Shah" and "rauch " meaning the "King of the Day," whilst "Khorassan," the name of the Province where Shahrakhs was the most important city in the ancient time, means "The Region of the Sun." It was the most suitable name for the headquarters of "the Luminous Religion."

The origin of the name Khorassan is prettily suggested by Moore, at the commencement of his poem of Lalla Rookh-

"In the delightful province of the Sun, The first of Persian lands he shines upon."

This Persian Sharakhs was known to the Chinese for many centuries, and was familiar to them ever since their intercourse with Persians in the early centuries of the Christian era. “Sa-la-ha-hsi” (撒刺哈夕) and “Hsila-ssŭ” (者刺思) are two different.ways of transliteration the Chinese have for Shahrakhs.

According to certain authorities, it is now nothing but a settlement and fort in the Russian Transcaspian Territory, ninety miles" south-west of Merv, on the right bank of the river Tejen (Heri-Rud), which here, before losing itself in the sand of the desert, forms the boundary between the Russian dominions and the Persian province of Khorassan. At present (according to the 1910 Report by the British Authorities) it contains about 2000 people. On the opposite side of the river-nine miles away east-south-east-is the old Persian town of Sarakhs, now in ruins.

This old ruined town, we think, must have been the "Saragh" of the Nestorian Inscription.

How Khorassan with its great Nestorian city of Shahrakhs was related to China in former days can be seen from Sir Henry Yule's description in "Cathay and the Way Thither" 
(Vol. I., p. 88) of the intercourse between China and Persia. He says :

"In the days of Yang-ti of the Sui Dynasty $(605-617)$ China had begun to regain that influence over the states of Central Asia which it had enjoyed in the great days of the Han, preceding and following the Christian Era, and under T'ai-Tsung of the T'ang (627-650 A.D.) that influence was fully re-established and the frontiers of the Empire were again carried to the Bolor and even beyond it to the borders of Persia. In these remote provinces the actual administration remained in the hands of the native princes who acknowledged themselves the vassals of the Emperor. But from him they accepted investiture, Chinese seals of office, and decorations as lieges of the empire. Their states were divided after the Chinese manner into departments, districts, and cantons ( $f u$, chou, and hsien), each of which received a Chinese name by which it was entered in the Imperial registers; whilst tributary states west of the Bolor formed sixteen $f u$ and seventy-two cheu over which were distributed a hundred and twenty-six Chinese military posts. The lists of the sixteen districts of the first class has been published by Remusat, and though doubts attach to the localities of some, enough has been made out to show that this Chinese organization extended, at least in theory, over Ferghana and the country round Tashkand, over the eastern part at least of Mawaralnahr, the country on the Oxus from Balk upwards, Bamian and other districts adjoining the Hindu Kush, with perhaps Sejistan and part of Khorassan.

"The states of Turkestan and Khorassan were probably desirous to place themselves under Chinese protection in the vain hope of finding it a bulwark against the Saracen flood, and may themselves have originated this action of the Chinese Government."

Again, Sir Heniy says: "The existence of an episcopal see at Merv and Tus in 334 A.D., raised to Metropolitan 
dignity in 420 A.D., shows how early the church had established itself also in Khorassan."

We believe that "Saragh"-the modern Sarakhs-was a great see of the Nestorian Metropolitan at the time when our Assyrian Stone of Witness was set up in China.

How could the Priest Gabriel have been the Archdeacon and the Church "ruler" or "Head of the Church" of Kumdan and Saragh at the same time? Our explanation is this that the one title was official whilst the other was honorary. Gabriel enjoyed both titles as he must have been often to "Saragh" in order to represent the interests of the Nestorian Mission in China.

To-day, for example, an English missionary bishop in Japan acts in two capacities. He is an English bishop in the pay of a Missionary Society in London whilst at the same time he is, canonically speaking, a bishop of the Japanese Church.

(92) The Director of the Imperial Bureau, etc.-This Bureau which was restored in 704 A.D. was one of the very oldest institutions in Chinese history-so old that it dates back to almost pre-historic times.

The Han Dynasty had this Bureau as early as 200 B.C. Its organization of the Bureau is thus described in the old institutional works :

"One director with two assistants under him, looks after the ceremonies, music, festivals, sacrifices, and worship."

That this was a most important office from a religious point of view is quite clear, and that it should have been occupied by our Priest Yeh-li (i.e. Gabriel) shows how influential the Nestorians were at the time when the Buddhist Patriarch, Amogha-vajra, was all-powerful at the Chinese Court.

(93) The Head Priest of the Monastery.-This may mean "The Lord High Abbot," or "the Prior." The priest had great power and was appointed by the Imperial Government 
of the T'ang. The Empress-Dowager $\mathrm{Wu}$ once appointed her favourite priest Huai-i (懷 義) as Chief Priest of the "White-Horse" Monastery in 685 A.D.

The Head or Chief Priest of the monastery must have ranked as high as a Metropolitan or Bishop in China at that time.

(94) Balkh.-The capital of the ancient kingdom of Bactria or Zariaspa and situated on the right bank of the Adirsiah or Balkh River. The modern town, enclosed by a mud wall and having a citadel, occupies but a fraction of the surface embraced by the ancient city, the remains of which cover a space twenty miles in circumference, and comprises eighteen aqueducts, besides buildings of various ages, all in utter ruin. The antiquity and greatness of the place are recognized by the native population, who speak of it as "the Mother of Cities." At a very early date, it was the rival of Ecbatana, Nineveh, and Babylon, and is said to have dated back to Nimrod. For a long time the city and country was the central seat of the Zoroastrian religion; Zoroaster himself is said to have died within its walls.

From the Hsi yü chi (大唐西域記) of Hsüan-tsang, a Chinese Pilgrim, we learn that in his time in the seventh, century $(653-646$ A.D.), there were in Balkh, or its vicinity, about a hundred Buddhist convents, with 3000 devotees, and that there was a large number of stupas and other religious monuments.

There were several important trade-routes from Balkh, stretching as far as India and China, and the city itself was of a cosmopolitan nature in the Middle Ages.

In 1220 Genghis Khan sacked the venerable city, butchered its inhabitants, and levelled all the buildings; but Marco Polo describes it "as a noble city and a great," although it was far greater in former days. But the Tartars and other nations have greatly ravaged and destroyed it. There were formerly many fine palaces and buildings of 
marble, and the ruins of them still remain. The people of the city state that it was here that "Alexander took to wife the daughter of Darius." ("Travels of Marco Polo," by Sir Henry Yule, p. 158 .)

In 1348 , Timur completed the work of devastation which Genghis Khan and others had left undone.

Again, the city of Balkh, we are told, formed the seat of the government of Aurungzeb in his youth.

In 1736 it was conquered by Nadir Shah. Under the Durani monarchy, it fell into the hands of the A fghans. It was conquered by Shah Murad of Kurduz i: 1820, and for some time past has been subject to che Khar of Bokhara.

(95) Shiang-thsua. This word is very difficult to identify. Assemanni has, as we are told by Prof. Margoliuth, "Sinastan" (i.e. China) for it. But this identification cannot be accepted since in another part of the Inscription the name "Zhinastan" is used to represent China.

Dr. Heller thinks (1897) that the word "Shiangatsuo," as he has it, is "Hsiang-chu " (叚主), i.e. " country-lord," the Chinese translation of "Chorepiscopos."

We wish this were so! But neither in Buddhist terminology nor Taoist phraseology do we come across such a word as "Hsiang-chu" (哏主).

If we grant that the word "Hsiang-chu" did exist some twelve hundred years ago as an independent title for a Nestorian priest, we can find no reason why it should have been written only in the Syriac without a Chinese equivalent.

Would it not be more natural to find it written in Chinese rather than in Syriac, if it were the Chinese translation of the term "Chorepiscopos"?

For a long time we entertained the view that the word "Shiang-thsu" might be a Syriac form of the Chinese title of a bishop-"Shang-tso" (上 座), the word itself being 
the Chinese translation of the Sanskrit word "Sthavira," which means "Head of the local priesthood" or "Chairman of the Synod." But we have had to give up onr theory for the same reason that we found Dr. Heller's theory inacceptable, viz. that if it were the Chinese translation of "Chorepiscopos" or "Sthavira," it would have its equivalent in Chinese and not in Syriac.

If we compare the name and title of this chorepiscopos Mar Sergius with those of the other chorepiscopos mentioned in the Inscription, we see at once that "Shiang-thsua " is nothing more than a local name. The force of analogy compels us to think that it must be a name of the Nestorian district in China.

Mar Yesbuzid, who erected the Nestorian Stone, is mentioned as "priest and chorepiscopos of Kumdan, the Royal City."

Adam, the author of the Inscription, is designated as "priest and chorepiscopos and Papas of Zhinastan."

The two other bishops, Bishop John and Chorepiscopos Mar Sergius whose Chinese name was Hsing-t'ung (行 通), have no name of a see attached to them.

We are inclined to identify the word "Shiang-thsua" with a local name known to the Nestorians of the time-at least to the Persian missionaries in China-as that of a district of the Nestorian Church in China. It seems to us that, if Mar Yesbuzid was the chorepiscopos of Kumdan (as stated in the Inscription) he must have been bishop of the northwestern part of the modern province of Shensi; and that Mar Sergius, priest and chorepiscopos (of) Shiang-thsua must have been bishop of the south-eastern part of the same province. The south-eastern part of Shensi was commonly known as Hsi-an-tso (西安左) or Hsi-an-ch'ien (西安前), because it is in front of Hsi-an-fu, but its legal name during the early part of the T'ang Era was Hsi-an-chou (西安州), with the city of Hsing-an-fu as the head of the 
district. "Shiang-thsua" may be the foreign corruption of the local name.

In this Hsing-an-chou (興安州), there is to-day a famous “Shun-yang-kung”(純陽宫), a temple dedicated to the memory of the originator of "the Pills-of-ItnmortalityReligion" whose name is known as Lü Yen, but whom we identified with Lü Hsiu-yen, the Chinese scholar, who wrote the Inscription for its author Adam.

The Ta-Ch'ing-I-T'ung-Chih (大清一統志) says that "the old monastery site is in the south-eastern corner of the city. It is commonly known as 'Tzŭ-fei-tao-yüan' (紫屝道院), 'the Monastery of the Purple-Door' or the Purple Screen."

It is very strange that this "Lü Yen" relic should be preserved in this city. Is it not due to the fact that Lü Yen, i.e. Lü Hsiu-yen, was one of the most influential Christian converts, and that he founded the Chin-tan Chiao, "the Religion of the Pills of Immortality," that his relics were preserved in the old monastery, which, we think, must have been a Nestorian monastery in Hsing-an-chou?

If we read "Shiang-thsua" for "Shan-tso" (陝左), i.e. "the eastern district of Shen-si," we come to the same conclusion.

Finally, if we were to read "Shiang-thsua" for Shang-tu (.上都), i.e. "the Metropolis" or " the Capital," which was the common appellation of Hsi-an-fu at that time, we must conclude that the Bishop of Kumdan was Bishop of the north-western district of Shen-si, whilst the Bishop of Shiangthsua or Shang-tu would have been Bishop of the southwestern part of Shen-si with Shang-tu at the head of the district, and Hsing-an-fu is, of course, included within the district of Shiang-thsua. In any case we are inclined to identify this "Shiang-thsua" with the modern district of Hsing-an-fu (興安府), the old district of Hsi-an-chou (西安州). 


\section{APPENDIX I.}

(The following is the translation of the newly discovered inscription which can be seen in the Imperial Museum, Uyeno, Tokyo. The original stone belonged to the late Governor-general Tuan-fang (端 方), whose collections of "Metals and Stones" are well known. The rubbing itself is about 18 inches square and contains 306 Chinese letters. Only eighteen letters are illegible, the rest being quite clear.

This Inscription which is 72 years older than that on the Nestorian Stone settles the vexed question of " $A$-lo-pern." No one may maintain that "A-lo-han" in this Inscription is the Chinese corruption "Raban.")

"The Inscription on the Stone-tablet set up in memory of the late Great Persian Chieftain, the General and Commander of the Right Wings of the Imperial Army of T'ang (i.e. China) with the title of Grand Duke of Chin-ch'êng-chün (in Kan-su) and the Rank of Shang-chu-kuo (上柱 國), i.e. lit. 'The first-class Corner Stone of the Empire'):

This is the Stone-tablet erected in memory of A-lo-han (阿 羅喊), a Persian prince by birth and the most illustrious of the whole tribe. During the period of Hsien-ching (A.D. 656-661), the then reigning Emperor Kao-Tsung the Great, hearing of the meritorious service and illustrious deeds of this Persian prince sent a special messenger to invite him to his own palace (here are two illegible characters).

As soon as the Prince arrived at the capital, the Emperor appointed him Generalissimo, and charged him with the responsibility of defending the Northern Gate (i.e. the northern 
region of China)-(here is one illegible character) and sent him as the Imperial Envoy to the tribes of Tibet, Ephraim, and other countries.

On the western borders of Ephraim, he set up a stone monument which is still visible and is still preaching the essence of the Holy Teaching to the wild tribes; ever since all the surrounding countries (i.e. around the monument) have become very peaceful.

This is mainly due to the virtuous deeds and wise guidance of our great General, the Prince of Persia, who ruled over those peoples, and invited several foreign tribes to organize the Imperial Guards as well as the other Army Divisions. So his meritorious service to the country and its Rulers is manifold.

His name should be written for ever on the walls of

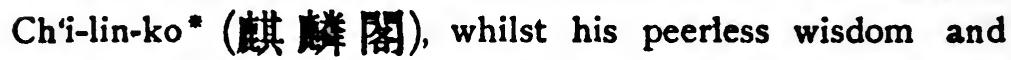
priceless talents are worthy of being inscribed on this stone. Surely his name should be numbered as one of the Faithful in the Yün-t'ai Hall $\dagger$ (雲呿閣).

On the Ist of the $4^{\text {th }}$ moon, the first year of the Chingyü Period (A.D. 7 10) at the age of ninety and five years, the Prince died suddenly at his own private residence in Ho-nan-fu.

O woeful day on which we lost this Great Prince, the Generalissimo and Leader of the Tribes! When he died, the wind that blew over the mountain-tops sighed more sorrowfully than ever! The sun that shines over us peered most drearily through the dark clouds! Even the birds refrained from singing on that sad day because of his death! How could we therefore restrain ourselves from shedding

- Ch'i-lin-ko is the name of an Inperial Palace Hall where the Chinese Emperor had the portraits of eleven illustrious men painted, in 5 I A.D., and is 2 Chinese Walhalla of the first century.

+ Yün-t'ai-ko is another Imperial Palace Hall where the Chinese Emperor had the portraits of thirty-two famous generals painted, and is a Chinese Pantheon of the third century. 
tears! The pine-tree suffers from the drought, and we feel the silence of the waterless fountain the harder to bear. So felt all who followed him to the grave on that sorrowful day. $\mathrm{O}$ woe betide the day!

On the ... (illegible) day of the month... (illegible), his son and heir Chü-lo (俱羅) (i.e. Gur) and his friends, weeping and lamenting most sincerely with ceaseless tears, and afterwards faithfully observing Spring and,Autumn Festivals every year, finally buried the Prince in the suburb outside the Chien-ch'un Gate, Ho-nan-fu, and made a small grave-mound so that his soul might rest in peace!"

(The names of neither the author nor the calligraphical writer of the Inscription are given.) 
The Syro-Chinese Text of the Nestorinn Inscription.

\section{大秦景教流行中国碑 \\ 景教流行中國碑頌讲序 \\ 大秦寺㑭景浄述}

- rdwelg

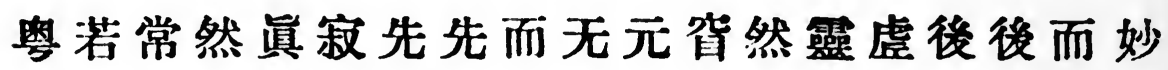

有紫立樞而造化妙衆聖以元煲者其唯我

三一妙身无元眞主阿羅訶验制十字以定四方

部元風而生二氣暗空易而天地開日月運而書

夜作匠成萬物然立初人別賜良和令鎮化海渾

元之性豦而不盈素薄之心本無希嗜泊乎奖殫

施安鈿飾純精閒平大於此是之中隟冥同於彼

非之內是以三百六十五種肩随結轍竞織法羅

或指物以託宗或空有以淪二或禧妧以邀福或

伐善以矯人智慮管營恩情役役范然無得煎迫

轉燒積棟亡途久迷休復於是 我三一分身

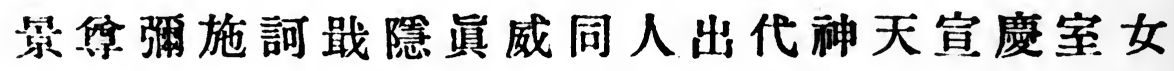

誕留於大秦景宿告群波斯酰耀以來貢圆廿四 翡有說之舊法理家國於大部設 三一淨風無 
言之新教陶良用於正信制入境之度鍊鹿成盁 啓三常之閏開生减死慗景日以破暗府魔安於 是乎悉摧棹慈航以登明宫含靈於是乎既濟能 事斯曅亭午昇眞經留甘七部張元化以發靈關 法浴水風涤浮華而潔虚白印持十字融四照以 合無拘擊木震仁惠之音東僼趣生策之路存影 所以有外行制頂所以。無內情不音喊獲均貴賤 於人不聚貨財示聱遗於我齊以伏識而成成以

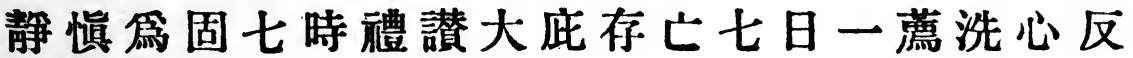
素䢐常之道妙而難名功用昭彰强稱景敎惟道 非聖不弘毠非道不大道聖符契天下文明太 宗文皇帝光華啓運明哇臨人大秦國有上德日 阿羅本占青雲而載眞經望風律以馳茂險貞觀

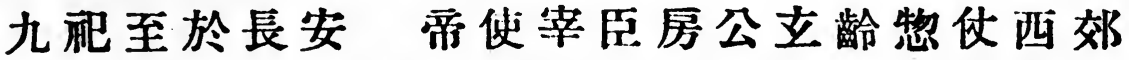
賓迎入內翻經書殿問道禁関哚知正眞特命傳 授貞觀十有二年秋七月詔日道無常名聖無常 體檤方設教密濟群生大秦國大德阿羅本遠將 經像來獻上京詳其教旨立妙無篇觀其元宗生 成立要詞無䌘說理有忘鉒濟物利人宜行天下 


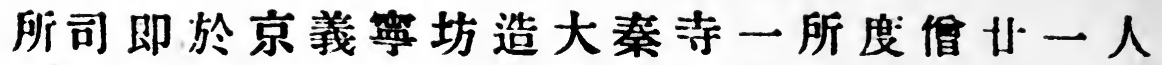
宗周德喪青駕西昇巨唐道光景風東扇旋令有

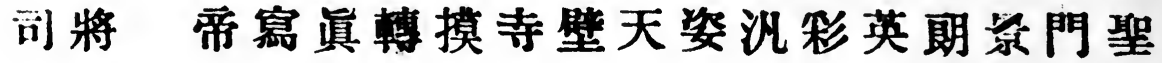
迹騰群永輝法界案西域圆記及漢魏史策大秦 國南統珊瑚之海北梅䍃窝之山西空仙境花林 東接長風哥水其土出火䋩布返魂香明月珠夜 光璧俗無窛盄人有樂麻法非景不行主非德不

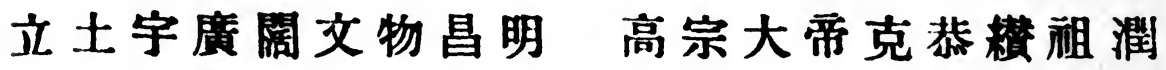

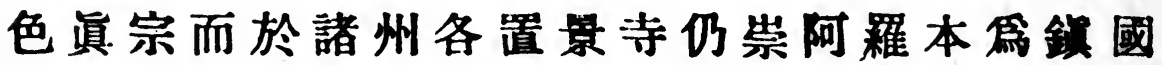
大法主法流十道國富元休寺滿百城家殷景砶 聖曆年程子用壯鵱口於果周先天末下士大笑 訕謗於西鎬有若僧首羅含大德及烈亚金方貴 緒物外高諙共振立網俱維絶紐立宗至道 皇帝合覀國等五王親臨稫宇建立壇場法棟整 橈而更崇道石時傾而復正天珼初命大將軍高 力士送五聖竄真寺內安置睗絹百匹奉虔 客圖龍踓遠弓劍可紮日角舒光天顔迟尺三 載大秦國有俈佶和贍星向化望日朝尊詔你羅 含侮普論等一七人與大德结和於興度宮修功 


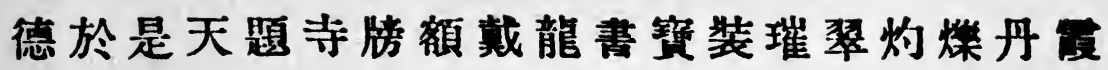

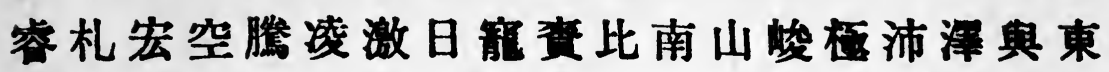
海齊深道無不可所可可名聖無不作所作可䢞

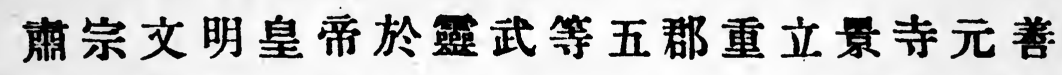

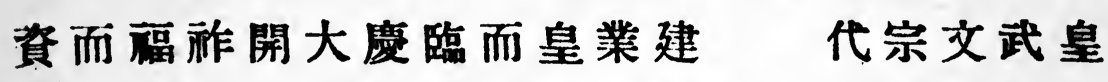
常恢張哇運從事無䨖每於降誕之辰錫天香以 告成功頒御潩以光景衆且乹以美利故能廣生 㕵以體元故能亭毒我建中聖神文武皇需 披入政以黚陟幽明閐九㷌以惟新景命化通立 理祝無愧心至於方大而虚專静而恕廣意救采 苦善貸被群生者我修行之大鿕汲引之階渐也 若使風雨時天下静人能理物能清存能昌沿能 樂念生算應情幦自誠者我景力能事之功用也 大施主金紫光称大夫同朔方唧度副使試殿中

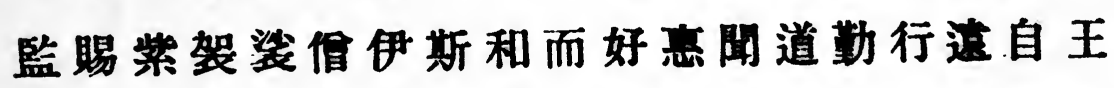
舍之城聿來中夏術高三代蕉博十全始効節於 丹庭乃策名於王帳中蓄命沼晹郡王郭公子儀

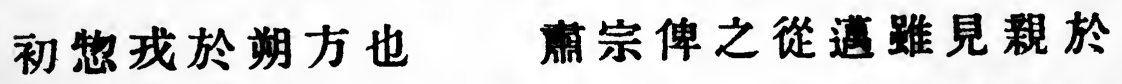
卧內不自異於行閒公公爪牙作需耳目能散秋 


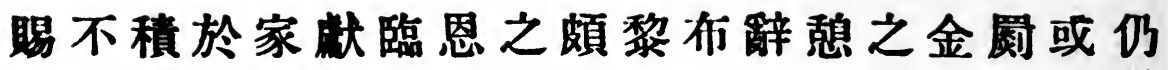
其舊寺或重廣法堂崇飾廊宇如窝斯飛更効景 門依仁施利每歳集四寺諙徒虔事精供俻諸五 旬餧者來而什之寒者來而衣之病者療而起之 死者葬而安之清節達奖未聞斯美白衣景士今 見其人願刻洪碑以掦休烈詞日面主无元 湛寂常然權奥匠化起地立天分身出代救度無 遗日昇暗減成證真立 赫赫文皇道冠前王 乘時投乹倣坤張明明景教言歸我唐翻經建 寺存歾舟航百福偕作萬邦之康亳宗纂祖 更築精宇和宮敞期温滿中土真道宣明式封法 主人有樂康物無灾苦立宗啓聖克修靵正 御䧛掦輝天書蔚映皇圖璀骤率土高敬庶積战 熙人賴其度舞宗來復天威引駕聖日舒昌 群風掃夜解歸皇室栊氛永謝止沸定塵造我區 夏代宗孝義德合天地開貸生成物資美利

香以埌功仁以作施暘谷來威月堀畢萃建

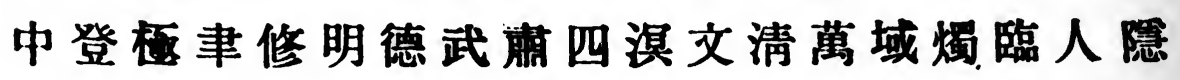
鏡制物色六合昭蘇百管取則道惟廣宂應惟密 


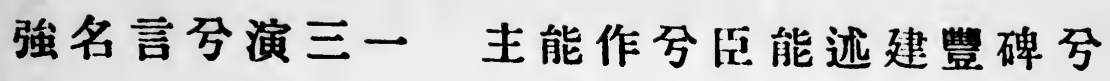
頌元吉

大唐建中二年葴在作哥太蔟月七日大耀森文 日建立時法主僧䆬恕知東方之景衆也

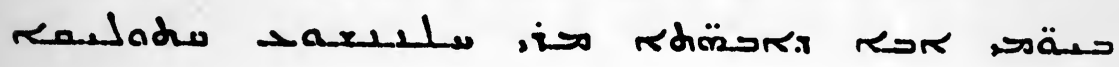
.. menitits

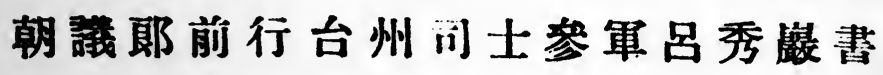

助捡校試太常卿盼紫袈裟寺主僧業利

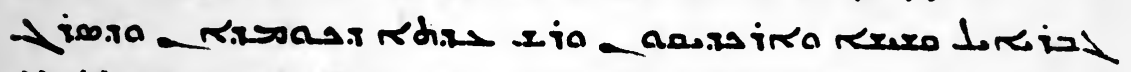

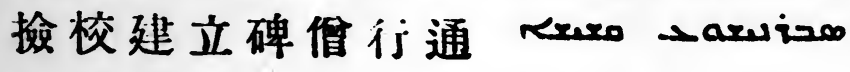

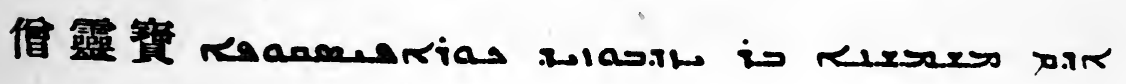

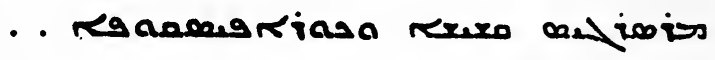
مdïo

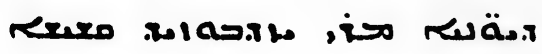
- r.roas racamariaso

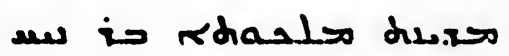

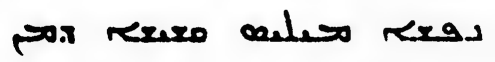

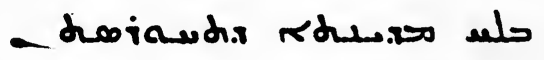
rares

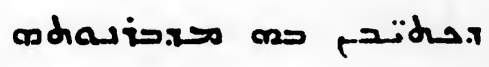
-acodaraina مarar תم . . 
On the left side.

Top rono.

形

㖮二 而 Reseo sacars

留 亚 مrenas

踝 searo 1.ren

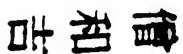
Reres artion

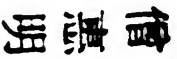

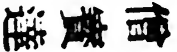

来蔽

* * *

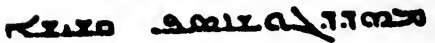

***

Rrexo siskenrso

Rera

reser wro

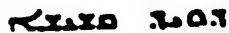

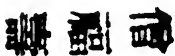

Reseo Reaso

Second ronv

淮政

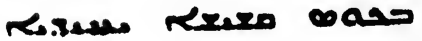

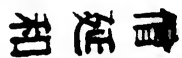

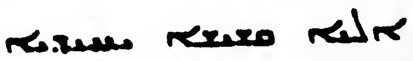

* * *

مiseno Rereso

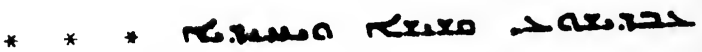

* * rizor resero a acer 
临

The third rowo.

각

1 ㄴํ

㳦 亚

证帮馬

路 㯒

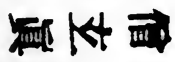

强门亚

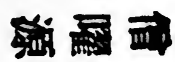

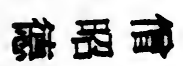

䍀奴亚

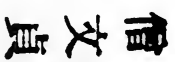

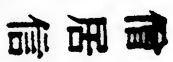

然为

Fourth ronv.

的些

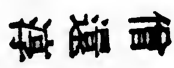

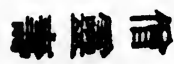

- aimo

onita

Sask

neal

dos

مare

orsenaro

مan

>arives

مaxaras

neal

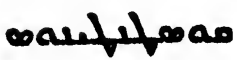

was

orenostar

مaw

Iask 


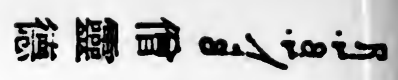

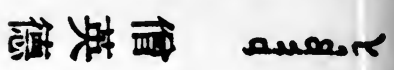

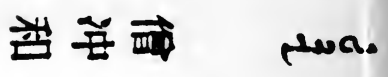

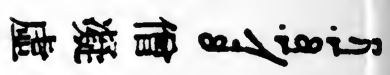

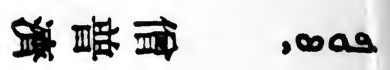

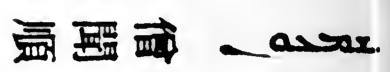
语 1 梊

(Words added by a visitor in $\mathrm{A}$. D. 1859.)

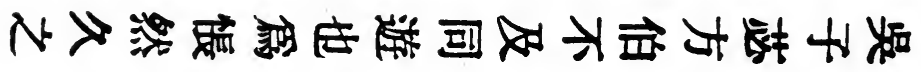

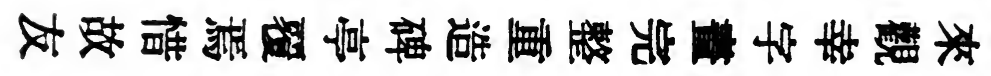

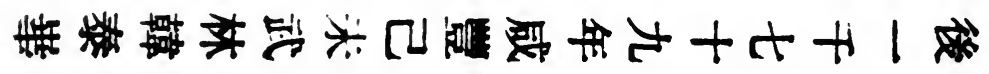


On the right side.

Top rove.

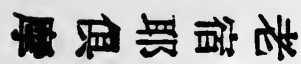

معans

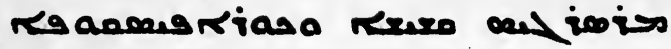

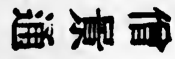

raopdyres

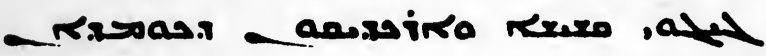

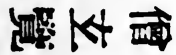

reriaso

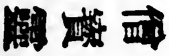

renes colas

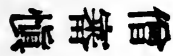

Reres arsar

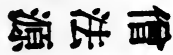

Rere vark

* 차 西

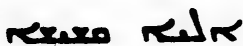

可造醉

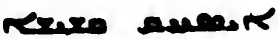

단 类 $\vec{m}$

مaw2 معere

些

مave

Second rovo.

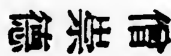

קaas مدar

总

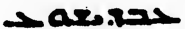

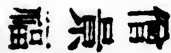

sxtars

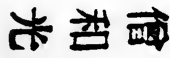

- 
融谋而

مa

酒 和

- لح مaver

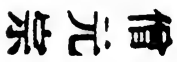

can

开些亚

-ascer

歌比亚

ron

敉

Rin

错牙

بarian

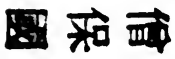

cas

1 포 패

1rousar

Third row.

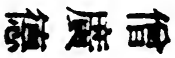

Intial

* * *

مa

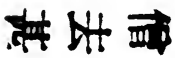

-asere

* * *

ramor

ज्ञात होता

rana 
Appendix No. II.

The original text of the Appendix No. I.

大唐故波斯國大余長右屯衛将軍上桂 國金城郡開國公波斯君丘之唋

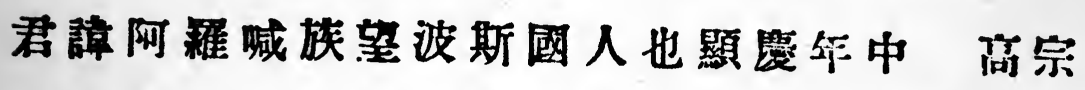
天皇大帝以功績有稱名聞 $\square \square$ 出使召隶至此

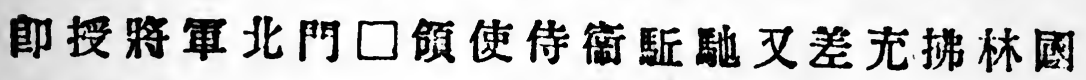

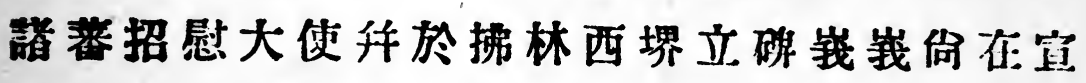

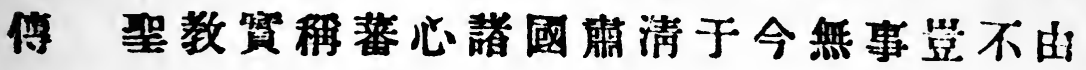

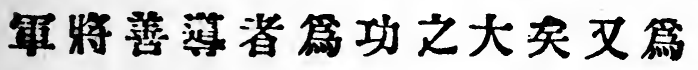

則天大聖皇后召諸蕃王建造天樞及諸軍立工。

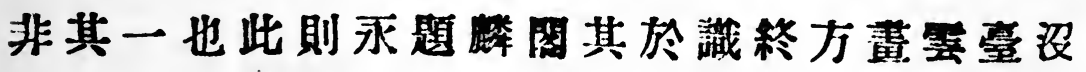
而須錄以景雲元年四月一日暴恰過踝春秋九

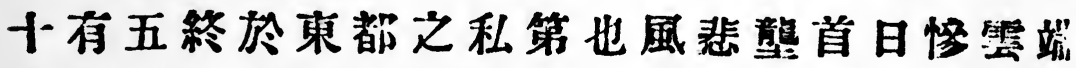

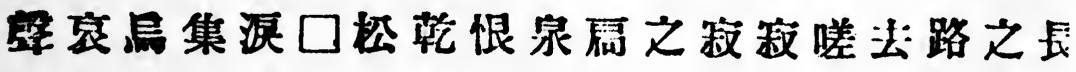
咾鳴呼衰哉以其年口月 $\square$ 日有子俱籍等躆天

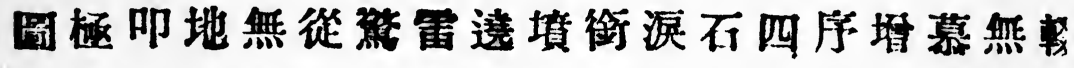

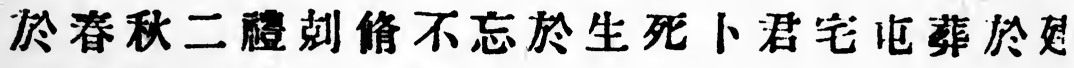
春門外造丘安之禮也 


\section{Appendix No. III}

The original text of the Nestorian Hymn discovered by Prof. Pelliot at Sha-chou in $\mathbf{1 9 0 8 .}$

景 教三威 蒙 度讃

无上諸天深敬戥。大地重念普安和。人元冝性蒙传

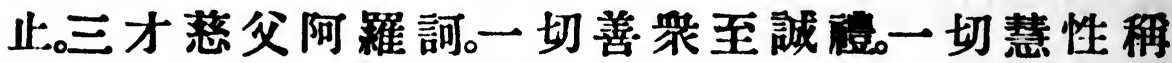
譛歌。一切含真盡歸们。蒙毠慈光救離魔。難尋無及

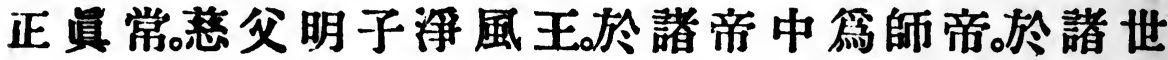

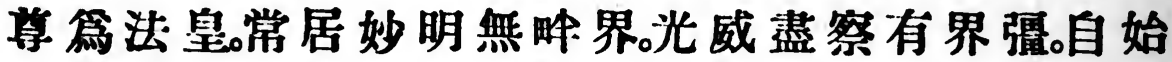

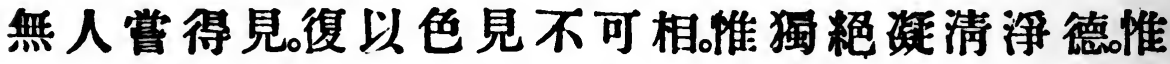

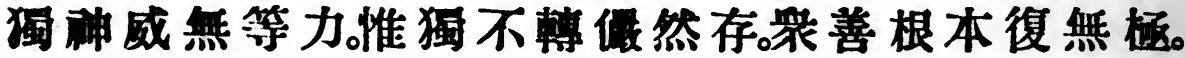

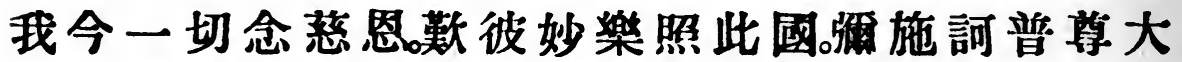
聖子。廣度苦界救無億常活命王䓗喜羔大普躲苦

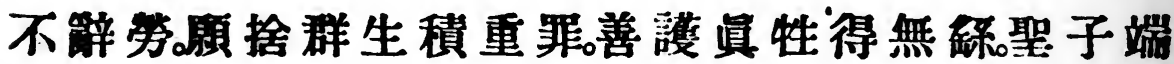
任父右座。其座復超無影高。大師願彼乞等請。降㭜 使免火江漂。大師是我等慈父。大師是我等聖主。大 師是我等法王。大師能篇普救度。大師慧力助諧窝。 諸目瞻仰不鳌移。復與枯燋降甘露。所有蒙潤善根

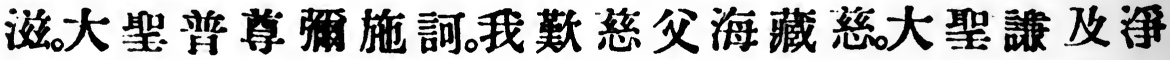
風性。請㠜法耳不思議。 
Appendix No. IV.

The Chinese texts for the quotations on pages 150 and 151.

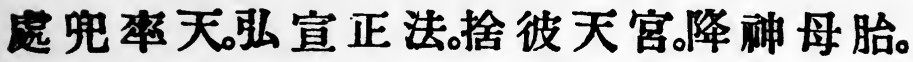

舆馨自稱。吾當於世篇無上尊。

䊝梵奉侍天人䯞仰。

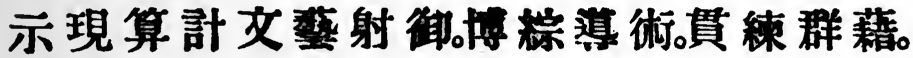

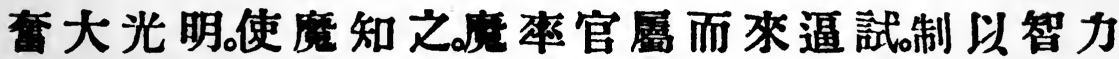

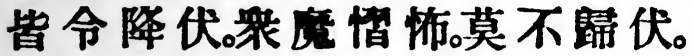

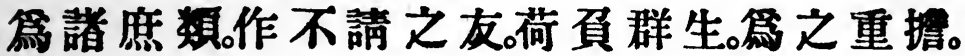

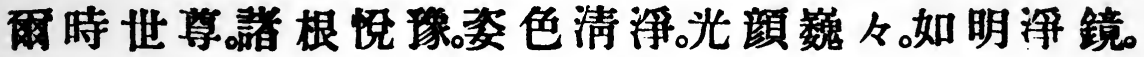

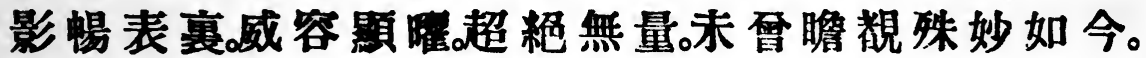

何不莱世事。勤行求道德。可獲極長生。㡲樂無有極。

有田喜田。有宅要宅。

有一復少一。有是少是思有唯等。

何不莱䊬事。各曼强健時。努力勤修善。精進願度世。

可得極長生。如何不求道。安所須待。欲何樂哉。

作善得善。篇道得道。

以善攻惡。

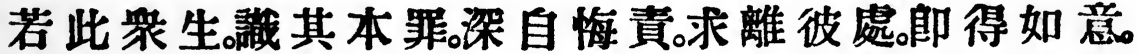

往詣無量壽佛所。是故應當明信。

隨意所筫。皆可得度。 
Appendix No. $\mathbf{\nabla}$.

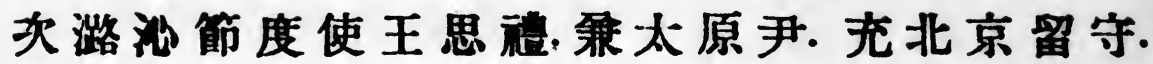

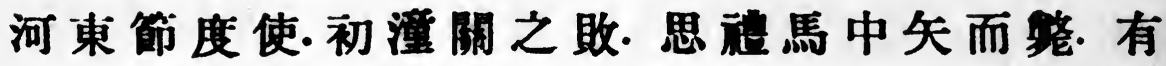
騎卒衉厓偯光苌.下馬授之. 問其姓名. 不告而

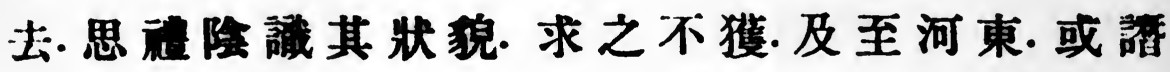
化州刺史河西辛雲京雲京荿州金城人㞗河西 路)思视怒之. 雲京惟. 不知所出. 光或時在雲京

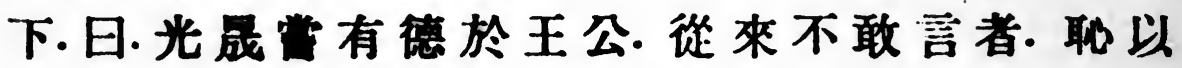
应此取卧耳. 今使君有急. 光最請往見王公. 必

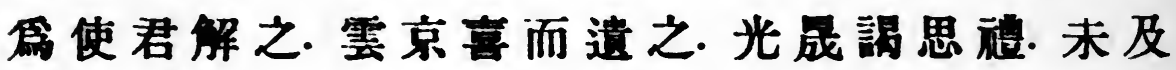

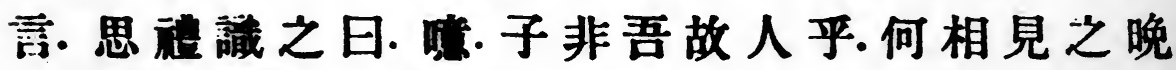

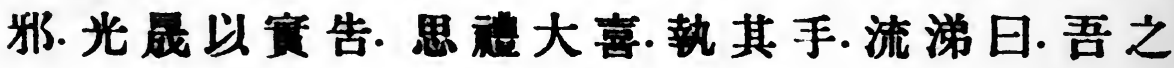
有今日皆子之力也. 吾求子久矣. 引與同擝坐.

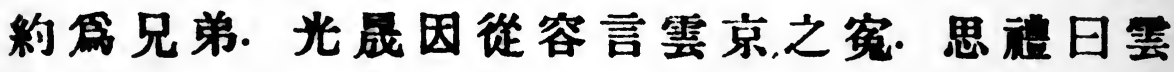
京過亦不細. 今日特感故人捨之. 即日推光苌.

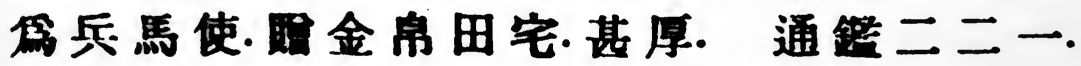

(B)

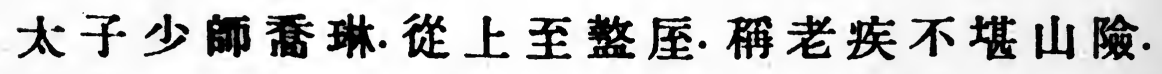

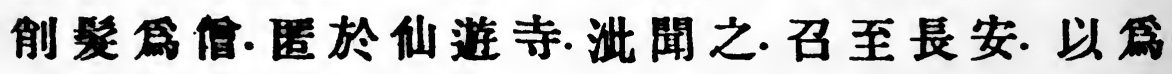

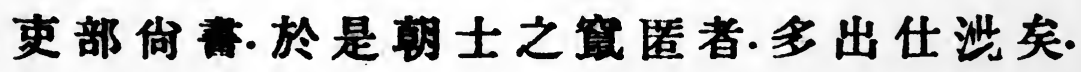


(C)

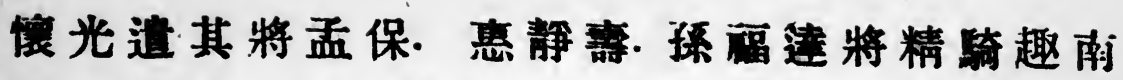

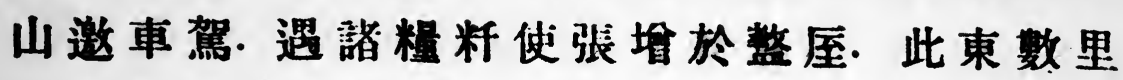
有佔桐. 吾眝䊓誌.
(D)
西郊萰若
羊士楞

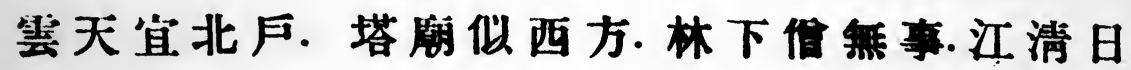
正長. 石泉盈掬冾. 山實滿枝香. 惄莫侮心印. 氣 言交已忘.
(E)

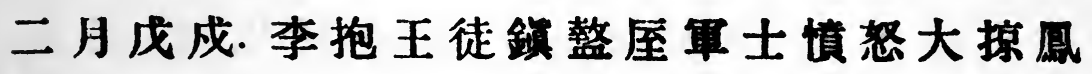
䦀坊市. 數月乃定. 
(F) Postal system of T'ang Era as described by Liu Tsung-yüan in 804 A. D. In this we read about Chou-chil. (Cf. p. 23.)

\section{館圛使壁䘥}

凡萬國之會. 四夷之來. 天下之道途畢出於邦 畿之內. 奉貢輸賦. 修職於王都者. 入于近關. 則 背重足鍇轂以疆有司之命. 徽令睗予布政於 下國者. 出于甸服而後按行成列. 以就諸侯之 館. 故館驛之制. 於千里之内尤重. 自萬年至于 渭南其驛六. 其蔽日華州. 其關日潼關. 自華而 北界于梠陽其驛六. 其蔽日同州. 其關日蒲津.

自灞而南至藍田. 其驛六. 其蔽日商州. 其關日 武關·自長安至于䀅屋. 其驛十有一. 其蔽日渄 州. 其關日華陽. 自武功而西. 至于好时. 其圛三, 其敬日鳳翔府. 其關日陗關. 自渭而北. 至于華 原. 其驛九.其蔽日坊州. 自战陽而西. 至于奉天. 其驛六. 其蔽日呵州. 由四海之内. 總而合之. 以 至于關. 由關之内. 率而目之. 以至于王都. 華人 荑人往復而授館者. 旁午而至. 傅吏泰符而䦥 其數. 䅫吏執腈而書其物告至告去之役. 不絕 於道. 寓望迎勞之禮. 無䧤於日.而春秋朝陵之 


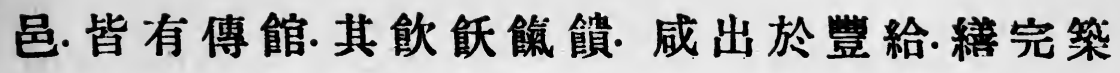
復. 必歸於整頓.列其田租. 布其貨利. 權其入而 用其積. 於是有出粑奇贏之數句會改校之政. 大曆十四年. 始命御史篇之使. 俾改其成以質 于.佾書. 季月之晦. 必合其簿書. 以視其等列. 而 校其信宿. 必稱其制. 有不當者. 反之於官. 户其 事者有勞焉. 則復于天子而優升之. 勞大者塤 其官.其次者降其調之數. 又其次诲異其放績. 官有不職則以告而罪之. 故月受俸二萬于太 府. 史五人. 承符者二人. 皆有食焉. 先是假廢官 之印而用之. 貞元十九年. 南晹韓泰告于上. 始 蹼使印而正其名. 然其嗣當斯職未賞有記之 者. 追而求之. 荅數歳而往則失之矣. 今余営之 記. 透以韓氏篇首且曰修其職故首之也. 
(G) The description of the Banqueting Hall at Chou-chih by Liu Tsung-yüan in 802 A.D. The whole text is translated on page 23 of the Introduction.

\section{䀅屋縣新食堂記}

真元十八年五月某日. 新作食堂于影內之右. 始会食也.自兵益以來. 西郊捍戎. 夥篇軍量二 十有六年.群吏咸寓于外.兵去邑荒. 棟宇傾圮. 又十有九年. 不克以居. 由是粕之聯事離散而 不屋.凡其官僚罕或覞見. 及是主簿某病之.於 是且掌功役之任. 瑓庫既成繁校既修. 取其稌 財以粠斯堂. 其上棟自南而北者二十有二尺.

周阿峻噘.列㮎凨其飾之文質. 階之高下. 視 邑之大小與群吏之秩. 不盛不盈. 离山在前. 流 水在:下.可以俯仰. 可以宴樂. 既成得羡財. 可以

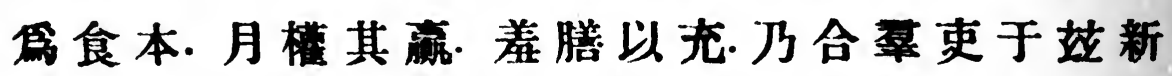
堂.升降座起. 以班先後.始正仿秩之叙. 䄈儀笑

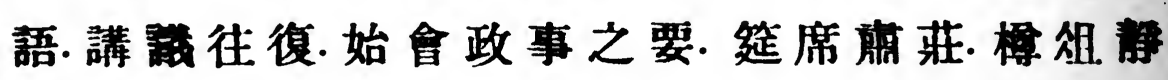
嘉. 燔炮烹倠. 益以酒酷. 始獲僚友之樂. 卒事而 退. 舉欣欣焉. 日惟融食之來古也. 今京師百官 咸有斯制. 甸服亦王之內邑. 且官有聯圆. 則宜 統會以齊之也. 敖之離而今之合. 其得失也遠 
甚. 我是以婣焉而菲. 行焉而和. 翠疑以止. 嘉言 以彰. 旨乎其在此堂也. 不惟其馨香醉飽之謂 某之力也夫. 宜伐石以志使是道也.不替于後. 乃列其事來告使余書之。 
(H) The Poem about Chou-chih by Lu. The translation of the poem in given on page 25 of the Introduction.

早春歸䀅厔寄耿浯李端盧 綸

野日初晴麥陮分

幾家廢并生新草

引水忽警水滿澗

可憐荒蔵青山下
竹園村巷鹿成群

一樹繁花對古境

向田空見石和雲

惟有松枝可奇君 
Appendix No. VI.

The Edict entitled " the Proclamation ordering the destruction of the Buddhist monasteries" by the Emperor Wu-Tsung, 845 A. D. The whole translation of the text is given on pages 86-89 of the Introduction.

\section{毀 佛 寺制}

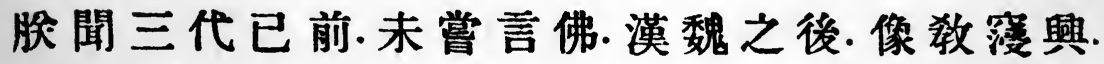
是由季時.傳此異俗.因緣染㚙. 蔓行滋多. 以当 蛪耗國風而漸不學. 誘惑人意而䍃益迷. 泊於 九州山原.兩京城䦥·僧徒日廣·佛寺日崇·䇨人 力於土木之功. 萦人利於金寶之飾·遺君親於 師資之際. 違配偶於戒律之間. 壇法害人. 無通 此道. 且一夫不田. 有受其耭者. 一婦不变. 有受 其寒者.今天下僧尼. 不可勝數. 皆待農而食. 往

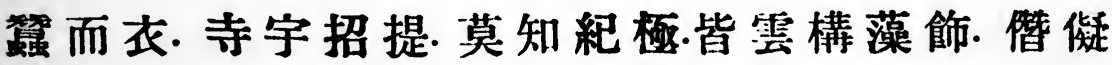
宮居. 晋宋齊梁. 物力调㡜. 風俗澆詐. 莫不由是 洏致. 况我高祖太宗. 以武定禍锁. 以文理華夏. 執此二柄. 是以經邦. 豈可以區區西方之敉. 與 我抗衡哉. 貞觀開元. 亦嘗鳌革·划除不盡. 流行 轉㬎.除博覧前言. 旁求奥議. 警之可革.斷在不 疑. 而中外諸臣.協予至意. 條疏至當. 宜在必行. 
隹千古之虂源. 成百王之典法. 濟人利衆. 予何

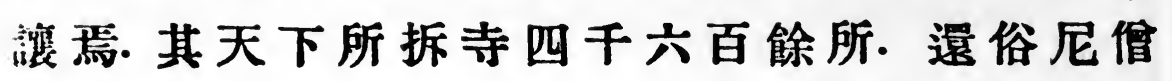
二十六萬五百人. 收充兩稅户。拆招提籣若四 萬馀所. 收亮膄上田數千萬頃. 收奴婢震雨秷 戶十五萬人. 隷僧尼屬主客. 顯明外國之敎. 勒 大秦穆護裉三千餘人還俗. 不雜中華之風. 於 戲. 前古未行. 似將有待. 及今盡去. 豈謂無時.

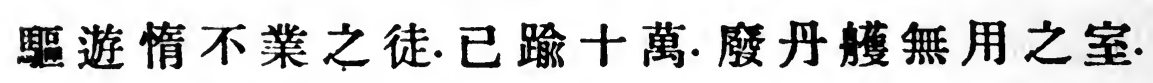
何富億千. 自此清淨訓人. 慕無篇之理. 簡易齊 政. 成一俗之功. 將使六合駖黎. 同歸皇化. 份以 革弊之始. 日用不知. 下制明廷. 宜體予意. (見古文淵擥正集二十九卷第四十八面) 
Appendix No. VII.

$\begin{array}{ll}\text { (A) } & \text { in the Chinese History. }\end{array}$

武帝即位. 廢浮圖法. 天下毁寺四千六百. 招提

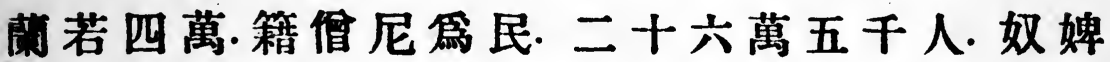
十五萬人. 田數千萬頃. 大秦穆護获二千餘人.

上都東都毎街留寺二。毎寺僧三十人. 諸道留 佮以三等.不過二十人.膄田繁錢䢪戶部. 中下 旧給寺家. 奴婢丁壯者爲兩稅戶人.十故以僧 尼. 既盡兩京. 悲田餈病坊. 給寺田十頃. 諸州七

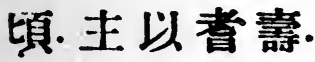

(見食貨志第四十二唐書五十二第入頁) (B)

會昌五年秋七月.上惡僧尼耗虽天下. 欲去之 道士趙歸噵等復酄之. 乃先毁山野招提蘭若. 至是栜上都東都兩街各留二寺. 毎寺留僧三 十人. 天下節度觀察使治所. 及同華商汝州各 留一寺: 分爲三.等. 上. 等留僧二十人. 中等留十 人.下等五人. 餘僧及尼. 亚大秦穆護稵僧. 皆勒 歸俗. 寺非應留者. 立期命所在毁撒. 仍遣御史 分道督之. 財貨田産亚浔官. 寺材以荤合廨驛 


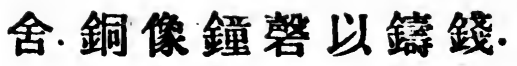

(見資治通鑑第二百四十八绻唐紀六十四第

九頁) 
Appendix No. VIII.

The letter addressed to the Emperor Wu-Tsung by

His Prime Minister Li Yü in 845 A. D.

(See page 89, the Introduction.)

李文饒文集卷二十。會昌一品制集

\section{賀廢毁諸寺德音表}

臣某等伏奉今日制拆寺蘭若共四萬六千六百 餘所. 逧俗僧尼. 抹奴婢需兩稅戶. 共約四十一 萬餘人.得良田約數千頃其僧尼令綠主客戶.

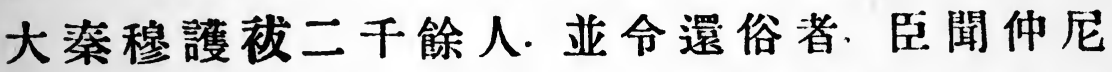
祖迅圭舜. 害章文武. 大弘聖道. 以黜異端. 末季 以來. 斯道久閔. 不遇大䏝. 孰能極之. 臣某等中 謝伏以三王之前. 皆垂拱而理. 不可得而言也. 厥後周美成康. 漢稳文景. 至化深厚. 大道和小 人自禀於孝慈. 俗必瑧於化壽堂當有外夷之 教. 點中夜之風. 東漢楚王英. 始盛桑門之饌. 淪 於左道桓帝更增㞗盖之飾. 蹄於销政. 魏之三 祖. 西晉太康踓君非大㧝. 伲非上哲. 然唒祖向 老莊. 斯敎末行. 至東唯因哭人之佻薄. 襲係權

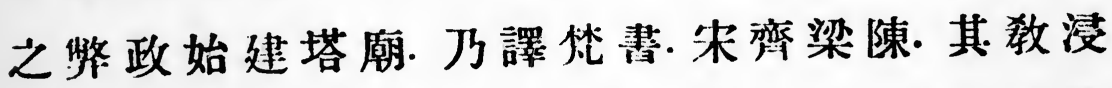
盛. 好大不經之說. 徆乃詩書. 因報找濟之談. 隆 
於仁孝. 連祚浮促. 篡奪相尋. 二百年間. 五覚朝 市君無殷宗之福臣摩衛武之年感驗寂䇣斯可 明矣·高宗祖堯皇需. 方欲划除斯整. 掃刷中區.

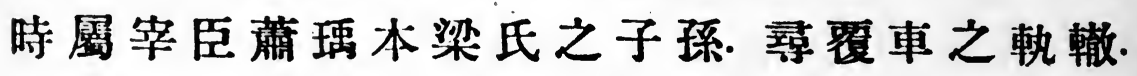
廢格明詔. 以迄于今. 遂使土木興妖. 山林增構 一㒈之秀必極雕鎸一川之膄已布高刹鬼功不 可. 人力鼻堪耗䝴生靈侵減征稅國家大虽. 千 有餘年. 伏惟仁聖文武章天成功神德明道大 孝皇帝陛下. 明紹於天. 粹合於道. 黜覇圖而功 盛. 入聖域而德優. 常欲天下之動. 咸貞於一. 以 一䨐之蔽. 思必無邪. 先定良心. 獨廢英斷. 破逃

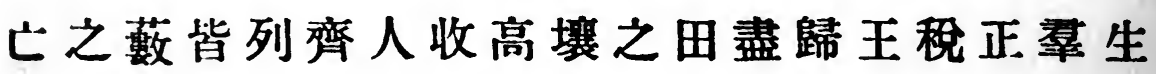
之大惑返六合之澆風. 出前聖之謨. 雼後王之 法. 巍槐功德. 煥炳圖書. 臣筙位樞衡. 莫能裨益. 愧無將明之効. 徒懷鼓舞之心千古未逢. 百生 何幸.不任林賀踴躍之至. 
Appendix No. IX.

The Persecution against Buddhists in $845 \mathrm{~A}$. D. as described by a contemporary historian.

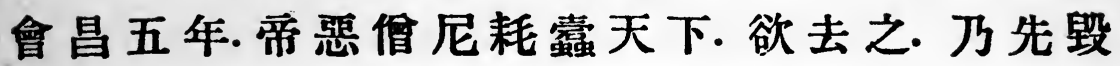
山野招提蘭若. 復勅上都東都各留二寺. 每寺 留僧三十人. 天下節鎮. 各留一寺. 寺分三等. 留 倌有差. 餘僧及尼. 亚勒蹛俗. 寺皆立期毀·撤. 仍 遣御史分道督之. 田貨田產亚沟官. 寺材以茸 公㡿驛舍. 銅像鐘馨以鑄錢. 凡天下所毀洔四 千六百餘區. 招提蘭若四萬餘區. 歸俗僧尼二 十六萬五百人. 收良田數千萬頃. 奴婢十五萬 人.五臺僧多亡奔. 幽州李德裕召進奏官謂曰. 汝速白本使.五臺僧爲將. 必不如幽州將. 爲卒. 必不如幽州卒. 何第虚取容納之名. 染於人口. 獨不見刲從諫招聚無算閑人. 竟有何谷. 張仲 武乃封二刀付居庸關日. 有遊僧入境則斬之. 頁八十四然九十二集正签淵文古見 
Appendix No. $\mathbf{X}$.

The Imperial Rescript mentioned in the Nestorian Iuscription as preserved in the Book called T'ang-hui-yao compiled in the 11 th century.

貞觀十二年七月·詔日.道無常名. 聖無常體·隨 方設敎密濟翠生. 波斯僧阿羅本. 遠將經教来 㱆上京.詳其敎旨·立妙無雼·生成立要. 濟物利 人. 符行天下所司. 即於義寧坊建寺一所. 度僧 柱一人.

(見唐會要四十九卷十頁)

Appendix No. XI.

The Imperial Edict of the Emperor Hsüan-Tsung in 745 A. D. (See page 130, the Introduction.)

火珼四載九月.詔日.波斯經敎.出自大秦. 傅㕷 洏來. 久行中國.爱初建寺. 因以雼名. 將欲示人. 必修其本. 其兩京波斯寺. 宜改篇大秦寺.天下 諸府郡置者亦淮此.

(兒唐會要四十九然十頁)

Appendix No. XII.

Quotations from Hsi-an Topography showing the position of the Nestorian monastery.

(A)

義坊街東之北.波斯胡寺.

(見經訓堂諁書長安志十第五頁) 
(B)

義算坊十字街之東北. 波斯胡寺. 次南日居德 坊.

(見奥雅堂荍書兩京新記第十五卷六頁)

(C)

醴泉坊街南之東. 舊波斯胡寺.

(見經訓堂踥書長安志十第四頁)

Appendix No. XIII.

Quotation from " the New Catalogue of the Books (of terching) of S'akya in the Period of Chêng-yüan" (A. D. 785-804). (See page 71, the Introduction.)

乃與大秦寺波斯僧景淨依胡本六波羅密經摆 成七卷. 時瓷般若不閑胡語. 復未解唐言. 景淨 不諳梵交.復未明釋敎. 雖稱傳譯. 未獲牛珠. 圖 籍虚名.匪篇福利. 錄表聞奏·意望流行. 聖上浐 哲文明. 允恭釋典.察其所譯. 理弙詞疎. 旦夫釋 氏伽藍大秦僧寺. 居止既別. 行法全乘. 景淨應 傳彌尸訶敎. 沙門釋子弘阙佛經. 欲使教法區 分人無濫涉.正邪異類.涇渭殊流. (見貞元新定 釋敉目錄) 
The visit of P'an-na-mi, the Persian Chief and Bishop Chi-lieh in $732 \mathrm{~A}$. $\mathrm{D}$.

(See pages 76 and 225, supra.)

(A)

開元二十年九月. 波斯王遺首領潘那密與大 德僧及烈朝貢.

(見册府元氲九百七十一卷九頁)

(B)

開元二十年入月庚戌. 波斯王遣首領潘那密 與大德伯及烈來朝. 授首領扁果教. 賜僧紫袈 饻一副.及帛五十正放還蕃.

(見册府元鵃九百七十五卷第十三面) 
Appendix No. XV.

Opinions of Chinese experts on the Nestorian Stone.

(A)

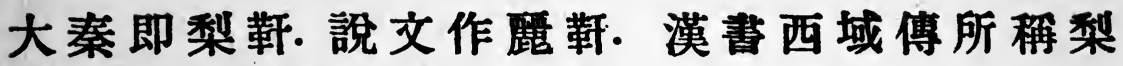
靽佟支. 臨西海者是也. 後漢書云. 以在海西. 故 亦云海西國. 水經注恒水. 又逕波麗國. 是佛外 祖國也. 法顯曰. 恒水東到多摩黎靽國. 即是海 口. 䆁氏西域記日. 大秦一名鯬䩗. 道元據此. 藍 以黎靯雼即波麗矣. 敃條支即波斯國. 魏書云 地在忸密之西. 東去黎靬猫一萬里. 長安志義 蜜坊有波斯寺. 唐貞観十二年. 太宗霞大秦國 胡僧阿羅斯立. 應是大秦你人入中國之始. 合 之碑. 則云于義覃坊造大秦寺. 兩國所奉之教 畧同. 故寺名通用耶. 阿羅斯. 碑作阿羅本. 富是 敏求之誤.

(見關中金石記)

(B)

右景教流行中國碑.景教者西域大秦國人所立 教也. 舒元舆重臀寺碑. 襍夷而來者有摩尼瑪.

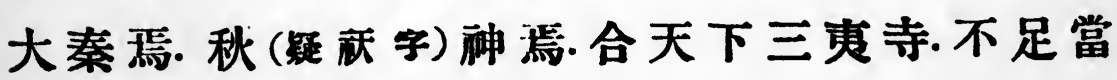


吾釋氏一小邑之數. 今麾尼祅神的久嘚. 不知 所自. 獨此碑叙景教傳授煩咩. 蓋始千唐衴! 大

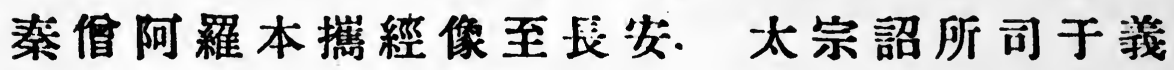
窑坊造寺一所. 度僧二十一人. 高等時崇阿羅 本爲鎮國大法主. 仍令㵔州各置景寺. 其偕皆

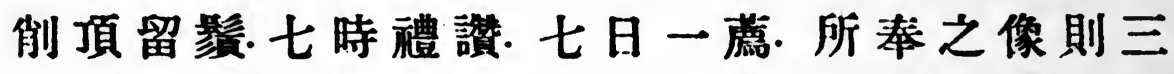
一妙身.无元眞主. 阿羅訶也. 今歐羅巴溙天主 耶蘇. 溯其生年. 當隋開皇之世. 或云即大秦遗 教. 未審然否. 後題太蔟月七日大耀森文日建 立. 所云大耀森文. 亦彼教中語. 火䋩布. 即火浣 布也。

(見潛研堂金石文践尾) 
Appendix No. XVI.

Mr. Ch'ien, a Chinese authority of "Metal and Stone writings," on the Nestorian Inscription.

萬曆間長安民鋤地. 得唐建中二年景敎碑. 寸:

大夫習西學者相秢謂有唐之世: 其郄已流行 中國. 問何以䍃景敎而不知也. 按朱敏求長笑 志㼁篎坊街東之北. 波斯胡寺貞觀十二年.太 宗鳳大秦國胡僧阿瞿斯立. 又云醴泉坊之柬 舊波斯寺.儀鳳二年波斯三卑路斯請建波斯洔. 神龍中宗楚客占第宅. 移寺于布政坊西南隅. 祅桐之西册府元龜. 天䞇四載九月. 詔日. 波斯 經敎出自大秦. 傳習而來. 久行中國.爱初建寺. 因以雳各. 将以示人. 必循其本. 其兩京波斯寺. 宜改䨌大秦寺. 天下諸州郡宜准此. 此大秦䔱 建立之緣起也. 碑云. 大柇國有上德曰阿䍜本. 貞觀九祀至于長安.十三位秋七月. 于京師䄉 㿾坊建大秦寺. 阿羅本即阿羅斯也. 寺初名波 斯. 義鳳中份仍舊名. 天贊四載. 方改名大秦. 碑 言貞觀中詔賜名大秦持. 决僧之誇詞也. 舒元 舆重臀寺碑云. 合天下三夷寺. 不足賞吾釋氏 一小邑之数. 釋寺唯一. 夷寺有三. 摩尼即末尼 
也. 大秦即景敎也. 祅神即波斯也. 今据元興記 而詳考之. 長安志日. 布政司西南隅胡祅詞武 德四年立西域胡天神也. 同有薩寶府官主问 纭神. 亦以胡㒭稱其職. 東京記引四夷朝貢圆 云. 康國有神名祅. 畢國有火祅詞. 疑因是建廟. 王溥唐會要云. 波斯國西與吐蕃康居接. 西北 拒佛菻(㽢大秦也)其俗事天地日月火水諸神. 西域諸胡事火祅者. 皆詣波斯受法. 故日波斯 教即火祅也. 宋人姚䈭日. 火祅字從天. 胡神也. 挳所謂摩䤃首羅. 本起大波斯國. 號蘇魯支. 有 弟子名立畺. 居波斯國大總長如火山. 後化行 于中國. 然祅神專主事火. 而宽以篇摩酷首羅 者. 以波斯之教事天地水火之總. 故諸胡皆锠 受教. 不專一法也. 大秦之敉. 本不出于波斯. 及 阿羅訶者出. 則自別于諸胡. 碑言三百六十五 種之中. 或空有以淪二. 或禧祀以邀福. 彼不欲 過而問焉. 初假波斯之名以入長安. 後乃改名 以立異. 地志稳默德那爲回回祖國. 其教以事 天雼本. 經有三十藏. 凡三千六百餘尞. 西洋諸 
國皆宗之. 今碑云三百六十五種. 局隨結䡴. 豈 非回回祖國之三十藏與. 若未尼則志磐統紀 序之獨詳. 開元二十年敕云.末尼本是邪見. 安 稱佛法. 既篇西胡師法. 其徒自行. 不須科䛶. 大 歷六年. 回紀請荆掦等州. 置摩尼寺. 其徒白衣 白冠. 會昌三年秋. 敕京城女末尼. 凡七十二人 皆死. 梁貞明六年. 陳州末尼反.立母乙雼天子. 發兵禽斬之. 其徒不茹葷酒. 夜聚媱穢. 畫魔王 踞坐. 佛雼洗足云. 佛上大乘. 我乃上上乘. 蓋末 尼雼白雲白蓮之流. 于三種中爲最劣矣. 以元 奥三夷寺之例. 覆而斷之. 三夷寺皆外道也. 皆 邪敎也. 所謂景敎流行者. 則夷僧之黠者. 稍通 文字. 煷脣拭舌. 安爲之詞. 而非果有異於摩尼 祅种也。

(見錢氏景敎考) 
A criticism of Mr. Ch'ien's view about the Nestorian Inscription.

右錢氏景敎考.日大泰, 日回回.日末尼. 大秦則 范蔚宗己雼立傳. 末尼因回回以入中國. 獨回 回之敎. 種族墓行. 士大夫且有慕而從之者. 其在唐時史固稃其創邸第佛洞. 或伏甲其間.

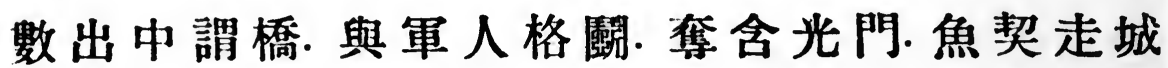
外.而麻尼至京師. 葴往來西市商珼. 頗興霆索

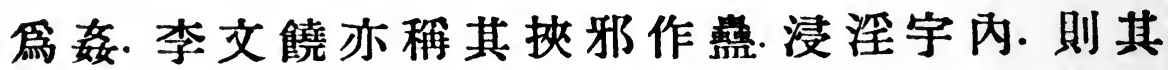
可絶者.匪特非我族類而已. 作景敎續考. 回回

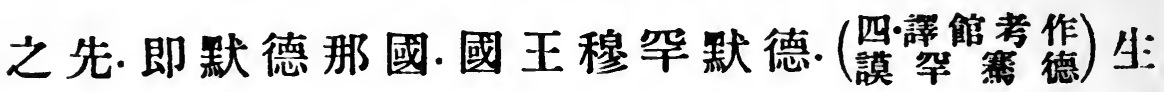
而靈異.臣服西域. 諸國拿篇別諳援爾. 華言天 使也. 而天方古史稃阿丹. 泰真宰明諭. 定分定 制. 傅及後世.千餘載後. 洪水泛濫. 有大聖努海 受命治世. 使其徒衆四方治水. 因有人焉. 此去 阿丹降世之初. 蓝二千稌葴. 後世之習清县之 教者.乃更衍其說.日阿丹傳施師. 師傳努海. 海 傳易卜刺欣. 欣傳易训馬儀儀傳母撒. 撒傳逹 五德. 德傳爾撒. 爾撒不得其傳. 六百年. 而後穆 品默德生. 命曰哈聽. 楩言封印云. 按唐之回籺. 
即今之四回. 回䋁之先雼匈奴. 元魏時號高車. 或日栜勒. 日鐵勒. 其見於魏收李延壽宗祁之 史. 班班可改. 異端之徒創爲荒忽幽怪之談. 以 欺世而矓俗. 如天方古史云云者. 其尤可軒渠 者也. 又言國中有佛經三十藏. 自阿丹至爾撒. 凡得百十四部. 如討刺特. (降興名撤) 則逋爾.

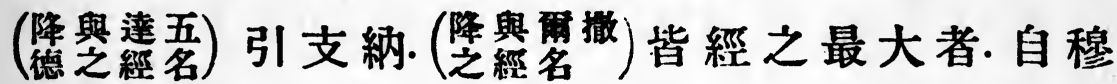
罕默德. 按經六千六百六十六章. 名日甫爾加尼. 此外雼今清䢐所誦㕷者. 又有古爾阿尼之寶 命真經. 特福西爾噶最之噶最眞經. 特酔西爾 咱吸堤之咱希德真經. 特稫西爾白索義爾之 大觀檤經. 密䧟索德之道行推原經. 勒瓦一合 之昭微經. 特卜総爾之大觀經.侏璃昧任.不可籍 詰. 而其埭在四驛館者. 回回特爲八館之首. 問 之則云書承策楷草. 西洋若土魯番天方撒爾 兒罕占城日本直臘瓜哇滿刺加諸國. 皆用之. 夫䇡楷草. 篇吾中國書法之次第. 其徒特借以 种其誕幻. 而顧倒道而行. 迕道而說. 以篇得天 之明諭. 噫. 是何其無忌憚之甚也. 今以其教之 
在中國者而考之. 隋開皇中國人撒哈八撒阿 的斡思葛. 始以其教來. 故明初用回回歷. 其法 亦起自開皇. 至唐元和初. 回絰再朝獻. 始以摩 尼至. 其法日晏食. 领水. 茹龩. 屏湩酪. (見新唐意) 二年正月庚子請於河南府.太原府. 置摩尼寺.

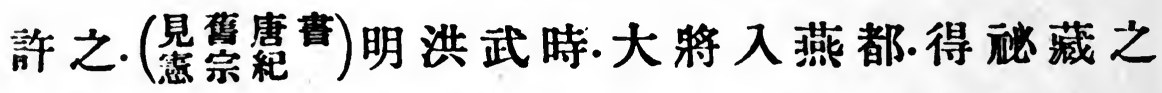
書數十百册. 稱乾方先聖之書. 中國無解其文 者. 太祖䡃翰林糄修馬沙亦黑馬哈麻譯之. 而 回回之教. 逐盤互於中土.而不可復遺矣. 至於 天方. 則古筑冲地. 鹤名天堂. 又名西域. 其國本 與回回篇鄰. 明宣德間. 万始入貢. 而今之清善 福拜寺逐合而一之. 念軆意課朝五之類. 月無 虚夕. 異言奇服. 招播過市. 而恬然不以篇怪. 其 亦可謂不道之民也已.

(見道古堂文集) 
Appendix No. XVIII.

On the Nestorian Stone by Mr. Wang, a Chinese

expert on "Metal and Stone writings."

按此碑原委. 景敎考言之已詳. 潛研跋謂今歐 䍜巴. 奉天主耶稣. 或云即大秦遺敎. 据碑有制 十字以定四方之語. 今天主教常擧手作十字. 與碑言似合.然 日下舊聞考. 載天主堂. 構於 西洋利瑪竇. 自歐邏巴航海九萬里入中國. 崇 奉天主云云. 歐攞在極西北. 須從海中大西洋 迤西而南. 經小西洋.大南洋. 抵占城湓島. 泊交 廣. 以達中土. 有九萬里之遠也. 若大秦國. 以本 朝職方會覽. 四繁圖說諸書考之. 大秦一名如 德亞. 今稱西多爾. 在歐邏巴南. 雖陸路可通. 而 谌遼裳. 似不能合篇一也. 杭氏續考. 專論回回 之敎. 其說亦詳. 然謂唐之回紀. 即今之回司. 說 亦末然. 唐之回䋁. 即问鵑. 其地與薛延陀爲隣. 距長安祇七千里. 若包包有租國. 以今職方諾 書考之. 在古大秦國之東. 一名伯爾西亞. 今稱 包社大白頭番. 與回紇隔遠. 亦不能合霨一也. 碑稳大秦國上德阿羅本. 兩唐書西域傳所載 
諸國. 惟拂菻一名大秦. 然無一語及景敎入中 國之事. 唐會要稱波斯 國. 西北距佛菻.(即拂森)則 波斯在拂菻之東南. 故長安志所載. 大秦寺其 初謂之波斯寺. 天䫦四載詔書波斯經郄. 出自 大秦. 則所謂景教者實自波斯. 而溯其源於大 秦也. 唐西域傳波斯距京師萬五千里. 其法润 祅神. 興唐會要語同. 然亦無所謂景敉者. 祅神 字當从示从天.讀呼煙功. 與从天者別. 說文云. 關中謂天霨祅. 廣韻云胡神. 所謂關中者. 統西 域而言．西北諸國事天最敬。故君長謂之天可 汗. 山謂之天山. 而神謂之祅神. 延及歐䍜巴. 奉 呚謂之天主. 皆以天該之. 唐傳載波斯國俗. 似 與今包包相同. 此碑稱常然莲寂. 战陡畺威. 亭

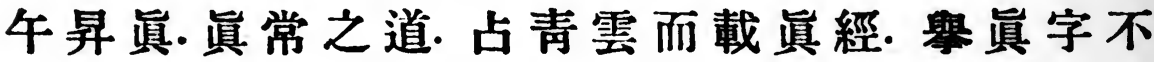
一而足. 今所建包包堂. 謂之體拜寺. 又謂之眞 教寺. 似乎今回回之敎. 未始不源於景教. 然其 中自有同異. 特以彼敎難通. 未能剖析. 姑備錄 諸說. 以資博改. 至碑稱景教. 景字之義. 交中只 二語云. 景㜚告群. 慗景日以破暗府. 是與景星 
景光臨照之義相符. 然則唐避諱而以景代两. 亦此義興. 
Appendix No. XIX.

Dr. Léon Li's writing on the discovery of

the Nestorian Stone, written in 1625 A. D.

\section{讀景数碑書後}

虎居靈竺閂. 岐陽同志張噔處. 惠寄唐碑一幅 日.通者長安中掘地所得. 名日. 景敎流行中國 碑澒. 此敎未之前聞. 其即利氏西泰所傳聖教 乎. 余讀之良然. 所云先先無元. 後後妙有. 開天 地. 匠萬物. 立初人. 衆聖元尊真主. 非皇皇天主. 塁能賞此. 其云三一妙身. 即三位一體也. 其云 三一分身. 即费略降誕也. 其云同人出代. 云室 女誕聖於大秦. 即以天主性接人性. 胎於如德 亞國室女瑪利亞而生也. 景宿告样. 異星見也. 酰耀來貢. 三君朝也. 神天宣慶. 天神降也. 亭午 升䛧. 則救世傳敎功行完. 而日中上昇也. 至於 法浴之水.十字之持. 七時禮讚. 七日一萀. 悉與 利氏西來傳述. 規程炤合. 而今云陡斯. 碑云阿 羅訶. 今云大傲魔魁. 碑云奖殫. 則皆如德亞國 占經語. 不曰如德亞. 而曰大秦. 考唐書拂菻國. 一名大秦. 西去中國四萬里. 又考西洋圖誌. 如 德亞畿東一道. 其名日秦. 道里約略相同. 阿羅 
本䧳. 殆從此邦來者. 故以大秦稱云. 其至長安 也. 以貞觀九年. 上遡耶稣降生近六百禩. 是時 宗徒傳敎. 殆徧西土. 大唐德威遠暨. 應有經像. 重譯而來. 爾乃宰相郊迎. 翻經內殿. 䉆造大秦 寺於義寧坊. 命名景呚. 景者大也. 炤也. 光明也. 大帝時又栜諸州各置景寺. 崇奉之至. 顯與儒 釋立三敎. 共峙罣宇. 非特柔懷異域。昭王會一 統之盛而已也. 聖曆則武氏宣淫. 先天則太平 镜政. 貞克既相挺迕. 水火應必煎意. 用壯相傾. 理同盜㥧. 喎來無鄉. 蓋千古有同慨焉. 羅含及 烈. 重振斯文.佶和再來. 渙頒袞剳. 立肅代德四 朝. 寵資䍾渥. 沼陽重廣法堂. 依仁施利. 修擧哀 䄰七端. 遂勒此碑. 以紀葴月. 其頌中多迅唐德. 亦具景敎大指. 所稃賜良和. 愁景日. 明著肇我 人類. 以及補贘救世之恩. 而貞觀所譯. 並所留 二十七部經交. 即今具葉藏中. 或少有可检者. 所疑傳教士. 曷以僧名. 則緣彼國無分道俗. 男 子皆髧. 華人强指爲僧. 渠輩無能自異云爾. 即 利氏之初入五. 羊也. 亦復數乎混跡. 後遇唯太 


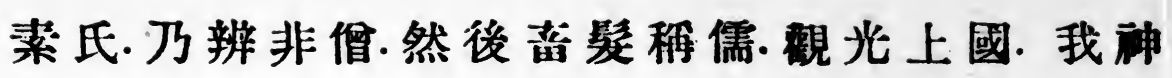
祖禮隆柔遠. 睗館多年. 於時文武大臣. 有能繼 房郭之芳踪. 演正䢐之絕緒者乎. 七千部奥義 宏鿷. 梯航嗣集。開局演譯. 良足以增輝册府. 軼 占昭來. 其如道不虚行. 故迄今份有所待. 三十 稌載以來. 我中土釉士. 習見㕷聞. 於西賢之道 行. 誰不歏異而敬禮之. 然而疑信相參. 詑爲新 說者. 办繁有焉. 詎知九百九十年前. 此教流行 已久. 雖世代叞興不一. 乃上主之景命無渝. 是 佑諸婜. 間關無阻. 更留貞石. 忽効其㶾. 所缽侣 覆閣下: 不忍令魔銅重封天路絡䦥. 故多年秘

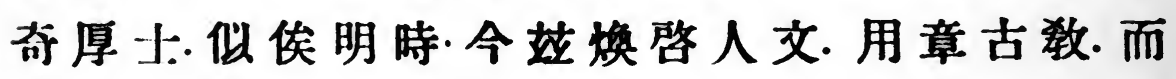
後乃知克己昭事. 俾無忝生而怛死. 此學自昔 有聞. 唐天子份知菲事. 而况我聖朝重熙累洽.

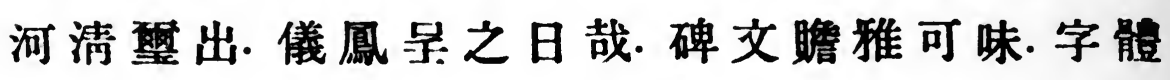
亦避媚不俗. 世之不乏欣賞者. 要於返而證之 六經. 諸所言帝言天. 是何學術. 資諸往聖. 量所 問官問軆. 何隔華夷. 即如䚈九萬里外. 繼踵 遠夹. 何以捐軀䘖道. 九死不悔者. 古今一轍. 而 
我輩不出戶庭. 坐聞正真學脈. 得了生死大事. 不可謂全無福䊏者. 何以份生疑阻. 悖吾孔孟 知天事天之訓. 而不整且驚乎. 且借碑作兂. 明

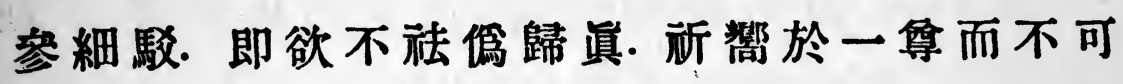
得. 不然者. 無諭詭正殉魔.自嗞生理. 政恐蜉蝣 生死。相尋共作僇民. 趈豬房梁公. 郭汾陽王. 已 雼絕德而况其進焉者乎.

天啓五年. 瓷在旃蒙赤奮若. 日緾參初度. 凉㟟 居士.我存李之藻·盟手謹識.

(見陽瑪諾唐景教碑頌正詮) 


\section{Appendix No. XX.}

Dr. Paul Hsü's writing on the Nestorian Stone in 1627 A. D. The Quotation from his book called "The Iron Cross."

近天啓乙丑·長安掘地得碑. 題日. 大唐景敎流 行中國碑.碑首冠以十字. 亦一證也. 碑中言景 教自唐貞觀九年. 大德阿羅本始奉以入中國. 國主大臣·如太宗·高·立·萧·代.憲.宗·及房立齢. 郭子儀之屬.悉皆煘奉. 貞觀十二年. 建寺於京

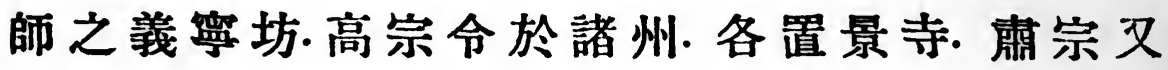
於靈武等五郡建立. 則絡唐之世. 聖化大行. 上 德高賢.比局林立·法壇道石. 周徧富宇. 何况汇 右世載文明. 虎陵素稱赤望. 有茹事迹. 豈足疑 乎.

天啓丁㓞六月朔書

(見徐光啓之鐵十字著) 
Appendix No. XXI.

Quotation from Emmanuel Diaz's work on the

Nestorian Inscription.

旅人偕同志唓 中朝也. 幾周甲子于落充.

一切賢者樂與遊.所著諸篇. 詳哉其迅之也. 乃

間者逞逞以諾䧳弗遠九萬梯航備歴. 至即如 歸. 不能無惑因賞具迅天主宏慈. 惠枝士民. 默辟至是. 導正闢邪. 宜頌宜感. 客謂默牌遠來. 訓正吾士若民.洵足頌感. 然曷弗于“數代以前. 俾吾先人咸管接引. 延迨今站. 誠所未解. 諾雀 時雳太息日. 淺战智慧. 乃安議天主意如是承. 雖然. 疑而思問. 請容進其說. 西聖奥斯定云. 富 者淲賓. 凡幾何逮速. 提衡在彼. 賓者不得預之.

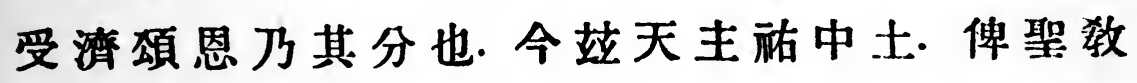
遠來弗頌受. 乃怨而責其後至也. 借如标䱦升

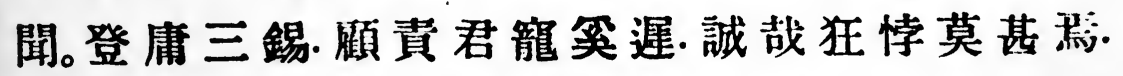
且中賢既言之矣. 就先傳. 就啳倦. 賢師郄其弟 子. 與天主率厥下民. 亦若是琵爾. 天未教人. 先

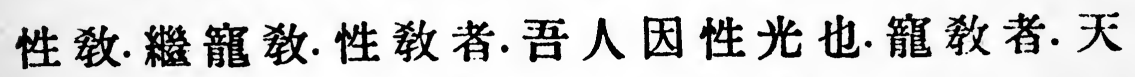
主超性光也. 未能盡厥因性. 頓冀超性. 是末少 先望䞨也. 前此中士. 若性郄弗遑. 份超性云平 


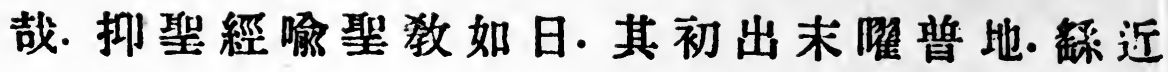

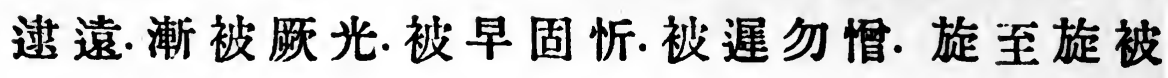
矣. 西方距中土幾九萬. 聖敎來滋逮固也. 理論

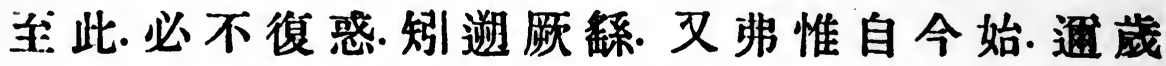
幸獲古碑. 額題景敉. 粤天主開闢迄降臨. 悉著 厥端. 時唐太宗九作. 霹天主降生後六百三十 五. 作. 至西鎬廣行十道. 聖敎之来. 茼千有餘荿 㕕. 是碑也. 大明天啓三年. 關中官命啓土. 于敗 墙基下獲之. 奇文古管. 度越近代. 置倣外金城 寺中. 岐陽誩公飡虞掦得一紙. 澬竟踴躍. 即遗 |i门志我存李公之藻. 云長安掘地所得. 名景教 流行中國碑頌. 殆與西學弗異乎。李公披勘. 良 然. 色喜曰. 今而後中士弗得然聖敎来何暮矣. 古先英辟顯輔. 朝野共欽. 昭燭特甚. 份奚有今 之人也. 繼而立扈徐公光綮. 愛其載道之文. 妌 装其紀文字鲁. 復鎸金石. 楷摹千古. 夫鴻碑較 著. 期鑒有三. 似勿更䁈. 惟碑旨淵義古. 不敏慮 筧者未辨. 或唒託其詞以固前惑也. 因弗避膚 拙詮劂概. 需來者孚券云. 大明崇阽辛已孟春 
之望陽瑪諾題.

(見唐景敎碑澒正詮) 
Quotations from the Chinese historical works concerning

Ta-ch'in and Fu-lin.

(A)

初漢使至安息安息王令將二萬騎迎於東界去 王都數干里行比至過數十城人民相屬甚漢 使逼而後發使隨漢使來觀漢展大以大鳥卵及 黎軒羓矓人献于漢.

(見史記第一百三十三卷大宛列傅第六十三) (B)

武帝始遣使至安息王令將將二萬騎迎於東界 東界去王都數千里行比至過數十城人民相屬 世真之欲反榴因使隨漢使者來觀漢地以大鳥卵 及黎軒矓人献於漢天子大說。師古古说

(見前漢書第九十六卷上西域傳第六十六上)

(C)

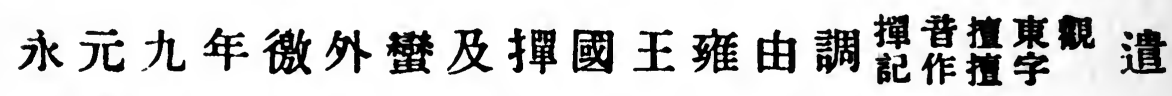
重譯奉國珍䆩和耑賜金印紫綬小君長皆加印

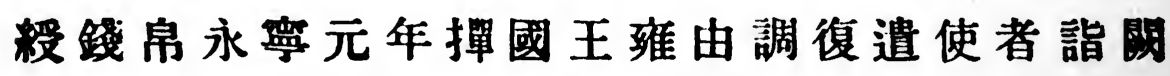
朝賀献薬及司人能㭠化吐火自支解易牛馬頭 又善跳丸數乃至千自言我海唒人海西即大秦 
也撣國西南通大秦明年元會安需作樂於庭封 雍由調篇漢大都尉賜印綬金銀綵緇各有差也.

(見後漢書第入十六卷南蠻西南夷列傳第七 十六)

(D)

條支國城在山上周回四十餘里臨西海海水曲 環其南及東北三面路絕唯西北隅通陸道土地

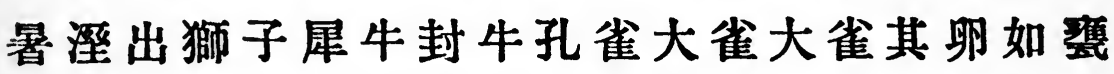
轉北而東復馬行六十餘日至安息後役屬條支 爲置大將監領諸小城焉安息國居和頭城去洛 陽二萬五千里北接與康居接南興鳥戈山離接 地方數千里小城數百戶口勝兵最爲殷盛其東 界木鹿城號霨小安息去洛陽二萬里章帝章和 元年遺使献獅子符拔符找形似麟而無角和需 永元九年都護班超遣甘英使大秦抵條支臨大 海欲度而安息西界船人謂英日海水廣大往來 者逢善風三月乃得度若遇迤風亦有二歳者故 入海人皆第三糧海中善使人思土戀慕數有 死亡者英聞之乃止十三年安息王滿屈復献獅 
子及條支大鳥時謂之安息雀自安息西行三千 四百里至阿蠻國從阿變西行三千六百里至斯 賓國自斯賓南行度河又西南至于羅國九百六 十里安息西海極矣自此南乘海乃通大秦其土. 多海西珍奇異物焉

(見後漢書第八十八卷西域傳第七十八)

大秦國一名黎鞬以在海西亦云海西國地方數 千里有四百餘城小國役属者數十以石第城郭

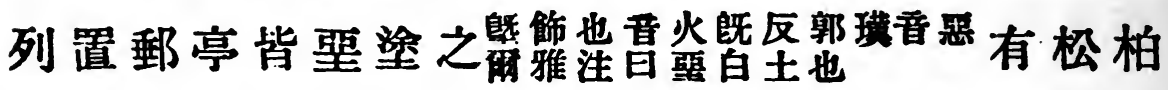
諸木百草人俗力田作多種樹䆛桑皆㽞頭而衣

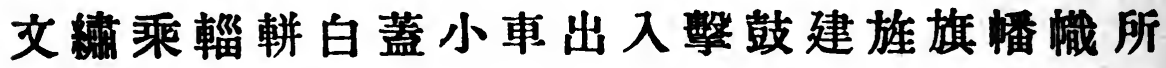
居城邑周圆百餘里城中有五宮相去各十里宮 室皆以水精第柱食器亦然其王日游一宮㯖事 五日而後徧常使一人持落隨王事人有言事者 即以書投整中王至宮發省理其柱直各有官曹 文書置三十六將皆會議國事其王無有常人皆 简立賢者國中农異及風雨不時軴噔而更立受 放者甘黜不怨其人民皆長大平正有類中國故 
謂之大秦士多金銀奇寶有夜光壁明月珠駭雉 康（抱朴子曰通天柈有白理如綎者以盛米置

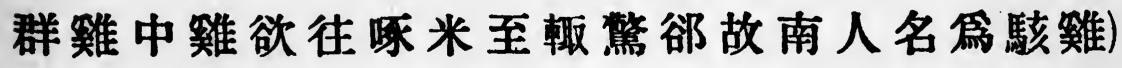

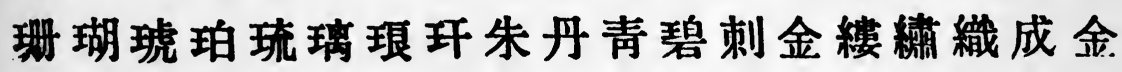
䋛蕆雜色棱作黃金染火浣布刃有細布或言水

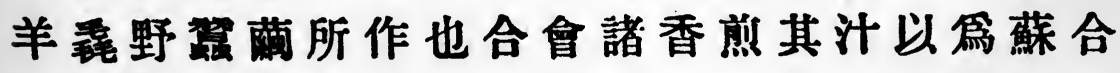
凡外國諸珍異皆出焉以金銀雼錢銀錢十當金 錢一興安息天竺交市於海中利有十陪其人質 直市無二價毫食常戝國用富皢隣國使到其界 首者乘驛芘王都至則給以金錢其王常欲通使 於漢而安息欲以漢緒綵興之交市故遮関不得 自達（閶五代反）至桓需延熹九年大秦王安敦 遗使自日南徽外献象牙柈角䞍琄始乃一通焉 其所表貢站転珍異疑傳者過焉或云其國西有 弱水流沙近西王母所居處幾於日所入也漢書 云從條支西行二百餘日近日所入則與今書異 矣前世漢使皆自鳥戈以還莫有至條支者又云 從安息陸道橈海北行出海西至大秦人鹿愺属 十里一亭三十里一置 (置驛也) 絡無盜賊寇整 
淌道多猛虎獅子遮害行旅不百餘人视兵器軙 第所食又言有飛橋數百里可渡海北諸國所生 奇異玉石諸物誘怪多不經故不記云（魚㐿魏 略日大秦國俗多奇幼口中出火自縳自解跳十 二丸巧妙異常)

(兒後漢書第八十八卷西域傳第七十八) (F)

大秦國一名黎鞬在西海之西其地東西南北各 數千里有城邑其城周回百餘里屋宇皆以珊瑚 篇梲栭琉璃篇牆壁水精孚柱礎其王有五宮其 宮相去各十里每旦於一宮聽事絡而復始若國 有焁異輙更立賢人放其舊王被放者亦不敢怨 有官曹簿領而文字㚙胡亦有白蓋小事旌旗之 属乃郵驛制置一如中州其人長大貌類中國人 而胡服其土多金玉蜚物明珠大貝有夜光壁該

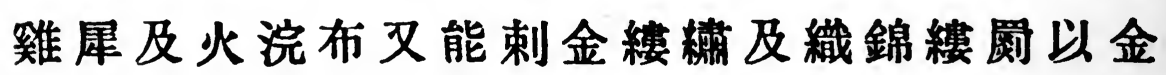
銀爲錢銀鈛十當金錢之一安息天竺人與之交 市於海中其利百陪鄰國使到者朝茼以金錢途 經大海海水城苦不可食商客往來皆三视 
是以至者稀少漢時都謢班超遣掾甘英使其國 入海船人日海中有思慕之物往者莫不悲懷若 漢使不戀父母妻子者可入英不能渡武爱大康 中其王遣使貢献.

(見晋書第九十七卷列傳第六十七) (G)

大秦國一名黎軒都安都城從條支西渡海曲一 萬里去代三萬九千四百里其海傍出猶渤海也 洏東西與渤海相望蓋自然之理地方六千里居 兩岸之間其地平正人居星布其王都城分爲五 城各方五里周六十里王居中城城置八臣以主 四方而王城亦置八臣分主四城若謀國事及四 方有不决者則四城之臣集議王所王自聽之然 後施行王三年一出觀風化人有寃枉詣王訴訟 者當方之臣小則讓责大則黜退令其擧賢人以 代之其人端正長大衣服車旅擬儀中國故外域 謂之大秦其土宜五款桑麻人務䆛田多琴琳珢 玕神龜白馬朱明陎夜光壁東南通交趾又水 道通谷州永昌郡多出異物大秦西海水之西有 
河河西南流河西有南北山山西有赤水西有白 玉山玉山西有西王母山玉䍃堂云從安息西界 䛻海曲亦至大秦四萬餘里於彼國觀日月星辰 無異中國而前史云條支西行百里日入處失之 遠矣.

（見魏書第一百二卷列傳第九十） (H)

挮菻國一名大秦在西海之上東南興波斯接地 方萬餘里列城四百邑居連展其宮于杜㯙多以 水精琉璃雼之有貴臣十三人共治國政常使一 人將囊隨王車百姓有事者即以書投落中王罯 宮省發理其柱直其王無常人簡賢者而立之國

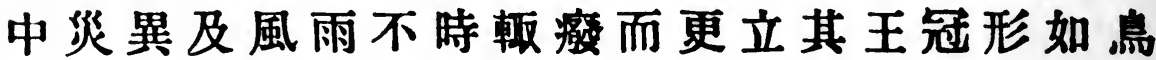

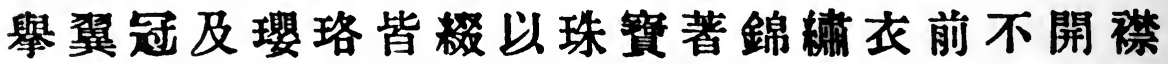
座金花伢有一鳥似鵝其毛綠色常在王邊倚枕 上座每進食有毒其鳥颙鳴其都城量石第之尤 絕高峻風有十萬餘戶南臨大海城東面有大門 其高二十餘丈自上及下飾以黃金光輝督爛連 曜數里自外至王室凡有大門三重別異害雕飾 
第二門之樓中馝一大金秤以金丸十二枚圆於 衡端以候日之十二時焉篇一金人其大如人立

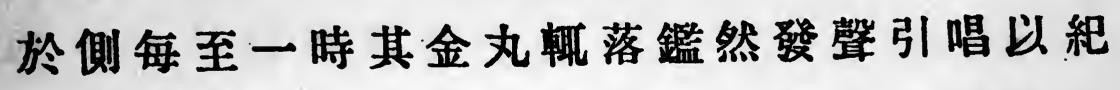
日時毫整無失其殿以瑟瑟爲柱黃金篇地象牙 篇門扇香木篇棟梁其俗無瓦擣白石篇末羅之 壁屋上其堅密光潤還如玉石至於盛暑之節人

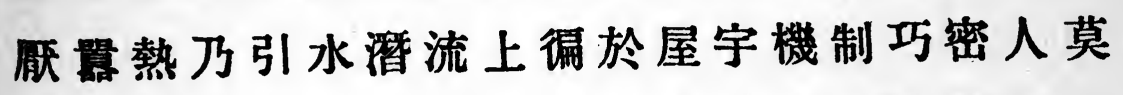
之知觀者惟聞屋上泉鳴俄見四篇飛溜称波如 瀑激氣成凉風其巧妙如此風俗男子剪琵披帔 而右祖婦人不開襟錦営頭巾家資滿億封以上: 伦有羊羔生於土中其國人候其欲萌乃筑牆以 院之防外獸所食也然其滕與地連割之則死唯 人著甲走馬及擊鼓以駭之其羔敬鳴而膦絕便

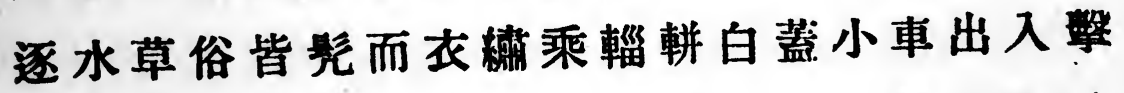
鼓建旅旗幡幟土多金銀奇寶有夜光壁明月珠

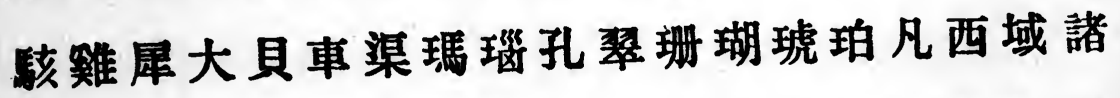
珍異多出其國隋焬严常將通拂菻竟不能致貞 覞十七年挮菻王波多力遭使献赤玻程金精 等物大宗降電答慰睗以校綺正自大食强盛 
渐陵諸國乃遣大將軍摩峨伐其都城因約爫和 好請每瓷輸之金帛逐臣䐂大食焉乾封二年造 使献底也伽大足元年復遣使采朝開元七年正 月其主遺吐火羅大首領献獅子羚羊各二不數 月又遺大德僧來朝貢。

(見舊唐書第一百九十八卷列傳第一百四十 八)

(I)

拂菻古大秦也居西海上一日海西國去京師四 萬里在苦西北直笑厥可薩部西濒海有逮散城 束南接波斯地方萬里城四百勝兵百萬十里一 亭三亭一置臣役小國數十以名通者日澤散日 䮡分澤散直東北不得其道里東度海二千里至 驉分國重石盆都城廣八十呈東門高二十丈釠 以黃金王宮有三襲門皆飾異寶中門中有金巨 稱一作金人立其端圆十二丸率時改一丸落以 瑟瑟篇殿杜水精琉璃営稆香木梁黃金篇地象 牙䦎有貴臣十二共治國王出一人絜囊以從有

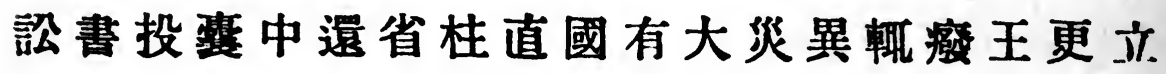




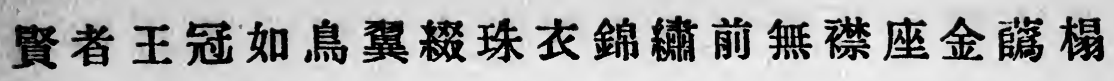
侧有鳥如鵝綠毛上食有毒暎鳴無陶瓦屋白石 壁屋堅潤如玉盛暑引水上流氣雼風男子剪琵

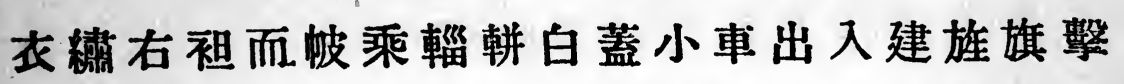
鼓婦人錦巾家頃億萬者篇上官俗喜酒嗜乾䚣 多幼人能發六千顔手営江湖口幡㿞擧足墮珠 玉有善醫能開腦出虫以愁目告士多金銀夜光 壁明月珠大貝車砤碼磂木難孔唯虎魄織水羊 毛営布日海西布海中有珊胡洲海人乘大舶䙢 鐵綱水底珊瑚初生磐石上白如菌一葴而黃三 葴赤枝格交錯高三四尺鐵發其根餐網舶上絞 而出之失時不取即腐西海有市留易不相見置 直物旁名鬼市有獸名賔大如狗搌惡而力北邑 有羊生土中蟀属地割必死俗介馬而走擊鼓以 第之羔睛絕即逐水草不能群貞䧽十七年王波 多力遗使献赤玻称綠金精下詔答梖大食稍疆 遣大將軍摩拽伐之拂菻約和逐臣屬乾封至大 足再朝献開元七年因吐火羅大酋献師子羚羊 自挮菻西南度碃二千里有國日磨鄰日老勃薩 
其人黑而性悍地瘴㾖無草木五呩飼馬以搞魚

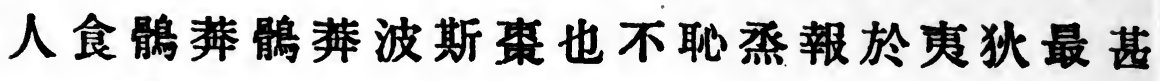
號日率其君七日一休不出納交易飲以穿夜. (見唐書第二百二十一卷下列傳第一百四十 六下) 


\section{BIBLIOGRAPHY}

Budge, E. A. W. The Historia Monastica of Thomas of Margâ. (The Book of Governors.) 2 vols. 1899.

Duchesne, Louis. Histoire ancienne de l'Eglise. Paris. 1908. Origines du culte Chrétien. Paris. 1898. (The English Edition of the same. London. S.P.C.K. 1912.)

Edmunds, A. J. Buddhist and Christian Gospels. (Edited and annotated by Dr. Anesaki.) Tokyo. 1905.

Eitel, E. J. Hand-book of Chinese Buddhism. Hong-Kong. 1888.

Etheridge, J. W. The Syrian Churches. London. 1846.

Gibbon, Edward. The History of the Decline and Fall of the Roman Empire. (Edited by J. B. Bury.) 7 vols. London. 1909-1914.

Giles, H. A. China and the Chinese. Columbia University Press, New York. 1902. The Civilization of China. London. 19II.

Hammond, C. E. Liturgies Eastern and Western. (Edited by F. E. Brightman.) Oxford. 1896.

Havret, Père Henri. La Stèle chrétienne de Si-ngan-fou. (Variétés Sinologiques, Nos. VII., XII., XX.) Shanghại. 1895-1902.

Heller, J. E. Das Nestorianische Denkmal in Singan-fu. Innsbruck. 1885.

Hirth, Frederick. China and the Roman Orient. Shanghai. 1885.

Holm, Dr. Frits. The Nestorian Monument. (Edited by Paul Carus.) Chicago. 1909.

Huc, Abbe. Christianity in China, Tartary, and Tibet. (Translated into English.) London. 1857, 1858.

Humboldt, Alex. v. Cosmos. 5 vols. (Translated into English.) London. 1849-1858.

Legge, James. The Nestorian Monument of Hsî-an-Fû. Oxford. 1888. Lloyd, Arthur. The Creed of Half Japan. London. IgII.

Milman, H. H. History of Latin Christianity. London. 1855.

Moule, A. C. The Christian Monument at Hsi-an-Fu. (Journal of the North-China Branch of the Royal Asiatic Society, Vol. XII.) Shanghai. 1910.

Nanjio, Bunyiu. Catalogue of the Chinese Translation of the Buddhist Tripitaka. Oxford. I883.

Pauthier, G. L'Inscription Syro-chinoise de Si-ngan-fou. Paris. 1858. 
Richard, Timothy. The Awakening of Faith, by Ashvagosha. Shanghai. 1907.

Schaff, P. History of the Christian Church. 7 vols. New York. I886-I910.

Stanley, A. P. Lectures on the History of the Eastern Church. London. 1883.

Williams, S. W. The Middle Kingdom. New York. 1883.

Wright, W. A Short History of the Syriac Literature. London. 1894. Wylie, Alexander. The Nestorian Tablet in Se-gan-Foo. Shanghai. 1854,1855 .

Yule, Sir Henry. Cathay and the Way Thither. 2 vols. London. 1866. New Ed., 4 vols., 1913-15. (Vols. I., II., III. of new edition are already out, and the last will appear soon.) The Book of Ser Marco Polo. (Edited by H. Cordier.) 2 vols. London. 1903. 


\section{INDEX}

A-FANG-KUNG, 3

A-lo-han, 133, 206, 257 ; Tablet in memory of, 206, 257-259, 271

A-lo-hê, 133, 188

A-lo-pên, 5 I, 8I, 82, 90, 94, I1 3, 153, $158,165-167,204-207,209,210$, 213, 257

Alopun. See A-LO-PEN

A-lo-ssŭ, 81, 82

"A-ssŭ-chü-li-yung ching," 69

Aaron, 177

Aba, Mar-Aba, 183

Abbot, 252

Abe-no-nakamaro, 236

Abhd-isho, I13, 176, 179

Abi, 176

Abidharma, 157

Abraham, 141, 168, 207, 224, 225 ; bar Dashandadh, 243 ; Mar, 107, II I

Abu-Becker, II6

Abulfeda, 248

Abu Musa ibn Musab, 243

Abu-nuh-al-Anbari, 243

Adam, 56, 7I-74, 92, III, II 4, I40, $148,154,162,175,178,186-188$, 194, 202, 203, 208, 214, 224, 228, $247,255,256$

Adiabene, 37

Adirsiah, 253

Aethiopia, 218

Afghanistan, 43

Afghans, 254

Africa, III ; N., 115

Ahmed Rasmi Effendi, 50

Aix-la-Chapelle, 238

Alcott, 144

Aléni, J., 2 I, 28

Alexander, of Alexandria, 99 ; the Great, 254

Alexandria, 39, 40, 99, 102, 104, I I5, 116; Patriarch of, 112

Alhazen, 117

Allan, W., I30

Aloha, 67, 75, I62
Alopano, 204

Alps, 238

Amaterasu Omikami, 126

America, 32

Amitabha, 121, 123, 125, 147-149, 15 I, 152, 155, I 58, I60; Doctrine, 190, 197, 216 ; meaning of, 122, 125 ; origin of doctrine, 149; -Sutra, 122

"Amitayur-dhyana-sutra," 133, 149, I51, 188, 197

Amitayus-sutropadesa, 13

Amogha-vajra, 127, 135-14I, 143, 232, 233, 252

Amsterdam, 29

An-hsi (Parthia), 45, 46, 219 ; (Province), $22 \mathrm{I}$

An-hsi-hsiang, 45

An-hsi-liu, 46

An-hui, 221

An Lu-shan, 23, 5 I, 226, 23 I

An-shih-kao, 46, I 22, 149

An-tu, 40, I81, 182

An-tun, 4I

Ananda, 138

Anamnesis, 145

Ancestor-worship, 113 , 133-1 36, 138 $140,143,158,160,201$

Anesaki, M., I18, 202

Ansoku, 45

Ansoku-ko, 45, 219

Antaxata, 4I

Antioch, 40-43, 97-99, 103-105, 115, 124, 132, 181-183, 190; Patriarch of, 91,112

Antoninus, M.A., 41, 42

Apollinarianism, 99

Apostles' Creed, 70

Arabia, Arab, 45, 51, 52, 105, 109, 11 5-1 1 7 $, 156,158,206$

"Arabian Nights," 5 I, 226

Aranyakah, 187

Archdeacon, I13, 175, 178, etc.

Arhan, 133 
Arhat, 120, 133, 188

Arians, 99

Armenia, 43, 109, 110

Armenian Christians, 6r

Arnobius, 110

Arohan, 207

Arsacide dynasty, 46

Arsakes, 46, 122, 149, 219

Art, 63 ; Hittite, 64

Arya-dasa, 24I

Asamgha, 130

Ascension, The, 195

Asceticism, Buddhist, 120, 121

Ashvaghosha, 120, 121, 147, 155, 216

Ashiki, 149

Asia, Central or Upper, 158, 206, 216, 232, 237, 251, etc. ; Buddhism in, I1 8 , $120-122,130,131$; Christianity in, 118,130

Asia Minor, 77

"Asiatic Society, Journal of China Branch of," 190, etc.

Assemani, J. S., 35, 110, 183, 204, 206, 207, 245, 254

Assyrian Church, passim

Aston, W. G., 125

Astronomy, Indian books on, 46

Asuka-oka, 145

Athanasius, 99, 124

Athens, 116,158

Aurelianus, 42

Aurungzeb, 254

Avalokita, 123

Avalokiteshvara, 123, 195

BAB-EL-MANDEB, 217

Babylon, 253

Babylonia, 40, 105, 206

Bachus, 176, 179

Bactria, 39, 44, 238, 253

Baghdad, 35, 51, 52, 106, 109, 182, 238, 243, 244

Bajazet, Sultan, 108

Balkh, 62, 110, 175, 238, 251, 253, 254

Bamian, 25I

Bandot, J., 137

Baptism, Buddhist, 137, 138, 141

Baptismal Hymn, Nestorian, 65-71, 115 ; translation, 66,67 ; text of, 272

Bardesanes, 44

Bashush, 243

Bartoli, D., 17, 29

Basil, 99
Beal, S., 55

Beards, 200

Behistan, rock of, $1 ; 155$

Benares, 119, 121

Beroe, 243

Beth-Abhe, 243

Beth Baghesh, 243

Beth Hale, 243

Bethlehem, 76, 77

Beth Sinaye, 186

Bethune-Baker, J. F., 11 I

Bible, 155, 157, 164, 165, 207-209

"Bibliotheca Orientalis," 35, 183, 245

Birthday, Festival on Emperor's, 86, 141, 142, 232-234

Bishops, 113, 176, 205, etc. ; Missionary, 252, etc. ; Nestorian Metropolitan, 109, I IO, II 3, etc.

Bishop, Mrs. I. B., 13

Bismarck, 208

Biwa, 146

Board, Beating of, 198

Bodhidharma, 147

Bodhiruchi, 13, 136, 147, 194

Bodhisattva, 121 , etc.

Bodleian Library, 72

Bokhara, 254

Bolor, $25 \mathrm{I}$

"Book of Changes," 187

Books, Buddhist, passim ; Chinese in Japan, 146 ; Nestorian in China, 68-71,-208, 209; rare Buddhist in Korea, I19; translation of Christian, 208, 209

"Books, New Catalogue of Buddhist," 72, 289

Bbrpus, 45

Boym, M., 29

Breviary, Malabar, I10 ; Roman, 137

Brahmans, 156

Bridgman, E. C., 29, 185

British Museum, 8 , 10, 30

Brittany, 144

Broomhall, M., 49

Buchus, 68

Buddha, 13, 73, 77, 120, 121, 123$125,133,138,150-152,178,188$, $195,217,241$, etc. ; bone of, 86

Buddhas, Cave of Thousand, 216, 232

Buddhism, 92, 114, 116, 132-134, 136, 138, 186, 193, 194, 205, 209, 238, etc. ; Chinese, 139, 144, 145, 158, etc.; difficult to compare 
with Christianity, 119; Hinayana, 65, etc. ; Indian, 118, 136, 139, 149 , etc. ; influence of Nestorians on Chinese, I18-16I; Japanese, $65,121,139,144-147,152,155$, 197, 198, 201, 219, etc. ; Mahayana or Northern, 86, 118 , I19, I 21 , 149 , etc. ; not in Fu-lin, 80 ; persecution of, 82, 85-90, 133, 134, 143, etc. ; relation to Christianity, 118-161; rise of, 87; Southern, $118,119,122,139,144,146,148$, 149, 156, etc. ; spread of, 134, 135, 140

"Buddhism, Biographical History of," 142, 233 ; "Handbook of Chinese," 138 ; "N. T. of Higher," I3I

Buddhist, Books, 65, I19, 133, etc. ; versions of, 137,149 ; Mahayana, 44,46 , etc. ; doctrine, 157 ; evidence of Nestorian Christianity, 7I-75; number of monasteries and of monks, 86-89, 91 ; ditto in Japan, 86 ; Sects, 119, 120, 126, 146, etc. ; sutras, 135, etc. ; Temples in Korea, 181; terms, 132, 217, 218, 254, etc. ; texts, 273

"Buddhist and Christian Gospels," I20

"Buddhist Catechism," 144

"Buddhist Scriptures, Catena of," 55

"Buddhist Sects, History of Twelve," 13

Buddhists, I, 12, 13, 74, 233, 234, 242 , etc. ; number of, 118 ; ditto in Japan, 146

Budge, E. A. W., 36, 186, 198, 244, 245

Bu-do, 45

Bun-mei, 177

Bun-tei, 177

Bunyan, J., 195

Bureau, Imperial ( $T^{\prime}$ 'ai-ch'ang-ssŭ), 252 , etc.

Burma, 118

"Bussetsu Amida kyo," I49, 150

"Bussetsu Muryo ju kyo," 149

But-lam, 76

But-lim (-lin), 76, 77

Butrum, 77

Byzantine Art, 63

Byzantium, 39
Caliph Al-Mahadi, 244

Caliph al-Rashid, 244

Cambridge, 44

Canton, 72

Capital, Eastern, 4 ; Western, 4, 5, etc.

Carthage, Bishop of, 1 I I

Carus, 42

"Cathay and the Way thither," 52, 90 , 1 10, 130, 200, 204, 248-250

Catholicos, 68, 132, 175, etc.

Celestine, 102

Celibacy, 153, etc.

Ceylon, 72, I18, 137

Chakravarti, 123

Chalcedon, 104 ; Council of, 9I

Chaldæa, 183

Chaldæans, 105

Ch'an sect, 126

Chandra-dasa, 24I

Chang Ch'ien, 39-4I

Chang Kêng-yü, 17, 20, 27, 95

Chang Kuang-chêng, 84

Chang-sun, 219

Chang-tê fư, 216

Ch'ang-an, $1-5,12,17,18,21,23,26$, $27,35,37,62,83-85,93,137,140$, $144,146,159,165,214,219,222$, 223, 228, 237, 239, 241, 248 ; hsien, 3 ; and see HSI-AN FU

"Ch'ang-an chih (Topography)," 4, 81,220 ; texts, 288, 289

"Ch'ang ming huank to ching," 68

Ch'ang shêng chên chüieh, 54

Chao (million), 129 ; and see CHAU

Chao-i-lang, 247

Chao-i-lang-ch'ien-hang, 57, 247

Chao-kuang Chiao, 48

Chao-tê, 177

Chao-t'i, 187

Charlemagne, 37, 238

Chau Ju-kua, 183

"Chau Ju-kua," 182, 183

Chavanres, E., 76, 190

Cheikho, L., 204

Chekiang, 20, 27, 57, 58, 96, 175 ; E., 58

Chên sect, 146, 219; and see SHINSHU

Chên-tan, 187

Chên-yen sect, 126, 131, 138; and see SHINGONSHU

Chêng-chou, 8 , 10

Chêng-kuan (period), 81, 88, 165, 166, 207-209 
"Chêng tsŭ t'ung," 22

Chêng-yüan (period), 85, 234

"Chêng yüan hsin ting Shih chiao mu lu," 71, 72, 289

Ch'êng-ch'i, 226

Ch'êng-hua (period), 7

Ch'êng-shih sect, 126

"Ch'êng-tsan Ching-t'u Fo nieh shou ching," I 49

Ch'êng-tu, 23I

Cherakhs, 250

Chi $(x), 132$

Chi, II

Chichintales, 90

Chi-chou, 221

Chi-ho, 168, 169, 229, 230

Chi-ku-setsu, 233

Chi-lieh, 75, 76, 168, 224, 225, 230, 290

Chi-nei, 248

Chi-tao, 54

Ch'i dynasty, 87 ; Prince, 203

"Ch'i chên ching," 70

Ch'i-lin ko, $25^{8}$

Ch'i-shan, 20

Ch'i-yang, 17, 95

"Ch'i yüan chên ching," 7

Chia-ching (period), 7

Chiang Chên, 84

Chiang $\cdot$ chou, 83

Chiang-liang-yeh-shê, 15 I

Chiang-nan, 222 ; E. \& W., 58

Chiao, 127

Ch'iao Lin, 84

Chien, 202

Chien, Mnt., 222

Chien-ch'un Gate, 259

Chien-chung (period), 35, 170, 174, 175, 234

Chien-nan, 222

Ch'ien-ch'iu chieh, 233

Ch'ien-chou, 84

Ch'ien-fo tung, 216, 232

Ch'ien-lung (period), 211

Ch'ien Ta-hsin (Mr.), 20, 59, 177, 245, 293, 296

Ch'ien-yen, 68

"Chih chieh ching," 69

Chih-chien, 179

Chih-i, 44

Chih-k'ai, 130

Chibli (Pechili), 44, 221

Chih-tê, 179

"Chih yüan an lo ching," 68

Chin dynasty, 87
Chin-ch'êng chün, 206, 257

Chin-kang-chih, 127, 135, 137

Chinkiang-fu, Churches at, 90

Chinnampo, 13

Chin-shêng ssŭ, 6, 7, 19

"Chin shih tsui pien" prohibited in Japan, 31

Chin-tan Chiao, 2, 48, 49, 53, 55-61, 91, 158, 160, 16I, 246, 256; Liturgy, 61 ; relation to Christianity, 53 sqg.

Ch'in-chou, 221

Ch'in dynasty, 3, 187, 221

China, passim; communication with W., 39-47 ; Metrop. See of, I09III ; N., 216 ; S., 132, 215

"China, and the Chinese," 45 ; "and the Roman Orient," 40, 76, 77 ; "Hist. of," 234, etc. ; "Illustrated" (Mon. Illustrata), 29 ; "Mission Handbook," 56 ; "u. die Chinesen," 49

Chindamani, 12

Chinese, Christians, 30, etc. ; Empire, 40, etc. ; Foreign words in, 44-46 ; Republic, 30

Ching, 127-129, 132, 183, 184, 186

Ching (or King), R., 6, 73

Ching-chao (-yin), 3

Ching-chên, 177

Ching Chiao, 127-132, etc.

"Ching chiao k'ao," 246, 293-295

Ching chia pei. See NESTORIAN MONUMENT

"Ching chiao pei wen chi shih k'ao chêng," 190, 245

"Ching chiao San Wei mêng tu tsan," 65-81, 272 ; and see BAPTISMAL HYMN

Ching-ching, 34, 36, 71-74, 92, 162, $184,186-188,194,214,224,228$, $232,246,247$

Ching-chou, 221

Ching-fu, 179

Ching-hsiang, 132

Ching Kang, 84

Ching-shih, 129

Ching-tê, 177

Ching-t'u, 195, etc, ; see Jodo, SuKHAVATI, etc. ; sect, 126

Ching-t'ung, 68, 178

Ching-yang, 208

Ching-yüan, 83

Ching-yün, 258 
Ch'ing-chou, 42

"Ch'ing i ching," 69

Chinghiz Khan, 90, 109, 253

Chiu-chiang, 58

Chorepiscopos, 62, 103, 114, 154, 162, $175,178,187,222,254,255$, etc.

Chou (Department), 25I, etc.

Chou dynasty or state, $3,59,87,166$, $186,210,211,214,215,223,239$; Duke of, 214 ; Eastern, 167, 223 ; King of, 3

Chou-chih, 16-27, 84, 85 ; poem by Lu Lun, 25 ; texts, $274-280$

"Chou-chih, On the completion of the new Banqueting Hall at," 23-25

Chou K'ü-fei, 182, 183

Chou-nan, 22, 249

Christ, 160, etc.

Christian, 132

"Christan Archæology and Art," 124

"Christian Art, Symbolism in," 190

"Christian Churches, History of," I00, I0I

"Christian Teaching of Coin Mottoes," 130

"Christianisme en Chine," etc., 95,

Christianity, Christians, passim; Assyrian (Nestorian or Syrian), I, $38,43,47,48,140-144,148,152$, 153, 155, 191, 192, etc. ; Chinese name for, 127-1 32; in China, 30, $38,39,73$, etc. ; difficulty of com: paring with Buddhism, I I9 ; early in China, I10; like Buddhism, 129,130 ; not mentioned in China 9th to 13 th cent., 90 ; influence of, 93, 94 ; Nestorian common under Mongols, 90 ; persecution of, 159 ; prohibition-boards, 29,32 ; relation to Buddhism, 118-161; relation to Islam, 50-52 ; sects, 201 ; spread of, $43,94,96$

"Christianity in China, Tartary and Tibet," 95, 97

"Christianity, Mission and Expansion of," 44

"Chronicles (Shih Chi)," 39, 45

Chryśostom, 99, 102

Chu (i.e. T'ien-chu), 17

Chu Tz'ǔ, 83-85

Chu-wa, 178

$\mathrm{Ch}^{\prime} \mathbf{u}, 129$
$C h h^{\prime} u, 185$

Ch'u Sui-liang, 57, 247

Chï-hsin, 78, 177

Chï Po-yü (or Yü), 59

Chü-lo, 259

Chü-lu, 68

Ch'ü-shên, 180

Ch'uan hua ching," 69

Chuang-tzŭ, 135

Chung, 189, 190

Chung-ho, 178

"Chung-hsü chên ching," 135

Chung kuo, 185, 186

Chung-li Ch uian, 54

Chung-Tsung, 82, 223, 224, 228

Ch'ung-ching, 176

Ch'ung-jên ssŭ, 7, 16

Ch'ung-shèng ssŭ, 6

Ch'ung-tê, 179

Church, The, passim; Assyrian or

Nestorian, 95, 106, 112 , etc. ;

Catholic, 143 ; Celtic, 144 ; Greek,

95, 112, 113 ; Head of, 175, 252 ;

Roman, 95, I I2, I1 3, I 44 ; Western, 112,114

Civilization, Ch'ang-an, I, 2, 92, 94, 95, 146, 159 ; Chinese, 1, I57, etc. ; Christian, 2 ; Græco-Roman, 157, 182; Greek, 115 ; Roman, I, 115 ; Western elements in Chinese, 117 , 155; Western introduced by Nestorians, $115-118$

Clarke, P., iI

Clement of Alexandria, 115

Cloud, on Nest. Mon., 14, 27 ; Flying, 14; Monastery and sect of Great, 220 ; White, 14 ; Sect of White, 48

Cochin-China, 28

Conduct, Eight Rules of, 194

Confucianism, Confucianists, 1, 92, 132, 134, 138, 139, 142, 143, 156, 158,234 ; join in Birthday Service, 86

Confucius, 39, 93, 156, 214

Constantine, 78, 177; the Great, 124, 132, 196

Constantinople, 76, 97-100, 102, 104, 106

Convents, Buddhist, 214, 220, etc. ; Nestorian, 81, 141, etc.

"Cosmos," 115

Cowley, 63

Cranganor, 28

Craze, La, 33 
Cremation, 134, 139, 144

Cromwell, O., 29

Cross, The, 70, 162, 164, 188, 196, 197 ; Doctrine of, 70 ; on Nest. Mon., 14, 27 ; Sign of, 113

"Cross, The Iron," 18, 306

Crystal, 240

Ctesiphon, 4I, 42

"Culte Chrétien, Origines du," 124, 145

Cyriacus, 179, 225, 230

Cyril, 102-105, III, I12

Cyzicus, IOI

DAIKON, 45

Dai Nichi Kyo, 127

Dai Seishi, 123

Danapati, 236

Daniel, 157

Danna, 44

Darius, 254

Darkness, 188

Dasa, 15, 172, 24I

Dasarhas, 24I

David, 68, 176 ; Metropolitan of China, I10, $111,186,187$

Dead, Prayers for, I65, 201, 202, 234

Demetrianus, 43

Dengyo Daishi, 37, 57, 126, 140

Dharma, 125

Dharmagupta, 136

Dharmakaya, 124, 125,201

Dharmaraksha, 136, I 38, 194

Dhyana, 125, 126 ; Bodhisattva, 125

Dhyani, 157; Buddha, 125

Diaz, E. (Jr.), 15, 17-19, 21, 229, 307

"Dictionary, Eng. - Chin.," 128 ; "K'anghsi," I 29

Diodorus, 99

Dioscorides, 117

Diptychs, 61, 65-70, 75, I 13, 143, 201 ; Syriac names on, 75, 78

"Doctrine of the Mean," 156

Dogs, Korean, 64

Donran, 13, 147

Doshaku, 13, 147

Dowling, I9I

Dragon's Beard, 168, 228, 229

Dschondisapur, 116

Dsiheber, II7

Ducange, 183

Duchesne, 91, I11, 112, 124, 145

Dunyn-Szpot, 260, 276

Durani, 254

Dynasties, The Three, 17 I, 239
Ê-FU-LIN, 70, 78

"Ê-fu-lin ching," 70

E ko, 201

E-ning. See I-NING

East, Children of the, 109 ; worship towards the, 198-200

"East Syrian Daily Offices," 13, 196

"Eastern Church," 132

Ebedjesu. See ABDH-IsHo

Ecbatana, 253

Ecgfrith, 130

Edessa, 42-44, 105, I1 15,158

Edict of $638,136,166,209-213$; text, 288

Edict of 745, 213 ; text, 288

Edict of $845,47,48,86-89$; text, 281,282

Edkins, J., 74

Edmunds, A. J., 120

Edrisi, 248 .

Edwin, 130

Egypt, 42, 77, 98, 105, I I4, I1 5, 124, 199

Ei-toku, 178

Eight, Cardinal Virtues, 192-194 ; Precepts, 193 ; Rules of Conduct, 194

Eitel, E. J., 12, 137, 138

Elias, 176, 178

Elijah, 70, 204

Eliya, Mar, I10, I 86

Elizabeth, Queen, 49, 50

Elnathan, 204

Eloah, 15

"Eloge des trois Majestés," etc., transl., 66, 67, 70. See BAPT. HYMN

Eloh, 188, 190

Eloha, 133

Elohim, 188

Embassies from Rome, 4I, 42

Emerson, W., 154

Emmanuel, 179

Emperor, Birthday Festival, 232-234, etc. ; Portraits of, 166, 168, 216 , 227-229; late of Japan, 20I ; The Yellow, 229

En-wa, 176

England, 130

Enoch, 78, 177

Ephesus, 102-105, 111 ; Council of, 102-104, 111 , I1 2

Ephraim, Ephrem, 70, 75, 76, 78, 80, $141,176,179,181,182,230,238$; of Elam, 37; of Gunde-Shabhor, 243, 244 
Episcopos, 132 ; and see BISHOP

"Essay on Man," 193

Etheridge, 206

Eudokia, 102

Euphrates, 39, 218

Euprepius, Convent of, 105

Europe, 38, 132

Evangelists, The Four, 68

FA-ChIEN, 237

Fa-chu, 1 32 ; cf. 167, 175

Fa-hsiang sect, 126

Fa-hsien, 42, 198

Fa-lu sect, 48

Fa-wang, 68-70

Fa-yüan, 178

Faith, Salvation by, 151, 216, etc.

Falcon, 46

Fan Yeh, 18

Fang Hsüan-ling, 165, 208

Fasts, 114,200

Favre, L., 183

fên-shển, 190

Fén-yang, 54, 171, 239

Fêng-chể, 179

Fêng-hsiang fu, 17

Fêng-shui, 3

Feng-t'ien, 83, 84, 237

Ferghana, 45, 25I

Fernandez, A., 28

Fetneh, 226

Firuz, Brothers of, 82, 106, 241

"Fo shuo A-mi-t"o ching," I 49

"Fo shuo kuan wu-liang-shou ching," 188

"Fo shuo Pao-t'ai ching," 193, 194

"Fo shuo Wu-liang-shou ching," I 49

"Fo tsu li tai t'ung tsai," 233

Football, 145

"Four Gates sutra," 70

Fu, 251

Fu-kien, 58, 222

Fu-lin, 40, 76-80, 18I-183 ; Mystery of, 76-80; same as Li-k'an or Tach'in, 76; = Bethlehem, 76, 77 ; $=$ Ephraim, 78, 79; = Polin, 76; = Rome, 77 ; = Syria, 77 ; described, 79; Greater and Little, 80 ; King of, 78,79 ; texts, $310-$ 320 ; Priest, $75,78,79,176$

Fu-p'ing hsien, 12

Fu-shou, 176

Fu-shui chên, 8

Eu-tsu-lin, 176 Fujiwara, Kanesane, I54 ; Sudatoshi,

Fukuju, 176

Fuku Kongo, 137

Funazoko, 195

GABRIEL, 94, 175, 180, 225, 252

Gandhara, 120, 130, 216 ; Council at, 133

Ganem, 226

"Garbha sutras," 193, 194

Gaul, 137

Gautama, I19, I20, 150

Genghis. See CHINGHiz

Genichi, 177

Genku, I 46-148, I53, I 54

Genran, 178

Genshin, 147, 177

Genso, 179

Gentoku, 179

George, 68, 69, 75, 14I, 176, 178, 205, 230, 243

Germany, 208

Getai, 44

Ghanta, 198

Gibbon, E., 29, 38, 52, 73, 90

Giesler, II I

Gikyo, 178

Gilan, 206

Giles, H. A., 44, 45

Gisai, 179

Giwa, 229

Giwargis, 205, 230 ; and see GEORGE

"Glossarium," etc., 183

Good Hope, C. of, 64

Goodness, Three kinds of, 151, 152

Gordon, Mrs., 32, I18, 131, 138

Gouvea, A. de, 17, 29

Government, Eight objects of, 170, 234-236; Grand scheme of, 235, 236

"Governors, Bopk of," 36, 37, I10, 186, 198, 206, 244

Grapes, 45

"Great Learning, The," 157

Great-Sun worship, 144

Great Wall, 39, $4 \mathrm{I}$

Greek, Art, 63; buckle in Far East, 63, 64 ; used by Nestorians, II5 ; words in Chinese, 45

Greeks, I17

Gur, 68, 259

Gyoga, 92

Gyogi Bosatsu, 32, 125, 136, 139

Gyori, 225 
HADRIAN, 4I

Hai-yen ward, 220

Han dynasty, 3, 40, 41, 59, 87, 167, 22I, 249 ; Eastern, 4, 22I ; Minor or $\mathrm{Shu}, 4$

"Han dynasty, History of," 181, 216 ; "History of After," 181, 182

"Han-shan-tzŭ chi," 135

Han T'ai-hua, 180

Han $Y \ddot{u}, 57,85,86$, 91

Hanan-Ishu, Henan-Isho, 35, 36, 69, 107, 175, 183, 242-245

Hang-chou, 17, 20, 26, 95

Hao, 219 ; Western, 168, 223

Harnack, A., 43, 44, 132

Hase (Hasi), 46

Hasitaka, 46

Havret, H., 17, 19, 30, 187, 191, 204, 246

Harun al-Rashid, 51, 226, 238

Hayton, 90

Hazza, 243

Heaven, Idea of, 156 ; Western, 122 , etc. ; worship of, 136

Hebrew words in Chinese, 45, 46, I 88, 189, I9 I

Hebrews, Epistle to, 197

Hedhai-yabh, 243

Heller, J. E., 30, 225, 245, 254, 255

Heri-Rud, 250

Herodotus, 218

Hierarchy, Court, 237

Himalayas, 119

Hinayana, 65, I19-123, 134, 139, 146, I48, 155 ; unlike Christianity, 120

Hindu Kush, 251

Hindus, $110,158,187$

Hirth, F., 40, 76, 77, 182

"Histoire de l'ancienne Eglise, 112

"Historical Magazine," 78

"History, Mirror of," I58, 159

Hittites, 63,64

"Hittites, The," 63, 64

Ho-chi, 14I, 176

Ho-kuang, 179

Ho-ming, 179

Ho-nan, 49, 53, 207, 221, 249 ; fu, 258,259

Ho-pei, 22 I

Ho-sa-yeh, 68

Ho-tung, 22 I

Hogen, 178

Hogg, C. F., 5I

Hokekyo, 130
Hoko, 179

Hokoku, 179

Holm, F. von, 9, 11, 30, 32

Honchi sui jaku, 136

Honen Shonin, 146, 148, 153, 154

Honeysuckle design, 63

Honganji, 5 I

Hongwanji, 197

Horses, Arab, 45

Hosamba, 245

Hosea, 68

Hoshin, 179

Hoshu, 12

Hotatsu, 176

Hotoke, 65

"Hou Han Shu," 181, 182

Hsi-an-ch'ien, 255

Hsi-an chou, 255, 256

Hsi-an fu, 2-1 2, 15-23, 26-28, 37, $38,4 \mathrm{I}, 47,5 \mathrm{I}, 54,55,6 \mathrm{I}, 65,75$, $79,85,92,95,96,114,126,129$, $130,137,140,145,161,183,186$, $187,207,214,221,222,225,237$, $248,249,255,256$; described, 5 , 6 ; history of, 3,4 ; size of, 4

Hsi-an-tso, 255

Hsi fang ching $t^{t} u, 15 I$

Hsi kua, 45

Hsi-la-ssŭ, 250

Hsi-ming monastery, 72, 237

Hsingan. See HSI-AN FU

Hsi wang $m u, 218$

"Hsi-yü-chi," 238, 253

Hsia dynasty, 87, 239

Hsiang-chu, 254

Hsien, $25 \mathrm{I}$

Hsien (King of Chou), 3

Hsien-ching, 257

Hsien-fêng (period), 180

Hsien-jên, 218

Hsien-nan-yeh, 68

H sien-ning, 3, 6

Hsien-t'ien (period), 167,223

Hsien-Tsung, 86 .

Hsien-yang, 3

Hsien-yu ssŭ (monastery), 84, 8;

$\mathrm{H}$ sin Wên-fang, 60

Hsing-an, chou, 256 ; fu, 255, 256

Hsing-ch'ing Palace, 141, 169, 230

Hsing-t'ung, 175, 255

Hsü Kuang-ch'í (Paul), 17, 18, 96, 97, 306

Hsiian, 185

Hsüan-chên, 177

"Hsüan-i ching," 69 
Hsüan-lan, 178

Hsuian-tê, 78, 179

Hsüan-tsang, $79,135,139,149,238$, 253 ; "Travels of," 33

Hsüan-Tsung, 58, 130, 137, 140, 141, $168,173,208,213,216,221,223$, $224,226-228,230-232,239,288$

"Hsüan yüan chih pên ching," 68

Hu language, 72

Hu-nan, 222

Hu-pei, 221

"Hua hu ching," 215

Hua-yang, 23, 26

Hua-yen sect, 126

Huai-i, 237, 253

Huai-nan, 221

Huan-shun, 177

Huan-Ti (Han), 4I

Huang-ho, 31

Huang $P^{\prime} u, 62$

Huc, Abbé, 30, 95-97, 189, 192, 196, 202, 209, $211,228,232,240,242$, 246

"Hui-ch'ao's Visit to the Five Indies," 80

Hui-ho, 220

Hui-ming, 176

Hui-tao-chên-jên (or -shih), 60

Hui-t'ung, 176

Hui-yüan, 215

Hulaku Khan, 109

Hulme, 190

Humboldt, A. von, I15, 117

"Hun yüan ching," 69

Huns, 39, 77

I-CHI, 179

"I-ching," 187

I-fêng (period), 81

I-ho-chi-ssŭ, 68

"I-li-yeh ching," 70

"I-li-yüeh-ssǔ ching," 69

l-ning ward, $16,8 \mathrm{I}, 166,209-2 \mathrm{I}$, $213,220,241$

I-p'u-lan ssŭ, 181

I-ssŭ, 26, 170, 17 I, 236-240

"I-tsê-lü ching," 70

Ibreez, 63

Ihai, 65,143

Image Teaching, 87 .

Images, I32; used by Nestorians, 113

Immortals, The, 8, 54, 167, 218

Incense, 45, 219 ; -wood, 62, 63, 65

India, $14,39,44,65,74,77,79$, 109,
$110,116,146,198,216,217,253$;

Central, 42, 72; North, 43, 72,

137 ; North-west, 118 , 121 ; South,

131 ; West, 121

Indian Ocean, 217

Inscriptions, Book of, prohibited in Japan, 3I

"Iron Cross, The," 18, 306

Isa, 243, 244

Isaac, $176,178,180 ;$ i.e. I-ssŭ (q.v.), 236-240; the Jew, 238; the Patriarch, 37; Nestorian Patriarch, 106

Isé, 125

Isho-yahbh IlI., 36, 37, 52, 107, 243, 244

Ishvara, 123

Islam, see MOHAMmedanism ; True man of, 60

"Islam in China," 49

Italians, 115,117

Italy, 137, 144

Ito, Dr., 63

Itsukushima shrine, 239

Iyetsuma, 29

Izadsafas, 177

JABALLAHA, 204, 206, 207, and see YAHBH-ALLAHA

Jacob, 178, 179, 231 ; Mar, 36, 242, 244; the Patriarch, 37

Japan, II, 29, 3I-33, 37, 45, 46, $61-65,86,91,92,118$, I19, $136-$ I40, $145^{-1} 47$, 156, 159-161, 198 , 20I, 202, 2I9, 220, 224-226, 23I, $237,239,241,252$; influenced by Nestorians, 93 ; national movement in, 145 ; visited by Persians, 61,62

Japanese, 77 ; foreign words in, 4446,93

Jaquet, 76

Javan, I IO

Jên, 191

Jên'hui, 177

Jerusalem, 132

Jesu-ameh, 177

Jesudad, 177, 179

Jesus, 160

Jesus, Mercy of, 175

Jewish Inscription, 207, 224, 225

Jews, 50

Jigaku, 92

Jih, 128, 183, 184

Jih-chin, 176 
Jinkei, 177

Jnanagupta, 130

Jo-shui, 218

Job, 177

Jodo, 195, cf. Ching-t' $u$, etc. ; sect, 146,147 , etc.

"Jodo-ron," 13

Joel, 176

John, 176-180 ; Bishop, 176, 255 ; Patr. of Antioch, 103, 104 ; St., 68

John, Gospel of St., 200

Joseph, son of Mari, 37 ; of Merv, 243,244

Ju-lai, 123, 133

Judæa, 40, 182, 191, 207

Jui-Tsung, 223, 224, 226, 228, 237

Julien, S., 33

Jundo, 181

Jung, Jung-t'ung, 197

Justin Martyr, 4I

Justinian, 116

K'AI-FÊNG FU, 207, 225

K'ai-yüan (period), 88, 225

"K'ai-yüan mu-lu," 122

Kalayashas, 151, 188

Kammu, I30

Kan-chou, Kanchau, 90

Kan-su, 49, 206, 221, 231, 257

Kan Ying, 41

Kandai, 222, 248, 249

Kanishka, I2I, 133

"K'ang-hsi Dictionary," 129

Kanjun, 177

Kappa ( $), 132$

Kao Li-shih, 141, 168, 227

Kao-Tsu, 3, 203, 228

Kao-Tsung, 94, 153, 167, 173, 219, 223, 228, 257

Kapilavastu, 119,218

Kapisa, 72, 148

Kardagh, 206

Kash-kul, 70

Kashmir, 140, 186, 194

Kasuga shrine, 239

Katherine the Great, 93

Kechien Kwango, 138

Keifuku, 179

Keimei, 176

Keishin, 177

Keitoku, 177

Keitsu, 176, 178

Kêng Wei, 25

Kennaya, 68
Kenyu, 177

Keum-chyong, 13

Khanbalig, Khambling, 1 10

Khorassan, 250, 251, 252

Khotan, 43, 131, 148, 198, 216

Khurdistan, 116

Kiang-nan, 57, 58 ; and see ChiangNAN

Kiang-si, 54, 58, 96, 222

Kiang-su, 58, 222

Kin Tan Kiao. See CHIN-TAN CHIAO

King, 186

King Kiao. See Ching Chiao

King Tsing. See ChING-CHING

Kiogin, 180

Kircher, A., 17, 29

Kiyoshin, 177

Knowledge, 200

Ko Shu-han, 240

Kobo Daishi, 11, 12, 32, 37, 75, 91, $92,126,136,139,140,142,144$, 214,239

Kohana, 119

"Kojiki," 37, 6r

Kokei, 176

Kondo Seisai, 31

Kong-t'ien, 248

Kongobuji, II

Korea, 13, 45, 46, 64, 90, I I8, 119 , .18I

"Korea," 13

Koreans, 77

Korean script, 63

$K^{\prime}$ ou, 184,185

Kosai, 178

Kosei, 179

Kotoku, 180

Koya, Mount, I1, 12, 32

Kuan-chung, 18, 221

Kuan-nei, 25, 221, 222, 248, 249

Kuan-tzŭ-tsai, 123

Kuan-yin, 55, 123, 195

Kuang-chêng, 179

Kuang-chi, 178

Kuang-ch'ing, 176

Kuang-lu-ta-fu, 170, 237

Kuang-ping Prince, 23I

Kuang-si, 222

Kuang-tê, 180, 225

Kuang-tung, 222

Kublai Khan, 145, 146

Kumarajiva, 136, 149, 194

Kumbet, 64

Kumbhira, 12, 13 
Kumdan, 25, 73, 94, 154, 175, 178, $222,248,249,252,255,256$

Kuo-i, 225

Kuo Tzŭ-i, 26, 54, 17 I, 231, 237, 239, 240

Kusumapura, 218

Kuwabara, Dr., 6, 7, 32

Kyoto, 37, 51, 64, 118, 197, 214

Kyuretsu, 225

LAI-WEI, 177

Laity, 242

"Lalla Rookh," 250

Lao-tzŭ, 156, I92, 195, 202, 212,215 , $216,219,224,233$

"Lao-tzŭ hsi shêng hua hu ching," 215

Languages of Churches, 115

"Last Essays," 50

Latin, used by Nestorians, 115

"Latin Christianity, Hist. of," III

Law, Buddhist, 125

Leek, 45

Legge, J., 29, 34-36, 127, 156, 184, $185,189,190,193,194,197,203$, $209,211,217,222,228,232,233$, 240-242, 245, 247

Leiju, 177

Leitoku, 177

Léon Li. See LI CHIH-TS'AO

Li-chien, 177

Li Chih-ts'ao (Léon), 17, 19, 20, 27, 95-97, 302

Li-ch'üan ward, 8I, 241

Li-k'an, 40, 76, I81, 182

Li-kien, 182

Li Kuang-pi, 240

Li-mi, 62

Li-mi-i, 62

Li-pên, 178

Li Shih-min, 203

Li Tuan, 25

Li Tê-yü, or Yü, 47 : Letter of, 89 , 285,286

" $\mathrm{Li}$ Yü (Tê.yü), Complete Works of, 89

Li Yüan, 203, 204, 208

Li-yung, 179

Liang dynasty, 87

Liang-chou, 221, 222

"Liber Synodalis," 43

"Lieh hsien ch'üan chuan," 60

Lieh-tzŭ, 135

Life, Eternal (Amitabha), 122, 125, 148,160
Light, 130, 188: Author of, 126 ; Boundless (Amitabha), 122, 125, 148 ; Cross of, 196 ; of the World, 131

Lin Lai-chai, 16

Lin.ssŭ, 208

Ling (i.e. Ling -yin), 17

Ling Chih-chê, 60

Ling-chou, 231

Ling-nan, 222

Ling-pao, 175

Ling.p'ai, 65, 143

Ling-shou, 78, 177

Ling-tê, 177 ; Palace, 234

Ling-wu, 141, 169, 231

Lions, 46,64

Lisbon, 29

Liturgy, Gallican, I24 ; Nestorian, 145

Liu Pang, 3

Liu T'i-shu, 60

Liu Tsung-yüan, 22, 26, 85, 9r, 94, 218, 276, 278

Lloyd, A., 118

Lo Chên-yü, 65

Lo-han, 14I, 168, 207, 224, 225

Lo-po, 45

Lo-yang, or Lo, 3, 122, 147, 223. 249

Lobscheid, 128

Lochana, 125

Logos, The, 99-101, 215

Lokarakcha, I49

London, 252

Lotus on Nestorian Monument, 14

"Lotus-Gospel, etc., The," 131

Louvre, The, ro

Love, Incarnation of, 126

Lowrie, W., 124

Lu-chia, 68

Lu-ho-ning-chü-sha, 67

Lu Lun, 25, 280

Lii sect, 126

Liu Hsiu-yen, 34, 37, 56-59, 6I, 74, $175,184,245-247,256$; identified with Lii Yen, 56-6I

"Lü Tsu ch'üan shu," 60, 6r

Lü Yen, 54-6r, 246, 247, 256; Lives of, 60 ; miracles of, 61

Lucius Verus, 4I

Luke, 68, 75, 177

Lunar race, 123

Lung, Mount, 22 I

Lung-yu, 221

Luther, M., 154 
MA-Lo (MAR), 46

Ma-lo-fu, 183

Macleane, A. J., 13

Madhyamika, 121

Madhyimayana, 120

Madrid, 4

Magadha, 77, 217, 237, 238

Magi, Adoration of, 63

Mahabidjna Djnana Bhikshu, 123

Mahadad, 68, 69 ; Goushnasaf, 176

Mahasamghika, 24 I

Mahasthanaprapta, I23

Mahayana, 86, I19-1 21, 131, 134, 139, 144, 146, 149, 155, 156, 198, 215

"Maha Vairochana sutra," 124

"Mahométanisme en Chine," $5 \mathrm{I}$, 220

Maitreya, 130

Makhikha, I08, 109

Malabar Breviary and Church, 110

Manchu dynasty, 7, 26, 27, 55

Manchuria, 53, 77, 90

Manichean, Temple, 220 ; writings, 65

Manicheans, 232, etc.

"Manichéen, Un Traité," etc., I90

Manjusri, 72

Mar, 46, etc. ; Sergius, 13, etc.

Maran Zekha, 198, 199

Marga, 186, 194

Margoliouth, Prof., 254

Mark, St., 68

Marriage of Priests, I45-155, 160

Martini, M., 15

Maru, Maro (Mar), 46 ; (Merv), 243, 244, 250, 251

Mary, The Virgin, 50, 99-102, I 12

Masudi, 248

Matai, 177

Matsumoto, M., I Io

Matthew, 75,177 ; St., 68 ; a vegetarian, 115

Maudgalyayana, 138

Mawaralnahr, 25I

Maximian, 104

Mecca, 116

Medes, I I0

Medicine, Schools of, 116

Meiitsu, 179

Meiji, 32

Melchites, 52

Meliapor, 14, 27

Memento, The, 65, I45

Memnon, Archbishop, 103, 104
Mercy, Vessel of, 195

Merv, See of, 251, 252; and see MARU

Meshihadad, 176

Mesopotamia, 39, 4I, 43, 109, 114, 116, 218

Messiah, The, $15,40,46,67,68,70$, 73-75, 152, 160, 163, 190, 191, 195 , 232, 234 ; Religion of, 130 ; Buddhist, I 30 , etc.

"Messiah, Desire of the Nations," I3 I

Metropolitan Bishop of China, 186, 187

Metropolitan Sees, Nestorian, 249

Metropolitan Museum, New York, I I

Mi-li, 62

Mi-lề fo, 160

Mi-mi-kiao, 55

Mi-shih-ho (Messiah), I9I

"Mi-shih-ho tzŭ tsai t'ien ti ching," 70

Michael, I76

Michel, Dr. See Yang ChI-YeN

Middle Kingdom, 162, 185,186

"Middle Kingdom, The," 186

Milis, 62, I 14, 142, I 54, 175

Milman, H. H., I I I

Min-yen, 68

Ming dynasty, 7, 26, 27, 59, 81, 221

Ming-i, 179

Ming-t'ai, 68, 177

Ming- $T i, 86$

Miroku, 12, 160

Missionaries, Buddhist, 72, 140, etc. ; Christian, 159, etc.; Jesuit, 26; Nestorian, I, I2, 13, 47, 54, 64, 72, 107, 109, 126, 131-133,148, 157, 159-16r, 216, 217, 227, 228, etc.; Persian, 255; relation of to Buddhists, etc., 92

Mitama, 65

Mo (Mar), 46

Mo-chü-ssŭ, 68

Mo-mu-chi-ssŭ, 68

Mo-sa-chi-ssŭ, 68

"Mo-sa-chi-ssŭ ching," 70

Moabite Stone, 10, 155

Mohammed, 50, 52, I16, 220

Mohammedan, -anism, -ans, I, 2, 7, $14,47-53,60,89,91,116,158,160$, I6I, 220, 224, 232, 233 ; Christians absorbed by, 91, 109; persecution 
of, 82, 85-90; population, 49, etc. ; writings, 65

Monasteries, destruction, 86-88, etc. ; 281-287; Head of, 252, 253 ; names of, 132, 230, 231; Nestorian, 213, $214,219,220,226$, etc. ; number of Nestorian, 240, 241 ; Persian, 213, etc.; Ta-ch'in, 213, 214, 219, 220 , etc. ; White Horse, 253 ; and see BUDDHIST

Mongolia, 53

Mongol dynasty, 90

Mongols, 77

Monks, Assyrian or Nestorian, 132, 208, 209, 214, etc. ; Buddhist, 125, 127 , etc. ; number of foreign, 88, 91 ; as soldiers, 237

Monophysites, 9I, 99

Monte Cassino, 116

Monte Corvino, John of, 90

Moon, worship of, 136

Moore, T., 250

Mopsuestia, Bishop of, 99

Morality, Chinese, 157

Moses, 68, 70, 176 ; the Armenian, 249

Mosques, 220

Mostasin, 109

Mosul, 243

Mou-shih, 68

"Mou-shih fa wang ching," 70

Moule, A. C., 20-22, 49, I89-19I, 193, 197, 203, 204, 210, 21 I, 228, 232, 241, 242, 247

Mu-chia-lio, 138

Mu-hu-fu, 47, 88

Mu-yü, 198

Mukan, I10, 186

Murad, Khan, 49, 50 ; of Kurduz, 254

Murakami, S., 134

Murddhabhichikta, I37

"Musulmans Chinois, Recherches sur les," 49

Müller, Max, 50, 93

Mykenæ, 64

NA-NING-I, 68

Nadir Shah, 254

Nagarjuna, 120, 121, 131, I47, I55, 216

Naisho, 179

Nakamura, 32

Nakatomi-no-asomi, 62

Nama Amitabha, I48, 149
"Nan-hua chên ching," 135

Nanjio, Bunyo, 13, 74, 149, 15 I

Nara, 62, 63, 145, 239

Nativity, The, 232, 234

Navarra, 49

Neander, 98, 111

Nei-chêng, 179

Nepal, II8

Nestorian, Books, language of, 115 ; Church, doctrines of, 99-101, 1 IIII 5 ; rise of, 97-II I; Churches in China, 90, etc. ; Fasts, 114 ; Inscription, passim ; text of, 260-270 ; translation of, 162-180 ; Liturgy, 61 ; Missionaries, 1,12 , 13 , etc., and see Misstonaries; Patriarchs, 5 I, 52, 106, 109, etc. ; list of, 106I08; Physicians, 62, 116, 117 ; Priest, titles of, 94, etc. ; Writings, 65, etc.

"Nestorian Inscription, Considerations on the," 246 ; "Critical Study of the," $18,30,245$

-Nestorian Monument, 56, 57, 62, 7I, 73-75, 89, 91, 94, 107, III, 124, $126,133,140-143,153-155,159$, 174, 175, 180, 234, 236, 252, 255, etc. ; Buddhist terms on, 74, 132, 217, 218, etc.; Chinese authors upon, 291-306; Conclusion of Introduction to, $155-16 \mathrm{r}$; Copies of, 10-12; Erection of, 35, 8I, etc. ; Described by Semedo, 27 ; Em. Diaz upon, 307-309; Effect of Discovery, 95-97 ; First known in Japan, 31 ; Historical value of, I, etc.; How found, 2I, 22; Japanese ignorance of, 3I, 32 ; Not in early "Stone and Metal Collections," 81, 82 ; Material of, 12 ; Persian word on, 15 ; Position of, 3, 6-9 ; Quotations on, 15 ; Removal of, 6-9 ; Replica of in Japan, II, 32; in New York, II ; Rubbing of, 17 ; Sanskrit on, 15 ; Size of, 12 ; Study of in the East, 30-32 ; Syriac on, 1 5, 28-30, $35,75,76,78,175-180,230,238$, 248 , etc., 260, 265-270 ; Versions of, 28-30, 34, 35, 162-180 ; When buried, 81-92; When found, 1921; Where found, 15-19; Where first erected, 22-26

"Nestorian Monument in China, The," 35 ; "of Hsi-an fu," I84; 
"On the Genuineness of the," 34

Nestorians, passim; causes of their failure, 159; chief merit of, 157 ; Chinese name of, 127-132 ; fate of early, $48 \mathrm{sqg.} \mathrm{;} \mathrm{influence} \mathrm{of,} 156$; on Buddhism, $118-161$; introduce civilization, 52, $115-118$; persecution of, 82, 85-90; vegetarians, 114

Nestorius, 97-106, $111,112,183$

Neumann, 30, 33, 248

New Testament, Syrian Canon of, 196

New York, 10, 11

Nichiren, 139, 146

Nieh-p'an Sect, 126

Nien, 229

Nien Ch'ang, 142, 233

Nien-ssŭ shêng (24 Sages), 68, 163, I9I

Nijo Castle, 214

Nimoksha, 120

Nineveh, 244, 253

Ning, King of, 226, 230

Ning-hsia, 23I

Ning-kuo, Prince of, 14I, 168

Ning-shu, 175, 242

"Ning-ssŭ ching," 69

"Ning yeh tun ching," 69

Nirmanakaya, 125, 195

Nirvana, 121, 126, etc.

"Nirvana sutra," 44

Nisibis, 105, 109

Nisshin, 176

Noah, 177

Normans, 137

Northern Region, 239, etc.

Northumbria, 130

Noyes, H. V., 49

O-BON-MATSURI, 140

Odoric, 90

Old Testament, 163, 191

Ollone, d', 49

Olopan, -pen, -pun. Sce A-LO-PEN

Okakura, Y., II

Okuno-in, 12

One-stroke-freedom, 185

Ono-no-imoko, 140

Orders, Nestorian, I13, I14, 193

Origen, 99

"Origines du Culte Chrétien," 91, 124

Osrhœene, 43

Otsuki, 44

Ou-yang Hsün, 57, 133, 247

Oxford, 6

Oxus, 40, 251

Pa-Kua Chiao, 48

Pai-lien Chiao, 48

Pai-yün Chiao, 48

Palestine, 39, 182

Palmyra, 42

Pamphylia, 103

Pan Ch'ao, 41

Pan-ku, 181

P'an-na-mi, 76, 225, 290

"Pao-hsin fa wang ching," 70

Pao-kuo, 179

Pao-ling, 178

Pao-lu, 68

"Pao-lu fa wang ching," 69

"Pao ming ching," 69

Pao-ta, 176

Papas, 162, 187, 224, 255, 260

"Paramita sutra, Six," I86, 194

Paramitas, Six, 151

Parthia, 39, 41, 44-46

Parthian, fruit, 46 ; incense, 45,219

Pataliputra, 218

Patriarch, 79, 97-100, 102-104, 106, 181-183, etc. ; Buddhist, 137, 252, etc. ; Nestorian, 51, 52, II4, 175, 186, 238, 242, etc. ; hereditary after 1557,115 ; list of, 106-108

Patricius, 183

Paul, 68, 69, 75, I78; Hsü (see HsÜ KUANG-CH'I), St., I57, I58, 216

Pauthier, G., 30, 34, 76, 90, I30, 204, 207, 24I, 245, 248, 249

Pearl, 12-14

Pechili, 44, 96. See CHIH-LI

Pei-lin, 6, 8

Peking, 6, 8, 65 ; Metrop. See of, rio Pelliot, P., 61, 65, 66, 68, 70, 71, 75, $78,80,115,190,207,208,215,216$, 272

Pên, 185

P'ên-ch'êng, 58

P'êng Yen, 84

Persecution of, Buddhists, 133, 134, 143 ; the third, 89 ; Christians, 159, etc. ; Foreign Faiths, 82, 83, 85-90; Nestorians, 109, 116

Persia , 39, 42-44, 46, 52, 76, 79, 80, 9I, 105, 109, 110, 114-116, 130, $158,189,213,225,241,244,245$, 250, 251, etc.

Persian, Persians, 98, 153, 163, 202, 
225, etc.; Chief, 206, 257, 258 ; tablet in memory of, $27 \mathrm{I}$; Costume, 63 ; Hawk, 46 ; in Japan, 61, 62 ; Monastery, 81, 213, etc. ; Physicians, 142 ; Priests, 72, etc. ; Religion, 130, etc.; Words in China, 45,46

Peter, 177 ; Disciple of Mar Timothy, III

Pethion, Mar, 243

Phillips, G., 78

Phrin, 182

Phrygia, 64

Phrygian caps, 63

Phuses, 178

Physicians, Nestorian, 62, i16, I17 ; Persian, 142

"Pi ê ch'i ching," 70

Pi-lu-ssŭ, 24I; and see F1RUZ

Pien-liang, 4

Pill of Immortality, 53 ; Sect of, see Chin-tan Chiao

Ping-yang, 13, 18r

P'ing-wang, 226

P'ing-yang, 55

Po-jo, 135

Po-ssŭ, 46

Po-to-li, 78, 79, 18 I, 183; = Patriarch, 79.

P'o-li, 240

Polin, 76

Polo, Marco, 90, 108, 253 ; "Travels of," 254

Polycarp, 4I

Pomegranate, 46

Pope, A., 192, 213

Poro, 178

Post-towns, Number of, 5 ; inscription on wall of, $23,276,277$

Praise-sutra, 65, etc.

Prajna, 72-75, 92, 135, 140, 148, 186, 194 ; known to Kobo, 75

חрdбov, 45

"Pratimoksha sutra," 120

Precepts, 200, 201 ; Eight, 193

Precious Mountain, 167, 217

Priesthood, Head of the, 255

Priests, Buddhist, 200, etc. ; marriage of, $145-155,160$; Nestorian, 148, $200,236,238$, etc.

Proclus, 101

"Prodromus Coptus," 29

Provinces, The Ten, 221, 222

Psalm cxix. quoted, I 3

Ptolemy, II7, 249
Pu-cheng Ward, 82, 24I

Pu-k'ung-chin-kang, 127, 135, 137

P'u-chi, 159, 178

P'u-chou fu, 54

P'u-hsien, 137

P'u-lun, 14I, 168, 230

$P^{\prime} u-t$ tao, 45

Pure Land. See Sukhavati

"Pure-land Sutra," 13, etc.

Purgatory, i 13, I39, 140

Pushi, 178

Pyramids, The, 16r

Quakers, 192

"Question of Ta-ts'in," etc., 78

Quietists, 192

R INITIAL, 77, 205

Rabban, 204, 205, 21 I, 257

Radish, 45

Rai-i, 177

Rajagriha, 217, 238 ; Little, 238

'Pd $\phi \eta, 45$.

Ratnaghiri, 217

Ratnamati, 217

Real Presence, The, 113

Reformation, The, 143

Rei-hai, 65, 143

Reinaud, 248

"Relations," ete, 248

Religions, Harmonizing of, 14. 136 sqq.

Renaudot, E., 248

Republic, Chinese, 30

Resurrection, The, 196; Hymn of, 199, 200

Ricci, M., 18, 28

Richard, T., 53, 56, 1 1 8, 131

Richi, 218

Riken, 177

Rinsai Sect, 146

Rippon, 178

Riyo, 179

Rockhill, W. W., 182

Roman, Empire, 40, 41, 76, 157, 182, 207 ; Military Engines, 137

"Roman Empire, Decline and Fall of," 38,52

Rome, 28, 29, 38, 4I-43, 77, 106, 137

Rosetta Stone, I, 10, 155

Roumania, 110

Royal Residence, City of, 17 I, 237. 238

Ruha-dekudsa, 67

"Ruins of Desert Cathay," 232 
Rupa, 201

Russia, 93, 205 ; Trans-Caspian, 250

Rustam of Henaitha, 243

Ryobu Shinto, 136, 239

SA-LA-HA-HSI, 250

Sabrisho, 175, 177

Sage, 202, 203

Sages, Twenty-four, 68, 163, I9I

Sahesvaradja, 123

Saikyo, 5

Saints, Festival of All, 136, 137 ; Names of, 68

Sakyamuni, or Shakyamuni, 7, 72, $93,125,130,132,138,147,151$, 216,218

Sakya-putriya-sramana, 73

Sakyas, 119

Salerno, 116

Salisbury, E. E., 33, 34

Salvation, by Faith, Goal of, Self., 120

Samadhi, 194

Samarkand, 90, I09, 110

Sambhogakaya, 124, 125

Samgha, 125, 138

Samghapala, 149

Samgharama, 72

Samghavarman, 149

Samponodo, 241

Samson, 178

Samyak sambuddha, 133

San chi ching, 69

San-lun Sect, 126

San-pao-nu, 24I

"San Wei (mêng tu) tsan ching," 70 ; transl., 66, 67, 272

San-yüan, 15-17

San'a, II I

Santhran Basilica, 124

Sanskrit, 44, 72, 75, 92, 1 22, 24I, etc.

Saracens, 137 ; and see MонаммеDANS

Saragh, 94, 175, 222, 248-250, 252

Sarakhs, 249

S'astras, imported, 137

Satan, 15,46

"Sat-paramita sutra," 72, I86, 194

Sayce, A. H., 63, 64

Schaff, 100, 101

Schlegel, G., 241

Science, physical, I17

Scriptures, 132 , etc.

Sea, Coral or Red, 167,217

Secret Societies, 48, 49, 53
Sects, Buddhist, 126, etc.

Sees, List of Nest. Metrop., 109, 110

Sejistan, $25 \mathrm{I}$

Seleucia (-Ctesiphon), 41, 106, 110, II 5, 244 ; Council at, 106, 153

Semedo, A., 14, 17, 19, 27-29, 95

Se.ngan. See HSI-AN :

Sêng, 132

Seoul, I3

Sepulchre, Priest of the, 176

Serakhs, 250, 252

Seres, I 10, 249

Sergius, of Maallethaya, 243; Mar, $68,70,75,90,177-179,255$

Seric, 249

Sha-chou, 6I, 65, 7I, 208, 215,272

Shahrakhs, 250

"Shan k'o lü ching," 69

Shan-nan, 221

Shan-si, 44, 53, 54, 96, 22 I

Shan-tao, 147, 148, 152, 153, 219

Shan-tso, 256

Shan-tung, 53, 96, 22 I

Shan-wu-wei, 127,135

Shang dynasty, 239

Shang-chu-kuo, 206, 257

Shanghai, 77, 118

Shang-tê, 205

Shang-tso, 254

Shang-tu, 3, 256

Shê-ti-ko, 46

Shedek, 46

Shên-lung, 82

Shên-shên, 178

Shén-si, 8, 2 I, 27, 44, 49, 53, 22 I, 255 , 256

Sheng, 187, 188, 191, 203

Shêng-hsien Chiao, 49

Shêng-jèn, 246

Shêng-li, 167, 222, 223

Shiang-thsua, 178, 254-256

Shilh (Lion), 46

"Shih-chi," I8I, etc.

"Shih-ching," 128

"Shih-li-hai ching," 69

Shih-lun Sect, 126

Shih Ssŭ-ming, 23

Shih Tao, 22 I

Shih-tsun, 132

Shiiken, 179

Shin Sect, Shin-shu, 12, 146, 197, 198, 201

Shingon Sect, -shu, I1, 12, 138, 142, 146, 201 
Shinran, 139, 146-148, 152-154, 197, 219 ; his predecessors, 147

Shin-shin, 178

Shinto, 125, 136, 201 ; Number of priests and shrines, 86

"Shinto the Way of the Gods," 125

Shir (Lion), 46

Shiratori, K., 40, 77, 78, 205

Shitoku, 179

Shomu, 125, 220, 24I

"Shosan Jodo Bustu Setsuju kyo," 149

Shotoku, i77

Shou-i, 178

Shoubhalmaran, 179

"Shu lio ching," 69

Shuitsu, 178

Shun-yang-kung, 256

Shun Yang-tsze, 54, 55

Shutoku, 179.

Si-an. See HSI-AN

Siam, II 8

Siddartha, 119

Si-gan, or Si-ngan. See HSI-AN

Eikúa, 45

Silas, 68

Simeon, 68, 176, 178, 179; Metropolitan of Persia, 244

Simonians, 105

Sinæ, 249 ; Metrop. See of, 109

Sinan Pasha, 50

Sisinnius, 97

Siurhia, 249

Slaves, 88, 94, 103

Smyrna, 4I

So-lo, 68

Socrates, 98

Sodo Sect, 146

Solomon, 180 ; of Al-Hadithah, 243

Soltania, Archbishop of, 90

Soul, Survival of the, 201

Souls, Festival of departed, 136-140, $143,144,155,160$

Southern Sea, Islands of, 72

Sozomen, quoted, 43

Sphatika, 15, 17 I, 240

Sphsaph, 243

"Spring and Autumn," 39

Sravasti, 218

Ssŭ, 132, 187, 214

Ssŭ-chu, 132

Ssŭ-ch'uan, 53, 222 ; Chiao, 48

Ssŭ-ma Ch'ien, 39, 45, I8I

Ssŭ-ma Kuang, 158

"Ssŭ-mén ching," 223
Ssŭ-shêng, 223

Ssŭ-shih-ts'an-chün, 57, 247

Stanley, A. P., 132

Stein, M. A., 51, 63, 148, 216, 232, 245

"Stèle Chrétienne de Si-ngan fou," 246

Sthavira, 255

Su-chou, Suchau, 90

Su Tan, 59

Su Tsung, 137, 141, 169, 17 1, 173, 23I, 232, 239

Su Tzŭ-tan, 59

Subhak'arasimha, 127, I35, 143

"Suddharmapundarika sutra," 130; Versions, I36

Suddhodana, II9

Sugawara-no-michizane, 140

Sui dynasty, 4, 134, 181, 21 5, 25 I

Suikwa, 45

Sukei, 176

Sukhavati, I 23, 147, I49, I 5 I, I 52

"Sukhauati Vyuha," I 49, I 50, I 5 I, I 97

Sumantrabhadra, 137

Sun Yat-sen, 30

Sun, 128, 150, 152, etc. ; -goddess, 125, 126; Horn of, 228, 229; on Nest. Monument, I3I ; Region in the, 250 ; worship of the, 136

Sunday, 202

Sun-religion, 48 ; The Great, 127

Sung dynasty, 4, 59, 81, 156, 158, I60, 221 ; Liu, 87

Sung Ching, 208

Sung Min-ch'iu, 81, 82, 220, etc.

Sutras, passim; imported, 137

Svara, 123

Syria, 42-44, 64, 72, 73, 77, 79, 98, 105, 1 10, I15, $116,132,182,191$, 207, 210,211

Syriac, 232, etc. ; Alphabet, 63 ; Language, I1 5 ; Names, 68-70, 175-180, 204, 206; Script, 5I ; Terms, 188,189 , I91 ; in Japan, 46 "Syriac, Church, The," 206 ; "Literature, Short History of," 36, 243

Syrian Bishops, 103, I04, etc.

Sżechuan. See SsƯ-CH'UAN

TA-CH'IN, 39-42, 47, 76-78, 81, 85, $88,141,162,163,165-168,181-183$, 19I, 207, 209, 210, 213, 216, 217 , 229, 230, etc.; 310-320 ; Coins, 40 ; Emperor, 83, 84 ; Monastery, 72, $73,81,162,166,213,214,219$, 
231 ; Parchment, 40; Rebellion, 82-85

"Ta Ch'ing I-t'ung-chih," 256

Ta-jih Chiao, 125, 127, 129-131

"Ta-jih Ching," 124

Ta-kuang-chih-san-tsang, 137

Ta-shih-chih, 123

Ta-shih-chu, 236

Ta-so, 24I, 242

"Ta T'ang lu tien," 57, 247

Ta-tê, 132, 205

Ta-ts'in. See TA-CH'IN

Ta-yün Ssŭ, 220

Tachibana, Z., 51, 63, 72, 148, 216

Tadjik, 80

Tai-Tsung, 137, 141, 142, 169, 174, 232, 233, 239

T'ai-ch'ang Ssŭ, 252

T'ai-chi, 223

T'ai Chou, 37, 57, 58, 175, 245, 247 ; fu, 58

T'ai.ho, 179

T'ai-Tsung, $5 \mathrm{I}, 8 \mathrm{I}, 88,165,203,204$, 207-209, 212, 214-216, 220-222, $224,227,228,24 I, 25$ I

T'ai-yang Chiao, 48

Taiwa, 179

Takakusu, J., 32, 7I, 74

Tama, 12

Tamerlane. See TIMUR

T'ang dynasty, or Land of, 2, 4, 5, I 5, 18, 30, 32-35, 46, 51 , 57, 58, 6I, $75,77,92-94,116,134-136$, 145 , $148,156,158,166,172,173,175$, 181, 184, 200, 203, 206-208, 210, $211,214,215,223-225,228,229$, 236, 238-240, 242, 245-248, 251 , $253,255,257,276$

"T'ang, History of," 78 ; "Six Codes of," 57,247

T'ang Chang, 62

" $T$ 'ang ching chiao pei sung chêng ch'üan," 229

"T'ang hui yao," 2 I I, 288

"T'ang Shu," 78

"T'ang ts'ai tzŭ ch'uan," 60

Tangut, 90, 110

Tao, 60, 202, 203, 212, 215, 224

Tao-an, 215

Tao-ch'o, 147, 152, 219

"Tao tê ching," 192, 21 2, 224, 233

Taoism, 92, 132, 188, 192, 202, 205, 212, 215 , etc.

Taoist, Taoists, I, 53, I34, 138, 139,
$143,156-158,167,219,234,254$, etc.

Tarsa, 24I

Tarsus, 99

Tartars, 77, 253 ; Christian, 90

Tashkand, 251

Tathagata, 123, 133, 149

Tê-chien, 180

Tê-hua, 58

Tê-Tsung, 72-74, 83-85, 232, 234, 239

Tehuristan, 175

Tejen, 250

Tencho-setsu, 233, 234

Tendai. See T'IEN-T'AI

Tenduc, 90

Tennyson, A., 195

Terauchi, 119

Testudo, 237

Theodore of Mopsuestia, 99, I00, 104

Theodosius II., 98, 102

Theophilus, 99, 102, 124, 190

Theotokos, 99, 100, 112

Thian shan, 90

Thiersant, D. de, $5 \mathrm{I}, 220$

Thomas, of Kashar, 243 ; of Marga, 36,186 ; St., 95, 110 ; Christians of St., 28 ; Tomb of St., 14, 27

Thorns, Crown of, 155

Three, Dynasties, 87 ; Gates, 195 ; Kingdoms, 4

"Three-sphere sutra," 69

Ti-chiu chieh, 233

Tiao-chih, 39

Tibet, $118,137,258$

T'ien-ch'ang chieh, 233, 234

T'ien-ch'i, 18

T'ien-pao, I41, 168, 227, 229

"Tien-pao-tsang ching," 69

$T^{\prime}$ ien shan, 90

T'ien-t'ai, 92 ; Sect, 126, 130, 131, 146 ; Mount, 37, 57, 126

Tigris, 39, 105,218

Timothy, Mar, 36, 37, 107, 111 , 186, $187,206,238,243,244$

Timur, 48, 52, 106, 108, 109

To-hui, 68

"To-hui shêng wang ching," 69

Tokhara, 122, 138

Tokharestan, 80

Tokuken, 180

Tokyo, 40, 62; 63, 71, 77, 82, 118, 257

"Tokyo Asahi Shimbun," 202

Toleration, Religious, 212,213 
Tonsure, 200

"T'oung-pao," 71, 76

Tower, 124

Transmigration, 121

Transubstantiation, 113

Trigault, N., 15-17, 19, 21, 28

Trikaya, 124, 125, 196

Trinity, Buddhist, 123-125; Doctrine of, 148 ; False dactrine of, 50 ; The Holy, 67, 190

Tripitaka, Chinese, 7I, 135 ; Catalogue of, 74

Tripitaka Bhadanta, 137

Triratna-dasa, 24I

Trividha Dvara, 195

Tsai, 229

Tsao-ho, 19, 22

"Ts'ao-shu tzŭ kao," 59

Ts'ên-wên, 68

Tsing, 186

Tsou Ching-chäng, 16

Tsun-ching, 65

Tsung (Emperor), I 33

Tsung Ch'u-k'o, 82

Tsushima Channel, 45

Tu Ju-hui, 208

Tuan Fang, 257

Tun-huang, 65, 216, 232

Tung Pin, 54

Tung Ch'ang, 59

Tung Ch'i-ch'ang, 59

"T'ung chên ching," 69

"T'ung hsüan chên ching," 135

Turkestan, 43, 48, 237, 251

Turki, 232

Turks, 77, 244, 248

Turris ambulatoria, 237

Tus, 251

"Tsú chih t'ung chien," I 58, I 59, 234

Tzŭ-fei tao yüan, 256

Tzŭ-mu Chiao, 48

"Tz'ǔ li po ching," 70

UIGURS, 51, 52, 60, 72, 106, 109, 220, 231, 232, 237, 240 ; Christians, 90 ; Script, 5.I, 232

Ullambana, 136, 138-140

"Ullambana sutra," I38

Uno, T., 9

Ural-Altaic tribes, 77

Urum, 77

Urumtsi, 90

Uyeno Library, or Museum, 62, 82, 89,257

Uzumasa, 64
VAIDACHI, I51, 752

Vairochana, 124-127, 130, 131, 136, $144,155,160$

"Vairuchana sutra," 129

Vajra Bodhi, 127, 135, 137, 143

Valentinus, 102

Vasubandha, 147

Vidjnana, 200

Vinaya, 126

Virya, 194

Visitor, 187

Voltaire, 33

WAGIS, I4I

Wah Abi Kobsha, 51, 220

Wakichi, 176

Wamyo, 179

"Wan hsing t'ung p'u," 60

Wang Ch'ang, 31, 8I, 299

Wang Hung, 83

Wang Hung-hao, 15; and see WANG, PhILIP

Wang Mang, 3

Wang, Philip, 15, 16, 95

Wang-shê ch'êng, 237

Wang Shih-chên, 60

Wang:yang Tzŭ, 54

Water-melon, 45

Way, The, 202, 203, 212, 215, 224

Weak Waters, 167,218

Wei, 203

Wei, dynasty, 4, 59, 87, 167 ; northern, 208 ; 'River, 6; 19, 22, 73

"Wei, History of," 182, 216

Wei-nan, 22I

Wei-p'ai, 65, I43

"Wei Shu," 182, 216

Week, 202

Wên-chêng, 177

Wên-chung, 135

Wên-ming, 177

Wên-shun, 178

"Western Heaven, Lao-tzŭ's ascent to," 215 ; “Travels to;" 155

"Western Lands, Records of," I67, 216

Western, Paradise, 123, 147, 149, 155, 215 ; Regions, 39, 40, 42, 65 , 158, 231; Sea, 218

“Western World, Records of," 79, 238, 253

White Foreigners, 39

White Lily (Lotus) Sect, 48, 57, 21 5, 216

Williams, S. W., 186, 239 
Wood, Striking of, 197, 198

Wooden Fish, 198

World, Saviour of (Buddhist), 144, 148,150

"World-healers, The," 131, 138

World-honoured, 132

Wright, W., 36, 243-245

Wrum, 77

Wu, Emperors, 133 ; Empress, 167, 219, 220, 222-224 ; 227, 253 ; King, 223

Wu-lin, 180

"Wu sha na ching," 70

Wu-Ti, 4I

Wu.Tsung, 47, 48, 52, 82, 83, 86, 89, $90,28 \mathrm{I}, 285$

Wu Tzŭ-pi, 180

Wu.wei Chiao, 48

Wylie, A., 29, 34, 127, 189, 190, 193, 196, 202, 210, $211,228,232,240$, 242, 245, 247

Xavier, St. F., 140

YABHALLAHA, 204, 206, 207 ; III., $52,106,108,109$

Yaguma, 178

Yaksamba, 245

Yamagachi, 140

Yaman, III

Yang Chi-yen (Michel), 97

Yang-chou, 23, 26, 221, 222 ; Churches at, 90

Yang Hsiang-fu. See Y. Jung-chih "Yang hsin lu," 59

Yang Hsiung, 129

Yang Jung-chih, 30, 190, 193, 194, 245

Yang Kuei-fei, 226

Yang-Ti, 181, 251

Yangtzekiang, 222

Yao Ch'ung, 208

Yao Ling-yen, 83

Yao-lun, 176

Yao-sên-wên, 46, 175, 245

Yao-yüian, 177

Yao-yüeh, 176

Yarkand, 90

Yaso, 160

Yedo, 31

Yeh, 216
Yeh-chü-mo, 178

Yeh-hu, 23I

Yeh-li, I75, 225, 252

Yellow River, 3, 6, 122

$Y e n, 242$

Yen (State), 129

Yeh-ho, 176

Yen-hsi, 4I

Yesbuzid, 62, 73, I14, 154, 175, 255

Yesumband, 46, 238

Yin dynasty, 87

Yin and Yang, 54, 188, 189

Ying-hsiu, 178

Ying-tê, 178

Yoetsu, 176

Yogacharya, 137, 139

Yogen, 177

Yorin, 176

Yule, H., 76, 90 , I10, 130, 200, 204, 248-25 I, 254

Yung-chou, 3, 221

Yung-hsing, 22 I

Yü-chou, 221

Yü-han-nan, 68

Yü-lan-pên, 136

Yüan dynasty, 221

Yüan-chao, 72, 73

Yüan-ho, 85

Yüan Hsiu, 84

Yüan-i, 177

"Yüan ling ching," 69

Yüan-tsung, 179

Yüieh-chih, 44

Yüeh-tung, 222

Yün-fang Hsien-shêng, 54

Yün-luan, 147

Yün-nan, 90

Yün-t'ai-ko, 258

ZACHARIAS, 69, 179

Zariaspa, 253

Zendo, 13,147

Zeno, 105, 116

Zenobia, 42

Zhinastan, 162, 187, 255

Zimmermann, J., 130

Zinai, 199

Zoroaster, 253

Zoroastrians, I, I14 ; Persecution of, 82, 85-90; Temple of, 82

Zubaidah, 244 



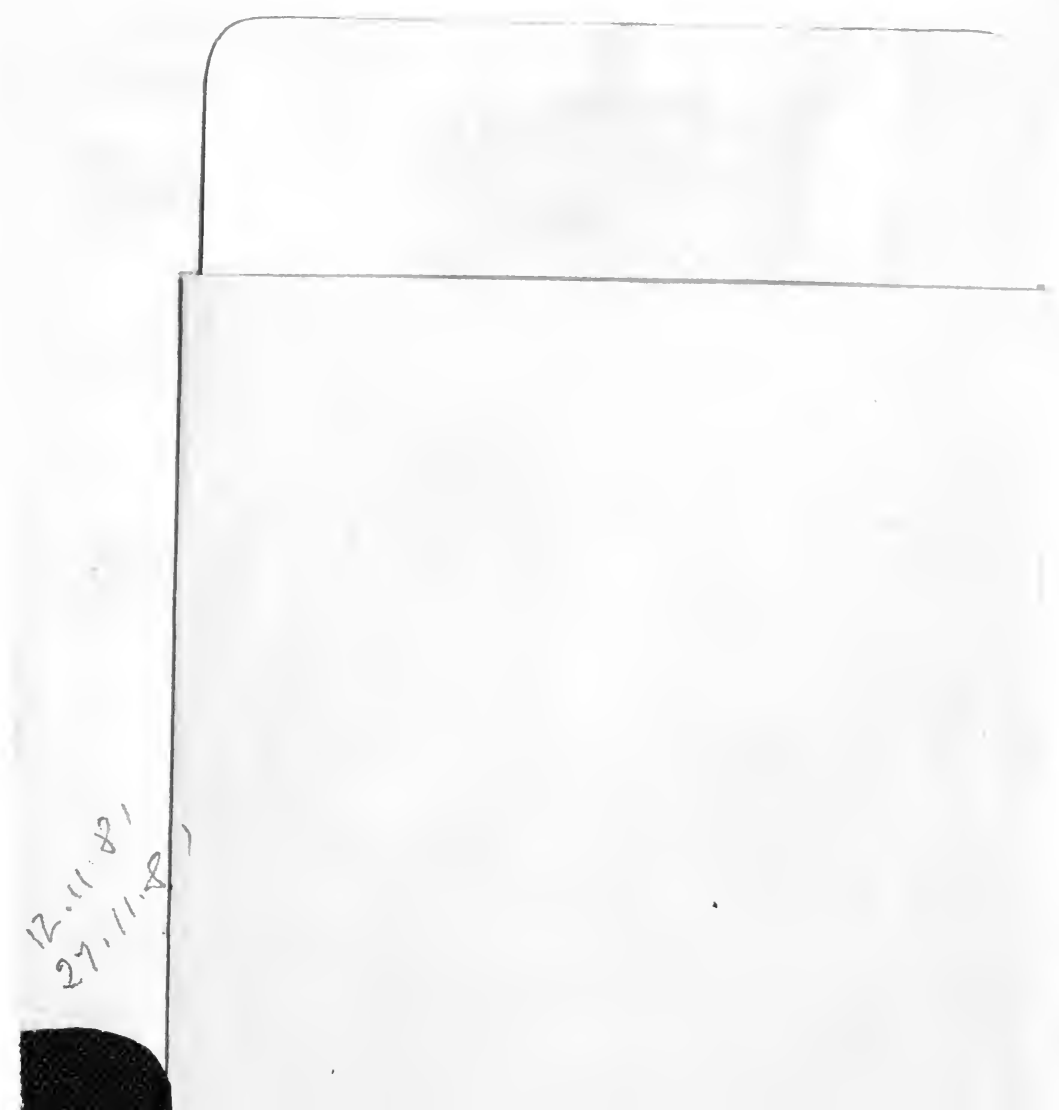




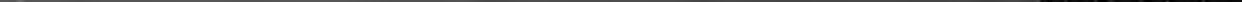

